Portland State University

PDXScholar

Dissertations and Theses

Dissertations and Theses

Summer 8-1-2016

\title{
Groundwater-Surface Water Interactions near Mosier, Oregon
}

Cullen Brandon Jones

Portland State University

Follow this and additional works at: https://pdxscholar.library.pdx.edu/open_access_etds

Part of the Geology Commons, and the Water Resource Management Commons Let us know how access to this document benefits you.

Recommended Citation

Jones, Cullen Brandon, "Groundwater-Surface Water Interactions near Mosier, Oregon" (2016).

Dissertations and Theses. Paper 3414.

https://doi.org/10.15760/etd.5312

This Thesis is brought to you for free and open access. It has been accepted for inclusion in Dissertations and Theses by an authorized administrator of PDXScholar. Please contact us if we can make this document more accessible: pdxscholar@pdx.edu. 
Groundwater-Surface Water Interactions near Mosier, Oregon

by

Cullen Brandon Jones

A thesis submitted in partial fulfillment of the requirements for the degree of

Master of Science

in

Geology

Thesis Committee:

Robert B. Perkins, Chair

Michael L. Cummings

Kenneth E. Lite, Jr.

Portland State University

2016 


\begin{abstract}
The town of Mosier, Oregon, is located near the east, dry end of the Columbia River Gorge, and the local area is known for cherry orchards that rely heavily on groundwater for irrigation. The CRBG groundwater system in Mosier has experienced groundwater declines of up to 60 meters due to over-pumping and or commingling. Declining groundwater levels have led to concerns over the sustainability of the resource, as it is the principle water source for irrigation and domestic use. Despite numerous previous studies of groundwater flow in CRBG aquifers here and elsewhere in the Columbia River basin, an aspect that has received relatively little attention is the interaction between groundwater and surface waters at locations where interflow zones are intersected by the surface waters.

The objective of my research is to investigate how CRBG interflow zone exposures in Mosier Creek may be controlling groundwater elevations in the area. The methods used include: (1) geochemical analysis of well cuttings and detailed geologic mapping along area streams to identify interflow zones of individual CRBG flows, (2) analysis of stream discharge data and groundwater elevation data to confirm exchange of groundwater and surface waters, and (3) collection and analyses of 31 water samples from area wells, streams, and springs, to determine if waters from individual CRBG aquifers can be hydrochemically identified and to further constrain understanding of surface and groundwater interactions.
\end{abstract}


My study confirms that the general elevation of the Pomona Member and Basalt of Lolo interflow zone creek exposure is coincident with the elevation where a change in slope of the decline trend in 2004 is seen in Mosier area well hydrographs. Furthermore, the results of stream discharge data indicated a close connection between drawdown from groundwater pumping during irrigation season and groundwater - surface water interaction. At the time of drawdown in the upper-most CRBG aquifer (Pomona), the stream transitions from gaining to losing water into the groundwater system.

Elemental chemistry data indicates the Frenchman Springs Sentinel Gap aquifer waters are the most evolved waters in this study. Stable isotopic data reinforced this determination as the Sentinel Gap waters are the lightest, or most negative, with regard to $\delta D$ and $\delta^{18} 0$. Sentinel Gap samples were more depleted than other aquifer samples by 4.38 to $6.89 \%$ for $\delta D$ and 0.39 to $0.59 \%$ for $\delta^{18} 0$. The results of the general chemistry and isotope data reveal a more evolved chemical signature in lower watershed groundwater versus a less evolved signature for waters from wells located higher up on the Columbia Hills anticline. This was interpreted to be the result of the major structural features in the area providing for a more regional pathway of recharge in lower watershed groundwaters, versus a more local source of recharge for upper watershed groundwaters. There was also a pronounced commingled signature in the elemental ratios of lower watershed 
aquifer waters. The suspected mechanism of recharge to lower watershed wells is through younger Cascadian deposits upslope from the local watershed.

The findings of this study reveal the importance of a detailed understanding of CRBG stratigraphy and its relation to surface waters, especially for other areas within the Yakima Fold Belt or Oregon and Washington. Studies that do not consider the influence that individual CRBG flows can have on groundwater - surface water interactions, and the groundwater system as a whole, run the risk of improperly assessing the groundwater resource for a region. 


\section{Acknowledgements}

I should begin by thanking the many citizens of Mosier, Oregon, who kindly allowed access to their property for geologic mapping and water sampling.

A special thank you goes to Ken Lite, Oregon Water Resources Department, whose dedication and knowledge of the geology and groundwater system near Mosier, Oregon, is unsurpassed. This project would not have been completed without his guidance and expertise. I would also like to thank my thesis committee; Dr. Ben Perkins, Dr. Michael Cummings, and Ken Lite, for their encouragement and guidance throughout the writing process. A special thanks to Dr. Perkins for his patience, first and foremost, and his scientific writing acumen, and thoughtful and knowledgeable revisions.

A would like to thank Jason McClaughry, Eastern Oregon Regional Geologist for the Oregon Department of Geology and Mineral Industries (DOGAMI), for allowing me to work for him on the Hood River Geologic Mapping project. Having the opportunity to learn from him, and Thomas Wiley, in the field, greatly enhanced the geologic mapping conducted for this project. Additionally, I would like to thank Bill Burns (DOGAMI). My overall geologic knowledge and GIS skills were improved greatly by working for him at DOGAMI.

Thank you to my family for their support, especially to my Mother, who always encouraged me and believed that I could complete this project. And finally, I 
most want to thank my significant other, Averie McCauley, without her love, support, and supreme editing skills, this project would not have seen completion. 


\section{Table of Contents}

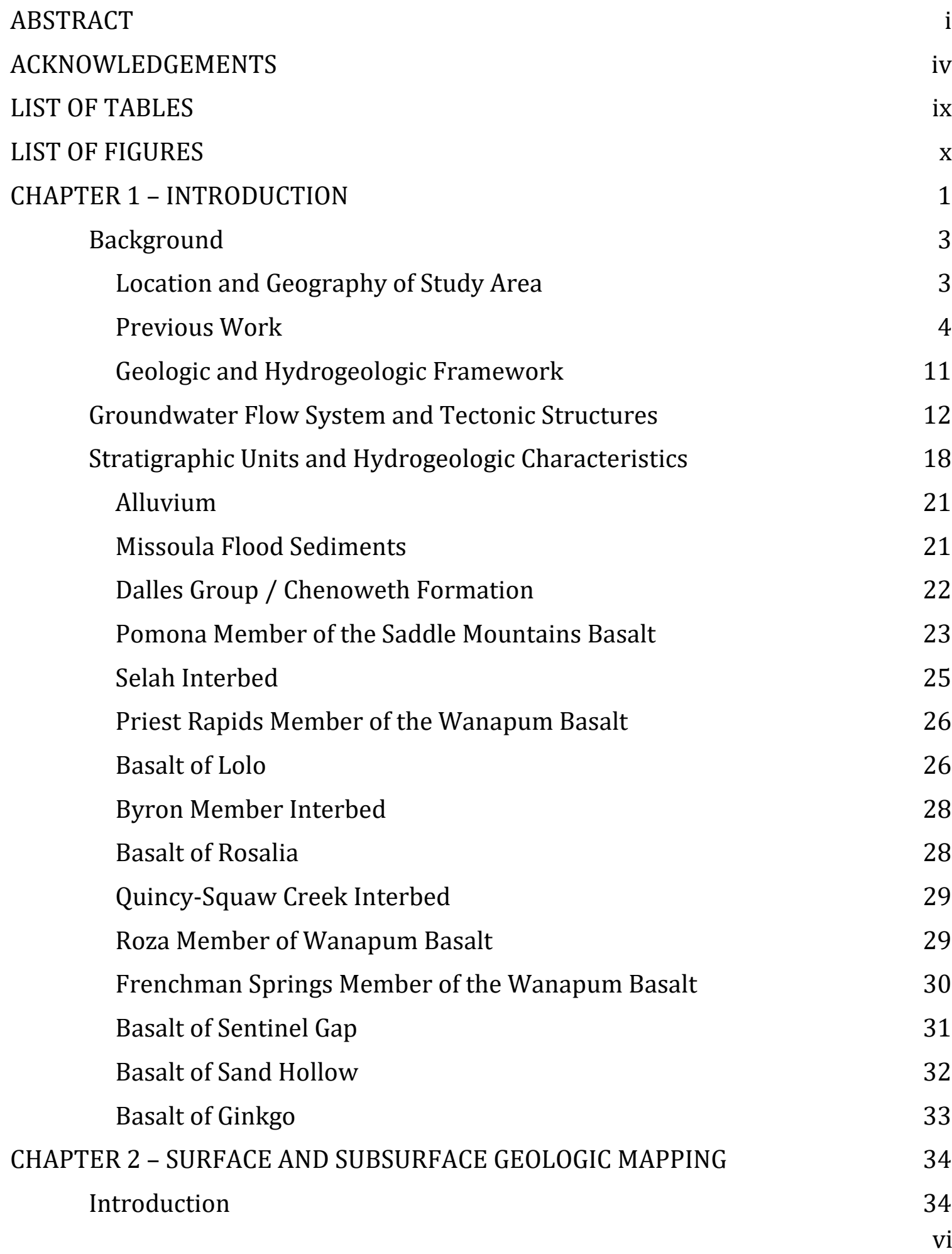


Methods $\quad 35$

Subsurface Geology Results 38

XRF Analysis of Well-Cuttings 38

Well Determinations from XRF and Well Log Analysis 47

Surface Geologic Mapping Results 51

Hand Sample XRF Results Along Streams 51

Mosier Creek 53

Dry Creek 54

Rowena Creek 56

Geologic Maps: Mosier, Dry, and Rowena Creeks 57

$\begin{array}{ll}\text { Discussion } & 60\end{array}$

$\begin{array}{ll}\text { Subsurface Geology } & 60\end{array}$

Surface Geology $\quad 62$

CHAPTER 3 - PHYSICAL AND CHEMICAL HYDROGEOLOGY 64

$\begin{array}{ll}\text { Introduction } & 64\end{array}$

$\begin{array}{ll}\text { Background } & 64\end{array}$

$\begin{array}{ll}\text { Stable Isotopes } & 65\end{array}$

$\begin{array}{ll}\text { Geochemical Signatures } & 67\end{array}$

$\begin{array}{ll}\text { Methods } & 68\end{array}$

$\begin{array}{ll}\text { Groundwater-Level Data } & 68\end{array}$

$\begin{array}{ll}\text { Stream Discharge Data } & 70\end{array}$

Spring and Surface-Water Sampling 72

Well Sampling $\quad 74$

Cation, Anion, and Silica Analysis $\quad 75$

$\begin{array}{ll}\text { Isotope Analysis } & 75\end{array}$

$\begin{array}{ll}\text { Results } & 76\end{array}$

$\begin{array}{ll}\text { Physical Hydrogeology Results } & 76\end{array}$ 
$\begin{array}{ll}\text { Groundwater-Level Data } & 76\end{array}$

$\begin{array}{ll}\text { Stream Discharge Data } & 79\end{array}$

$\begin{array}{ll}\text { Uncertainty } & 80\end{array}$

Chemical Hydrogeology $\quad 84$

Major Element Chemistry $\quad 84$

$\begin{array}{ll}\text { Stable Isotopes } & 104\end{array}$

$\begin{array}{ll}\text { Discussion } & 107\end{array}$

$\begin{array}{ll}\text { Physical Hydrogeology } & 107\end{array}$

$\begin{array}{ll}\text { Chemical Hydrogeology } & 111\end{array}$

Cluster Analysis and Principal Components Analysis 118

$\begin{array}{ll}\text { Stable Isotopes } & 120\end{array}$

CHAPTER 4 - SUMMARY AND CONCLUSIONS 129

REFERENCES CITED 133

$\begin{array}{ll}\text { APPENDIX A } & 137\end{array}$

$\begin{array}{ll}\text { XRF Analysis Data of Well-Cuttings } & 137\end{array}$

XRF Analysis Data of Hand Samples 141

$\begin{array}{ll}\text { APPENDIX B } & 142\end{array}$

$\begin{array}{ll}\text { Well Logs } & 142\end{array}$ 


\section{List of Tables}

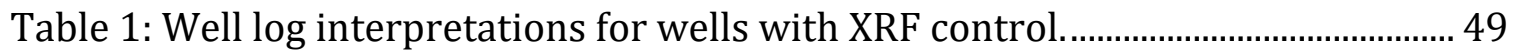

Table 2: Well log interpretations for wells with no XRF control, but were selected for

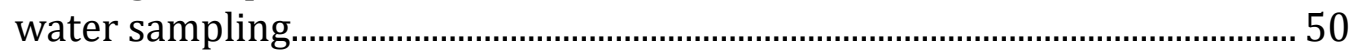

Table 3: Well construction summary for wells with available hydrochemistry and/or

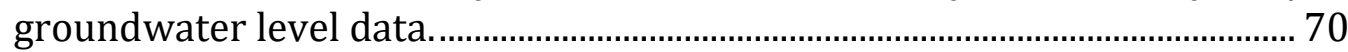

Table 4: Location information and summary of field parameters for well, stream, and spring samples.

Table 5: Major ion concentrations (mg/L) in water samples from wells in Mosier, OR, 2012.

Table 6: Minor and trace element total ion concentrations (ug/L; except $\mathrm{HPO}_{4}$ and $\mathrm{NO}_{3}$, which are in $\mathrm{mg} / \mathrm{L}$ ) in water samples from wells in Mosier, OR, 2012. Blank cells indicate that the concentration is below detection limit. Also shown are speciated charge balance errors (C.B.E. \%) for each sample calculated with PhreeqC.

Table 7: Major ion concentrations (mg/L) in spring and stream samples in Mosier, OR, 2012. Blank cells indicate that the concentration is below detection limit.

Table 8: Minor and trace element ion concentrations (ug/L; except $\mathrm{HPO}_{4}$ and $\mathrm{NO}_{3}$, which are in mg/L) in spring and stream samples in Mosier, OR, 2012. Blank cells indicate that the concentration is below detection limit. Also shown are speciated charge balance errors (C.B.E. \%) for each sample calculated with PhreeqC.

Table 9: Stable Isotope concentrations of $\delta^{18} 0$ and $\delta D$ in standard \%o notation.....104

Table 10: Inferred recharge elevation from James' (1999) linear regression relationship between $\delta^{18} 0$ values from precipitation in the central Cascades. 


\section{List of Figures}

Figure 1: Mosier, Oregon is located near the western extent of the Yakima Fold Belt Subprovince of the Columbia River Flood Basalt Province (modified from Reidel et al., 2003).

Figure 2: The project Area concerns the lower reaches of Mosier Creek, and to a lesser extent, Dry Creek and Rowena Creek. The Oregon Water Resources Department Administrative Area (orchard tract area from Lite and Gondin, 1988) is the primary location of declining groundwater levels. The black outline is the hydrologic unit boundary which encompasses the drainages of Rock Cr., West Fork Mosier Cr., Mosier Cr, and Rowena Cr.

Figure 3: Water level data from the Mosier area, 1944-2008 (Burns et al., 2012). Burns et al. (2012) monitored thirty-seven wells over a two-year period, from 2005 to 2007, and compiled the data with historic water level data to document over $40 \mathrm{~m}$ of water level decline at a rate of $1.2 \mathrm{~m}$ per year. All Group 1 wells are located within the OWRD Administrative Area.

Figure 4: Hydrographs for Mosier area wells representing Pomona, Priest Rapids, and Frenchman Springs aquifers and the change in slope of the decline trend in 2004 (Lite, 2013). Tp: Pomona Member, Tpr: Priest Rapids Member (undivided), Tprl: Priest Rapids Basalt of Lolo, Tf: Frenchmen Springs Member.

Figure 5: Idealized interaction of aquifer units and Mosier Creek (Lite, 2013). The groundwater level in area wells is likely controlled by the discharge elevation of the Pomona aquifer through interconnected (commingling) wells providing a pathway for deeper aquifer water to exit the groundwater system into Mosier Creek. Tdc: Dalles Group Chenoweth Formation, Tp: Pomona Member, Tes: Selah interbed, Tprl: Priest Rapids Basalt of Lolo, Tprr: Priest Rapids Basalt of Rosalia, Tf: Frenchmen Springs Member.

Figure 6: Generalized flow characteristics for sheet flows of Columbia River Basalt (Tolan et al., 2009).

Figure 7: Geologic map of the Mosier study area displaying the most prominent tectonic structures. Most important to this study is the Rocky Prairie Thrust Fault, forming a low flow boundary between the Columbia Hills anticline and Mosier syncline. Although not labeled, the Rocky Prairie anticline is just north of the thrust fault. The shaded portion is the OWRD Administrative area and the circles are the Mosier area wells (Burns et al., 2012, compiled from Newcomb (1969), Swanson et al. (1981), Lite and Grondin (1988), Kienle (1995), and Jervey (1996)). Units: Qal: alluvium 
Qls: Landslide, Qgf: Glaciofluvial, Tdc: Dalles Group Chenoweth Formation, Tp: Pomona Member, Tpr: Priest Rapids Member (undifferentiated), Tf: Frenchman Springs Member (undifferentiated), Tg: Grand Ronde Formation.

Figure 8: Cross section of the Rocky Prairie thrust fault, Rocky Prairie anticline, and Mosier syncline (McClaughry et al., 2013), looking toward the east. Units: Tsp: Pomona Member, Twpl: Priest Rapids Basalt of Lolo, Twpr: Priest Rapids Basalt of Rosalia, Twfs: Frenchman Springs Basalt of Sentinel Gap, Twfh: Frenchman Springs Basalt of Sand Hollow.

Figure 9: Slickensides within the Pomona Member, which served to further constrain the location and orientation of the Rocky Prairie thrust fault.... 16

Figure 10: Steeply dipping hackly entablature within the hanging wall of the Rocky Prairie thrust fault along Huskey Rd. 17

Figure 11: Stratigraphy of the Columbia River Basalt Group (CRBG) and associated sedimentary interbeds near Mosier, OR (Modified from Lite and Grondin, 1988; Reidel et al., 2002; Tolan et al., 2009; and Lite, 2013). Magnetic Polarity: Normal (N), Reverse (R), Excursional (E), Transitional (T). Labeling scheme from Lite (2013) is included for reference with figures from his study, which were provided earlier in this write-up.

Figure 12: Columbia River Basalt Group stratigraphy exposed in Rowena Dell, looking West from the eastern side of the Dell (modified from Lite and LaMarche, 2014)

Figure 13: Road cut exposing volcanic debris flow conglomerate of the Dalles Formation in upper elevations of the Mosier Creek watershed.

Figure 14: Fresh surface of a Pomona hand sample displaying a fine-grained groundmass..

Figure 15: Fine-grained groundmass with sporadic plagioclase microphenocrysts ( $<5 \mathrm{~mm}$ ). Photo is from McClaughry et al., 2012.

Figure 16: Pomona Basalt outcrop displaying massive columns transitioning upward to commonly seen thin, hackly entablature. 24

Figure 17: Close-up photo of Lolo in sample Gage 2 collected from within Mosier Creek (McClaughry et al., 2012).

Figure 18: Lolo hand sample showing a medium-grained groundmass and platy appearance.

Figure 19: Massive columns of the Lolo flow, smoothed and rounded by Mosier Creek. 
Figure 20: Pillow lava at the base of Lolo flow exposed in a road cut near Mosier, OR.

Figure 21: Basalt of Rosalia in hand sample showing fine to medium-grained groundmass and vesicles, some with secondary mineralization (left)....... 29

Figure 22: Medium-grained aphyric groundmass of the Basalt of Rosalia (McClaughry et al., 2012).

Figure 23: Roza Member in hand sample displaying prominent plagioclase phenocrysts making it an important marker bed, where present. It is only present in Rowena Dell for this study area. 30

Figure 24: Hand sample of a vesicular flow top within the Sentinel Gap flow of the Frenchmen Springs Member.

Figure 25: Representative hand sample of Sentinel Gap flow interior with fine to medium-grained groundmass and rarely plagioclase phyric (McClaughry et al., 2012).

Figure 26: Representative hand sample of Sand Hollow flow displaying a finegrained groundmass, which is sparsely plagioclase phyric (McClaughry et al., 2012).

Figure 27: CRBG flow identification in the Mosier area via chemical analysis of rock cuttings utilizing a $\mathrm{TiO}_{2}$ vs. Cr variation diagram (Lite, 2013). Units: Tp: Pomona, Tprl: Lolo, Tprr: Rosalia, Tfsg: Sentinel Gap, Tfsh: Sand Hollow. 36

Figure 28: An example well log where driller's notes, describing water-bearing units and sedimentary interbeds, can help identify and estimate the thickness of subsurface CRBG flows. Well construction details were also utilized to determine which aquifers could potentially contribute water to the well. 40

Figure 29: XRF analysis results for all well cuttings. Tsp: Pomona, Twpl: Lolo, Twpr: Rosalia, Twfsg: Sentinel Gap, Twfsh: Sand Hollow. 41

Figure 30: Mosier area wells for which units were identified via XRF analyses of cuttings.

Figure 31: $\mathrm{TiO}_{2}$ vs $\mathrm{Cr}$ variation diagram for each well, displaying the XRF analysis results for well cuttings. Tsp $=$ Pomona, Twpl $=$ Lolo, Twpr $=$ Rosalia, Twfsg $=$ Sentinal Gap, Twfsh $=$ Sand Hollow. 45

Figure 32: $\mathrm{TiO}_{2}$ vs $\mathrm{Cr}$ variation diagram for each well, displaying the XRF analysis results for well cuttings. Tsp $=$ Pomona, Twpl $=$ Lolo, Twpr $=$ Rosalia, Twfsg $=$ Sentinal Gap, Twfsh $=$ Sand Hollow. 46 
Figure 33: $\mathrm{TiO}_{2}$ vs $\mathrm{Cr}$ variation diagram for each well, displaying the XRF analysis results for well cuttings. Tsp $=$ Pomona, Twpl $=$ Lolo, Twpr $=$ Rosalia, Twfsg $=$ Sentinal Gap, Twfsh $=$ Sand Hollow.

Figure 34: Location map of wells with well log interpretation, well-cutting XRF, and/or water sampling. State Well number is included as the label and the producing aquifer of each well is denoted by the symbol and legend. Tsp: Pomona, Twpl: Lolo, Twpr: Rosalia, Twfsg: Sentinel Gap, Twfsh: Sand Hollow. Wells interconnecting multiple aquifers have more than one aquifer listed in the legend (ex. Twpl/pr: Lolo and Rosalia).

Figure 35: $\mathrm{TiO}_{2}$ vs $\mathrm{Cr}$ variation diagram displaying the hand sample XRF analysis results from the Mosier area along Mosier Creek and Dry Creek. Tsp: Pomona, Twpl: Lolo, Twpr: Rosalia.

Figure 36: Location map of all hand samples collected in the Mosier area, both with and without XRF data, along Mosier, Dry, and Rowena Creeks. 52

Figure 37: Outcrop where mol 1 was collected, representing the Lolo flow top with abundant vesicles exposed in Mosier Creek.

Figure 38: Pomona outcrop along Mosier Creek, displaying the commonly seen thin, hackly entablature of middle and upper portions of this flow. 54

Figure 39: Small spring issuing from the Lolo and Rosalia contact along Dry Creek.55

Figure 40: Thin, platy, and highly fractured outcrop of the Lolo flow in Dry Creek where sample har 4 was collected

Figure 41: Outcrop of Rosalia within Dry Creek displaying a thin, platy, and fractured appearance overlying massive columns (sample har 9). 56

Figure 42: Spring within Rowena Creek during late September, 2011, issuing from the upper Frenchman Springs flow.

Figure 43: Detailed geologic mapping results for Columbia River Basalt flow outcrops within the upper portions of Mosier Creek and Dry Creek (modified from a compilation of Newcomb (1969), Lite and Grondin (1988), McClaughry et al. (2012), and Lite (2013). The lower reaches of Mosier Creek are shown in the next figure. Ha: alluvium (Holocene), Qmfs/Qmfsg: Missoula flood deposits, Qa: alluvium (Quaternary), Qls: Landslide deposit, Tdc: Dalles Gr. Chenoweth Form., Tsp: Pomona, Twpl: Lolo, Twpr: Rosalia, Twfsg: Sentinel Gap, Twfsh: Sand Hollow.

Figure 44: Detailed geologic mapping results and spring location displaying lower Mosier Creek and the eastern portion of the study area with Rowena Creek (modified from a compilation of Newcomb (1969), Lite and Grondin (1988), and Burns et al. (2012). Refer to Figure 11 for label descriptions. 
Ha: alluvium (Holocene), Qmfs/Qmfsg: Missoula flood deposits, Qa: alluvium (Quaternary), Qls: Landslide deposit, Tdc: Dalles Gr. Chenoweth Form., Tsp: Pomona, Twpl: Lolo, Twpr: Rosalia, Twfsg: Sentinel Gap, Twfsh: Sand Hollow. 59

Figure 45: Cation ratio $(\mathrm{Na}+\mathrm{K}) /(\mathrm{Na}+\mathrm{K}+\mathrm{Ca}+\mathrm{Mg})$ versus Carbon-14 activity (percent modern) from CRBG groundwater samples from central Washington (Vlassopoulos et al., 2009). SW: wells producing from Saddle Mountains and Wanapum Basalts, W: Wells from Wanapum Basalts, WG: wells producing from Wanapum and Grand Ronde Basalt, and G: wells producing only from Grande Ronde Basalt. 68

Figure 46: Location map for all water sampling: wells, streams, springs. The location of the upper and lower stream gages is also shown. Refer to Figure 11 for a complete unit description. Tsp: Pomona, Twpl: Lolo, Twpr: Rosalia, Twfsg: Sentinel Gap, Twfsh: Sand Hollow. 72

Figure 47: Hydrographs for seven wells within the OWRD Administrative Area, displaying the substantial groundwater-level decline over the period of record, as well as an apparent common equilibrium elevation for area wells occurring in 2004 (Lite, 2013). Domestic wells are displayed with dashed lines and irrigation wells have solid lines. The interflow zone(s) of each well are displayed in the legend. Refer to Table 3 for well construction details. Tsp: Pomona, Twpl: Lolo, Twpr: Rosalia, Twfsg: Sentinel Gap, Twfsh: Sand Hollow.

Figure 48: Groundwater level decline trends for WASC 2759 split between 1974 2003 and $2004-2015$

Figure 49: Steam discharge data and gains/losses across the Lolo/Pomona aquifers in Mosier Creek from April 2012 through December 2012. 82

Figure 50: Steam discharge data and gains/losses across the Lolo/Pomona aquifers in Mosier Creek from March 2013 through December 2013.

Figure 51: Steam discharge data and gains/losses across the Lolo/Pomona aquifers in Mosier Creek from March 2014 through December 2014. 83

Figure 52: Steam discharge data and gains/losses across the Lolo/Pomona aquifers in Mosier Creek from March 2015 through December 2015. 83

Figure 53: Piper diagram for all wells and springs sampled during sampling campaign 1 (May-August 2012). All samples plot as mixed cation bicarbonate waters. See Figure 46 for sample locations. 
Figure 54: Piper diagram for all wells, springs, and streams sampled in sampling campaign 2 (October 2012). All samples plot as mixed cation - bicarbonate waters. See Figure 46 for sample locations.

Figure 55: Ionic concentrations for all wells and springs sampled during Campaign 1 (May - August 2012). See Figure 46 for sample locations................................. 95

Figure 56: Ionic concentrations for all samples collected during sampling campaign 2 (October 2012). See Figure 46 for sample locations. 96

Figure 57: Ionic concentrations for streams sampled in October 2012. See Figure 46

for sample locations. 97

Figure 58: Cation Ratio vs F- for Sampling Campaigns 1 and 2. ................................... 98

Figure 59: Cation Ratio vs $\mathrm{Na}^{+}$plots divided by sampling campaign............................. 99

Figure 60: Cation Ratio vs $\mathrm{K}^{+}$for each sampling campaign............................................100

Figure 61: Cation Ratio vs $\mathrm{Mg}^{2+}$ for each sampling campaign.......................................101

Figure 62: Cation Ratio vs $\mathrm{Cl}$ - for each sampling campaign............................................102

Figure 63: Specific Conductance vs pH plot for each sampling campaign...................103

Figure 64: $\delta^{2} \mathrm{H}$ vs $\delta^{18} 0$ plot for samples from this study along with other study results from the Oregon Cascades for comparison. Sample locations for this study were provided in Figure 46. The Global Meteoric Water Line and Local Meteoric Water Lines are displayed for each study (Craig, 1961, Ingebritsen et al., 1988, James, 1999, and Nathenson (2004).......................106

Figure 65: 2013 Water level trend for WASC 2760 (Pomona aquifer) plotted with the percent difference between upper streamflow gage and lower stream gage. The figure indicates the stream transitions from slightly gaining water from the groundwater system, to losing water to the groundwater system, which is coincident with drawdown in the well. These findings are consistent with those of Lite and LaMarche (2014).

Figure 66: 2014 Water level trend for WASC 2760 (Pomona aquifer) plotted with the percent difference between upper streamflow gage and lower stream gage. The figure indicates the stream transitions from slightly gaining water from the groundwater system, to losing water to the groundwater system, which is coincident with drawdown in the well. These findings are consistent with those of Lite and LaMarche (2014).

Figure 67: Cation Ratio vs F- for sampling campaign 2 with circles around the upper and lower watershed well groupings. The lower watershed wells consist of the suspected highly commingled well grouping, while the higher cation 
ratio of WASC 2767 and 50250 is thought to be the result of the wells being located up-gradient from the commingling.

Figure 68: Hydrographs for seven wells within the OWRD Administrative Area, displaying the groundwater levels from 2004 through 2016. WASC 50012 has a lower head than Lolo/Rosalia commingled wells from 2004 through late 2012. Domestic wells are displayed with dashed lines and irrigation wells have solid lines. The interflow zone(s) of each well are displayed in the legend. Refer to Table 3 for well construction details. Tsp: Pomona, Twpl: Lolo, Twpr: Rosalia, Twfsg: Sentinel Gap, Twfsh: Sand Hollow. ......117

Figure 69: Biplot of principal components 1 and 2 with symbols representing each well's representative aquifer(s). The red, blue, and green groupings are the groupings from cluster analyses.

Figure 70: $\delta^{18} \mathrm{O}$ as a function of ${ }^{14} \mathrm{C}$ apparent age from Carey (2011). Lower aquifer waters are red and upper aquifers are blue, showing recharge from the Pleistocene in lower aquifers. Referencing my $\delta^{18} 0$ values with this data indicates all the Mosier area wells likely contain modern recharge on the order of tens to hundreds of years at most, as opposed to thousands of years.

Figure 71: Inferred recharge elevation for samples from this study. The relationship between sample elevation of recharge as determined by James (1999) from snow core samples in the Central Cascades. The approximate recharge elevation is estimated by tracing a line to the linear regression, and then another line down to the elevation, inferred to be the elevation where precipitation is comparable. 


\section{Chapter 1- Introduction}

Columbia River Basalt Group (CRBG) aquifers serve as the principle water source for much of the Columbia Basin, including the area around Mosier, Oregon near the east end of the Columbia River Gorge. The CRBG aquifers in the Mosier area have experienced groundwater elevation declines of between 45 and 60 meters since the 1970s (Burns et al., 2012), leading to concerns over the sustainability of the resource. Previous studies of groundwater declines in CRBG aquifers here and elsewhere in the Columbia River basin have focused on non-sustainable pumping and or drainage of specific aquifers by cross-connecting or "comingling" water wells (Lite and Grondin, 1988; Porcello et al., 2009; Burns et al., 2012). Comingling occurs in wells, often those with long open / uncased sections, that provide a flow path from an aquifer with higher hydraulic head to an aquifer with lower hydraulic head, resulting in the composite depressurization of aquifers.

One potentially important process that may significantly impact groundwater levels but which has received relatively little attention is the interaction between CRBG aquifers and surface water drainages. Surface streams can serve as groundwater flow system boundaries where they intersect surface exposures of aquifers due to streambed erosion (Lite, 2013). A better understanding of surface water - groundwater interactions and the control exerted on these interactions by stratigraphy and local structures is needed for better flow system modeling and sound resource management. 
The Mosier, Oregon, watershed provides an excellent opportunity to research the CRBG aquifer interaction with surface water drainages because a reasonable understanding of many other hydrogeologic parameters exists, such as the subsurface geologic framework and hydraulic head distribution. The watershed lies within one Yakima fold, the Mosier Syncline; thus, it may provide the best opportunity to characterize CRBG flow systems as a whole (Lite, 2013). The study of Mosier area hydrogeology is also important in that its findings would likely be applicable to other regions similarly situated within the Yakima Fold Belt (Figure 1).

The goal of my research is to further investigate interactions between the groundwater system and Mosier Creek and to establish the extent to which stratigraphic position and local geologic structures control these interactions. In doing so, this research attempts to test the hypothesis that the top of the Pomona interflow zone exposed in Mosier Creek represents the lowest point in which groundwater exits the CRBG aquifers in the Mosier area, thus controlling the local head elevations (Lite, 2013).

The specific objectives of this study are to: 1) identify geologic contacts along Mosier Creek, and to a lesser extent Dry Creek and Rowena Creek; 2) compile stream discharge data across the geologic contacts to characterize CRB aquifer and stream interactions; 3) determine if hydrochemical evidence supports the hypothesized groundwater - surface water interaction through analysis of water samples from area wells, streams, and springs. The water sampling component of 
this study also involves an investigation into the delineation of discrete CRB aquifers from hydrochemical analysis. Further description and background information of the hydrochemical aspect of this study is provided in Chapter 3.

\section{Background}

\section{Location and Geography of Study Area}

Mosier, Oregon is located approximately seven miles east of Hood River, Oregon in the northwestern corner of Wasco County along the Columbia River. The Mosier Creek watershed is $207 \mathrm{~km}^{2}$ in the transitional zone between the High Cascades to the west and the Columbia Plateau to the east (Figure 1).

This research pertains to the northern $90 \mathrm{~km}^{2}$ of the watershed. Due to orographic precipitation effects, yearly average rainfall increases from east to west ranging from 50 to $80 \mathrm{~cm}$. Three small tributaries feed the Columbia River in this region: Rock Creek, Mosier Creek, and Rowena Creek. Mosier Creek is the only perennial stream in the study area. Both West Fork Mosier Creek and Dry Creek are tributaries feeding into Mosier Creek. The primary focus of this study is the lower stretch of Mosier Creek from just above the confluence of West Fork Mosier Creek to just below the confluence of Dry Creek (Figure 2). Elevations range from $30 \mathrm{~m}$ (100 feet) near the Columbia River to over 700 m (2,300 feet) at Wasco Butte. Surface drainages are incised into a general northwest-dipping slope of 3 to 11 degrees, which reflects the dip of the Columbia River Basalts (Lite and Grondin, 1988) down 
the flank of the NE-trending Columbia Hills Anticline. Land use is varied between agriculture, forestland, and rural residences. The leading industry is agriculture with 1,440 irrigated acres consisting of predominantly cherry orchards (Clark and Loop, 2002).

\section{Previous Work}

Previous research has shown significant declines of up to 40 to $60 \mathrm{~m}$ in groundwater levels since the 1960s and 1970s in the Mosier area (Lite and Grondin, 1988; Burns et al., 2012; Lite, 2013). Groundwater is utilized extensively for the commercial irrigation of cherry orchards and as drinking water for the entire watershed. Lite and Grondin (1988) attributed groundwater declines (up to $40 \mathrm{~m}$ at the time) to over-pumping and commingling wells. As a result of that study, the Oregon Department of Water Resources (OWRD) withdrew further commercial groundwater appropriations from the two most heavily utilized aquifers in the orchard tract area (Figure 2). 


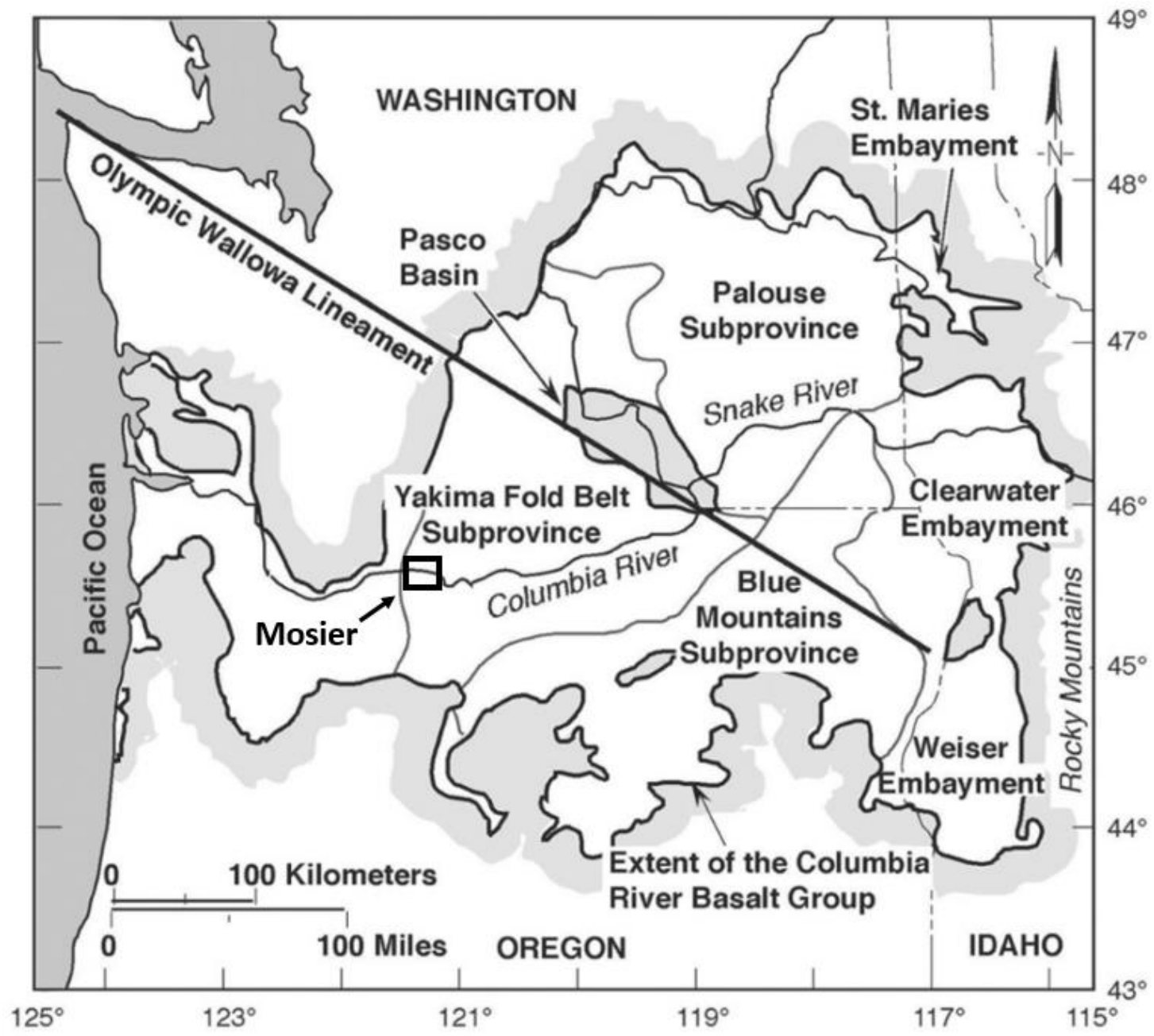

Figure 1: Mosier, Oregon is located near the western extent of the Yakima Fold Belt Subprovince of the Columbia River Flood Basalt Province (modified from Reidel et al., 2003). 


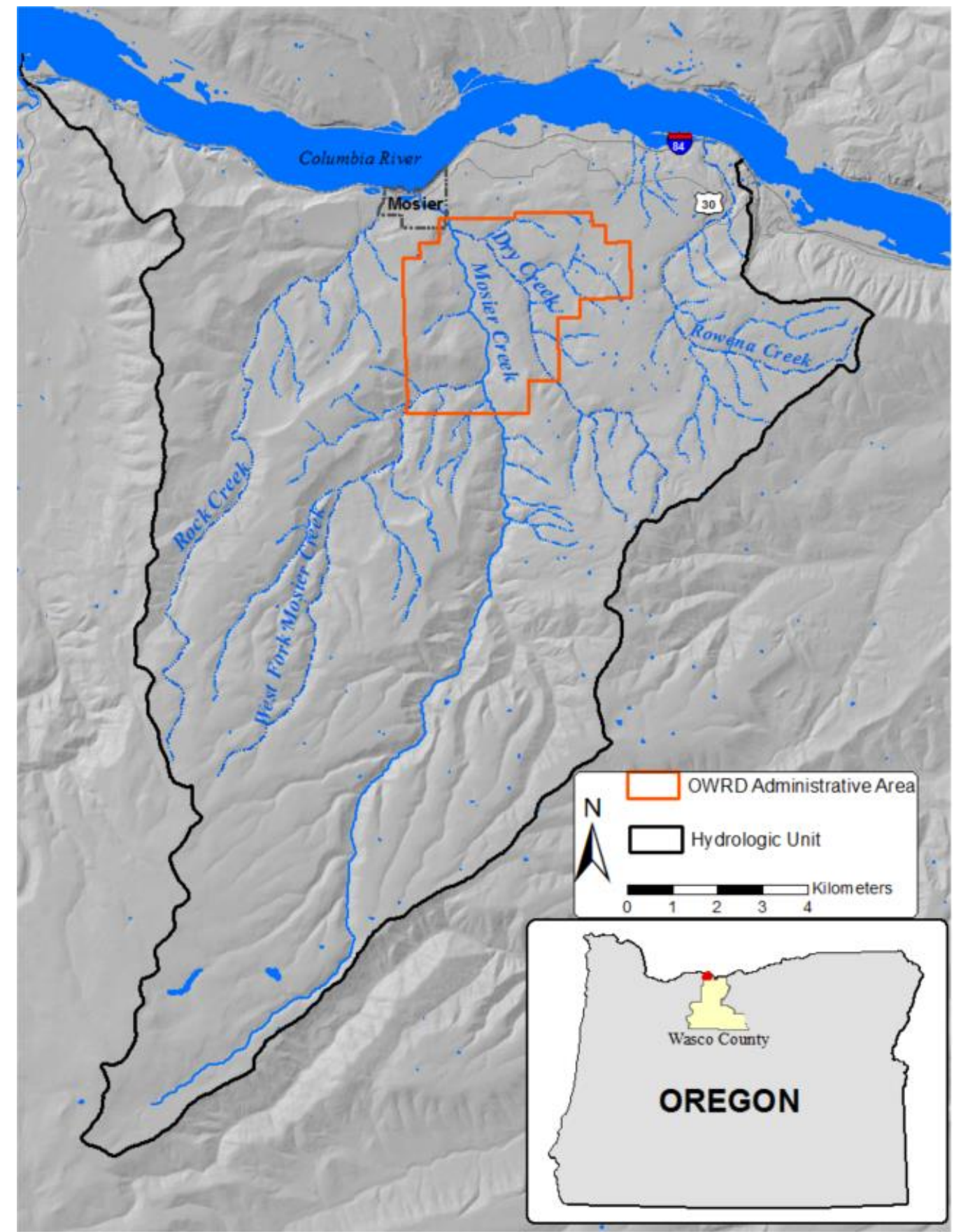

Figure 2: The project Area concerns the lower reaches of Mosier Creek, and to a lesser extent, Dry Creek and Rowena Creek. The Oregon Water Resources Department Administrative Area (orchard tract area from Lite and Gondin, 1988) is the primary location of declining groundwater levels. The black outline is the hydrologic unit boundary which encompasses the drainages of Rock Cr., West Fork Mosier Cr., Mosier Cr, and Rowena Cr. 
In 2005, the U.S. Geological Survey (USGS) entered into a cooperative agreement with the Wasco County Soil and Water Conservation District and the Mosier Watershed Council to conduct research geared towards developing a sustainable yield of groundwater resources for the Mosier area. As a result of this agreement, Burns et al. (2012) monitored thirty-seven wells over a two-year period, from 2005 to 2007, and consolidated this with historic water level data (Figure 3). Burns et al. (2012) found that the probable dominant cause of decline is commingling. Burns et al. (2012) estimated that as many as 150 wells in the Mosier area could be commingling and found that one well was contributing between 15 and $30 \mathrm{~m}^{3} / \mathrm{hr}$ (70 and 135 gallons per minute or gpm) to the upper aquifer(s), which amounts to 11-22 percent of total annual pumping for the area. Lite and Grondin (1988) had documented the effects of aquifers interconnected by well construction and estimated that 187,000 m³/yr (152 acre-feet per year or over 27 percent of annual recharge for upper aquifer) was being recharged from stratigraphically lower aquifers to the upper aquifer and subsequently being discharged to Mosier Creek. 


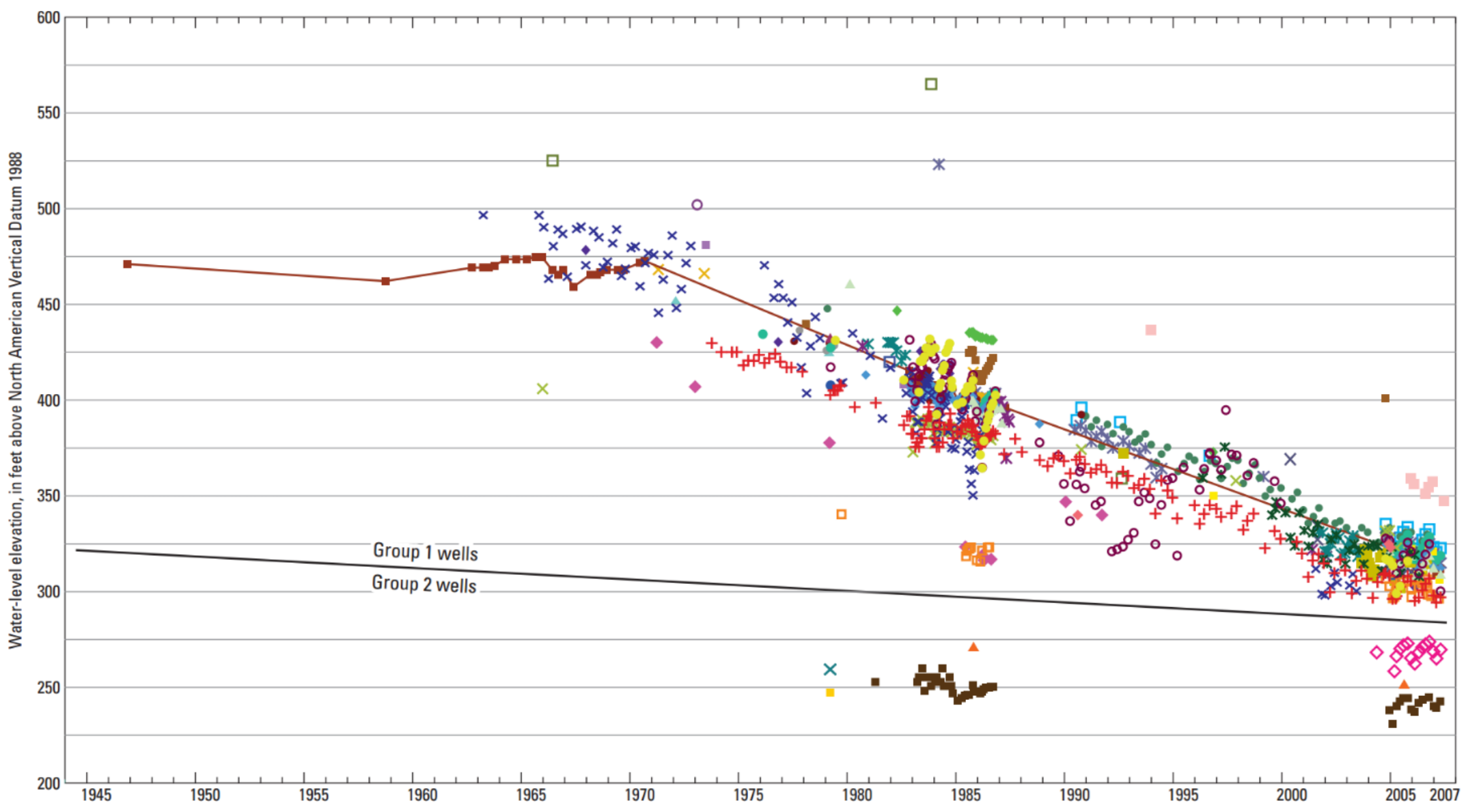

Figure 3: Water level data from the Mosier area, 1944-2008 (Burns et al., 2012). Burns et al. (2012) monitored thirty-seven wells over a twoyear period, from 2005 to 2007 , and compiled the data with historic water level data to document over $40 \mathrm{~m}$ of water level decline at a rate of $1.2 \mathrm{~m}$ per year. All Group 1 wells are located within the OWRD Administrative Area. 
Lite (2013), through a study linking local hydrographs and detailed area stratigraphy, revealed a change in slope of the decline trend in deeper aquifers (Frenchman Springs and Priest Rapids) that occurred in 2004. Lite hypothesizes that this change in slope (Figure 4) represents the aquifers seeking a new equilibrium point, which is controlled by the commingling wells and the interaction of the groundwater system with Mosier Creek. He stated that the elevation where the Pomona and Lolo interflow zones are exposed in Mosier Creek likely represents the lowest point where water exits the groundwater system, thus controlling the head in area wells. This idealized interaction from the Mosier area is shown in Figure 5 (Lite, 2013).

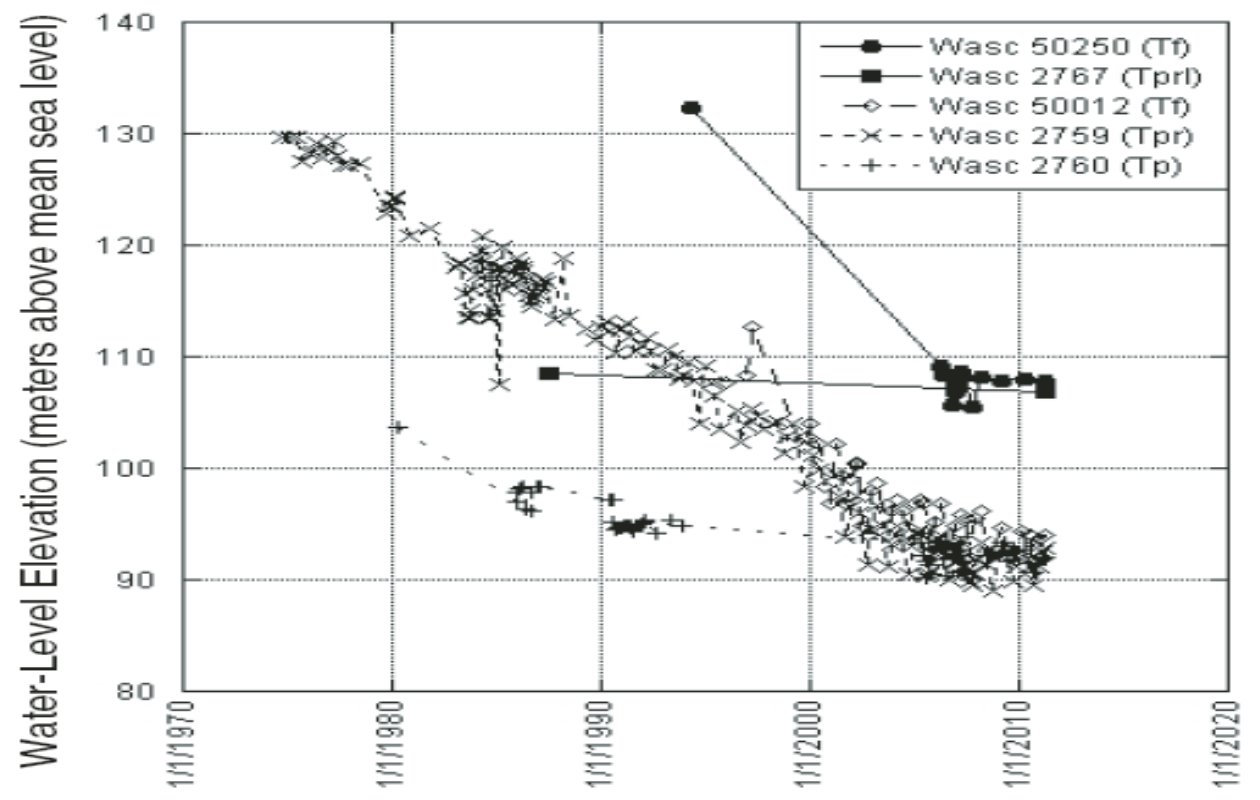

Figure 4: Hydrographs for Mosier area wells representing Pomona, Priest Rapids, and Frenchman Springs aquifers and the change in slope of the decline trend in 2004 (Lite, 2013). Tp: Pomona Member, Tpr: Priest Rapids Member (undivided), Tprl: Priest Rapids Basalt of Lolo, Tf: Frenchmen Springs Member. 


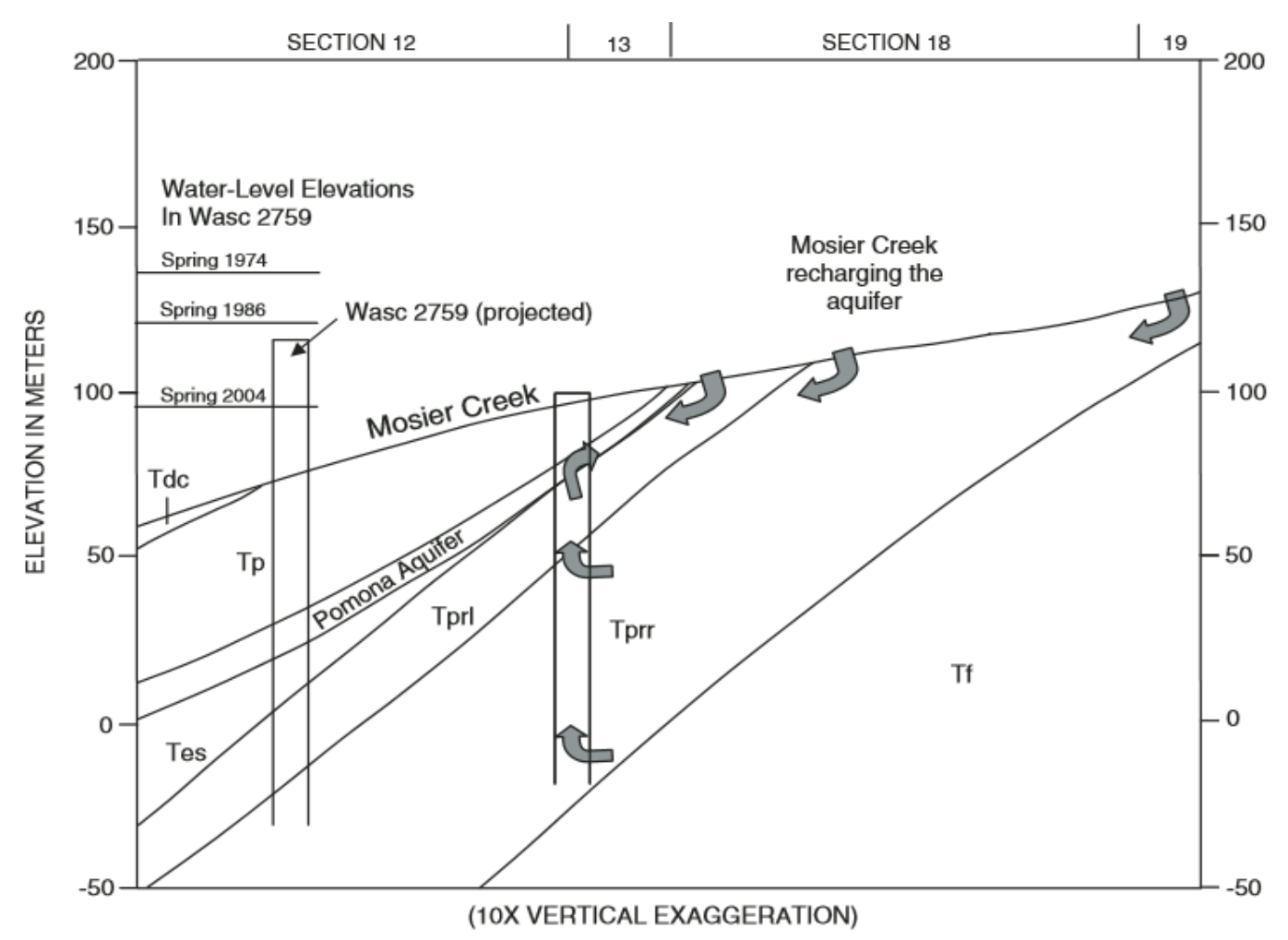

Figure 5: Idealized interaction of aquifer units and Mosier Creek (Lite, 2013). The groundwater level in area wells is likely controlled by the discharge elevation of the Pomona aquifer through interconnected (commingling) wells providing a pathway for deeper aquifer water to exit the groundwater system into Mosier Creek. Tdc: Dalles Group Chenoweth Formation, Tp: Pomona Member, Tes: Selah interbed, Tprl: Priest Rapids Basalt of Lolo, Tprr: Priest Rapids Basalt of Rosalia, Tf: Frenchmen Springs Member.

The long-term decline in groundwater has been studied in detail but understanding of surface water - groundwater interactions still remains unclear. Previous research by Newcomb (1969) found Mosier Creek to be gaining from CRBG aquifers below the confluence with West Fork Mosier Creek. A later study by Lite and Grondin (1988) found that same reach below the West Fork to be losing water to the subsurface while the lower stretches of Mosier Creek were gaining. This shift in interaction is thought to be the result of the overall groundwater decline seen in area wells, while the change in the decline trend seen in 2004 is thought to be 
correlated to the interaction between Mosier Creek and interflow zones exposed in the creek (Lite, 2013).

\section{Geologic and Hydrogeologic Framework}

The Columbia River Basalt Group (CRBG), covering 200,000 km² of eastern and central Washington, northern Oregon, and west-central Idaho, consists of over 300 individual flows of tholeiitic continental flood basalts erupted from 17 to $6 \mathrm{Ma}$ (Swanson et al., 1979; Tolan et al., 1989). The vast majority of these flows are classified as sheet flows across its coverage (Beeson et al., 1985, 1989; Beeson and Tolan, 1990, 1996; Reidel and Tolan, 1992; Reidel et al., 1994; Reidel 1998). Each sheet flow is typically composed of a flow top, dense interior, and a flow bottom (Figure 6). The water bearing units occur in interflow zones where there is a contact between the flow top of one flow and a flow bottom of an overlying flow (Newcomb, 1969; Lite and Grondin, 1988, Tolan et al., 2000).

Interflow zones can be interfingered with a sedimentary unit that can act as either a confining unit or a porous media. Although some characteristics of CRBG flows are considered remarkably homogenous throughout their extent, hydrogeologic characteristics vary on local scales due to a difference in the environment of emplacement for each successive flow and the geologic setting of an area (Lite, 2013). For the Mosier area, Lite and Grondin (1988) found transmissivity values ranging from 845 to $2,778 \mathrm{~m}^{2} /$ day for the uppermost aquifers. They found storativity values ranging from 0.00004 to 0.00009 . The relatively high value for 
transmissivity and low values for storativity indicate the effects of pumping can propagate quickly through the groundwater system.

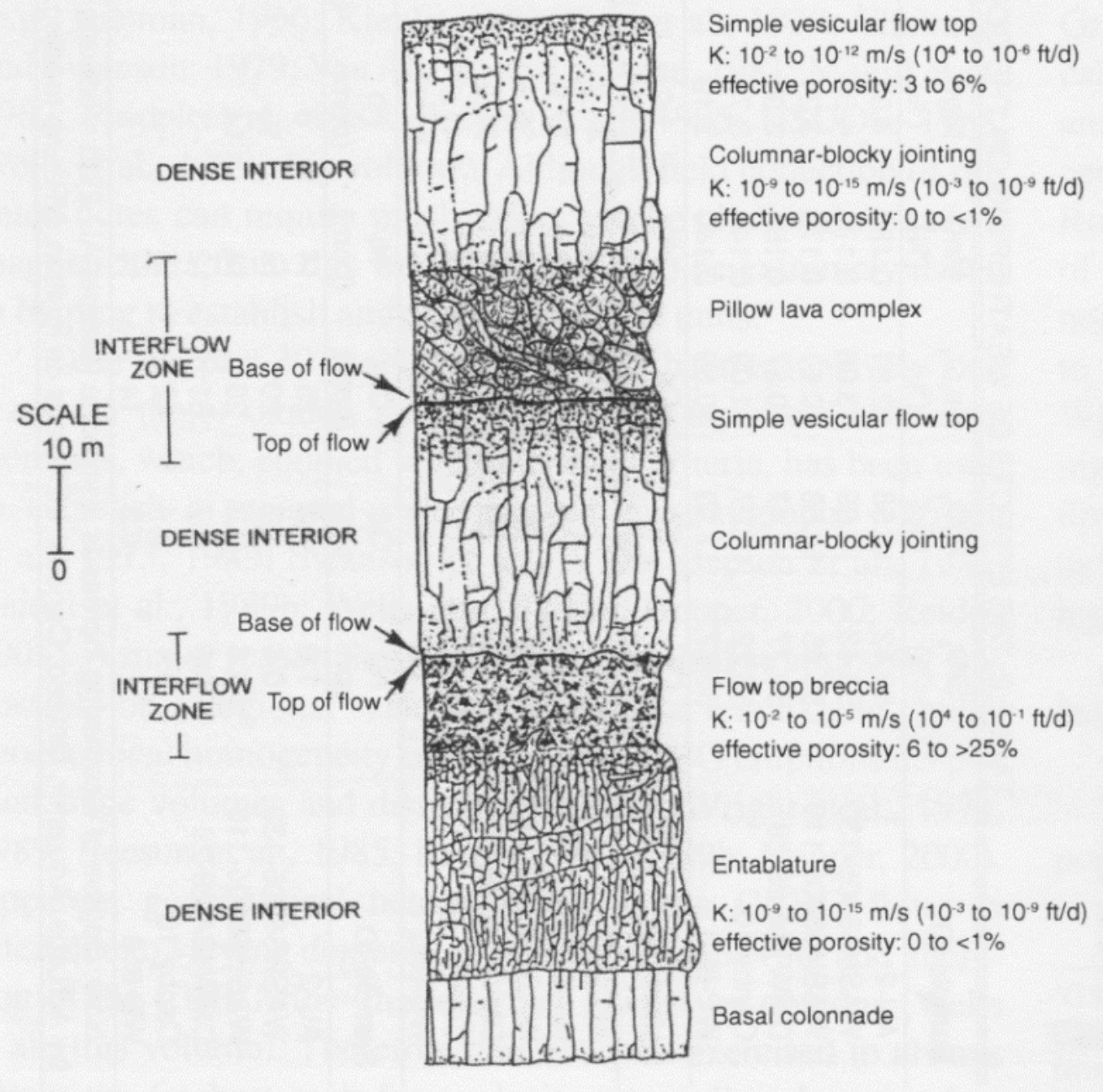

Figure 6: Generalized flow characteristics for sheet flows of Columbia River Basalt (Tolan et al., 2009).

\section{Groundwater Flow System and Tectonic Structures}

Mosier is situated within the Yakima Fold Belt, a series of narrow anticlinal ridges and broad synclinal valleys formed throughout the emplacement of the CRBG 
(Reidel, 1984). The Mosier study area and groundwater flow system occur within the northeast trending Mosier syncline. The Mosier syncline is bounded by the Columbia Hills anticline to the southeast and the Bingen anticline to the northwest (Swanson et al., 1981).

The succession from anticline to syncline provides the major control on groundwater flow as the system is thought to be recharged by precipitation along the northwest flank of the Columbia Hills anticline (Newcomb, 1969; Lite and Grondin, 1988). Groundwater flows down gradient from the Columbia Hills anticline towards the axis of the Mosier syncline until it encounters an east-northeast trending high angle reverse fault, referred to as the Rocky Prairie thrust fault (Figure 7), which acts as a flow boundary (Newcomb, 1969; Lite and Grondin, 1988). Evidence for this flow boundary was documented by Newcomb (1969) in that artesian pressures were found on the south (up-gradient) side of the fault with an overall head elevation 122 meters higher than the north side of the fault. 


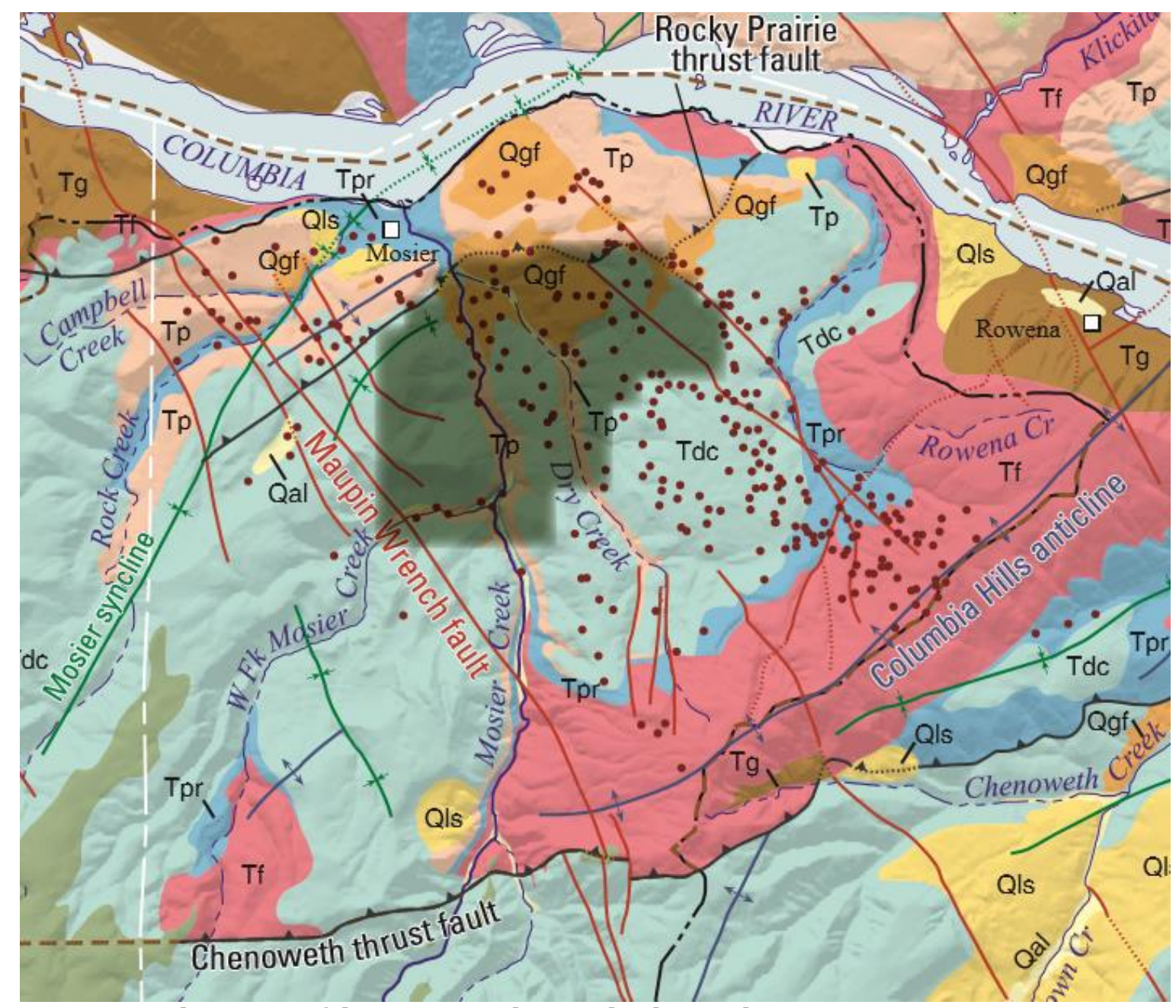

Figure 7: Geologic map of the Mosier study area displaying the most prominent tectonic structures. Most important to this study is the Rocky Prairie Thrust Fault, forming a low flow boundary between the Columbia Hills anticline and Mosier syncline. Although not labeled, the Rocky Prairie anticline is just north of the thrust fault. The shaded portion is the OWRD Administrative area and the circles are the Mosier area wells (Burns et al., 2012, compiled from Newcomb (1969), Swanson et al. (1981), Lite and Grondin (1988), Kienle (1995), and Jervey (1996)). Units: Qal: alluvium Qls: Landslide, Qgf: Glaciofluvial, Tdc: Dalles Group Chenoweth Formation, Tp: Pomona Member, Tpr: Priest Rapids Member (undifferentiated), Tf: Frenchman Springs Member (undifferentiated), Tg: Grand Ronde Formation

Additional geologic information regarding the Rocky Prairie thrust fault was discovered during this research. Although not an integral part of the new findings regarding groundwater and surface water interaction, it is included here to further 
describe the fault and constrain the fault trace. A cross section of the thrust fault is shown in (Figure 8). Bedding-parallel slickensides were identified within a faultbrecciated portion of Pomona flow along Mosier Creek, just south of the State Road bridge oriented $\mathrm{N} 30^{\circ} \mathrm{E}$ to $\mathrm{N} 50^{\circ} \mathrm{E}$, with dips ranging from $50-75^{\circ}$ to the southeast (Figure 9). This fault orientation is concordant with previous findings in this area and further constrains the fault location, as the slickensides were interpreted by McClaughry (2013) to reside in the footwall of the fault. Residing in the hanging wall block of this fault, and exposed along Husky Road, is the steeply dipping Pomona member, which is located on the southeast limb of the Rocky Prairie anticline (Newcomb, 1969; Lite and Grondin, 1988) (Figure 10). The slickensides and faultbreccia of Pomona are thought to have been exposed by relatively recent high water flows in Mosier Creek. 


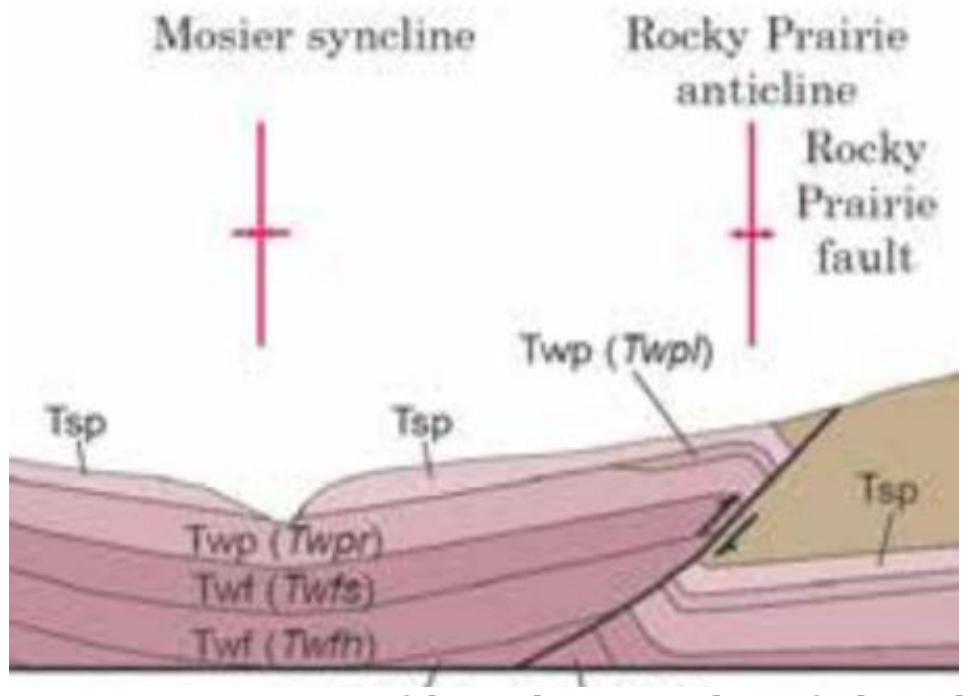

Figure 8: Cross section of the Rocky Prairie thrust fault, Rocky Prairie anticline, and Mosier syncline (McClaughry et al., 2013), looking toward the east. Units: Tsp: Pomona Member, Twpl: Priest Rapids Basalt of Lolo, Twpr: Priest Rapids Basalt of Rosalia, Twfs: Frenchman Springs Basalt of Sentinel Gap, Twfh: Frenchman Springs Basalt of Sand Hollow.

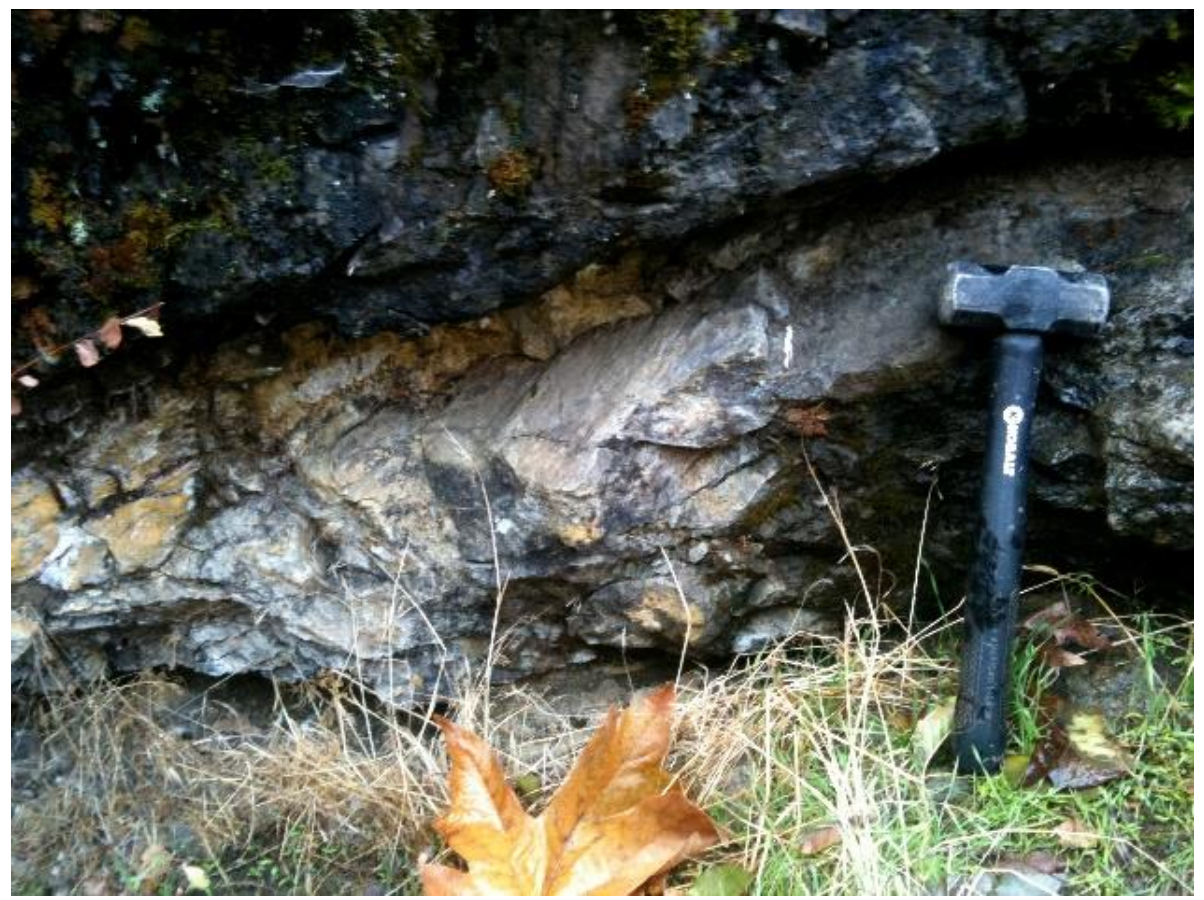

Figure 9: Slickensides within the Pomona Member, which served to further constrain the location and orientation of the Rocky Prairie thrust fault. 


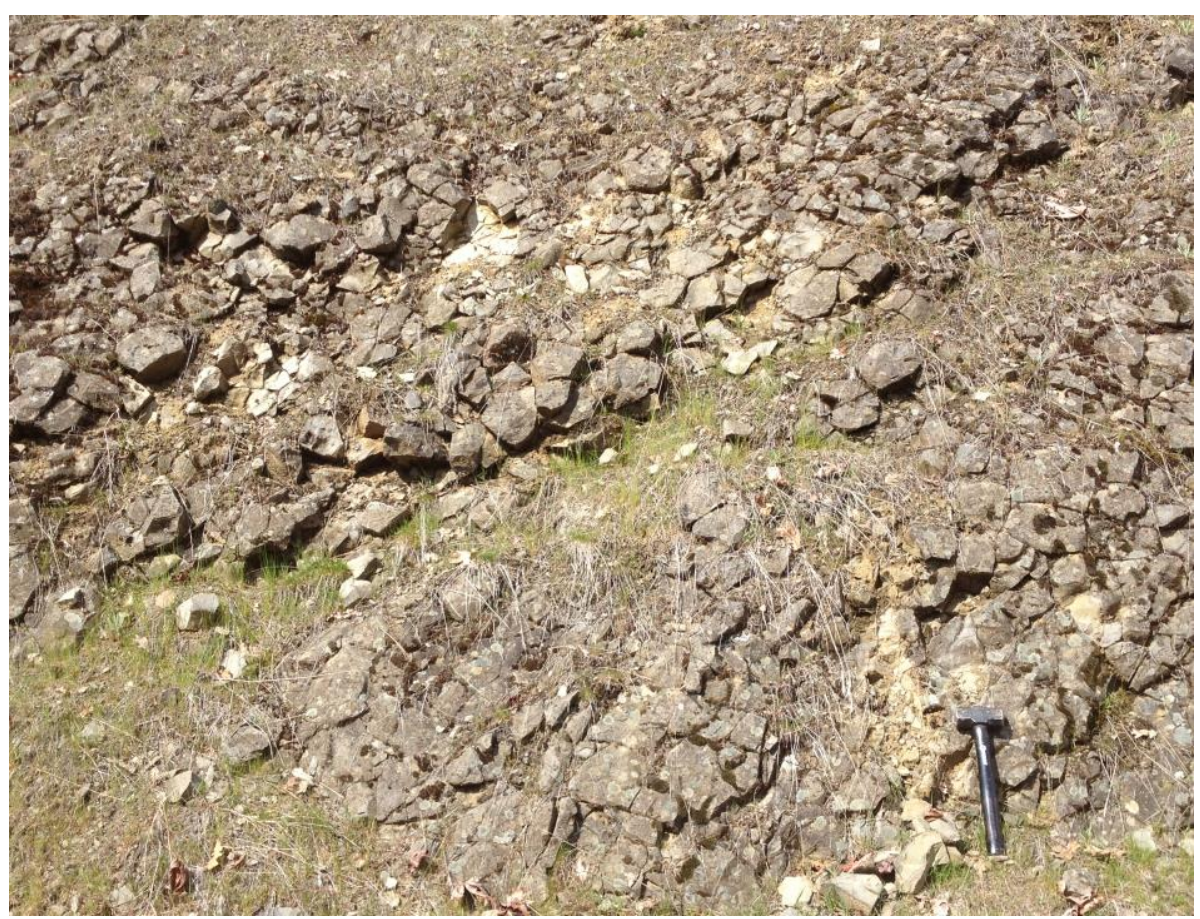

Figure 10: Steeply dipping hackly entablature within the hanging wall of the Rocky Prairie thrust fault along Huskey Rd.

There is a northwest trending fault forming a low-flow boundary between Mosier Creek and Rowena Creek (Figure 7). Lite and Grondin (1988) suspect this fault to be a low permeability boundary because the hydraulic gradient differs on either side of this fault. On the Mosier Creek (southwest) side the groundwater flow direction is to the northwest; whereas on the Rowena Creek (northeast) side of the fault, groundwater flow trends northeast (Lite and Grondin, 1988, plate no. 4).

Two other significant structural features, the Maupin Wrench Fault and the Chenoweth thrust fault (Figure 7), are south of the West Fork Mosier Creek confluence. The Maupin wrench fault is a northwest trending fault, the trace of which crosses Mosier Creek $4.5 \mathrm{~km}$ upstream from the confluence of West Fork 
Mosier Creek. Further south is the Chenoweth thrust fault, approximately $7 \mathrm{~km}$ upstream from the West Fork confluence. This thrust is suspected to serve as a barrier to groundwater flow in much the same manner as the Rocky Prairie thrust fault (Burns, 2012).

\section{Stratigraphic Units and Hydrogeologic Characteristics}

Five important water-bearing units, all part of the Wanapum Formation and Saddle Mountain Formation of the CRBG, have been identified in the Mosier area: the Pomona Member; the Lolo and Rosalia flows of the Priest Rapids Member; and Sentinel Gap and Sand Hollow flows of the Frenchman Springs Member (Lite and Grondin, 1988; Lite, 2013; Swanson et al., 1981). Other aquifers most likely occur at depth in the Frenchman Springs Member (Ginkgo flows) and Grande Ronde Basalt but have not been identified in well logs or drill samples. Figure 11 provides the stratigraphy of the CRBG in the Mosier area, along with associated interbeds. This research continues upon the work of Lite (2013); however, the labeling scheme here differs slightly, so both are included for reference in Figure 11. Rowena Dell provides an excellent vantage point and reference location to view the stratigraphy (Figure 12). To be more concise, often times only the flow name will be referenced throughout this write-up (ex. "Lolo," instead of "Basalt of Lolo.") 


\begin{tabular}{|c|c|c|c|c|c|c|c|}
\hline Epoch & Group & Formation & Member & Label & $\begin{array}{c}\text { Label } \\
\text { (Lite } \\
\text { 2013) }\end{array}$ & $\begin{array}{c}\text { Isotopic } \\
\text { Age }\end{array}$ & $\begin{array}{c}\text { Magnetic } \\
\text { Polarity }\end{array}$ \\
\hline \multirow{5}{*}{ 苋 } & \multirow{5}{*}{ 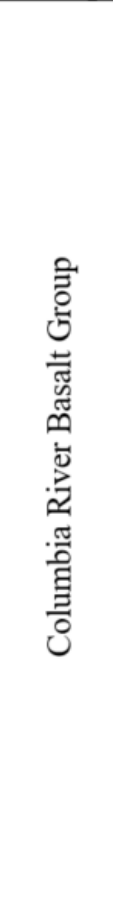 } & $\begin{array}{l}\text { Saddle } \\
\text { Mountains } \\
\text { Basalt }\end{array}$ & $\begin{array}{c}\text { Pomona Member } \\
\text {-Selah Member } \\
\text { interbed }\end{array}$ & Tsp & $\mathrm{Tp}$ & 12 & $\mathrm{R}$ \\
\hline & & \multirow{3}{*}{$\begin{array}{l}\text { Wanapum } \\
\text { Basalt }\end{array}$} & $\begin{array}{l}\text { Priest Rapids Member } \\
\text { (Undifferentiated) } \\
\text { Basalt of Lolo } \\
\text {-Byron Member } \\
\text { interbed } \\
\text { Basalt of Rosalia } \\
\text {-Quincy-Squaw } \\
\text { Creek interbed }\end{array}$ & $\begin{array}{l}\text { Twp } \\
\text { Twpl } \\
\text { Twpr }\end{array}$ & $\begin{array}{l}\text { Tpr } \\
\text { Tprl } \\
\text { Tprr }\end{array}$ & 14.5 & $\begin{array}{l}\mathrm{R} \\
\mathrm{R}\end{array}$ \\
\hline & & & Roza Member & Twr & - & & $\mathrm{T}, \mathrm{R}$ \\
\hline & & & $\begin{array}{l}\text { Frenchman Springs Member } \\
\text { (Undifferentiated) } \\
\text { Basalt of Sentinal Gap } \\
\text { Basalt of Sand Hollow } \\
\text { Basalt of Gingko } \\
\text {-Vantage Horizon } \\
\text { interbed }\end{array}$ & $\begin{array}{c}\text { Twf } \\
\text { Twfsg } \\
\text { Twfsh } \\
\text { Twfg }\end{array}$ & Tf & 15.3 & $\begin{array}{l}\mathrm{N} \\
\mathrm{N} \\
\mathrm{E}\end{array}$ \\
\hline & & $\begin{array}{l}\text { Grand } \\
\text { Ronde } \\
\text { Basalt }\end{array}$ & $\begin{array}{l}\text { Not as of yet identified as an } \\
\text { aquifer in the Mosier area }\end{array}$ & $\mathrm{Tg}$ & - & $\begin{array}{l}15.6 \\
16.5\end{array}$ & $\mathrm{~N}$ \\
\hline
\end{tabular}

Figure 11: Stratigraphy of the Columbia River Basalt Group (CRBG) and associated sedimentary interbeds near Mosier, OR (Modified from Lite and Grondin, 1988; Reidel et al., 2002; Tolan et al., 2009; and Lite, 2013). Magnetic Polarity: Normal (N), Reverse (R), Excursional (E), Transitional (T). Labeling scheme from Lite (2013) is included for reference with figures from his study, which were provided earlier in this write-up. 
Dalles Group / Chenoweth Formation (Tdc)

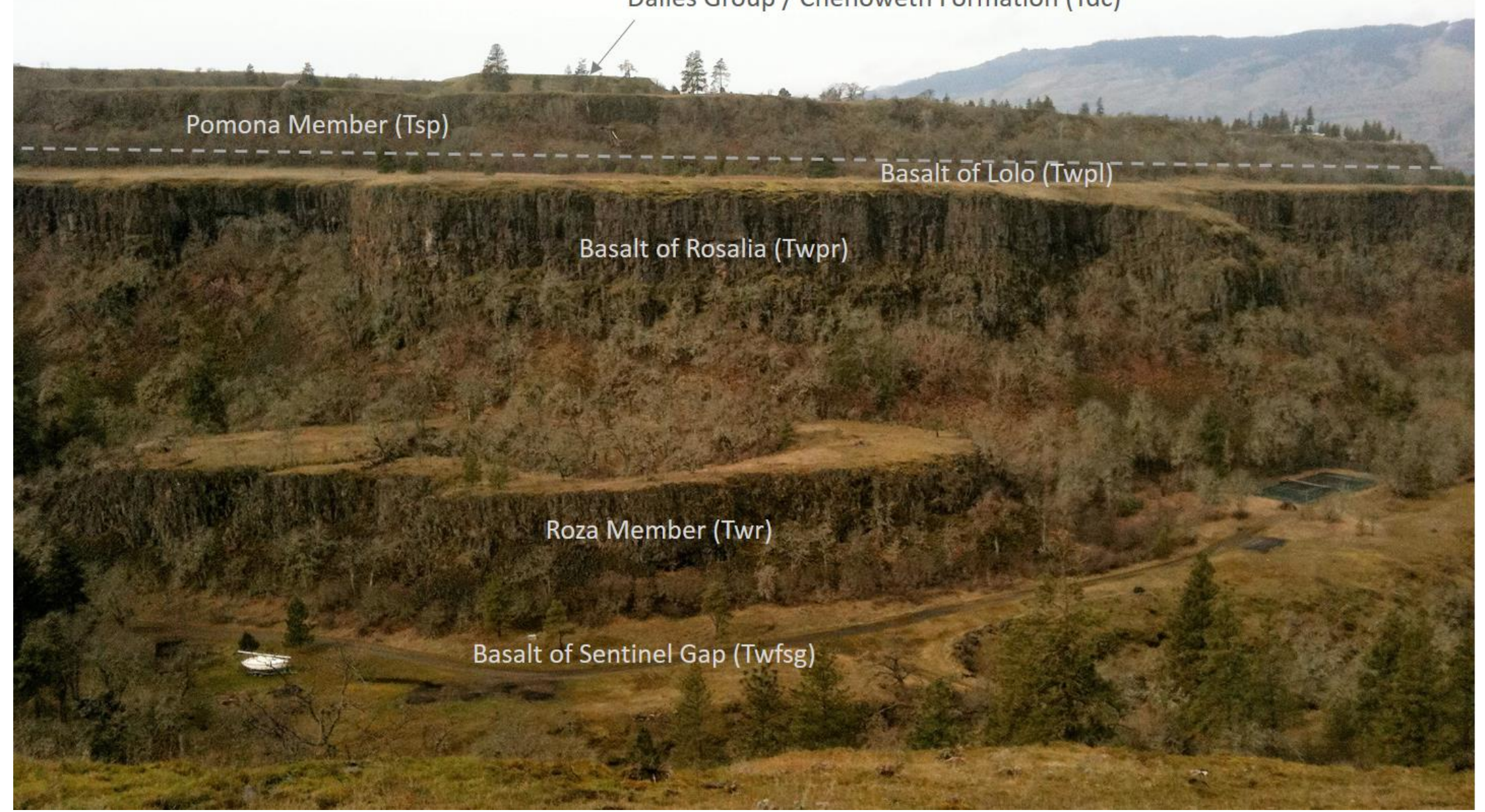

Figure 12: Columbia River Basalt Group stratigraphy exposed in Rowena Dell, looking West from the eastern side of the Dell (modified from Lite and LaMarche, 2014). 
Overlying the CRBG are sedimentary, volcaniclastic, and volcanic deposits of the Dalles Formation, glaciofluvial deposits from the Missoula floods, and fluvial deposits from local streams. Some of these deposits are water bearing, forming discrete aquifers and springs within the Dalles Formation and at the base of the glaciofluvial deposits (Lite and Grondin, 1988; Lite, 2013). The primary focus of this project concerns aquifers within the CRBG but a brief description of these younger sedimentary units are included below. The following unit descriptions are primarily taken from McClaughry et al. (2012), for which I contributed fieldwork and data collection. Hydrogeologic characteristics are based largely on findings and interpretations from Lite (2013).

\footnotetext{
Alluvium

Mosier, Dry, and Rowena Creeks contain Holocene and Anthropocene alluvium consisting of well to poorly sorted and stratified gravel, sand, silt, and clay. These deposits do not cover a significant portion of the mapping area, but have been included along stream beds where appropriate.

\section{Missoula Flood Sediments}

Missoula flood sediments are found in the Mosier area, as floodwaters backed up into canyons adjacent to the Columbia River. Quaternary Missoula Flood (Qgf) sediments occur as silts and sands or gravels. Flood deposits extend up Mosier Creek to at least 3.2 kilometers, up to an elevation of $\sim 207$ m (McClaughry et al., 2012).
} 


\section{Dalles Group / Chenoweth Formation}

The Chenoweth Formation of the Dalles Group (Tdc) is of Cascadian volcanic origin and was deposited on top of CRBG flows in the early Pliocene and late Miocene, with varying degrees of angular unconformity. These deposits consist of debris flow boulder conglomerate, fluvial conglomerate and sandstone, tuffaceous siltstone, pumiceous tuff, lithic tuff, and tuff breccia (McClaughry et al., 2012). Springs were discovered, and one was sampled for this study at the base of this formation; however, the unit is not a heavily utilized aquifer in the Mosier area.

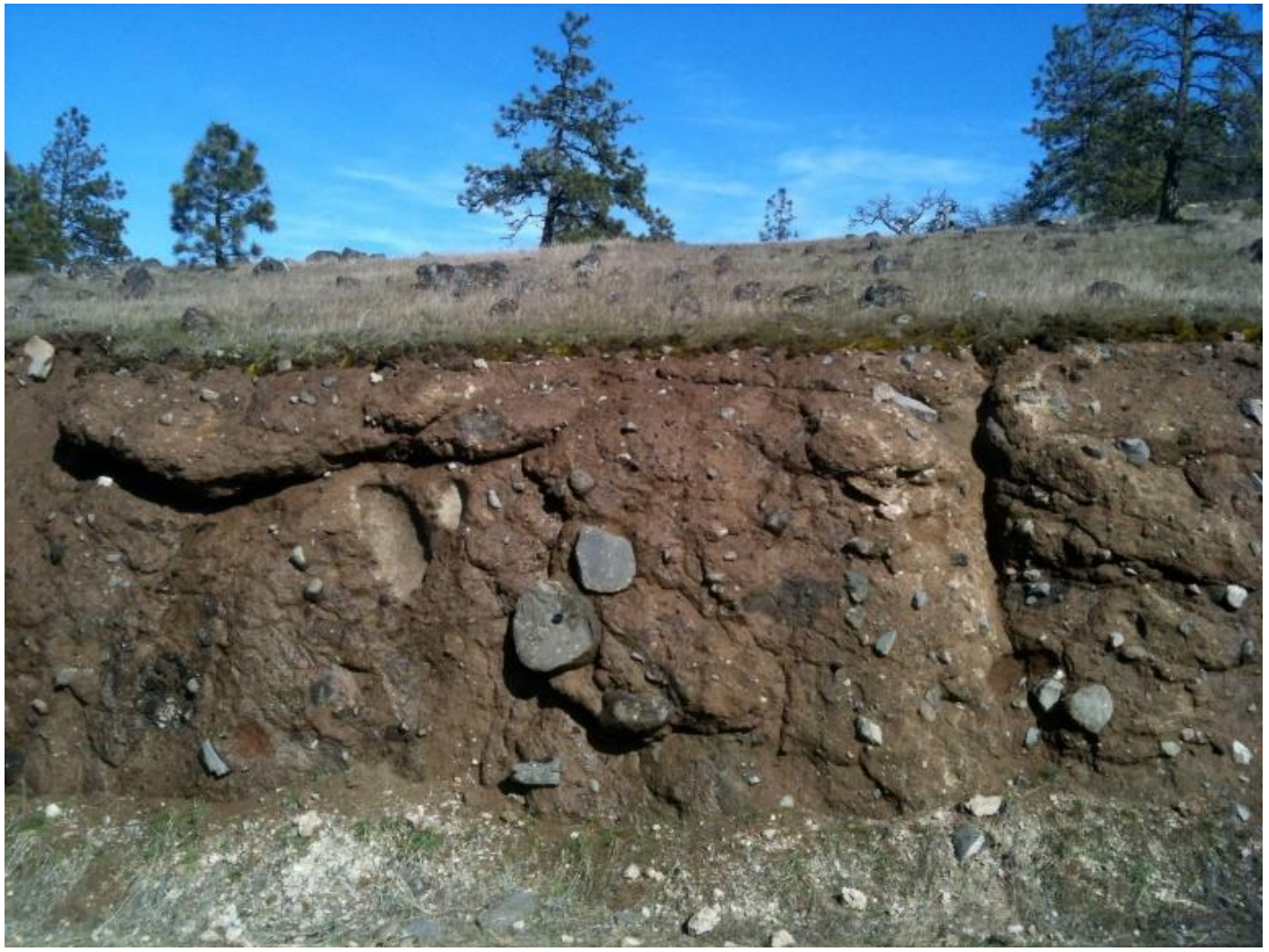

Figure 13: Road cut exposing volcanic debris flow conglomerate of the Dalles Formation in upper elevations of the Mosier Creek watershed. 


\section{Pomona Member of the Saddle Mountains Basalt}

The Pomona Member (Tsp) is typically blue-gray with a fine-grained groundmass that contains abundant acicular and equant plagioclase and olivine microphenocrysts (Figure 14). The Pomona Member consists of 2 to 5 percent white colorless, equant to lath-shaped plagioclase phenocrysts and glomerocrysts, usually less than $5 \mathrm{~mm}$, occurring up to $1 \mathrm{~cm}$ in length (McClaughry et al., 2012). Outcrops of Pomona in the Mosier area are often identifiable by their common entablature-style jointing in narrow (5-20 cm wide) and elongate columns (

Figure 16).

This entablature-style jointing leads to talus slope development consisting of light gray angular fragments up to 15 to $20 \mathrm{~cm}$ across. Locally, upper and lower colonnades are variably vesicular and display massive meter-scale blocky columns. The Pomona flow has a maximum thickness of $60 \mathrm{~m}$ in the Mosier area (Lite, 2013). The flow has reversed magnetic polarity and is assigned a middle Miocene age of 12 Ma (McKee et al., 1977). 


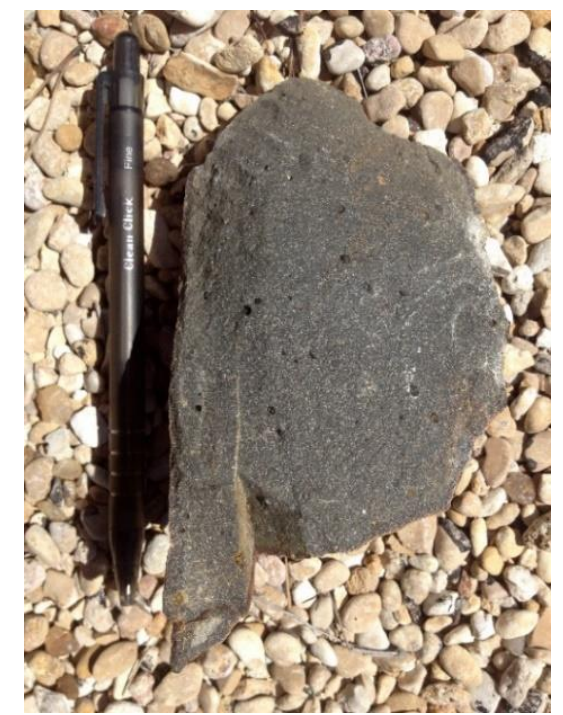

Figure 14: Fresh surface of a Pomona hand sample displaying a fine-grained groundmass.

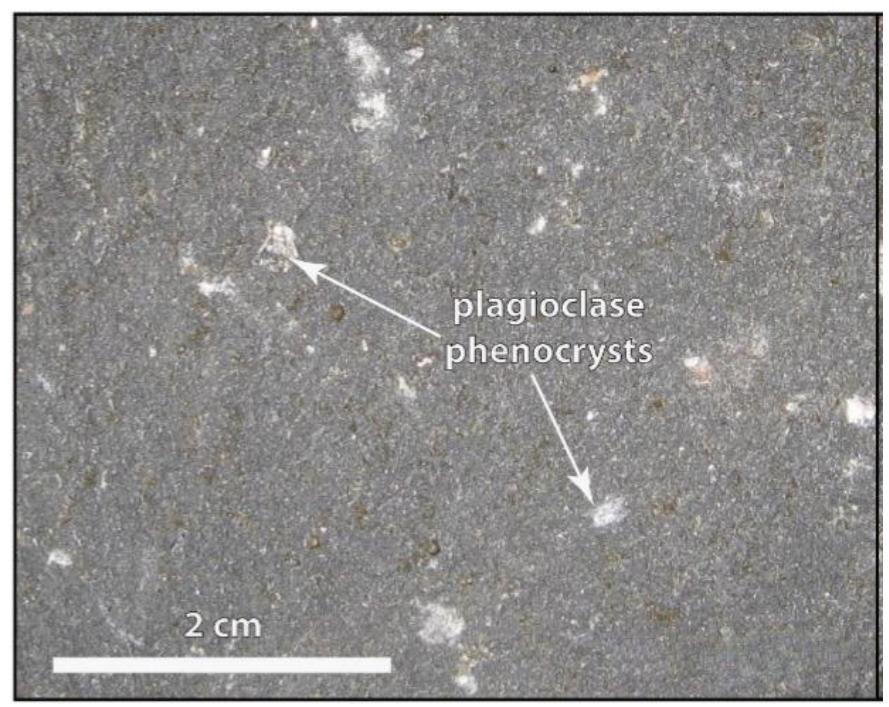

Figure 15: Fine-grained groundmass with sporadic plagioclase microphenocrysts $(<5 \mathrm{~mm})$. Photo is from McClaughry et al., 2012.

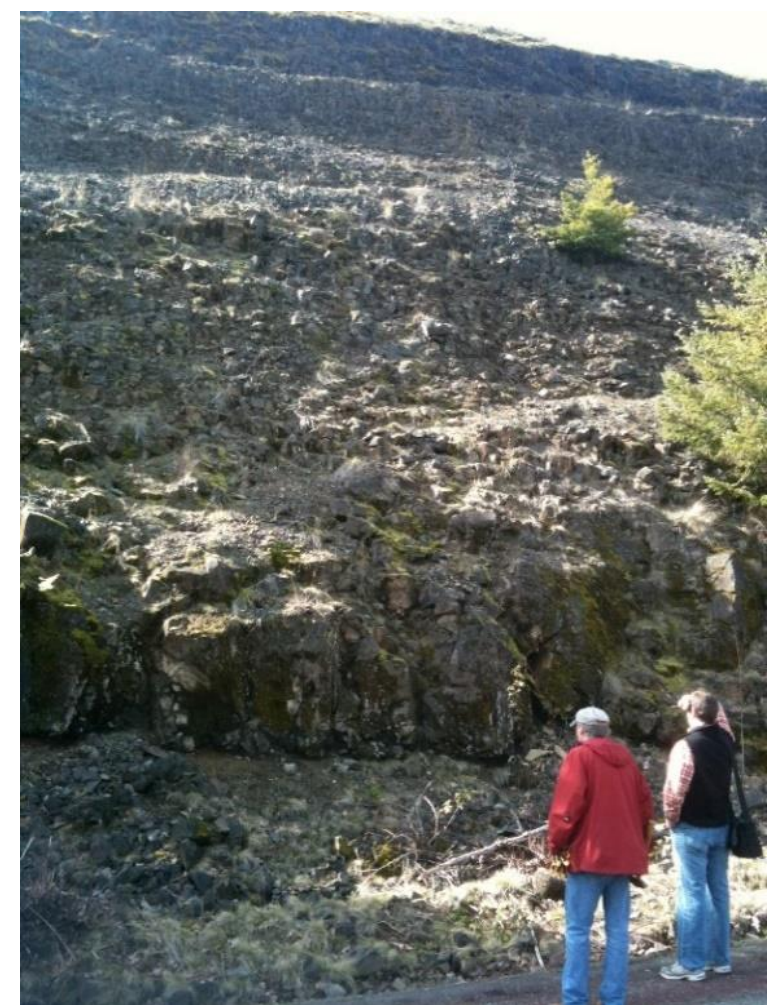

Figure 16: Pomona Basalt outcrop displaying massive columns transitioning upward to commonly seen thin, hackly entablature. 
The Pomona Member was erupted following a period of less frequent CRB eruptions, providing time for canyon incision and sediment deposition. The Pomona flow was largely confined to a paleocanyon whose main channel is north of Mosier and along the axis of the Mosier syncline (Anderson and Vogt, 1987). The portion of the Pomona flow found on the southeast limb of the Mosier syncline exists as lavas which overflowed from the main paleocanyon. The existence of the Selah interbed, which underlies the Pomona flow (described below), is restricted to the Mosier syncline; it is this type of paleoenvironmental detail that largely controls the existence of water-bearing units within the CRBG (Lite, 2013). Permeability within the Pomona flow exists within the lower three to six meters. Lite (2013) explains this is due to the flow's interaction with water in the underlying sedimentary unit at the time of deposition, which created more vesicles and fractures in the base of the flow.

\section{Selah Interbed}

The Selah interbed is often described in driller's logs as "sediment containing clay seams and claystone." The interbed varies in thickness from 0 to $35 \mathrm{~m}$ in the Mosier area and acts as a low permeability boundary between the Pomona and Lolo flows (Lite, 2013). Lite (2013) cites head measurements made during construction of City of Mosier Well Number Four (WASC 51497) as evidence of this boundary; head elevations of 53.6 and $95.7 \mathrm{~m}$ (amsl) were measured in the Pomona and Lolo aquifers, respectively. 


\section{Priest Rapids Member of the Wanapum Basalt}

The Wanapum Basalt in the Mosier area consists of the Priest Rapids, Roza, and Frenchman Springs Members. These members are described below.

\section{Basalt of Lolo}

The upper flow of the Priest Rapids member, underlying the Pomona Member, is the Basalt of Lolo (Twpl). This flow is sparsely plagioclase phyric with a fine to medium-grained groundmass composed of plagioclase, pyroxene, and olivine (McClaughry et al., 2012) (Figure 17 and Figure 18). The existence of plagioclase phenocrysts up to $1 \mathrm{~cm}$ in length can be an important means to differentiate the Basalt of Lolo from the Basalt of Rosalia but this differentiation is not reliably seen in all outcrops.

The flow is relatively thin, from $0-17 \mathrm{~m}$, in the Mosier area with an average of $9-12 \mathrm{~m}$ (Lite, 2013). Weathered outcrops are light to rusty brown with a welldeveloped colonnade and platy sections (McClaughry et al., 2012). In the Mosier area, the Lolo flow may also display massive columns (Figure 19). The Basalt of Lolo is assigned an age of 14.5 Ma (Watkins and Baksi, 1974).

The Lolo flow hosts a prominent aquifer near Mosier. The aquifer exists in the lower three meters of the flow due to development of pillows through the interaction with water at the time of emplacement (Lite, 2013). The pillow lava is exposed in a recent road cut near Mosier on the north side (upthrown block) of the 
Rocky Prairie thrust fault (Figure 20), which at depth would constitute the established water-bearing portion in the study area.

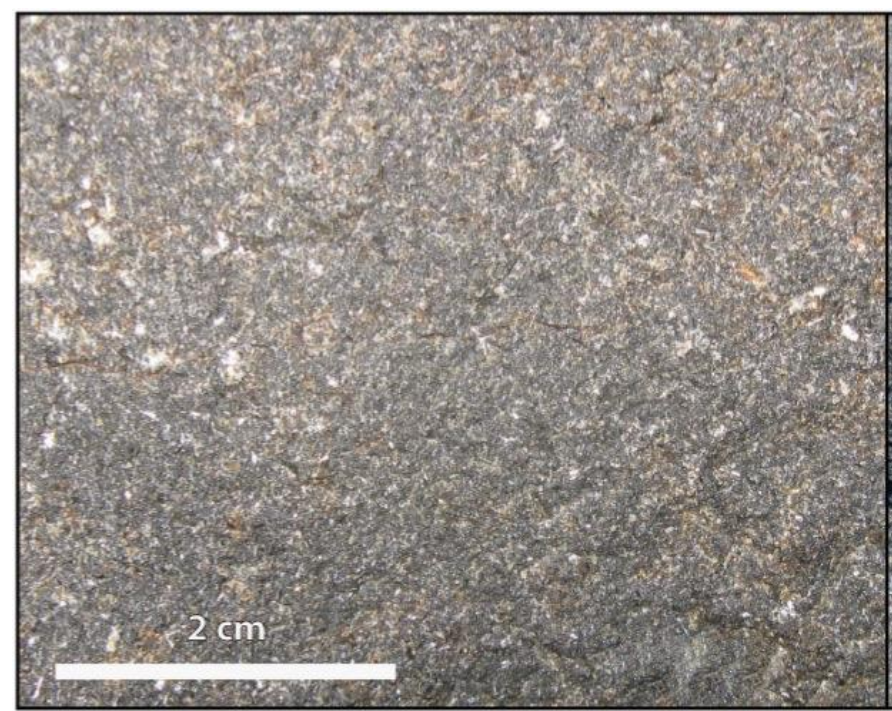

Figure 17: Close-up photo of Lolo in sample Gage 2 collected from within Mosier Creek (McClaughry et al., 2012).

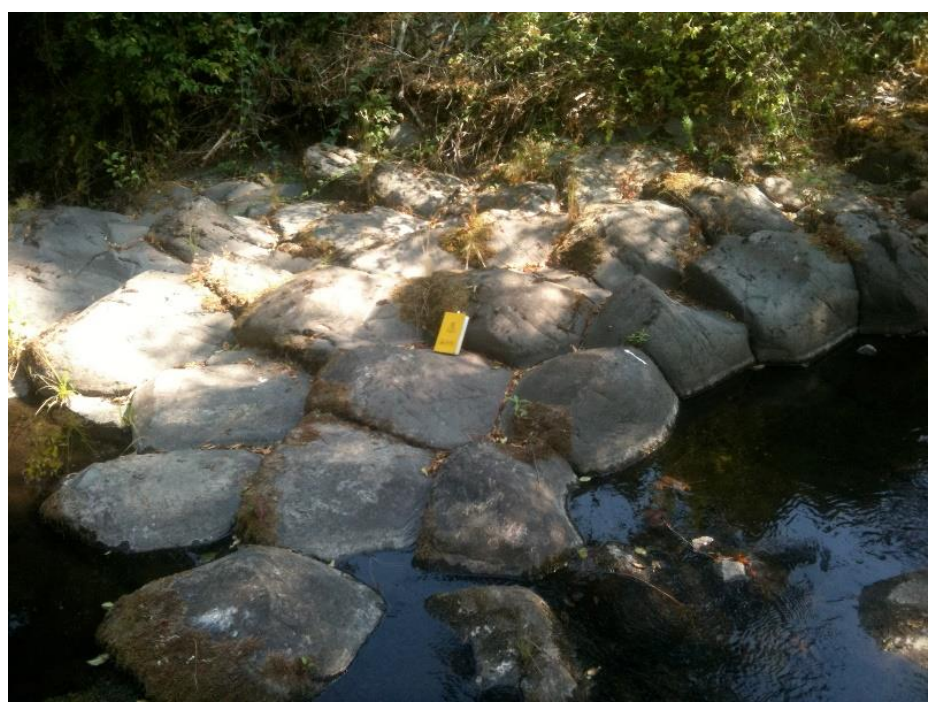

Figure 19: Massive columns of the Lolo flow, smoothed and rounded by Mosier Creek.

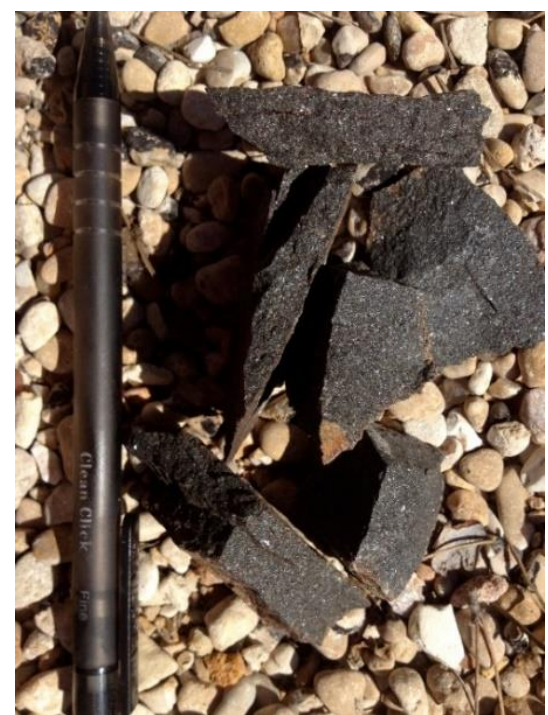

Figure 18: Lolo hand sample showing a medium-grained groundmass and platy appearance.

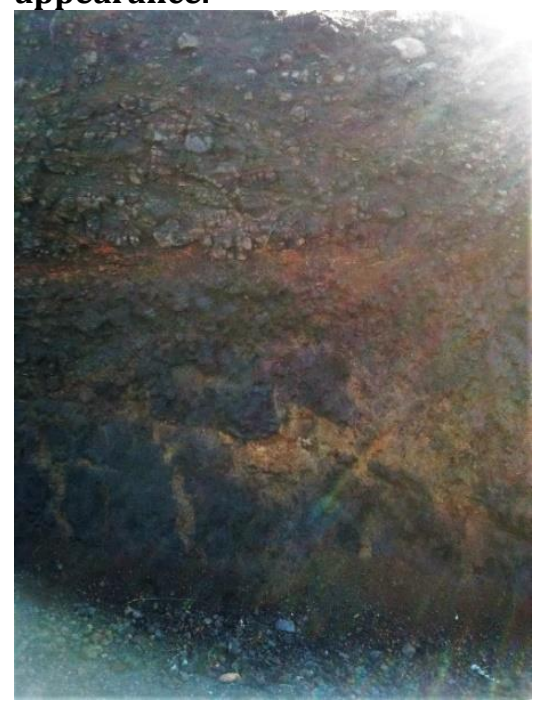

Figure 20: Pillow lava at the base of Lolo flow exposed in a road cut near Mosier, $0 R$. 


\section{Byron Member Interbed}

Locally, the Lolo flow is underlain by a thin interbed, the Byron Member of the Ellensburg Formation. Although difficult to differentiate from the Lolo in driller's logs due to the localized pillow lava found at the base of the Lolo, the thickness of the interbed is up to $2 \mathrm{~m}$ and described as a clay layer.

\section{Basalt of Rosalia}

The Basalt of Rosalia (Twpr) is dark gray and predominantly aphyric with a fine to medium grained groundmass (Figure 21). Yellow plagioclase phenocrysts, 3 $\mathrm{mm}$ to $1 \mathrm{~cm}$ across, are uncommon but can be found sparsely distributed through the unit (McClaughry et al., 2012).

In the Mosier area, the Basalt of Rosalia is present as an intracanyon flow and as overflow deposits. Anderson and Vogt (1987) explain the lithological difference between the two exposures. Intracanyon flows typically have a more quenched finegrained texture and hackly-jointed entablature making up more than 95 percent of the flow thickness. Overflow deposits are relatively more coarse-grained with blocky columnar jointing and localized platy exposures.

The Basalt of Rosalia provides the Mosier area with most of its larger yielding water-bearing zones (Lite, 2013). The Rosalia flow varies from $0-60 \mathrm{~m}$ in thickness with most wells penetrating the upper 15 to $21 \mathrm{~m}$, tapping only the flow top. 


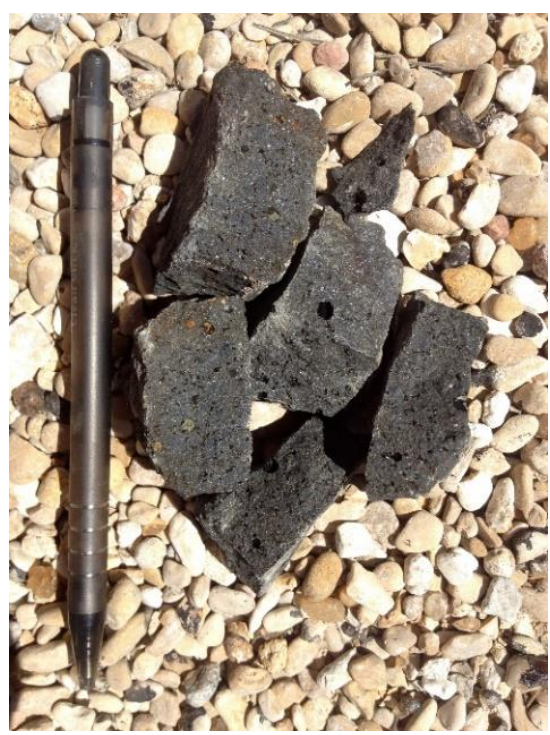

Figure 21: Basalt of Rosalia in hand sample showing fine to medium-grained groundmass and vesicles, some with secondary mineralization (left).

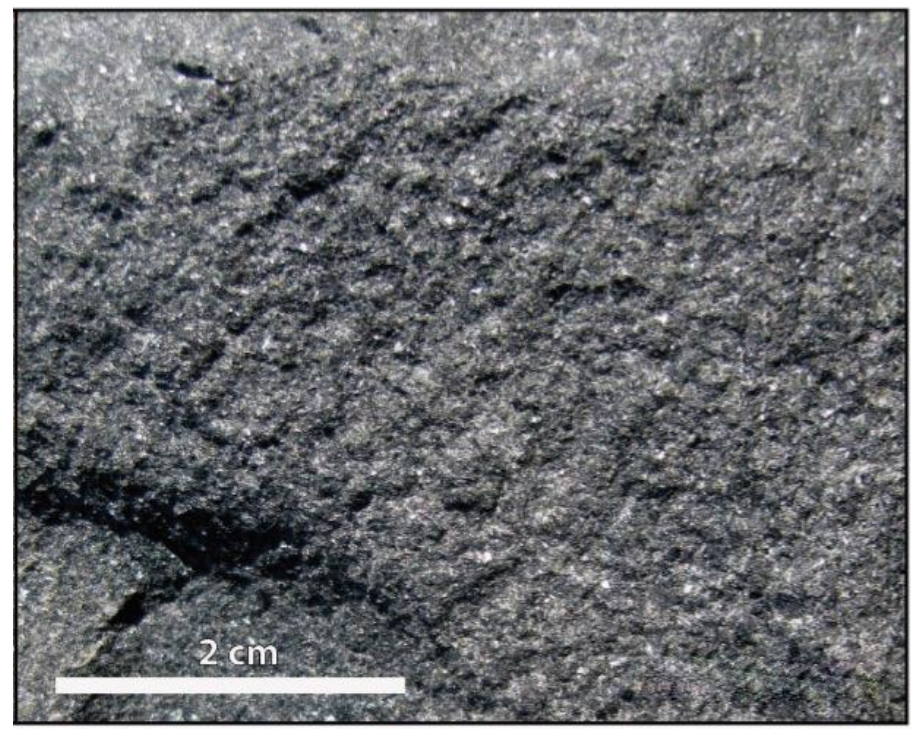

Figure 22: Medium-grained aphyric groundmass of the Basalt of Rosalia (McClaughry et al., 2012).

\section{Quincy-Squaw Creek Interbed}

The Rosalia flow is underlain by an interbed assigned to either the Quincy or Squaw Creek interbed of the Ellensberg Formation. The interbed, a clay layer, can be up to $8 \mathrm{~m}$ thick and is often described in driller's logs as containing "lignite."

\section{Roza Member of Wanapum Basalt}

The Roza Member (Twr) is easily distinguished due to its numerous and uniform plagioclase phenocrysts with single crystals averaging more than $5 \mathrm{~mm}$ in length (Figure 23) (Swanson et al., 1979). However, the Roza Member is not found west of Rowena Dell and does not constitute an aquifer in this study area. Where present, in Rowena Dell for this study area, the Roza provides an important marker bed between the Priest Rapids and Frenchman Springs Members (Lite, 2013). 


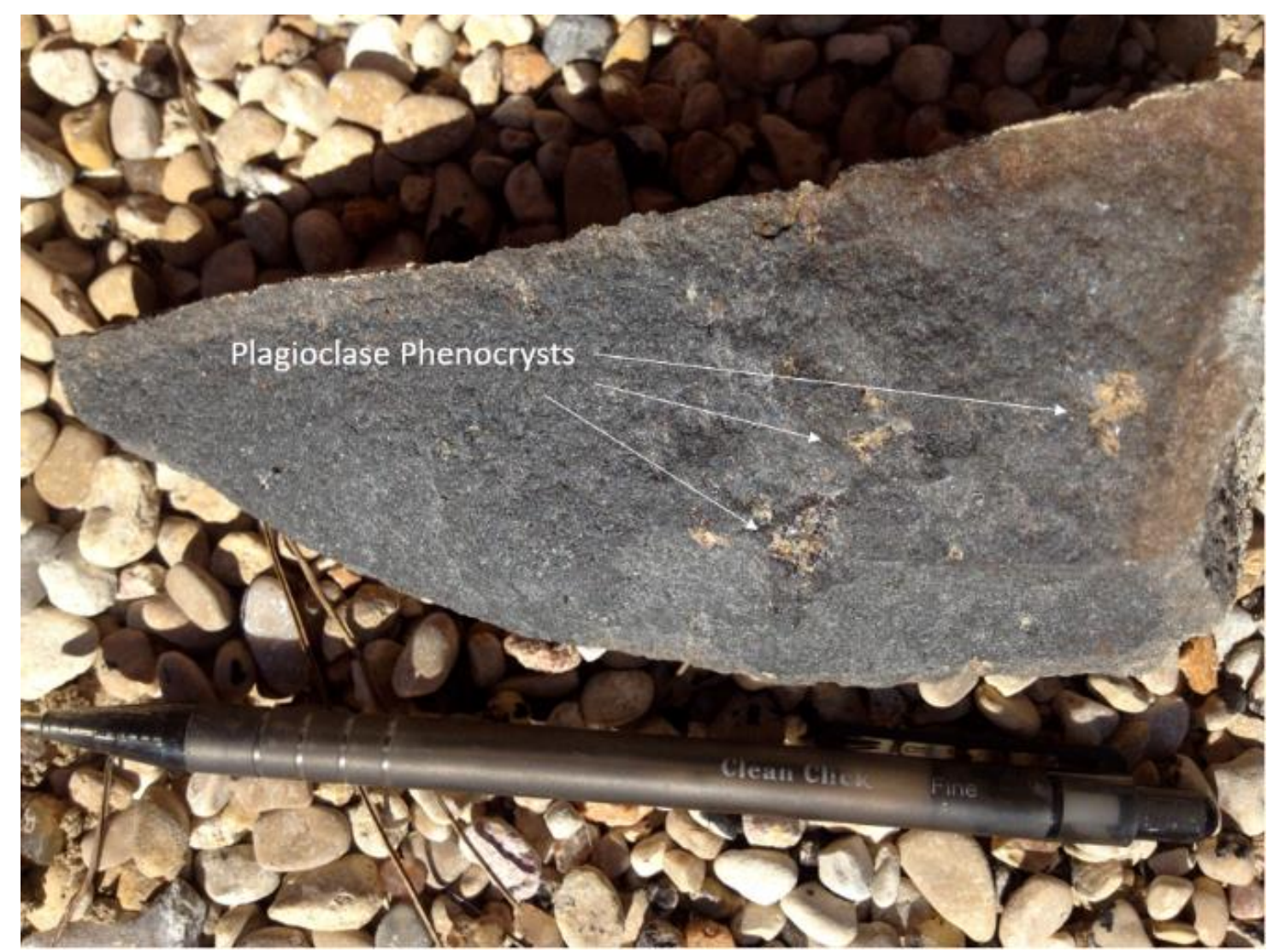

Figure 23: Roza Member in hand sample displaying prominent plagioclase phenocrysts making it an important marker bed, where present. It is only present in Rowena Dell for this study area.

\section{Frenchman Springs Member of the Wanapum Basalt}

The Frenchman Springs Member (Twf) makes up the lower 3 to 5 individual flows of the Wanapum Basalt. From youngest to oldest the Frenchman Springs consists of the Basalt of Sentinel Gap, Basalt of Sand Hollow, and Basalt of Gingko. These flows are present throughout the study area at depth but only crop out in Rowena Dell and the upper reaches of Mosier Creek, closer to the axis of the Columbia Hills anticline. 


\section{Basalt of Sentinel Gap}

A prominent cliff former in Rowena Dell, the Basalt of Sentinel Gap (Twfsg), is distinguished from the younger Priest Rapids Member because its magnetic polarity is normal. McClaughry et al. (2012) describe these outcrops as 0.2 to $2 \mathrm{~m}$ thick vesicular flow lobes; they can also occur as vertical platy jointing or irregular colonnade jointing. Typically, the Sentinel Gap is black and aphyric with a medium grained groundmass (Figure 24 and Figure 25).

The Sentinel Gap has a thickness of $33 \mathrm{~m}$ in one area well and forms an aquifer, at times with artesian flows (Lite, 2013).

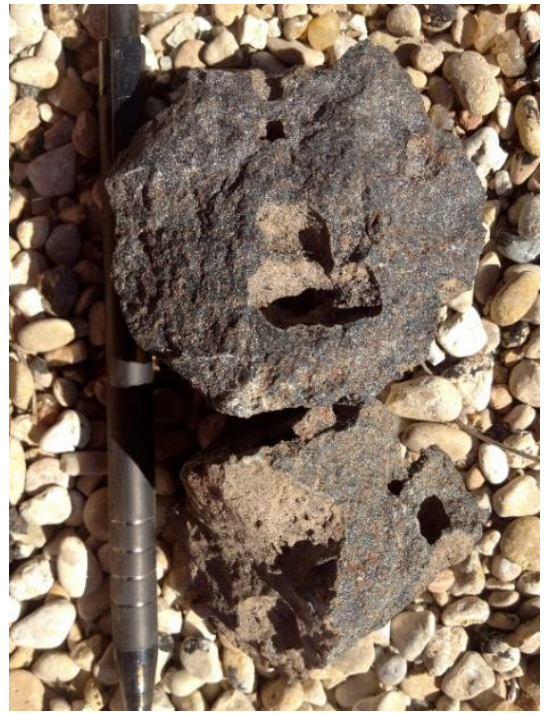

Figure 24: Hand sample of a vesicular flow top within the Sentinel Gap flow of the Frenchmen Springs Member.

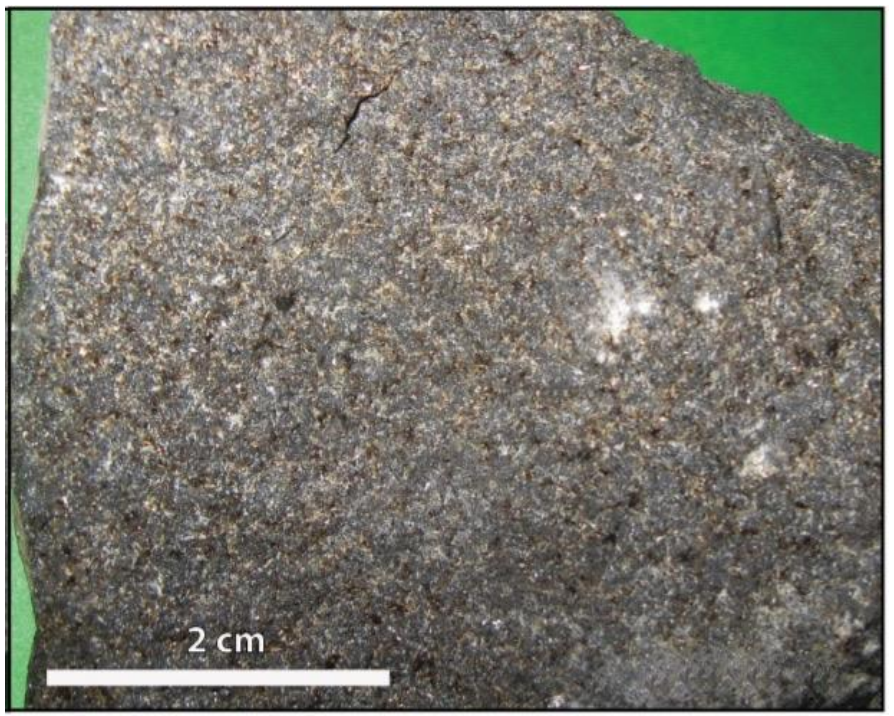

Figure 25: Representative hand sample of Sentinel Gap flow interior with fine to medium-grained groundmass and rarely plagioclase phyric (McClaughry et al., 2012). 


\section{Basalt of Sand Hollow}

Sand Hollow (Twfsh) consists of at least 2 flows separated by a $1 \mathrm{~m}$ black and red porous zone (Lite, 2013). The upper flow is dark gray with a medium-grained groundmass, consisting of sparse plagioclase phenocrysts and glomerocrysts less than $2 \mathrm{~cm}$ in length (Figure 26) (McClaughry et al., 2012). The lower flow is similar in appearance to the upper flow but typically contains smaller $(<1 \mathrm{~cm})$ plagioclase phenocrysts. The full thickness is estimated to be $70 \mathrm{~m}$, based on an area well log. Although not utilized extensively, a few wells do penetrate an upper water-bearing portion of the Sand Hollow Unit (Lite, 2013).

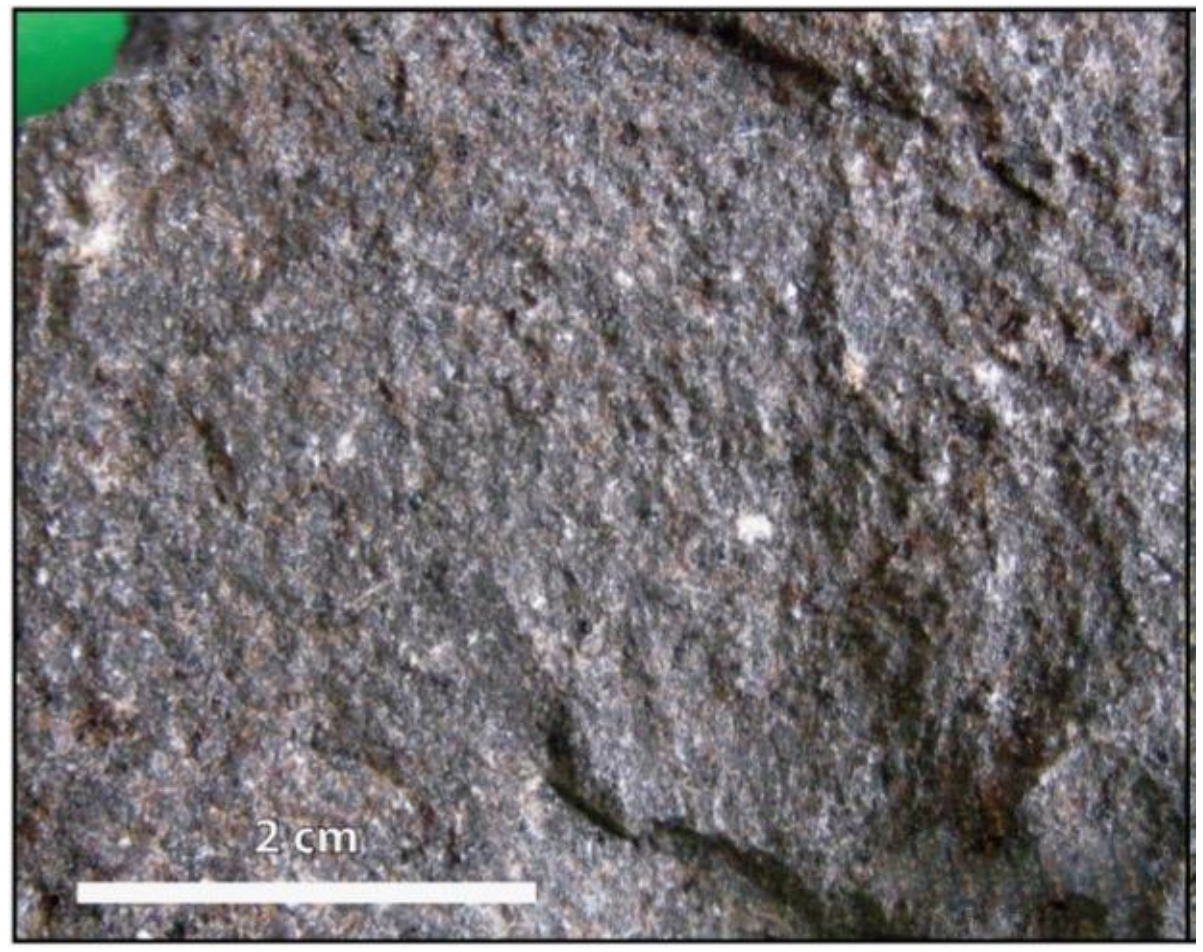

Figure 26: Representative hand sample of Sand Hollow flow displaying a finegrained groundmass, which is sparsely plagioclase phyric (McClaughry et al., 2012). 


\section{Basalt of Ginkgo}

The Basalt of Ginkgo (Tg) has not yet been identified as an aquifer in the orchard tract area of Mosier and does not crop out in the current study area.

Underlying the Basalt of Ginkgo is the Vantage Horizon, separating the Frenchman Springs Member from the Grand Ronde Basalt. 


\section{Chapter 2- Surface and Subsurface Geologic Mapping}

\section{Introduction}

Lite (2013) postulates that the aquifer discharge elevation for Pomona and Lolo flows in Mosier Creek is controlling the lower limit of hydraulic head observed in area wells (Fig. 4). Detailed geologic mapping of the major aquifer-forming flows along Mosier Creek was the first step in testing Lite's hypothesis. The regional scale geology is relatively well understood; however, previous studies have not been carried out with enough detail to distinguish between the Priest Rapids flows of Lolo and Rosalia, instead only mapping the Priest Rapids Member as undifferentiated. Additionally, the exact location and elevation where the waterbearing portion of the flows are exposed within the creek have not been identified. Of most importance to this study is the water-bearing portion of Lolo and Pomona flows.

The identification of CRB aquifer forming flows in the subsurface was also essential. The hydrochemical analysis component of this study required a detailed analysis of area wells in order to distinguish which wells are suitable for water sampling, based on the aquifers encountered at depth. To guide the water sampling portion of this project, XRF analysis from well-cuttings coupled with well log interpretations were used in identifying CRB flows in area wells.

Dry Creek and Rowena Creek are not perennial streams, as is Mosier Creek; thus, they are not the main focus of this project. However, geologic mapping along 
Dry and Rowena Creeks was completed to locate springs and determine from which CRB flows they issue. Water sampling was conducted in an attempt to single out hydrochemical signatures imparted on the waters from the host rock.

\section{Methods}

USGS 1:24,000 scale topographic maps were used to record geologic data during field mapping. Mosier, Dry, and Rowena Creeks are covered by two quadrangles, White Salmon, WA-OR and Lyle, WA-OR. The best available elevation data was a USGS 10-meter digital elevation model (DEM). A handheld Garmin E-Trex GPS device was utilized to record location data in the North American Datum of 1983 (NAD 83). Geologic data were digitized, organized, and analyzed using ArcGIS' ArcMap and ArcCatolog software. ArcMap was utilized for map creation and to assign elevation data from the $10 \mathrm{~m}$ DEM to GPS data points. The most current National Agriculture Imagery Program (NAIP) digital orthophotos were utilized as well. The orthophotos are especially useful in the Mosier area because the geologic contacts and/or interflow zones can be identified via linear bands of vegetation.

An important tool to verify field-based CRB flow identification is the X-ray fluorescence (XRF) geochemical analysis of whole rock samples. Many CRB flows are too fine grained and glassy to differentiate based on texture and composition alone. XRF analysis provides a chemical means to flow-by-flow map CRB, owing to the homogeneity of individual flows across their extent, despite their huge volumes 
(Hooper, 2000). Figure 27 shows Lite's (2013) identifications of flow units in the Mosier area based on their groupings on a $\mathrm{TiO}_{2}$ vs. Cr variation diagram. The identification of units via XRF data for this study follows Lite's interpretations and determinations were made solely on the basis of $\mathrm{TiO}_{2}-\mathrm{Cr}$ concentrations.

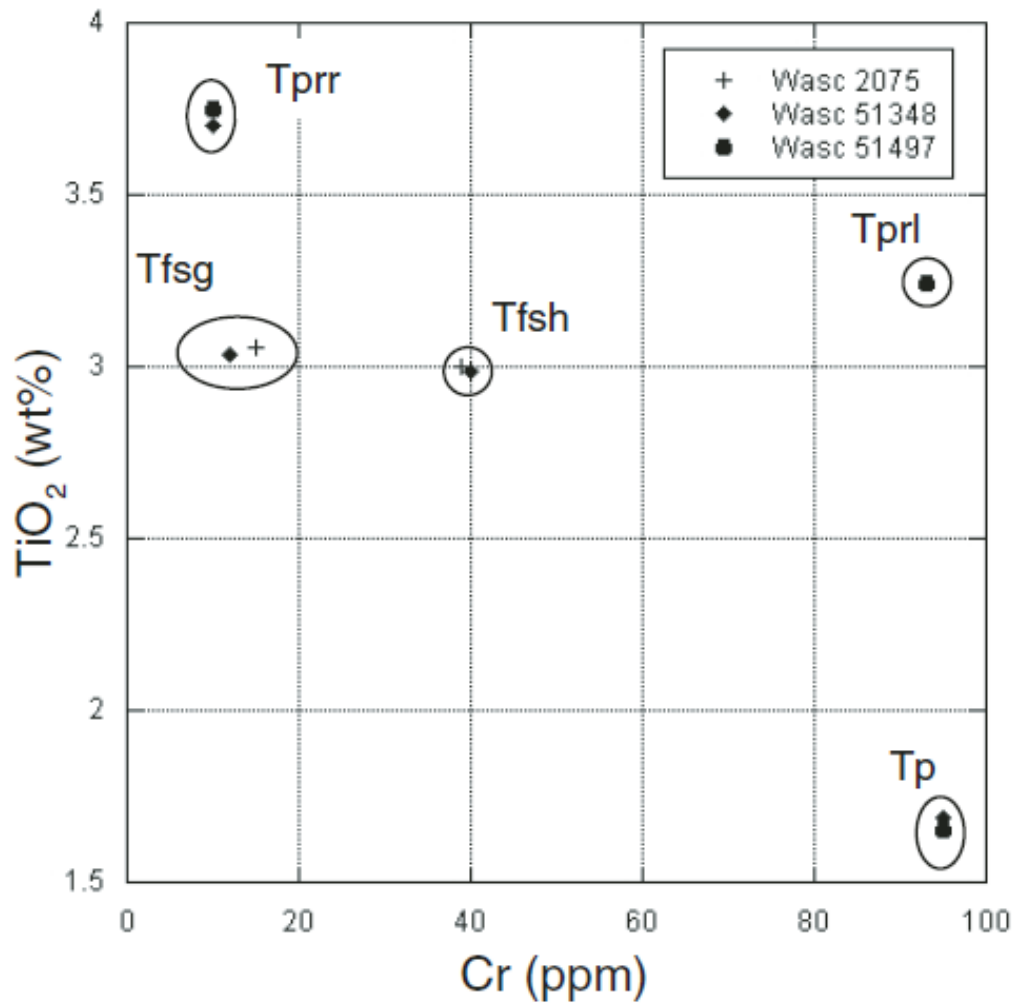

Figure 27: CRBG flow identification in the Mosier area via chemical analysis of rock cuttings utilizing $\mathrm{a} \mathrm{TiO}_{2}$ vs. Cr variation diagram (Lite, 2013). Units: Tp: Pomona, Tprl: Lolo, Tprr: Rosalia, Tfsg: Sentinel Gap, Tfsh: Sand Hollow.

Hand samples were collected in the field, and only the least weathered samples were analyzed. Therefore, only samples representing the dense interior of flows were sent in for analysis, if possible. In addition to field collected hand samples, well cuttings were used to identify subsurface geology. Cuttings from six boreholes in the project area were attained from Ken Lite of the Oregon Water 
Resources Department (OWRD). These cuttings were washed and dried, logged, and prepared for geochemical analysis. Hand samples that were collected for XRF analysis followed the naming convention with the first three letters of the property owner's last name and a number signifying the sequential order of collection. Wellcuttings were labeled with the county abbreviation, WASC, followed by the 4-digit state well number.

Whole-rock chemical analysis was completed through the Washington State University GeoAnalytical Laboratory. Methods and analytical procedures conducted at the Washington State University GeoAnalytical Laboratory are described by Johnson et al. (1999) and can be found at http://www.sees.wsu.edu/Geolab/note/xrf.html. Major element determinations are normalized to a 100 -percent total on a volatile-free basis and recalculated with total iron expressed as FeO. Microsoft Excel was utilized to organize and analyze the geochemical data.

Using the XRF-based interpretations of hand samples and well cuttings as controls, the hydrostratigraphy of additional wells were interpreted from waterwell reports (or logs) available through the OWRD website (http://apps.wrd.state.or.us/apps/gw/well $\log /$ ). Although the well logs are not always a reliable means to identify CRB flows at depth, they can be an important tool in estimating flow depths and thicknesses based on sedimentary interbeds and water-bearing units described in the well logs (Figure 28). Surface elevations allow 
depths to be translated to subsurface elevations, which provides an additional control in interpreting units via comparison to elevations inferred from field mapping and XRF-based identification of units in other area wells. Well logs are also useful in that they contain well constructions details imperative to determining which aquifers are "open" to the well, meaning which aquifers potentially contribute water to the well. Well logs from sixteen wells were chosen for an in-depth interpretation and have been included in Appendix C. Well location is to be discussed further in Chapter 3, but wells were chosen to represent a variety of locations and depths from lower to upper Mosier Creek, mainly within the OWRD Administrative Area (or orchard tract).

A handheld digital magnetometer was used to measure natural remnant magnetization or magnetic polarity. This can be used in the project area to differentiate the Frenchman Springs Member from younger flows because the former has normal polarity, and younger flows have reverse polarity. The magnetic polarity of each flow was provided in Figure 11.

\section{Subsurface Geology Results XRF Analysis of Well-Cuttings}

Sixteen well logs were analyzed to develop a better understanding of the subsurface geology and to identify wells that were suitable for water sampling based on both the aquifers they reach and well construction. Seven of these were 
analyzed along with well cuttings obtained through Ken Lite of the OWRD. Of those seven wells with cuttings, twenty-three samples were sent in for XRF analysis, representing various depths within the wells (Figure 29).

All major aquifer-forming flows were successfully identified through XRF analysis. Figure 29 displays evident groupings in a $\mathrm{TiO}_{2} \mathrm{vs}$. $\mathrm{Cr}$ variation diagram that are sufficient to differentiate between these flows. Locations for the wells are provided in Figure 30. All well locations are described, in addition to the latitude and longitude, by their approximate distance upstream from the inferred location of the Rocky Prairie thrust fault (Figure 7), which serves as the major flow boundary for the groundwater system (Newcomb, 1969; Lite and Grondin, 1988). The importance of this fault as it relates to the groundwater flow system was previously described in the section entitled, "Groundwater Flow System and Tectonic Structures." 


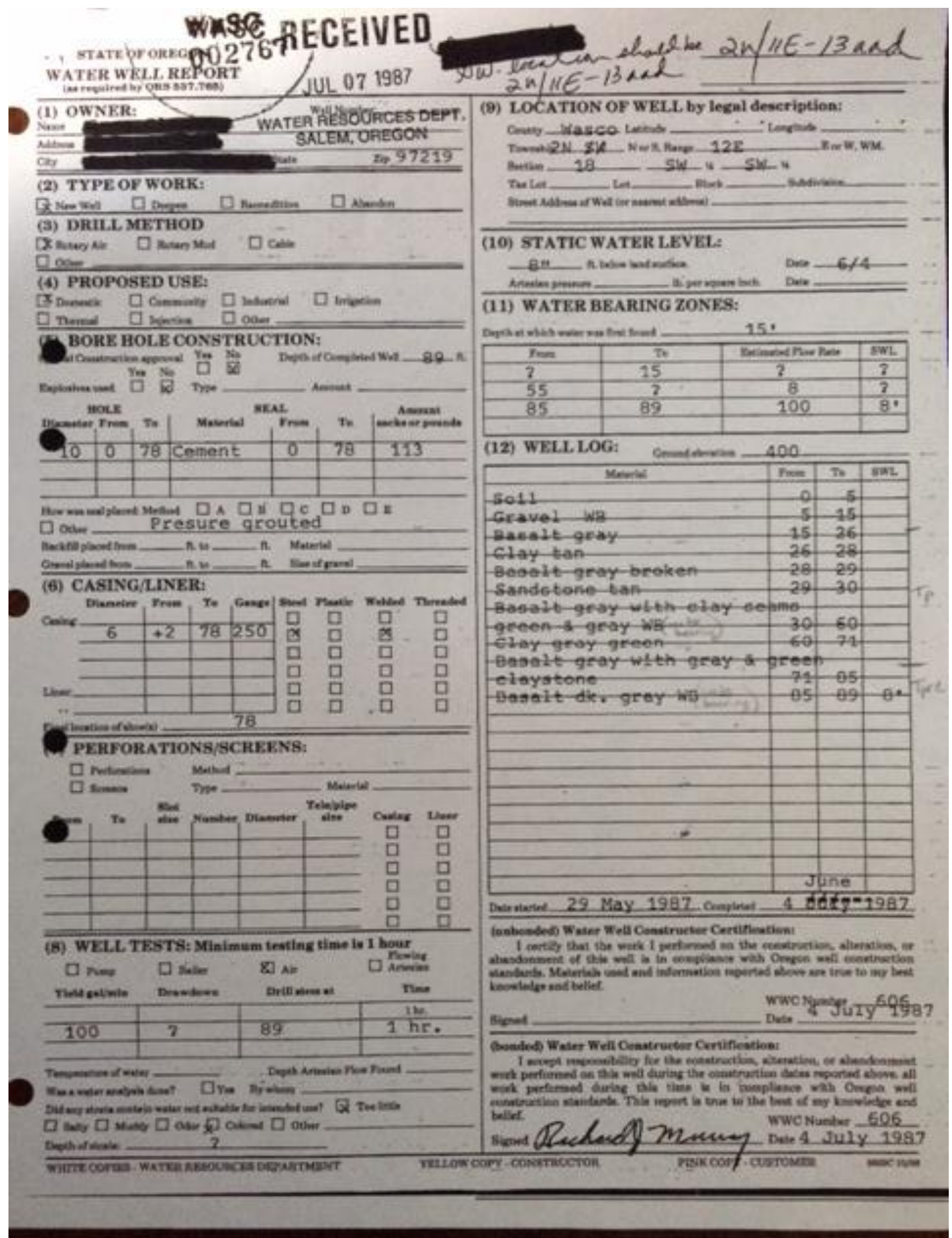

Figure 28: An example well log where driller's notes, describing water-bearing units and sedimentary interbeds, can help identify and estimate the thickness of subsurface CRBG flows. Well construction details were also utilized to determine which aquifers could potentially contribute water to the well. 


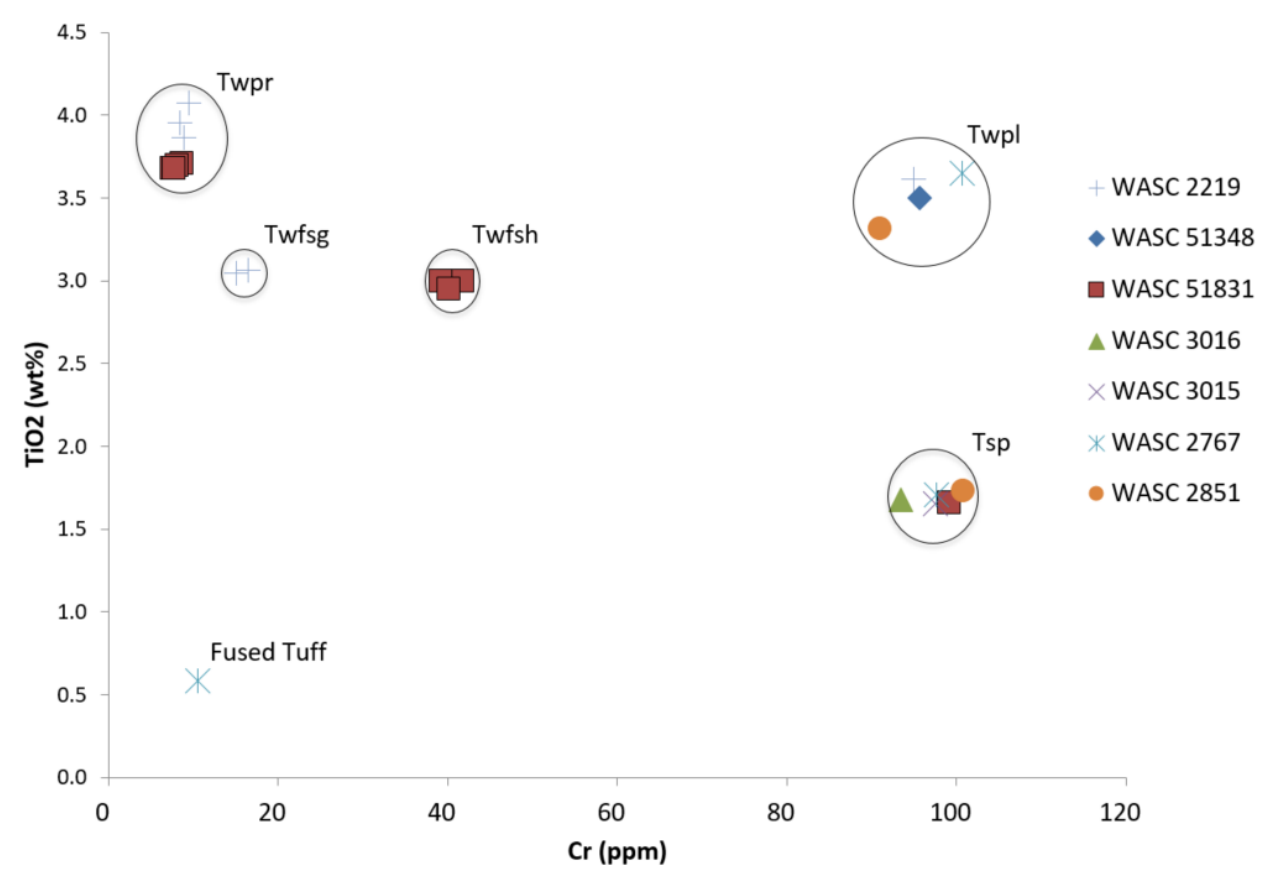

Figure 29: XRF analysis results for all well cuttings. Tsp: Pomona, Twpl: Lolo, Twpr: Rosalia, Twfsg: Sentinel Gap, Twfsh: Sand Hollow.

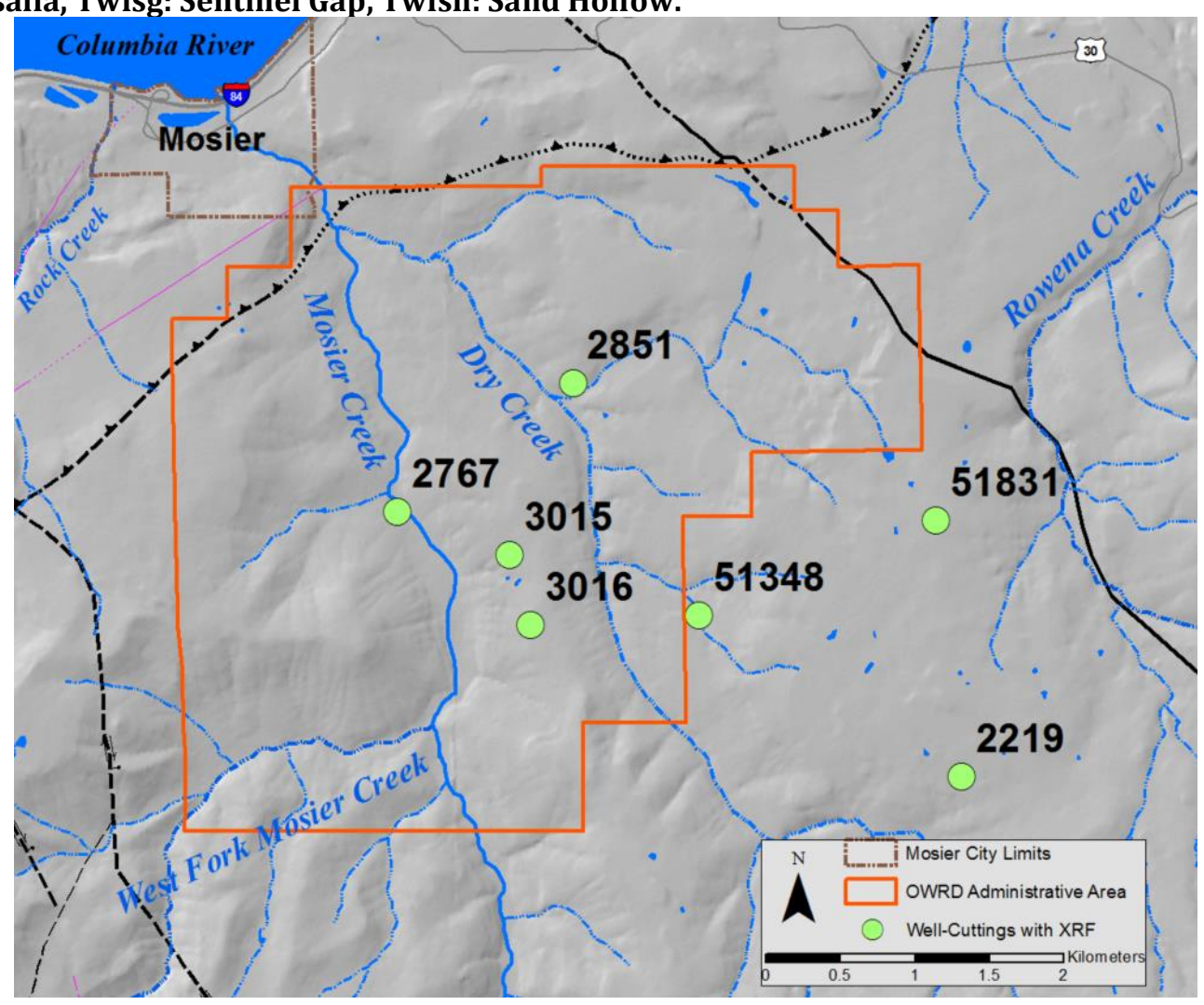

Figure 30: Mosier area wells for which units were identified via XRF analyses of cuttings. 
WASC 2851 is located on the east side of Dry Creek roughly $1.97 \mathrm{~km}$ upstream (south-southeast) from the Rocky Prairie thrust fault. Land surface elevation at the well is approximately $148.4 \mathrm{~m}$ (amsl). Originally, this well was constructed with a casing installed to 6 meters and a completion depth of $45.4 \mathrm{~m}$ (WASC 2855). WASC 2851 is a well report for a deepening of the well to $59 \mathrm{~m}$ in 1987. In 1992 the well was deepened to a depth of $70.4 \mathrm{~m}$ (WASC 2035). XRF analysis was obtained for two samples from depths of $53.3 \mathrm{~m}$ and $59.4 \mathrm{~m}$ representing the Pomona Member and the Basalt of Lolo of the Priest Rapids Member respectively (Figure 31).

WASC 2767 is located along Mosier Creek, roughly $1.94 \mathrm{~km}$ upstream from the Rocky Prairie thrust fault. Land surface at the well is approximately $101.5 \mathrm{~m}$ (amsl). The well report indicates that WASC 2767 was cased and sealed to $23.8 \mathrm{~m}$, with a completion depth of $27.1 \mathrm{~m}$. Three samples were obtained from this well from depths of 7, 20.7, and $25.3 \mathrm{~m}$. Interpretation of XRF data indicates the 7 and $25.3 \mathrm{~m}$ samples represent the major aquifer forming flows of the Pomona Member and Basalt of Lolo (Figure 31).

An interesting side note is the sample from $20.7 \mathrm{~m}$ from WASC 2767; it represents an airfall vitric tuff deposited as a result of volcanic activity between the time of deposition of the Lolo and Pomona flows. It is for this reason, the $\mathrm{TiO}_{2}$ and $\mathrm{Cr}$ values for the sample do not fall within one of the established groupings of the major aquifer forming flows for this area (Figure 29). The tuff was welded, or fused, 
from contact with the Pomona flow as it was emplaced, due to heat and pressure, and was aided by heat transfer due to existence of water vapors (Schmincke, 1965). Additionally, the relative increase in permeability at the base of the Pomona is thought to be related to the interaction between the tuff and the basalt in areas where the basalt burrowed into the tuff and fragmented it, which formed pepperites (Schmincke, 1965).

WASC 3015 is located on the ridge between Mosier and Dry Creeks, approximately $2.51 \mathrm{~km}$ upstream (south-southeast) from the Rocky Prairie thrust fault. Land surface elevation is $205.7 \mathrm{~m}$ (amsl). This well is cased and sealed to 18.0 $\mathrm{m}$ with a completion depth of $75.0 \mathrm{~m}$. The Pomona flow was identified via XRF analysis at a depth of $67.1 \mathrm{~m}$ (Figure 31).

WASC 3016 is $3.03 \mathrm{~km}$ upstream (south) of the Rocky Prairie thrust fault with a land surface elevation of $246.3 \mathrm{~m}$ (amsl). The well report indicates a seal was placed at $6 \mathrm{~m}$ and is cased to $12.2 \mathrm{~m}$ with a $103.6 \mathrm{~m}$ depth of completion. XRF analysis confirmed the Pomona flow at a depth of $94.5 \mathrm{~m}$ (Figure 32).

WASC 51348 is $3.6 \mathrm{~km}$ upstream (south) of the Rocky Prairie thrust fault. Land surface elevation is $227.7 \mathrm{~m}$ (amsl). The well report indicates it is cased and sealed to a depth of $42.4 \mathrm{~m}$ with a completion depth of $158.5 \mathrm{~m}$. XRF analysis revealed the Lolo flow at a depth of $30.5 \mathrm{~m}$ (Figure 32).

The last well included in Figure 32, WASC 51831, is $4.55 \mathrm{~km}$ southeast of the Rocky Prairie Thrust Fault and $0.83 \mathrm{~km}$ west of Rowena Creek, at an elevation of 
$389.5 \mathrm{~m}$ (amsl). This is one of the deeper wells in the area with a completion depth of $269.7 \mathrm{~m}$ and is cased and sealed to $201 \mathrm{~m}$. Seven rock cutting samples were obtained from depths of $131.1 \mathrm{~m}, 140.2 \mathrm{~m}, 149.4 \mathrm{~m}, 160.0 \mathrm{~m}, 184.4 \mathrm{~m}, 227.1 \mathrm{~m}$, and 269.7 m. XRF analysis indicates the flows of Pomona, Rosalia, and Sand Hollow, are present (Figure 32). Interestingly, Lolo and Sentinel Gap were not identified by sampling from WASC 51831.

WASC 2219 is located $5.63 \mathrm{~km}$ southeast of the Rocky Prairie Thrust Fault and has a land surface elevation of $413.0 \mathrm{~m}$ (amsl). It was completed to $245 \mathrm{~m}$ from a deepening in 2002 (WASC 51078); the original well was drilled in 1995. It is sealed to a depth of $21.9 \mathrm{~m}$ and cased to $30.1 \mathrm{~m}$. XRF analysis revealed the flows of Lolo (88.4 m), Rosalia (115.8, 128.0, 131.1, and 140.2 m), and Sentinel Gap (149.2 and $153.9 \mathrm{~m}$ ) (Figure 33). 


\section{WASC 2851}

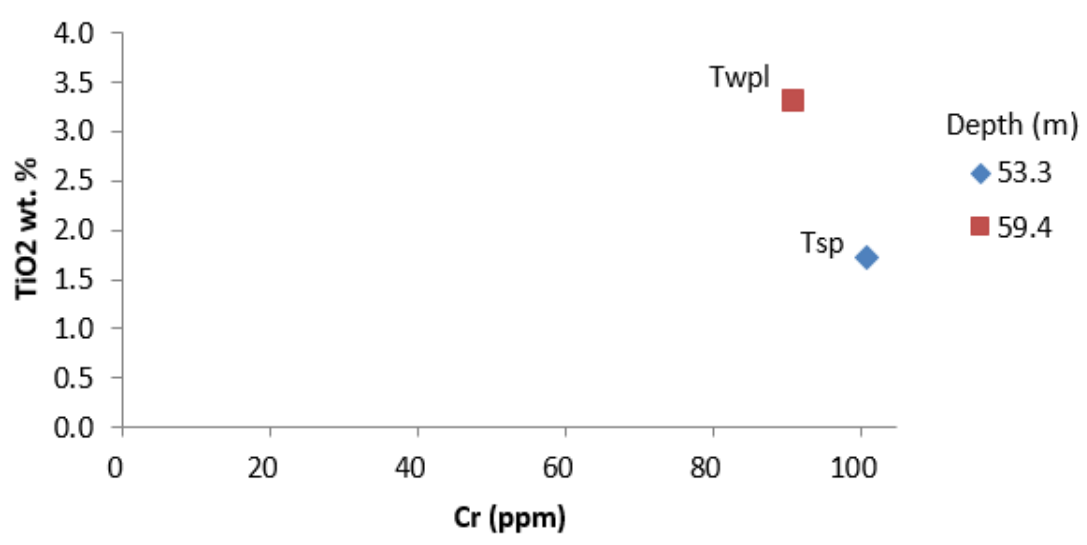

WASC 2767

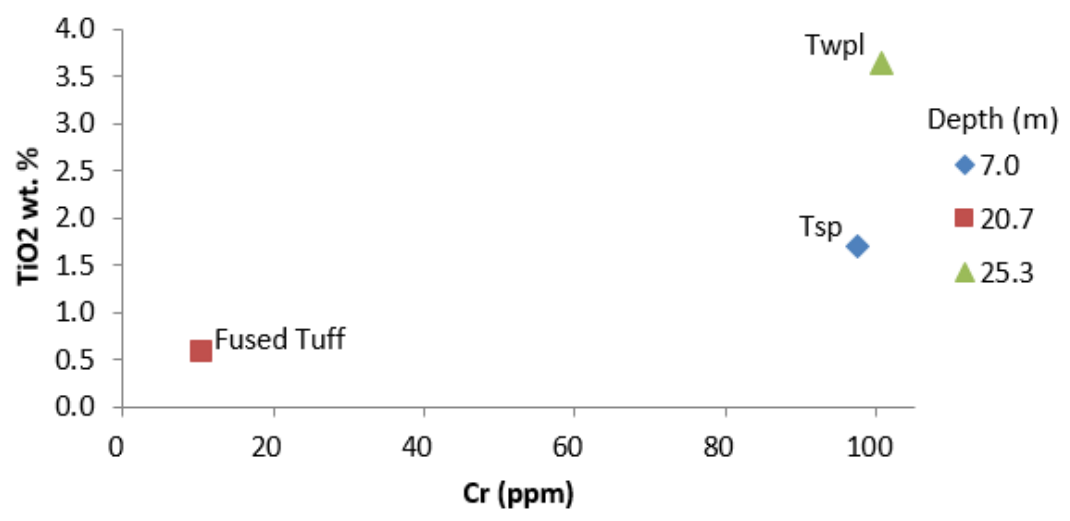

WASC 3015

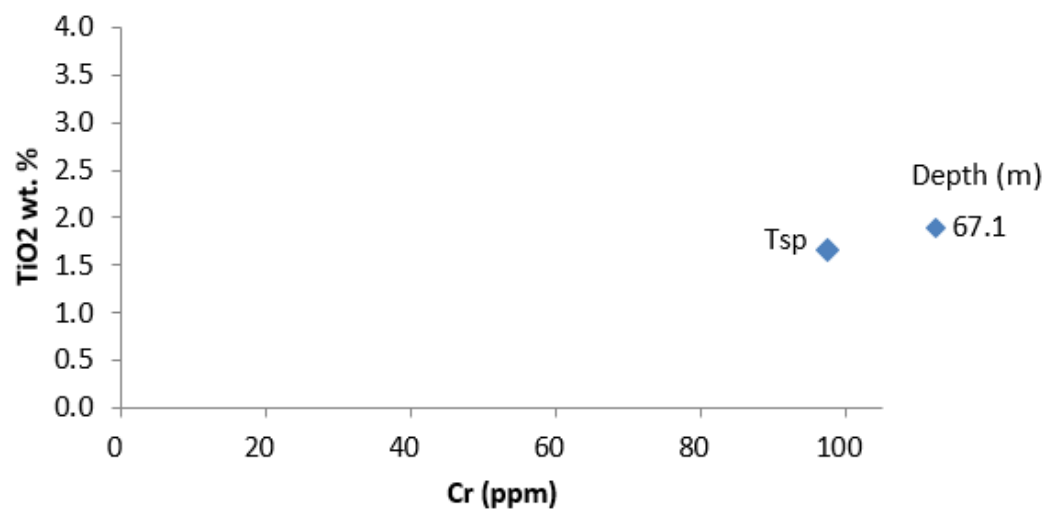

Figure 31: $\mathrm{TiO}_{2}$ vs $\mathrm{Cr}$ variation diagram for each well, displaying the XRF analysis results for well cuttings. $\mathrm{Tsp}=$ Pomona, $\mathrm{Twpl}=\mathrm{Lolo}, \mathrm{Twpr}=$ Rosalia, Twfsg $=$ Sentinal Gap, Twfsh $=$ Sand Hollow . 
WASC 3016

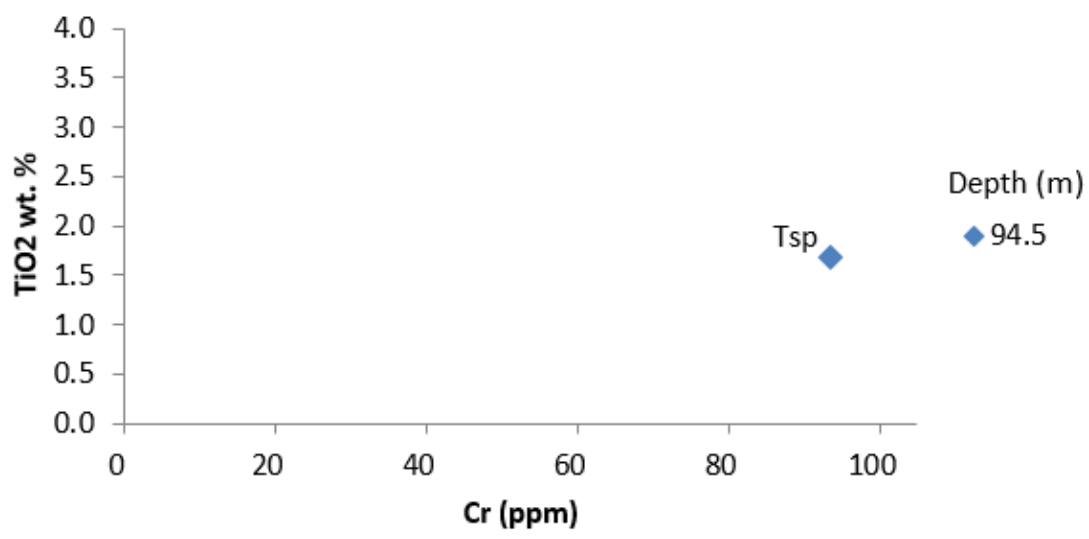

WASC 51348

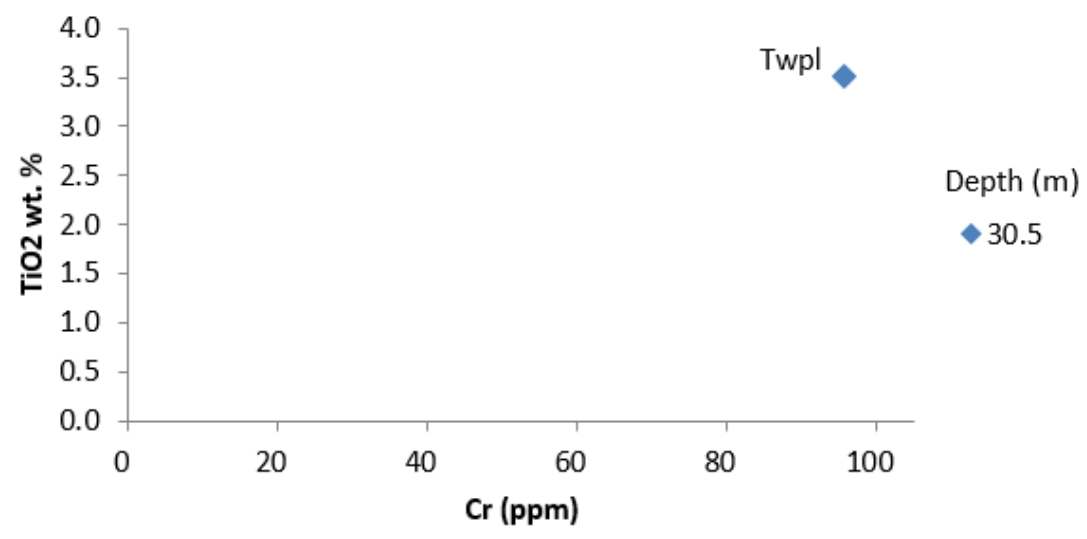

WASC 51831

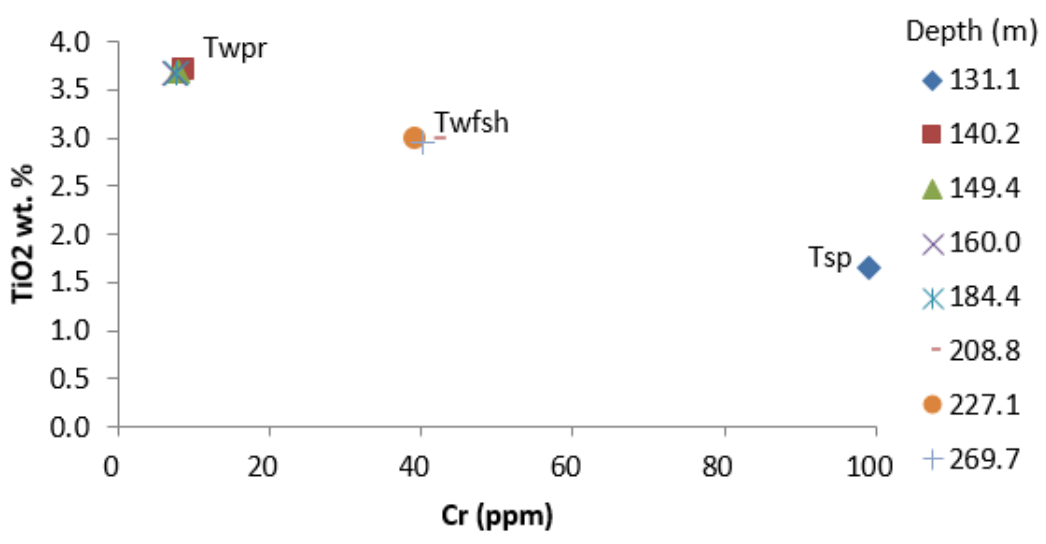

Figure 32: $\mathrm{TiO}_{2}$ vs $\mathrm{Cr}$ variation diagram for each well, displaying the XRF analysis results for well cuttings. $\mathrm{Tsp}=$ Pomona $, \mathrm{Twpl}=\mathrm{Lolo}, \mathrm{Twpr}=$ Rosalia, Twfsg $=$ Sentinal Gap, Twfsh $=$ Sand Hollow . 
WASC 2219

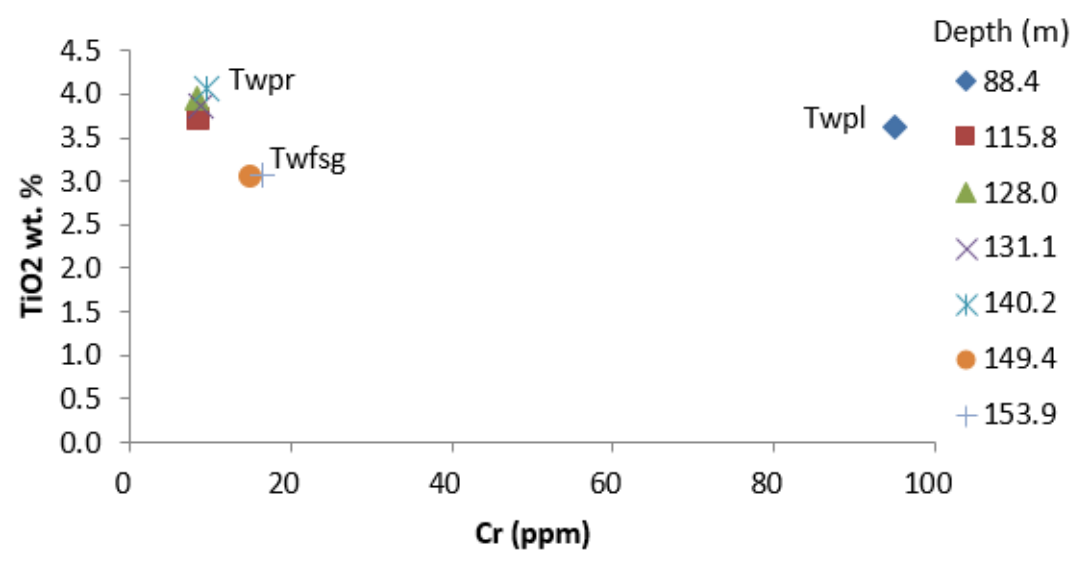

Figure 33: $\mathrm{TiO}_{2}$ vs $\mathrm{Cr}$ variation diagram for each well, displaying the XRF analysis results for well cuttings. $\mathrm{Tsp}=$ Pomona, $\mathrm{Twpl}=$ Lolo, $\mathrm{Twpr}=$ Rosalia, Twfsg $=$ Sentinal Gap, Twfsh $=$ Sand Hollow .

\section{Well Determinations from XRF and Well Log Analysis}

Figure 31 and Figure 33 and Table 1 and Table 2 summarize the hydrostratigraphic interpretations of all the wells examined or sampled in this study, based on the interpretations made for XRF control wells, field mapping and well log descriptions, including contact depths and unit thicknesses. Table 1 and Table 2 include the inferred depth, elevation, and thickness of each geologic unit for each well. The UTM coordinates, elevation of the well, and completion depth/elevation are included as well. The open interval(s) of each well is provided in the last column of the tables. 


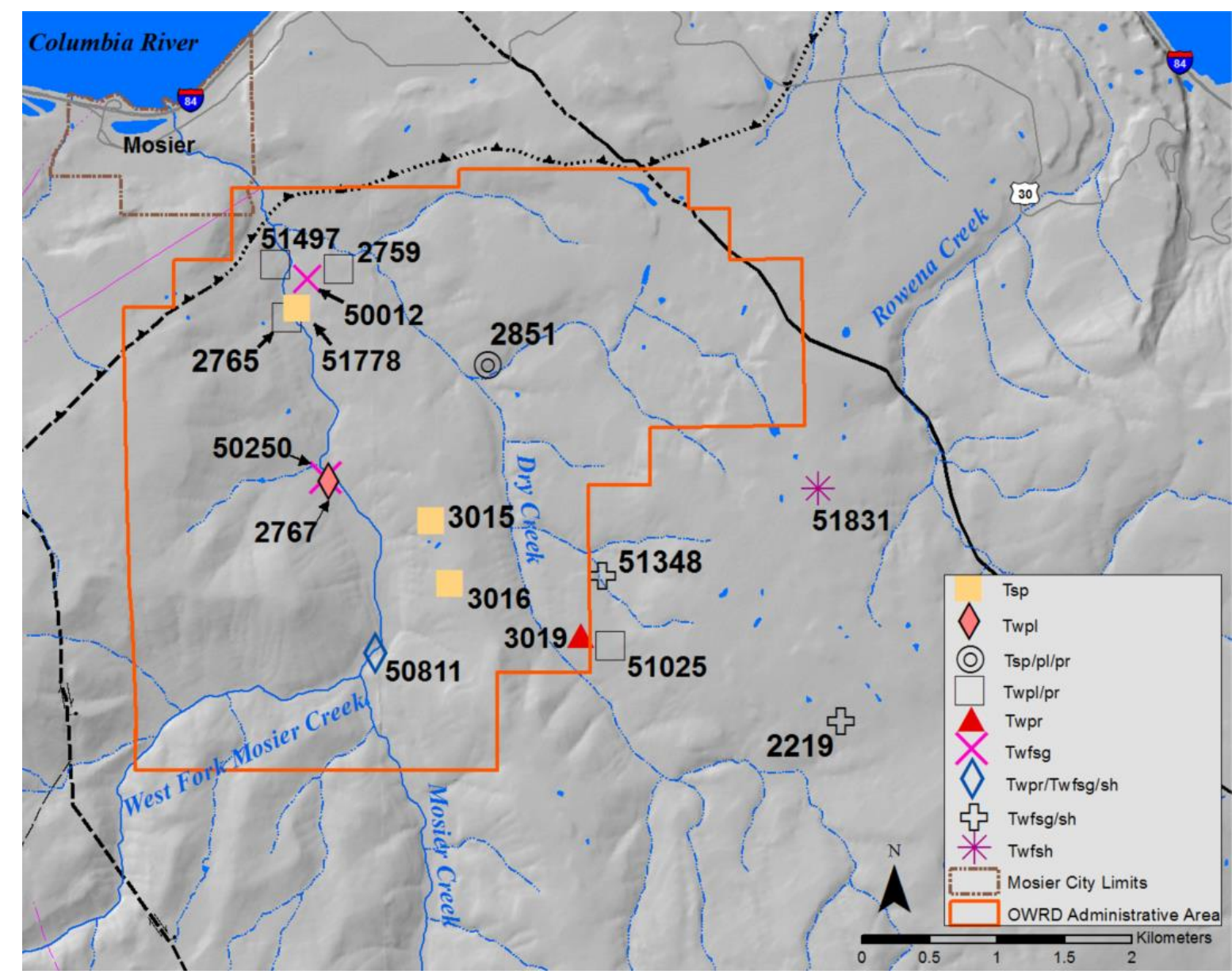

Figure 34: Location map of wells with well log interpretation, well-cutting XRF, and/or water sampling. State Well number is included as the label and the producing aquifer of each well is denoted by the symbol and legend. Tsp: Pomona, Twpl: Lolo, Twpr: Rosalia, Twfsg: Sentinel Gap, Twfsh: Sand Hollow. Wells interconnecting multiple aquifers have more than one aquifer listed in the legend (ex. Twpl/pr: Lolo and Rosalia). 
Table 1: Well log interpretations for wells with XRF control.

\begin{tabular}{|c|c|c|c|c|c|c|c|c|c|c|c|c|}
\hline \multirow[b]{2}{*}{$\begin{array}{l}\text { State Well } \\
\text { Number }\end{array}$} & \multirow[b]{2}{*}{$\begin{array}{l}\text { UTM } \\
\text { Northing } \\
\text { (m) }\end{array}$} & \multirow[b]{2}{*}{$\begin{array}{l}\text { UTM } \\
\text { Easting } \\
\text { (m) }\end{array}$} & \multirow[b]{2}{*}{$\begin{array}{c}\text { Elevation } \\
(\mathrm{m})\end{array}$} & \multicolumn{3}{|c|}{ Dalles Formation (Tdc) } & \multicolumn{2}{|c|}{ Pomona (Tsp) } & \multicolumn{4}{|c|}{ Selah Interbed (Tes) } \\
\hline & & & & $\begin{array}{c}\text { Depth } \\
\text { (m) }\end{array}$ & $\begin{array}{l}\text { Elevation } \\
(\mathrm{m})\end{array}$ & $\begin{array}{l}\text { Thickness } \\
\text { (m) }\end{array}$ & $\begin{array}{l}\text { Depth } \\
\text { (m) }\end{array}$ & $\begin{array}{l}\text { Elevation } \\
(\mathrm{m})\end{array}$ & $\begin{array}{l}\text { Thickness } \\
\text { (m) }\end{array}$ & Depth (m) & $\begin{array}{c}\text { Elevation } \\
\text { (m) }\end{array}$ & $\begin{array}{l}\text { Thickness } \\
\text { (m) }\end{array}$ \\
\hline 2219 & 5055906 & 629950 & 413.0 & 0.0 & 413.0 & 87.8 & - & - & - & - & - & - \\
\hline 2767 & 5057672 & 626153 & 101.5 & - & - & - & 0.0 & 101.5 & 13.6 & 13.6 & 87.9 & 12.3 \\
\hline 2851 & 5058530 & 627336 & 148.4 & 0.0 & 148.4 & 4.3 & 4.3 & 144.1 & 48.7 & 53.4 & 95.4 & 5.5 \\
\hline 3015 & 5057380 & 626911 & 205.7 & 0.0 & 205.7 & 28.4 & 28.4 & 177.3 & 46.3 & - & - & - \\
\hline 3016 & 5056913 & 627051 & 246.3 & 0.0 & 246.3 & 64.0 & 64.0 & 182.3 & 39.6 & - & - & - \\
\hline 51348 & 5056975 & 628184 & 227.7 & 0.0 & 227.7 & 1.2 & 1.2 & 226.5 & 25.3 & - & - & - \\
\hline \multirow[t]{2}{*}{51831} & 5057614 & 629777 & 389.5 & 0.0 & 389.5 & 124.1 & 124.1 & 265.4 & 13.4 & 137.5 & 252.0 & 0.6 \\
\hline & \multicolumn{2}{|c|}{ Lolo (Twpl) } & & \multicolumn{3}{|c|}{ Byron Member Interbed (Teb) } & \multicolumn{2}{|c|}{ Rosalia (Twpr) } & & \multicolumn{3}{|c|}{ Quincy-Squaw Creek Interbed (Teqs) } \\
\hline Continued & Depth & Elevation & Thickness & Depth & Elevation & Thickness & Depth & Elevation & Thickness & Depth & Elevation & Thickness \\
\hline 2219 & 87.8 & 325.2 & 6.7 & 94.5 & 318.5 & 2.4 & 96.9 & 316.1 & 53.4 & 148.7 & 264.3 & 1.6 \\
\hline 2767 & 25.3 & 75.6 & 1.2 & - & - & - & - & - & - & - & & - \\
\hline 2851 & 58.5 & 89.9 & 11.0 & 69.5 & 78.9 & 0.6 & 70.1 & 78.3 & 7.9 & - & - & - \\
\hline 3015 & - & - & - & - & - & - & - & - & - & - & - & - \\
\hline 3016 & - & - & - & - & - & - & - & - & - & - & - & - \\
\hline 51348 & 26.5 & 201.2 & 6.4 & - & - & - & 32.9 & 194.8 & 61.0 & 93.9 & 133.8 & 2.1 \\
\hline \multirow[t]{2}{*}{51831} & - & - & - & - & - & - & 138.1 & 251.4 & 53.0 & 191.1 & 198.4 & 3.1 \\
\hline & \multicolumn{3}{|c|}{$\begin{array}{l}\text { Frenchman Spr. Sentinel Gap } \\
\text { (Twfsg) }\end{array}$} & \multicolumn{3}{|c|}{$\begin{array}{l}\text { Frenchman Spr. Sand Hollow } \\
\text { (Twfsh) }\end{array}$} & & & & & & \\
\hline Continued & Depth & Elevation & Thickness & Depth & Elevation & Thickness & $\begin{array}{l}\text { Completion } \\
\text { Depth }\end{array}$ & $\begin{array}{l}\text { Completion } \\
\text { Elevation }\end{array}$ & Aquifer(s) & & & \\
\hline 2219 & 150.3 & 262.7 & 35.6 & 185.9 & 227.1 & 59.5 & 245.4 & 167.6 & Twfsg/Twfsh & & & \\
\hline 2767 & - & - & - & - & - & - & 27.1 & 74.4 & Twpl & & & \\
\hline 2851 & - & - & - & - & - & - & 78.0 & 70.4 & Tsp/Twpl/Twpr & & & \\
\hline 3015 & - & - & - & - & - & - & 74.7 & 131.0 & Tsp & & & \\
\hline 3016 & - & - & - & - & - & - & 103.6 & 142.7 & Tsp & & & \\
\hline 51348 & 96.0 & 131.7 & 33.5 & 129.5 & 98.2 & 29.0 & 158.5 & 69.2 & Twfsg/Twfsh & & & \\
\hline 51831 & - & - & - & 194.2 & 195.3 & 75.5 & 269.7 & 119.8 & Twfsh & & & \\
\hline
\end{tabular}


Table 2: Well log interpretations for wells with no XRF control, but were selected for water sampling.

\begin{tabular}{|c|c|c|c|c|c|c|c|c|c|c|c|c|}
\hline \multirow[b]{2}{*}{$\begin{array}{l}\text { State Well } \\
\text { Number }\end{array}$} & \multirow[b]{2}{*}{$\begin{array}{c}\text { UTM } \\
\text { Northing } \\
(\mathrm{m})\end{array}$} & \multirow[b]{2}{*}{$\begin{array}{l}\text { UTM } \\
\text { Easting } \\
(\mathrm{m})\end{array}$} & \multirow[b]{2}{*}{$\begin{array}{l}\text { Elevation } \\
\quad(\mathrm{m})\end{array}$} & \multicolumn{3}{|c|}{ Dalles Formation (Tdc) } & \multicolumn{2}{|c|}{ Pomona (Tsp) } & \multirow[b]{2}{*}{ Thickness (m) } & \multicolumn{3}{|c|}{ Selah Interbed (Tes) } \\
\hline & & & & $\begin{array}{l}\text { Depth } \\
\text { (m) }\end{array}$ & $\begin{array}{l}\text { Elevation } \\
\quad(\mathrm{m})\end{array}$ & $\begin{array}{l}\text { Thickness } \\
\text { (m) }\end{array}$ & $\begin{array}{l}\text { Depth } \\
\text { (m) }\end{array}$ & $\begin{array}{l}\text { Elevation } \\
\quad(\mathrm{m})\end{array}$ & & $\begin{array}{l}\text { Depth } \\
\text { (m) }\end{array}$ & $\begin{array}{l}\text { Elevation } \\
\text { (m) }\end{array}$ & $\begin{array}{l}\text { Thickness } \\
\text { (m) }\end{array}$ \\
\hline 2759 & 5059239 & 626229 & 118.3 & 0.0 & 118.3 & 51.5 & 51.5 & 66.8 & 57.3 & 108.8 & 9.5 & 39.6 \\
\hline 2765 & 5058883 & 625846 & 83.2 & 0.0 & 83.2 & 3.0 & 3.0 & 80.2 & 55.8 & 58.8 & 24.4 & 22.3 \\
\hline 3019 & 5056535 & 628021 & 252.1 & 0.0 & 252.1 & 12.2 & 12.2 & 239.9 & 30.5 & - & - & - \\
\hline 50012 & 5059164 & 626000 & 94.5 & 0.0 & 94.5 & 31.7 & 31.7 & 62.8 & 59.7 & 91.4 & 3.1 & 19.9 \\
\hline 50250 & 5057694 & 626133 & 100.9 & - & - & - & 0 & 100.9 & 16.2 & 16.2 & 84.7 & 9.4 \\
\hline 50811 & 5056408 & 626505 & 128.0 & - & - & - & - & - & - & - & - & - \\
\hline 51025 & 5056461 & 628241 & 283.2 & 0.0 & 283.2 & 26.5 & 26.52 & 256.6 & 4.6 & 31.1 & 252.1 & 8.5 \\
\hline 51497 & 5059270 & 625758 & 81.4 & 0.0 & 81.4 & 28.3 & 28.3 & 53.1 & 50.9 & 79.2 & 2.2 & 40.6 \\
\hline \multirow[t]{2}{*}{51778} & 5058946 & 625921 & 80.8 & 0.0 & 80.8 & 4.9 & 4.9 & 75.9 & 31.7 & - & - & - \\
\hline & \multicolumn{3}{|l|}{ Lolo (Twpl) } & \multicolumn{3}{|c|}{ Byron Member Interbed (Teb) } & \multicolumn{3}{|c|}{ Rosalia (Twpr) } & \multicolumn{3}{|c|}{$\begin{array}{l}\text { Quincy-Squaw Creek Interbed } \\
\text { (Teqs) }\end{array}$} \\
\hline Continued & Depth & Elevation & Thickness & Depth & Elevation & Thickness & Depth & Elevation & Thickness & Depth & Elevation & Thickness \\
\hline 2759 & 148.4 & -30.1 & 11.3 & - & - & - & 159.7 & -41.4 & 8.8 & - & - & - \\
\hline 2765 & 81.1 & 2.1 & 18.6 & - & - & - & 99.7 & -16.5 & 23.4 & - & - & - \\
\hline 3019 & 42.7 & 209.4 & 2.4 & - & - & - & 45.1 & 207.0 & 10.7 & - & - & - \\
\hline 50012 & 111.3 & -16.8 & 11.2 & - & - & - & 122.5 & -28.0 & - & 160.3 & -65.8 & 9.2 \\
\hline 50250 & 25.6 & 75.3 & 10.1 & - & - & - & 35.7 & 65.2 & 50.6 & - & - & - \\
\hline 50811 & 0.0 & 128.0 & 9.8 & - & - & - & 9.8 & 118.2 & 49.3 & - & - & - \\
\hline 51025 & 39.6 & 243.6 & 29.0 & - & - & - & 68.6 & 214.6 & 41.7 & - & - & - \\
\hline 51497 & 119.8 & -38.4 & 11.3 & - & - & - & 131.1 & -49.7 & 20.7 & - & - & - \\
\hline \multirow[t]{2}{*}{51778} & \multirow{2}{*}{\multicolumn{3}{|c|}{$\begin{array}{l}\text { Frenchman Spr. Sentinel Gap } \\
\text { (Twfsg) }\end{array}$}} & & - & - & - & - & - & - & - & - \\
\hline & & & & \multicolumn{6}{|c|}{$\begin{array}{l}\text { Frenchman Spr. Sand Hollow } \\
\text { (Twfsh) }\end{array}$} & & & \\
\hline Continued & Depth & Elevation & Thickness & Depth & Elevation & Thickness & $\begin{array}{l}\text { Completion } \\
\text { Depth }\end{array}$ & $\begin{array}{l}\text { Completion } \\
\text { Elevation }\end{array}$ & Aquifer(s) & & & \\
\hline 2759 & - & - & - & - & - & - & 168.5 & -50.2 & Twpl/Twpr & & & \\
\hline 2765 & - & - & - & - & - & - & 123.1 & -39.9 & Twpl/Twpr & & & \\
\hline 3019 & - & - & - & - & - & - & 55.8 & 196.3 & Twpr & & & \\
\hline 50012 & 169.5 & -75.0 & 12.2 & - & - & - & 181.7 & -87.2 & Twfsg & & & \\
\hline 50250 & 86.3 & 14.6 & 12.2 & - & - & - & 98.5 & 2.4 & Twfsg & & & \\
\hline 50811 & 59.1 & 68.9 & 21.4 & 80.5 & 47.5 & 1.8 & 82.3 & 45.7 & Twpr/Twfsg/Twfsh & & & \\
\hline 51025 & - & - & - & - & - & - & 110.3 & 172.9 & Twpl/Twpr & & & \\
\hline 51497 & - & - & - & - & - & - & 151.8 & -70.4 & Twpl/Twpr & & & \\
\hline 51778 & - & - & - & - & - & - & 36.6 & 44.2 & Tsp & & & \\
\hline
\end{tabular}




\section{Surface Geologic Mapping Results}

As previously mentioned, detailed geologic mapping was focused along streambeds to locate where CRB interflow zones outcrop within the lower reaches of Mosier Creek and to a lesser extent, Dry and Rowena Creeks. In some locations, such as Rowena Creek, known stratigraphic information was sufficient to ascertain the flows without XRF analysis. In Mosier and Dry Creeks, hand samples were analyzed for XRF data to aid in differentiating flows.

\section{Hand Sample XRF Results Along Streams}

Seven hand samples were analyzed to identify CRB flows along Mosier Creek and Dry Creek (Figure 35). The analysis was sufficient to differentiate between flows using a $\mathrm{TiO}_{2}$ vs. Cr variation diagram, identifying flows of Pomona (Tsp), Priest Rapids Lolo (Twpl), and Priest Rapids Rosalia (Twpr). Hand sample locations are provided in Figure 36 for sites with and without XRF data. 


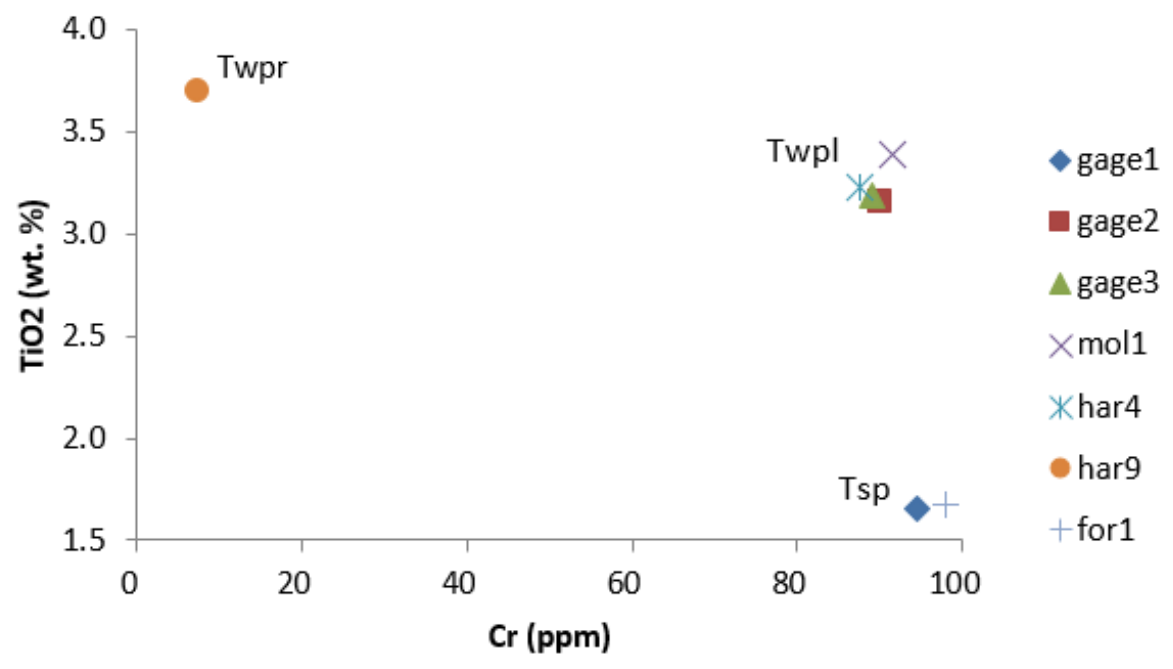

Figure 35: $\mathrm{TiO}_{2}$ vs $\mathrm{Cr}$ variation diagram displaying the hand sample $\mathrm{XRF}$ analysis results from the Mosier area along Mosier Creek and Dry Creek. Tsp: Pomona, Twpl: Lolo, Twpr: Rosalia.

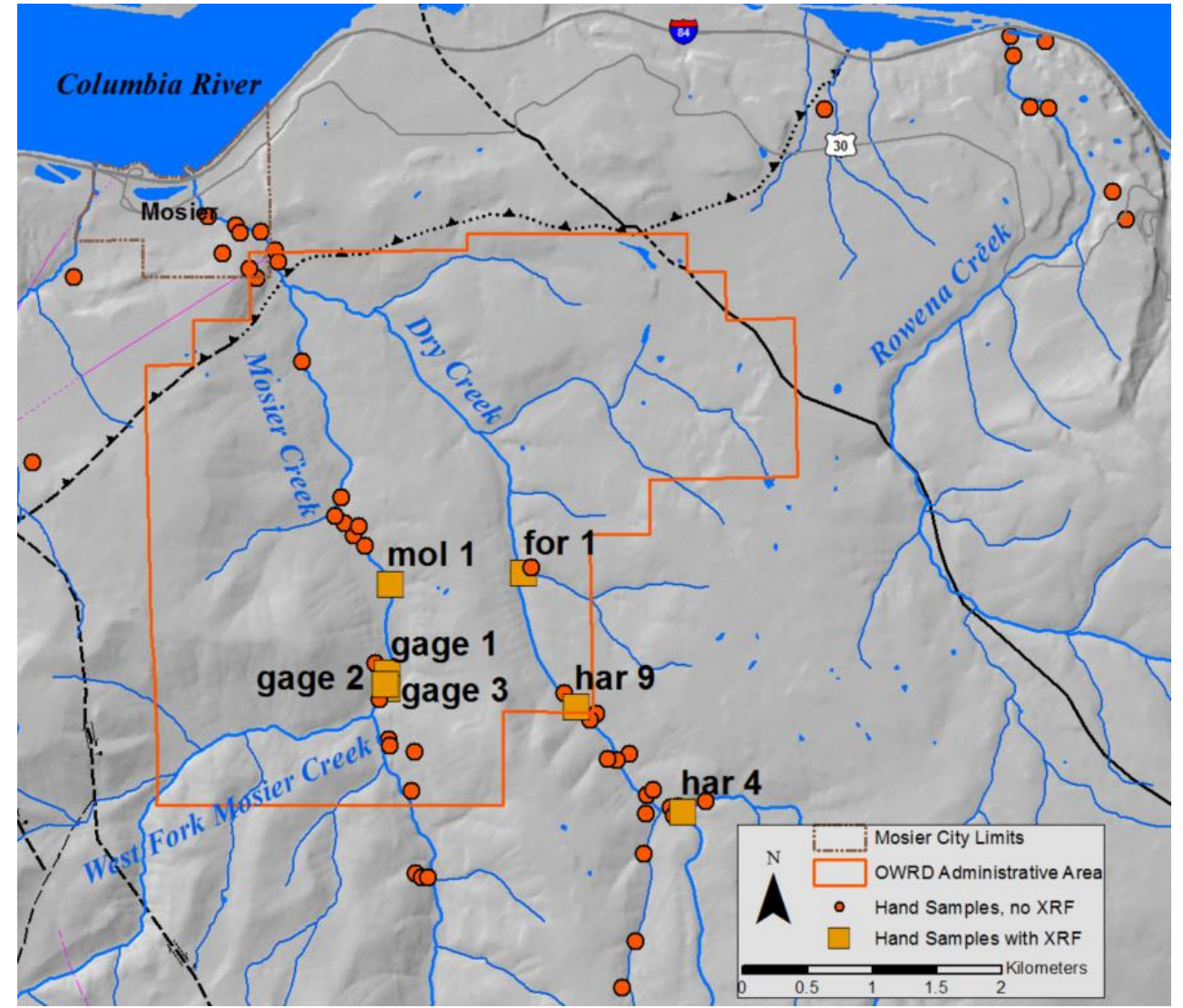

Figure 36: Location map of all hand samples collected in the Mosier area, both with and without XRF data, along Mosier, Dry, and Rowena Creeks. 


\section{Mosier Creek}

Four samples were collected for XRF analysis along Mosier Creek. Samples, Gage 1, 2, and 3, were collected in close proximity to an existing USGS stream gage in Mosier Creek, just below the confluence with West Fork Mosier Creek. Gage 1 confirmed the outcrop above the road to be the Pomona flow, shown in Figure 16. Gage 2, gage 3, and mol 1 were all proven to be Lolo, as shown in Figure 35. The outcrop where mol 1 was sampled is shown below, displaying a weathered and vesicular appearance, interpreted as the Lolo flow top.

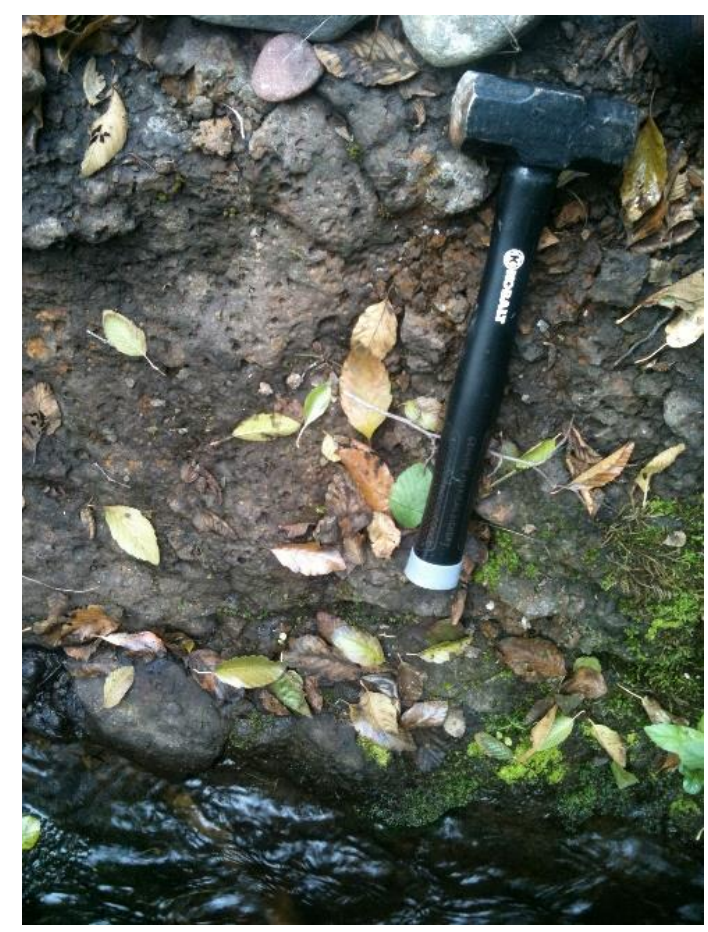

Figure 37: Outcrop where mol 1 was collected, representing the Lolo flow top with abundant vesicles exposed in Mosier Creek.

Six samples were collected $0.35 \mathrm{~km}$ downstream from sample $\mathrm{mol} 1$; these were all interpreted as the Pomona Member because of hackly entablature and 
predictable stratigraphic position above the Lolo flow. This hackly entablature is commonly seen in the middle to upper portions of the flow (Figure 38).

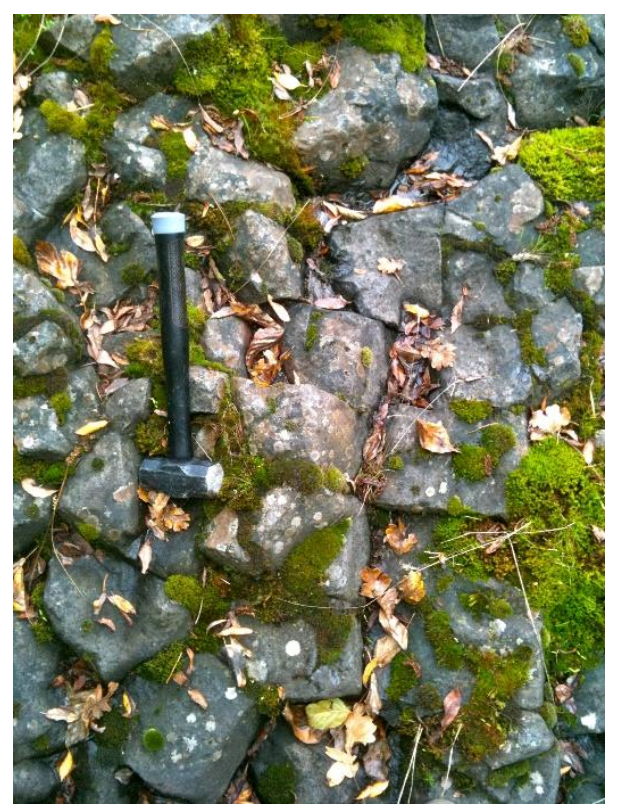

Figure 38: Pomona outcrop along Mosier Creek, displaying the commonly seen thin, hackly entablature of middle and upper portions of this flow.

\section{Dry Creek}

Three samples were sent in for XRF analysis along Dry Creek, for 1, har 9, and har 4. Starting the furthest upstream, har 4, identified the Lolo flow in the upper portions of Dry Creek. This outcrop has a thin, platy appearance and is highly fractured (Figure 40). The platy appearance is also seen in Mosier Creek just above a more massive columnar base representing sample gage 2, shown in Figure 20.

Underlying the Lolo flow in Dry Creek is Rosalia, identified by the sample har 9, where Dry Creek has incised through the Pomona and Lolo flows exposing the top of the Rosalia. This outcrop contains a similar thin, platy appearance above a more massive columnar portion (Figure 41). A spring was located approximately 30 
meters upstream from sample har 9, interpreted to be issuing from Lolo's base near the lower contact with Rosalia. The last sample along Dry Creek, for 1, served to identify the Pomona basalt.

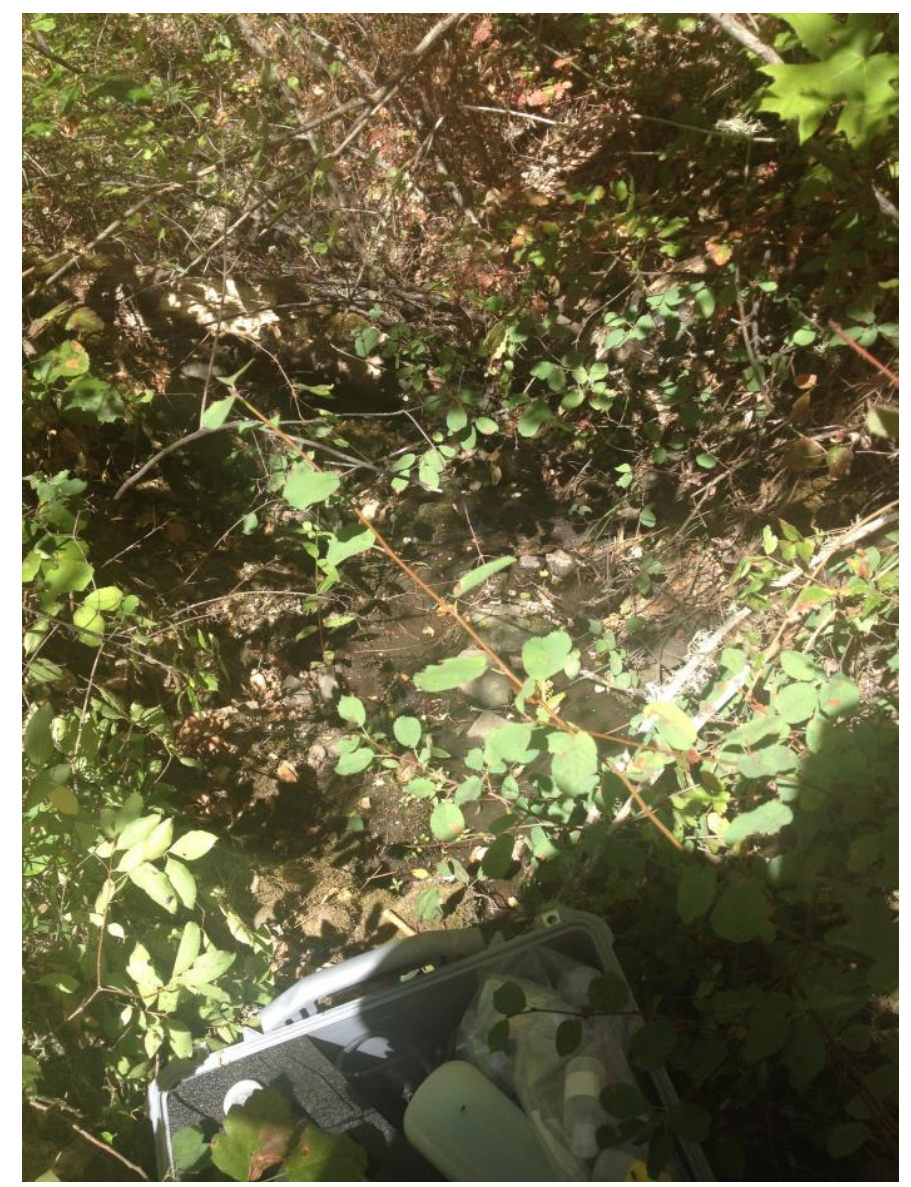

Figure 39: Small spring issuing from the Lolo and Rosalia contact along Dry Creek. 


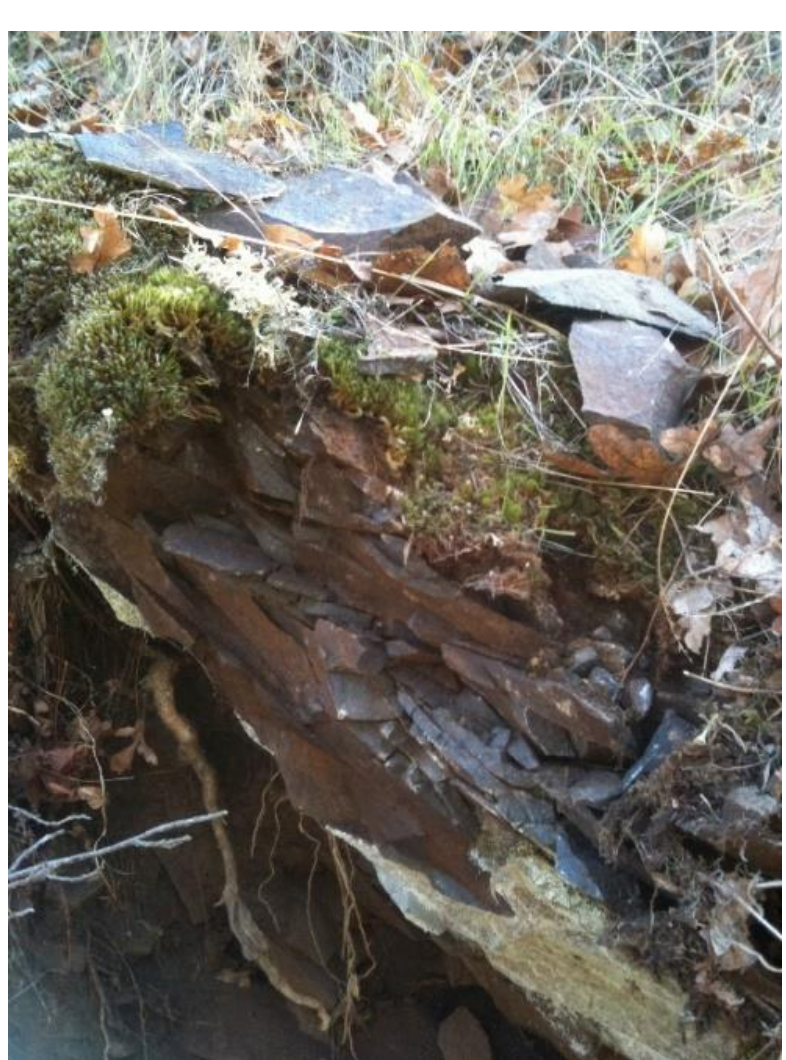

Figure 40: Thin, platy, and highly fractured outcrop of the Lolo flow in Dry Creek where sample har 4 was collected.

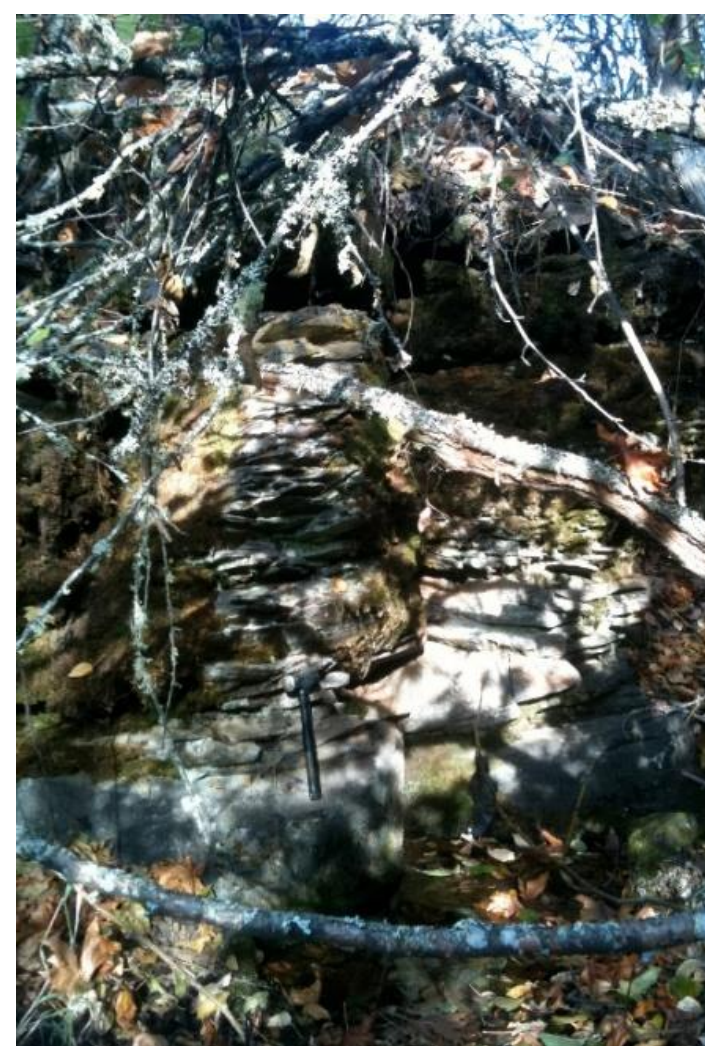

Figure 41: Outcrop of Rosalia within Dry Creek displaying a thin, platy, and fractured appearance overlying massive columns (sample har 9).

\section{Rowena Creek}

Existing geologic data within Rowena Dell has provided a relatively well-

understood stratigraphy due to the presence of the Roza marker bed. Thus, mapping along this ephemeral stream was focused on locating existing springs during summer base flow conditions. One spring was located within the streambed in late September 2011 (Figure 42). The spring was issuing out of the upper Frenchman Springs flow of Sentinel Gap. This determination was based on it being located stratigraphically below the Roza flow, which outcrops prominently within Rowena 
Dell. Figure 24 displays a highly vesicular flow top of the Sentinel Gap located roughly 3 meters upstream from the spring location.

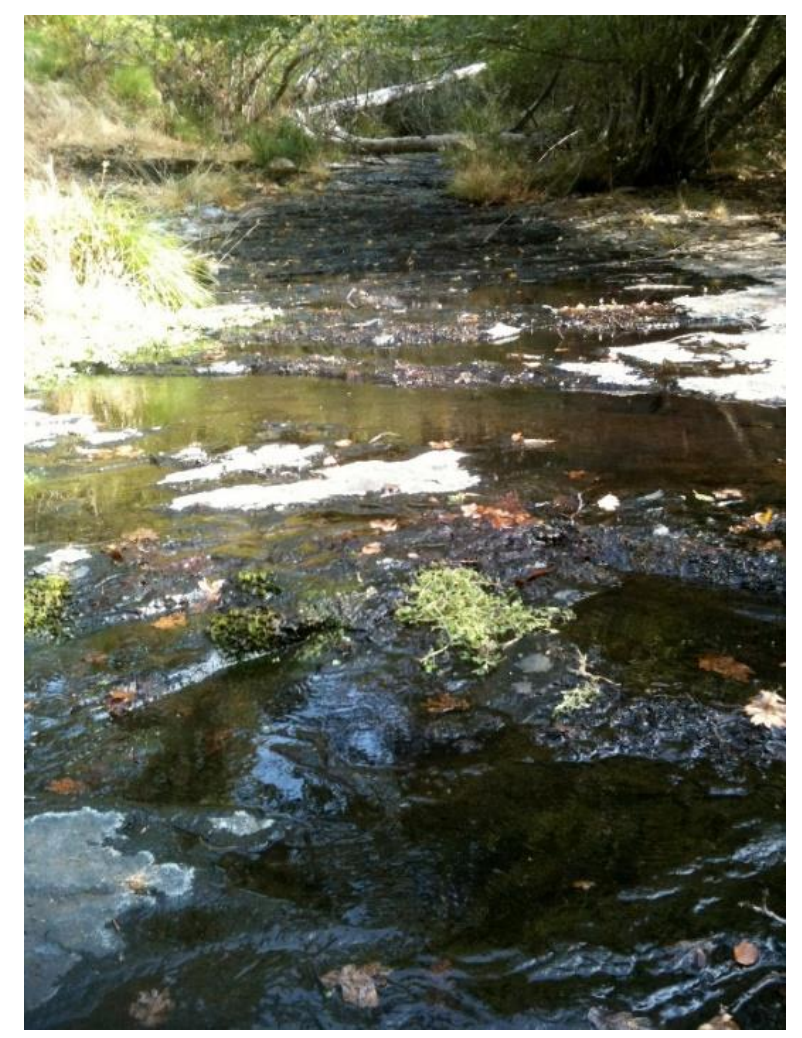

Figure 42: Spring within Rowena Creek during late September, 2011, issuing from the upper Frenchman Springs flow.

\section{Geologic Maps: Mosier, Dry, and Rowena Creeks}

Two separate geologic maps are provided to better display the key geologic mapping results along each creek.

Figure 43 displays a large- scale map deliberately cutting off the lower

portions of Mosier Creek to display the important geologic contacts of Pomona, Lolo, and Rosalia flows, along this reach of Mosier Creek. Figure 44 displays the eastern portion of the study area with the results for Rowena Creek. 


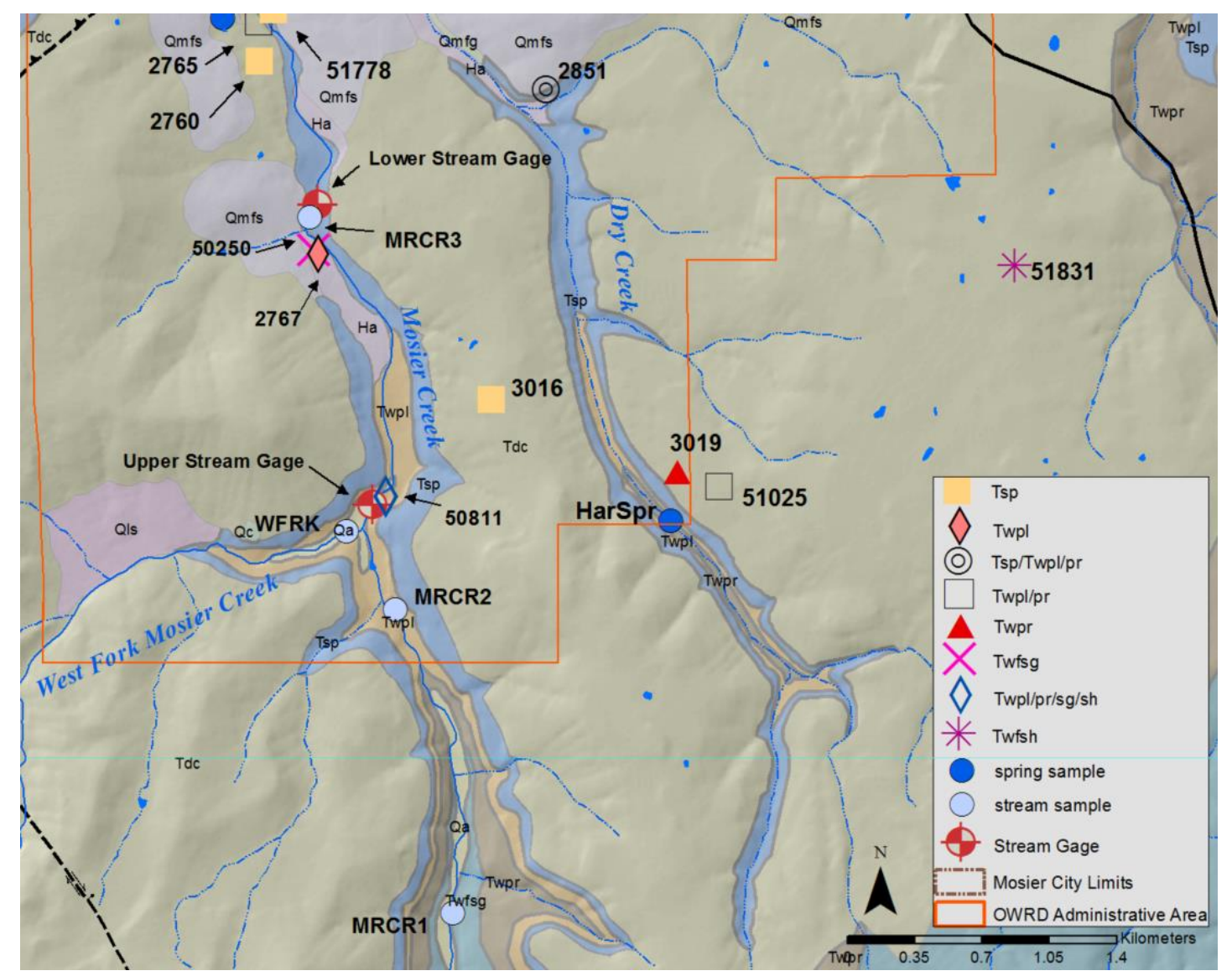

Figure 43: Detailed geologic mapping results for Columbia River Basalt flow outcrops within the upper portions of Mosier Creek and Dry Creek (modified from a compilation of Newcomb (1969), Lite and Grondin (1988), McClaughry et al. (2012), and Lite (2013). The lower reaches of Mosier Creek are shown in the next figure. Ha: alluvium (Holocene), Qmfs/Qmfsg: Missoula flood deposits, Qa: alluvium (Quaternary), Qls: Landslide deposit, Tdc: Dalles Gr. Chenoweth Form., Tsp: Pomona, Twpl: Lolo, Twpr: Rosalia, Twfsg: Sentinel Gap, Twfsh: Sand Hollow. 


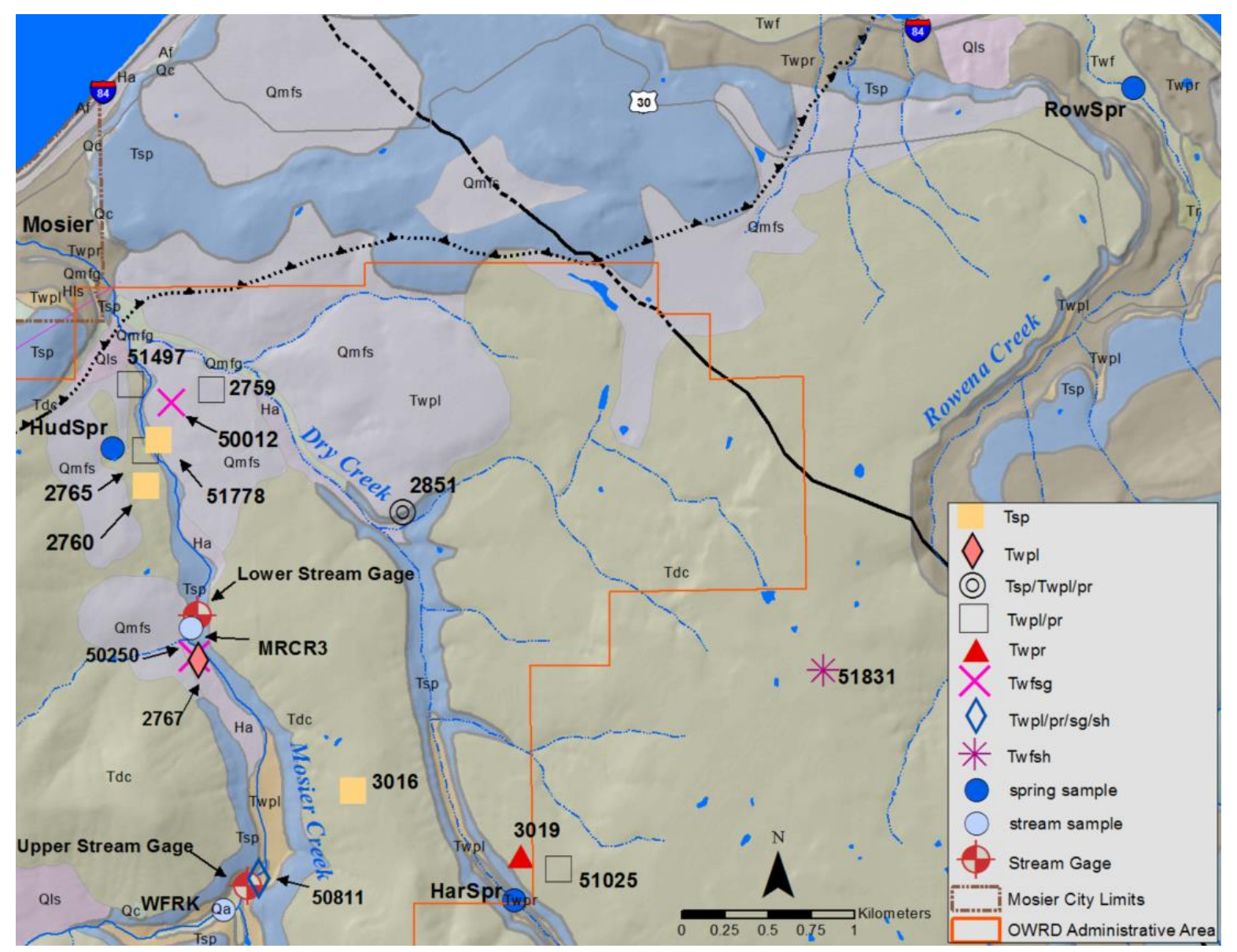

Figure 44: Detailed geologic mapping results and spring location displaying lower Mosier Creek and the eastern portion of the study area with Rowena Creek (modified from a compilation of Newcomb (1969), Lite and Grondin (1988), and Burns et al. (2012). Refer to Figure 11 for label descriptions. Ha: alluvium (Holocene), Qmfs/Qmfsg: Missoula flood deposits, Qa: alluvium (Quaternary), Qls: Landslide deposit, Tdc: Dalles Gr. Chenoweth Form., Tsp: Pomona, Twpl: Lolo, Twpr: Rosalia, Twfsg: Sentinel Gap, Twfsh: Sand Hollow. 


\section{Discussion}

\section{Subsurface Geology}

The major objective of geologic mapping was to identify aquifer-containing CRB flows, both within surface water drainages and at depth in wells. The XRF analysis results and well log interpretations serve to enhance the understanding of subsurface stratigraphy in the Mosier area. For the purpose of this discussion, the wells in Table 1 Table 2 are discussed based on their geographic location: lower, middle, and upper reaches of Mosier and Dry Creeks.

The lower reach wells include the following: WASC 2759, 2765, 50012, 51497, and 51778. All of these wells are, or were, flowing artesian wells, meaning that the water is under pressure and flows to or above the land surface. This is due to the water pressure that builds behind the Rocky Prairie thrust fault as the waters in the permeable CRB interflow zones encounter the area of low-permeability created by the fault.

The drill cuttings samples from WASC 51497 that were analyzed and reported in Lite (2013) help define the basalt units in the area. Lite reported this well was open to both Lolo and Rosalia water-bearing zones. Analysis of additional well logs in the lower reach revealed that one well is completed in the Pomona flow (51778), two others were determined to interconnect the Lolo and Rosalia (2759 and 2765), while the deepest well is completed in the Sentinel Gap flow (50012). 
The middle area consists of five wells: 2767, 2851, 3016, 50250, and 50811. WASC 50250 and 2767 are within 30 meters of each other with the former tapping into the Sentinel Gap, while the latter is completed in the Lolo aquifer. Both of these wells are in close proximity to the mapped exposures of the Lolo and Pomona interflow zones in Mosier Creek, providing excellent groundwater elevation data to contrast against the surface water - groundwater interaction location.

Through XRF analysis, WASC 2851 and 3016 provided stratigraphic depth control for Dry Creek and the saddle between Mosier and Dry Creeks. Analysis of the well $\log$ for WASC 3016 reveals it is completed into the Pomona aquifer. WASC 50811, due to its shallow seal and casing depth, is open to the units of Lolo, Rosalia, Sentinel Gap, and Sand Hollow.

The wells in the upper reaches of the study area and east of Dry Creek are: $2219,3019,51025,51348$, and 51831. Except for the two wells at lower elevations closer to Dry Creek, WASC 3019 and 51025, most of the wells at high elevation penetrated into the deeper Frenchman Springs aquifers. WASC 3019 appears to be completed in the singular aquifer of Rosalia, while WASC 51025 indicates an open interval for the Lolo and Rosalia aquifers.

WASC 51831 is completed into the Sand Hollow and provides the easternmost stratigraphic control, with XRF analysis from eight depths within the well. Interestingly, the flows of Lolo and Sentinel Gap do not appear to be encountered in the well. It is not likely that these flows were overlooked in sampling, especially 
because the Sentinel Gap is thought to have flow thicknesses of 34 meters in the nearest well involved in this study, albeit that well is $1.7 \mathrm{~km}$ away. Additionally, Ken Lite reports that a continuous downhole video of this well indicates that Lolo and Sentinel Gap are not present (personal communication with Ken Lite, Oregon Water Resources Department, July 6, 2016). One explanation could be that both Lolo and Sentinel Gap pinch out before this location on the flank of the Columbia Hills anticline.

Analysis of well logs and well-cutting XRF data has increased the amount of subsurface data and overall understanding of subsurface geology in the Mosier area. Most important to this study was the identification of wells suitable for water sampling purposes, based on the aquifers a well encounters and a detailed understanding of each well's construction. This aspect will be discussed further in the following chapters.

\section{Surface Geology}

The identification of aquifer-containing CRB flows within streambeds was focused primarily on determining the elevation of those contacts to be referenced against groundwater elevations in Mosier area wells. It is important to consider the inherent elevation and location uncertainties. Elevation data of contacts identified within streambeds were based off the 10 meter DEM analyzed in ArcGIS' ArcMap. The vertical uncertainty in this dataset is $2.44 \mathrm{~m}$. The horizontal uncertainty for the quadrangle is $0.05 \mathrm{~cm}$ on the map, meaning 12.2 meters on the $1: 24,000$ scale. 
Additional uncertainty is incorporated into any elevation and location data due to the handheld GPS measurement; at best this uncertainty is \pm 3 meters.

Within Mosier Creek the important flows of Lolo and Pomona were located, signifying a key reach of Mosier Creek for possible groundwater - surface water interaction. The XRF sample, $\mathrm{mol} \mathrm{1}$, is at an elevation of $107.8 \mathrm{~m}$ according to the $10 \mathrm{~m}$ DEM dataset. At this location within the stream, taking into account the north/northwest dip toward the axis of the Mosier syncline, is the top of the Lolo aquifer where interaction between stream and groundwater would likely occur.

The Pomona interflow zone is at the base of the Pomona flow, overlying the Lolo flow. Thus, this location and elevation was confirmed to be just downstream of the Lolo contact. The elevation of potential interaction between the creek and the water-bearing portion of the Pomona flow is approximately $100-107$ meters. Notably, the Selah interbed is not present on the surface in this location. $500 \mathrm{~m}$ downstream from the Lolo exposure in Mosier Creek, in wells 2767 and 50250, the Selah interbed is present with an estimated thickness of 9-12 m. The Selah interbed is known to thin out further away from the Mosier syncline (Lite, 2013) but this also indicates that the Selah has likely been scoured out by the stream. Furthermore, this indicates that there may not be as much of a low flow boundary between the Lolo and Pomona flows at this location due the absence of the Selah interbed. This reach where the Lolo and Pomona aquifers outcrop in Mosier Creek is the primary focus of groundwater - surface water interaction for this study. 


\section{Chapter 3- Physical and Chemical Hydrogeology}

\section{Introduction}

Several methods were used to investigate the control that surface water groundwater interactions have on groundwater levels in the lower Mosier Creek drainage. In this study, the primary methods of investigation were: 1) groundwater level data collection in specific wells; 2) stream flow measurements along a key reach of Mosier Creek; and 3) sample collection from area wells, streams, and springs, and subsequent chemical analysis.

The primary objectives of water sampling and hydrochemical analysis were to determine if geochemical evidence supports results regarding the interaction between Mosier Creek and CRB aquifers and if discrete CRB aquifers can be differentiated based on their hydrochemical signatures.

Geologic mapping was completed from 2011 to 2012, and all water samples (wells, streams, and springs) for geochemical data were collected from May to October 2012. The groundwater-level data were compiled over the period of record. The stream discharge data are from gaging sites established by the USGS and OWRD and covers the period from 2012 until December 2015.

\section{Background}

There have been many groundwater studies carried out on Columbia River Basalt Group (CRBG) aquifers because of declining water levels and concerns about the sustainability of the resource (Lite and LaMarche, 2014; Lite, 2013; Burns et al., 2012; Carey, 2011; Porcello et al., 2009; Vlassopoulos et al., 2009, and Larson, 
2000). While these studies have been successful in delineating groundwater in CRB aquifers, most studies are conducted over a more regional scale and attempt only to differentiate CRB aquifers by Formation, rather than by Member. For example, many eastern and central Washington studies have successfully differentiated waters from Grand Ronde Formation aquifers from Wanapum or Saddle Mountains Formations (Porcello et al., 2009 and Vlassopoulos, 2009). However, they typically have not attempted to delineate between waters from Priest Rapids Member flows or Frenchman Springs Member flows within the Wanapum Formation.

This study attempts to delineate ground waters from aquifers within individual flows over one watershed of approximately $90 \mathrm{~km}^{2}$. This task is complicated by CRB flows having similar geochemical compositions, only varying by small parts per million shifts in elemental concentrations, as indicated by the XRF data presented above. Lite and Grondin (1988) provided geochemical data for this same area but further investigation is required, especially due to the hypothesized change in interaction and additional aquifer delineation information provided in Lite (2013). Background information is discussed below to explore techniques previously used to identify and distinguish discrete CRBG aquifers and their recharge sources.

\section{Stable Isotopes}

In some regions of central and eastern Washington, age dating techniques have revealed groundwater in lower CBRG aquifers to be thousands of years old with little appreciable recharge since the Ice Age (Crosby and Chatters, 1965; 
Newcomb, 1972). Age dating techniques using ${ }^{14} \mathrm{C}$ and tritium are beyond the scope of this project; furthermore, the upper aquifers in the Mosier area are thought to receive modern recharge (Lite and Grondin, 1988). However, the stable isotopes of $\delta^{18} \mathrm{O}$ and $\delta^{2} \mathrm{H}$ are used in this study to assist in the delineation of waters from discrete CRB aquifer units and to help assess groundwater recharge elevations.

The stable isotopes of hydrogen are ${ }^{1} \mathrm{H}$ and ${ }^{2} \mathrm{H}$ and the most abundant isotopes of oxygen are ${ }^{16} 0$ and ${ }^{18} 0$. The utility of oxygen and hydrogen isotopes results from their fractionation as they move through the hydrologic cycle. During precipitation and any phase change, water vapor becomes progressively depleted in the heavier isotopes relative to the liquid water (Faure, 1986). The global meteoric water line (GMWL) was developed by Craig (1961) and is given by the equation: $\delta^{2} H$ $=8 \delta^{18} \mathrm{O}+10$. Values of $\delta^{18} \mathrm{O}$ and $\delta^{2} \mathrm{H}$ will deviate from the GMWL, depending on latitude, distance inland from the ocean, temperature, and elevation. For this reason, typically studies utilizing stable isotopes will attempt to develop a local meteoric water line (LMWL). This is particularly useful in determining groundwater - surface water interaction determinations and identifying evaporative effects. The development of a LMWL was not feasible for this project. The closest precipitation isotope data for this region is from the central Cascades and as far north as Mt. Hood. These studies are discussed later in this chapter as they relate to stable isotope data collected for this study. 


\section{Geochemical Signatures}

In the absence of extensive isotopic data, studies must rely on geochemical signatures imparted upon the groundwaters as a result of water-rock interactions that take place along its flow path. One such study was conducted by Vlassopoulos et al. (2009), in which they examined the hydrochemical evolution of groundwaters in CRBG aquifers of central Washington in the Columbia Basin Ground Water Management Area (GWMA). Geochemical modeling and other exploratory data analysis methods (hierarchical cluster analysis and principle component analysis) were used to develop proxies for groundwater age that can be used to identify and distinguish between CRBG aquifers and their source waters.

Vlassopoulos et al. (2009) explained that three major processes influence the evolution of groundwater in CRBG aquifers: "(1) evaporation and reaction with surface sediments, (2) dissolution of basalt by carbonic acid, and (3) silicate hydrolysis." They indicated that initially waters are less evolved Ca-Mg- $\mathrm{HCO}_{3}$ type waters and then with longer resident times waters evolve to $\mathrm{Na}-\mathrm{HCO}_{3}$ type water. The lower Grande Ronde Basalt aquifers of central Washington contain the most evolved waters resulting in $\mathrm{Na}-\mathrm{Cl}$ dominated water, which often contains elevated fluoride concentrations. Through a geochemical investigation, Vlassopoulos et al. were able to develop a cation ratio proxy versus Carbon-14 (pmc) (Figure 45). 


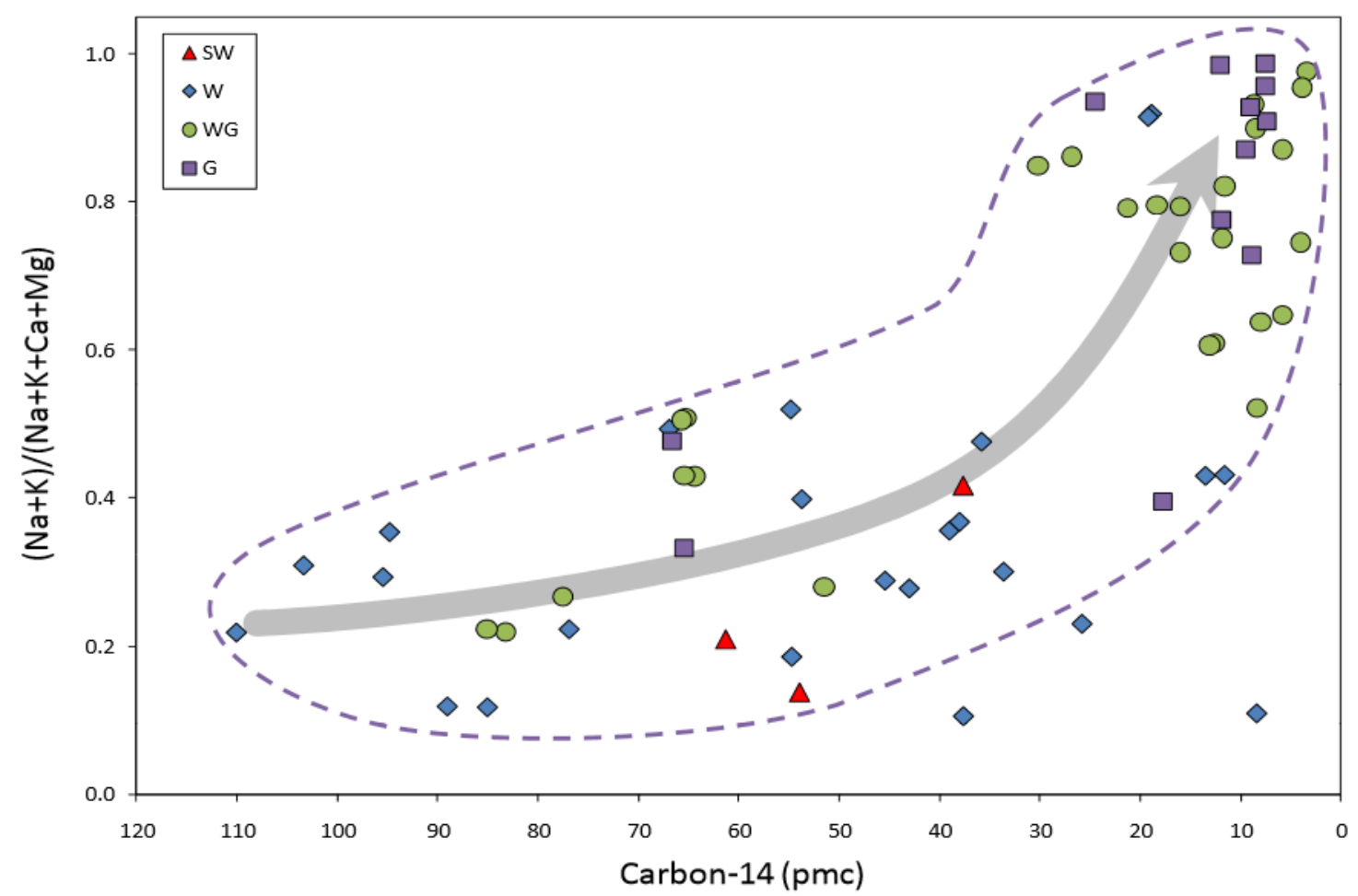

Figure 45: Cation ratio $(\mathrm{Na}+\mathrm{K}) /(\mathrm{Na}+\mathrm{K}+\mathrm{Ca}+\mathrm{Mg})$ versus Carbon-14 activity (percent modern) from CRBG groundwater samples from central Washington (Vlassopoulos et al., 2009). SW: wells producing from Saddle Mountains and Wanapum Basalts, W: Wells from Wanapum Basalts, WG: wells producing from Wanapum and Grand Ronde Basalt, and G: wells producing only from Grande Ronde Basalt.

\section{Methods}

\section{Groundwater-Level Data}

Groundwater-level data were compiled for seven area wells from the OWRD water level database. The data range varied for each well with data for some wells going back to the mid-1970s. The decline in groundwater-level over this period of record has been well documented (Newcomb, 1969, Lite and Grondin, 1988, Burns et al., 2012, and Lite, 2013, Lite and LaMarche, 2014). The individual hydrographs for this study display a date range from the year 2000 to December 2015. In this time frame, specifically in 2004, Lite (2013) and Lite and LaMarche (2014) noticed a 
change of slope in area hydrographs (Figure 4); this change in slope and the subsequent groundwater-level fluctuations are the primary focus of this study. OWRD groundwater-level data are generally available with quarterly measurements: March, June or July, September or October, and a final measurement in December or January. Most important to this study is the drawdown in wells in the orchard tract area during the summer months through fall, before recharge from increased precipitation, similar to the analysis of Lite and LaMarche (2014).

Of the seven wells selected for groundwater-level observation, four are irrigation wells (2758, 2759, 50012, and 50250), and three are domestic wells $(2760,2767$, and 50811). Wells were chosen based on knowledge of the geologic framework in the Mosier area, and especially from close consultation with Ken Lite of the OWRD, and a review of each well's construction details to determine seal and casing depths (Table 3). 
Table 3: Well construction summary for wells with available hydrochemistry and/or groundwater level data.

\begin{tabular}{lccccl}
$\begin{array}{c}\text { State } \\
\text { Well \# }\end{array}$ & $\begin{array}{c}\text { Surface } \\
\text { Elev. } \\
(\mathbf{m})\end{array}$ & $\begin{array}{c}\text { Total Depth } \\
\mathbf{( m )}\end{array}$ & $\begin{array}{c}\text { Seal Depth } \\
\mathbf{( m )}\end{array}$ & $\begin{array}{c}\text { Casing } \\
\text { Depth (m) }\end{array}$ & \multicolumn{1}{c}{ Open Units } \\
\hline 3016 & 246.3 & 103.6 & 6.0 & 103.6 & Tsp \\
51778 & 80.8 & 36.6 & 18.3 & 18.3 & Tsp \\
2767 & 101.5 & 27.1 & 23.7 & 23.7 & Twpl \\
3019 & 252.1 & 55.8 & 15.8 & 15.8 & Twpr *(Tdc, Tsp, Twpl) \\
50012 & 94.5 & 181.7 & 170.7 & 170.7 & Twfsg \\
50250 & 100.9 & 98.5 & 83.2 & 83.2 & Twfsg \\
51831 & 389.5 & 269.7 & 201.1 & 201.1 & Twfsh ${ }^{+}$ \\
2759 & 118.3 & 168.5 & 130.7 & 133.5 & Twpl, Twpr \\
2765 & 83.2 & 123.1 & 17.3 & 83.2 & Twpl, Twpr \\
51497 & 81.4 & 151.8 & 86.8 & 150.8 & Twpl, Twpr \\
51025 & 283.2 & 110.3 & 18 & 19 & Twpl, Twpr *(Tdc, Tsp) \\
50811 & 128.0 & 82.3 & 5.8 & 5.8 & Twpl, Twpr, Twfsg, \\
& & & & & \\
Hydrograph & & & & & \\
\hline 2760 & 113.1 & 103.6 & 25.9 & 79.2 & Tsp \\
2758 & 114.9 & 150.9 & 102.1 & 102.1 & Twpl, Twpr \\
\hline
\end{tabular}

* Well is also open to the units in parentheses through annular space and/or the well is open to those units but they were not water-bearing according to the well report.

+ Well construction only permitted water sampling from a cistern.

Unit Abbreviations: Tdc: Dalles Form., Tsp: Pomona, Twpl: Lolo, Twpr: Rosalia, Twfsg: Sentinel Gap, Twfsh: Sand Hollow

Similar to the errors and uncertainties discussed above concerning geologic mapping locations and elevations, the groundwater elevation data contains uncertainties as well. Uncertainties could typically exist from measurement or instrument error. These uncertainties are not thought to exceed $+/-0.15 \mathrm{~m}$. Uncertainties also occur because OWRD elevation data for the well is typically taken from the USGS 7.5-minute quadrangle. As described previously, the vertical uncertainty is approximately 6 meters.

\section{Stream Discharge Data}

Stream discharge data were compiled along a key stream reach to characterize the interaction between Mosier Creek and CRB interflow zones. An 
existing Mosier Creek continuous stream gage (USGS Station \#14113200) is located approximately thirty meters below the confluence with West Fork Mosier Creek. In order to measure interaction, another stream gage was necessary. A lower stream gage was installed by the OWRD downstream of a likely discharge point for Lolo and Pomona interflow zones (Station \# 14113210) (see Figure 4 and Figure 5). The lower streamflow gage was located so gains/losses could be attributed to the Lolo and Pomona interflow zones.

Stream discharge measurements were collected continuously by the Oregon Water Resources Department (OWRD), along this key stretch of Mosier Creek since installation of the lower stream gage on April 17, 2012. An analysis of the preliminary gain/loss data between the gages are discussed in Lite and LaMarche (2014). This study, using the stream discharge measurements at both gages are analyzed in the same methodology of Lite and LaMarche (2014). Data were most important in the summer to early fall moths during base flow and/or low flow conditions for Mosier Creek, which coincides with drawdown from local irrigation; therefore, data are displayed from March through December for each year. The location of both stream gages, upper and lower, are provided in Figure 46. 


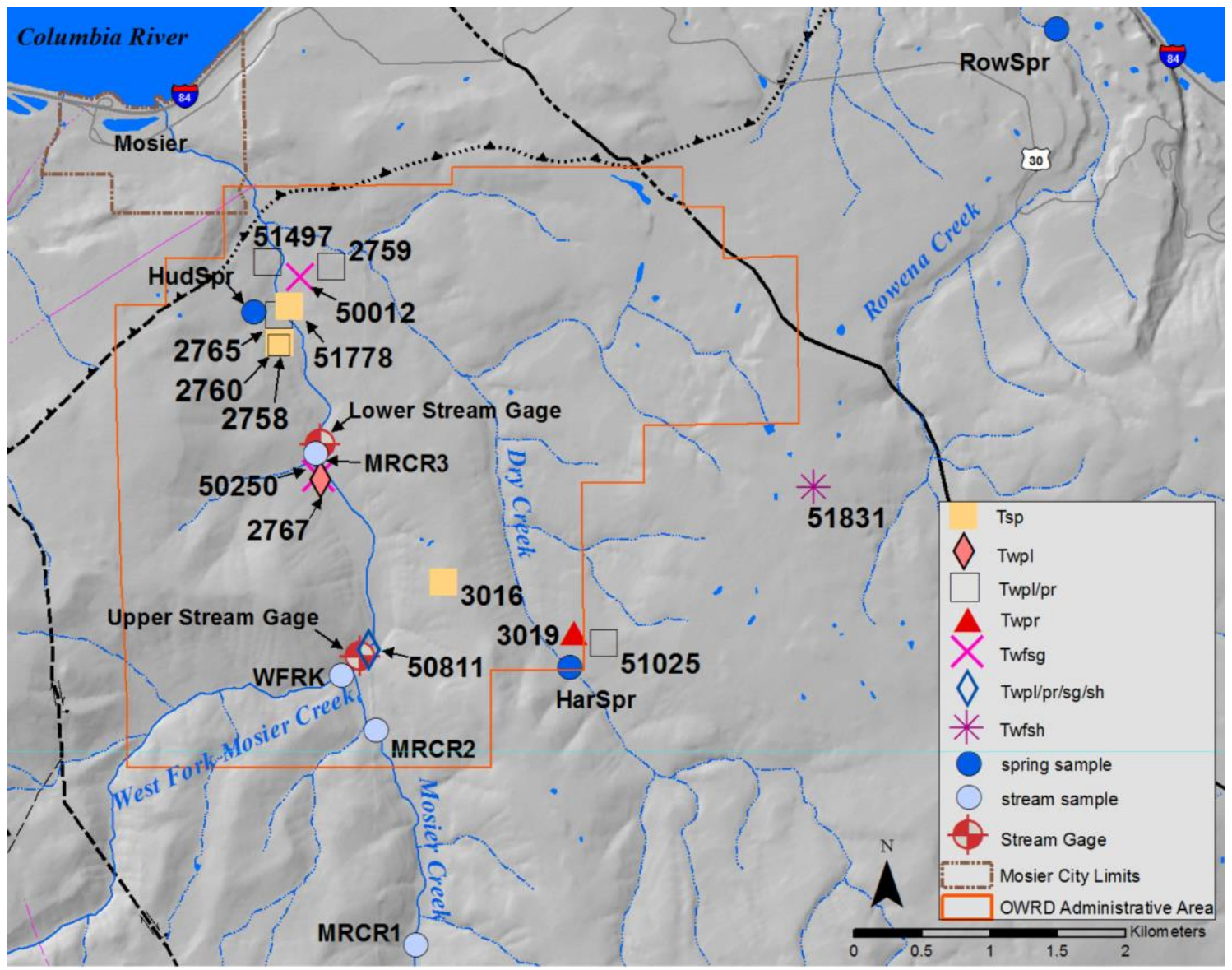

Figure 46: Location map for all water sampling: wells, streams, springs. The location of the upper and lower stream gages is also shown. Refer to Figure 11 for a complete unit description. Tsp: Pomona, Twpl: Lolo, Twpr: Rosalia, Twfsg: Sentinel Gap, Twfsh: Sand Hollow.

\section{Spring and Surface-Water Sampling}

Four stream locations and three springs were chosen for sampling to attain hydrochemical data. Stream site selections were chosen in an attempt to ascertain any hydrochemical differences imparted upon the water by different aquifers and/or flows. The location of sample MRCR1 was upstream of the mapped contact of the Frenchman Springs and Rosalia flows. The MRCR2 location was roughly 350 meters downstream of the Rosalia/Lolo contact. The WFRK site was selected to 
identify any hydrochemical differences between waters of the West Fork Mosier Creek and the waters of Mosier Creek. The stream sample MRCR3 is located in the same area as the lower stream gage, approximately $745 \mathrm{~m}$ downstream of the Lolo and Pomona contact in Mosier Creek.

Three springs were sampled as part of this study to investigate the chemical signature with regard to the aquifer from which the springs issue. HudSpr is issuing from the Dalles Formation. HarSpr was discovered during geologic mapping and is thought to be issuing from the base of the Lolo aquifer, near the Lolo/Rosalia contact in Dry Creek. HarSpr exhibited only minimal flow and appeared to be stagnant, especially during the first sampling campaign. In the eastern side of the study area, a small spring (RowSpr) was sampled issuing from the upper Frenchman Springs flow of Sentinel Gap in the Rowena Creek bed where the stream went from dry to flowing.

Each sample was filtered on site with a dedicated 0.45 -micron filter. Samples were collected using $60 \mathrm{ml}$ or $125 \mathrm{ml}$ low-density polyethylene (LDPE) bottles after having been soaked prior to use in 5\% nitric acid solution and rinsed with 18 megohm-cm (nanopure) water. Cation samples were acidified using $2 \%$ by volume nitric acid. Anion and isotope sample bottles were overfilled to minimize air space. All samples were immediately placed in an ice chest after collection and transferred to a refrigerator upon return from the field. One field blank and one field duplicate were collected for each sampling campaign. 
Field measurements were collected using a YSI Professional Plus multiparameter meter with appropriate probes. Measurements included temperature $\left({ }^{\circ} \mathrm{C}\right) \mathrm{pH}$, specific conductivity $(\mu \mathrm{S} / \mathrm{cm})$, oxidation-reduction potential (ORP; $\mathrm{mV}$ ), and dissolved oxygen (D.O., \%). The YSI meter was calibrated in the field at the beginning of each day, and as needed throughout the day, as per the manufacturer's recommendations using fresh commercial $\mathrm{pH}$ buffers, conductivity standards and freshly prepared Zobel solution. Total alkalinity was also measured in the field at each site using a Hach digital titrator, with either 0.16 or $1.60 \mathrm{~N}$ sulfuric acid $\left(\mathrm{H}_{2} \mathrm{SO}_{4}\right)$ and bromocresol green indicator.

\section{Well Sampling}

Well sampling was conducted to attain a sample from each major aquifer. Table 3 provides the well construction summary and the open intervals of each well sampled. Seven of the sampled wells were completed in only one aquifer. Five wells were sampled that are open to and possibly interconnect multiple aquifers, four that are open to the Lolo and Rosalia aquifers, and one deep well that interconnects all major aquifers except for the Pomona.

Wells were purged prior to sampling to remove any stagnant, nonrepresentative water from the well casing. Although it is generally recommended to purge three well volumes prior to sampling, this was generally not possible due to time constraints and the great depth of some irrigation wells; therefore, the wells were purged until meter readings of $\mathrm{pH}$, specific conductivity, and temperature were stable over three meter readings spaced five minutes apart. Residential wells 
were sampled before passing through any filtration or water softening units. The construction of WASC 51831 only allowed for water sampling from a cistern, as there was no upstream sampling port on the well. The large volume of the cistern made flushing the entire volume impractical. Field parameters were measured and recorded in the field in the same manner as described above for streams and springs except that measurements were made using a flow-through cell to minimize aeration of and gas loss from groundwater samples.

\section{Cation, Anion, and Silica Analysis}

For each water sample, major ion analysis was conducted in the Trace Element Analytical Laboratory at Portland State University. Major cations were analyzed with an Agilent Technologies 700 Series Inductively Coupled Plasma Optical Emission Spectrometer (ICP-OES). Major anions were analyzed with the use of a Dionex Model 2500 ion chromatograph. Silica analysis was completed with a Beckman Coulter DU 730 untraviolet spectrophotometer (UV-Vis) with the molybdate yellow method. Three to eight external standards from certified commercial stock standards were used to calibrate instruments prior to each sample batch. Laboratory blanks, replicates, and verification standards were run for quality control purposes.

\section{Isotope Analysis}

Stable isotope analysis of oxygen and hydrogen was conducted through the Colorado Plateau Isotope Laboratory (CPIL) at Northern Arizona University on a Thermo Finnigan Delta ${ }^{\text {PLUS }}$ XL IRMS using a Gas Bench II gas preparation and 
introduction system. Precision for analytical procedures is $\pm 0.1 \%$ for oxygen and $\pm 1.0 \%$ for deuterium. Isotope values are reported in standard $\delta$-notation as per mil (\%o) deviations from the Vienna Standard Mean Ocean Water (VSMOW) reference standard.

\section{Results}

The results of this physical hydrogeology are presented first, followed by the chemical hydrogeology. A more detailed discussion relating physical and chemical hydrogeology is provided in the discussion and conclusion sections.

\section{Physical Hydrogeology Results}

\section{Ground water-Level Data}

As discussed in the methods section, the groundwater decline over the period of record has been well documented in previous studies (Lite and Grondin, 1988; Burns et al., 2012; Lite, 2013; and Lite and LaMarche, 2014). The groundwater-level decline in the Mosier area over the period of record is reflected in the well hydrographs presented in Figure 47; the hydrographs also reveal a change in the decline trend in 2004. From 2004 to 2013, the hydrographs of Wasco county wells $2758,2759,50012,50250$, and 50811 , show some decline, though much less than before 2004. Figure 48 displays the linear regression equation for the periods of $1974-2003$ and $2004-2015$. The slope of the decline trend until 2003 was -0.0032 , while after 2004 it was -0.0012 . WASC 50012, although not plotted, provides a similar difference in decline trends, -0.0054 and -0.001 for pre and post-2004 data. A steeper decline is noted for the period from 2014 to 2016. 
The groundwater levels in each well either reached or dipped below 90 meters (amsl) for the first time in the record on 2015. The steep decline in groundwater elevations prior to 2004 are far less pronounced or absent for several of the wells shown in Figure 47. Lite (2013) indicates that the close proximity of these wells (WASC 2760 and 2767) to their aquifer discharge points in Mosier Creek has likely allowed the groundwater level to remain relatively stable.

WASCO 2760, a well completed in the Pomona aquifer and located in lower Mosier Creek, fluctuated annually from 91 to 94 meters (amsl) from 2005 to 2010. During drawdown conditions in 2010 through 2014 the trend has less annual variation with groundwater levels hovering just above and below $91 \mathrm{~m}$ (amsl). Summer 2014 and 2015 data indicates the groundwater level dips to around $90 \mathrm{~m}$ (amsl).

WASC 2767 is completed in the Lolo aquifer along Mosier Creek. There were no data points available for this well from 1987 to 2011 but within that time frame there was only a decline from $101 \mathrm{~m}$ to $98.6 \mathrm{~m}$ (amsl). The data from 2011 to 2014 indicates the groundwater level at its lowest was just above $97 \mathrm{~m}$ (amsl), and in 2015 there is increased drawdown to below $97 \mathrm{~m}$. 


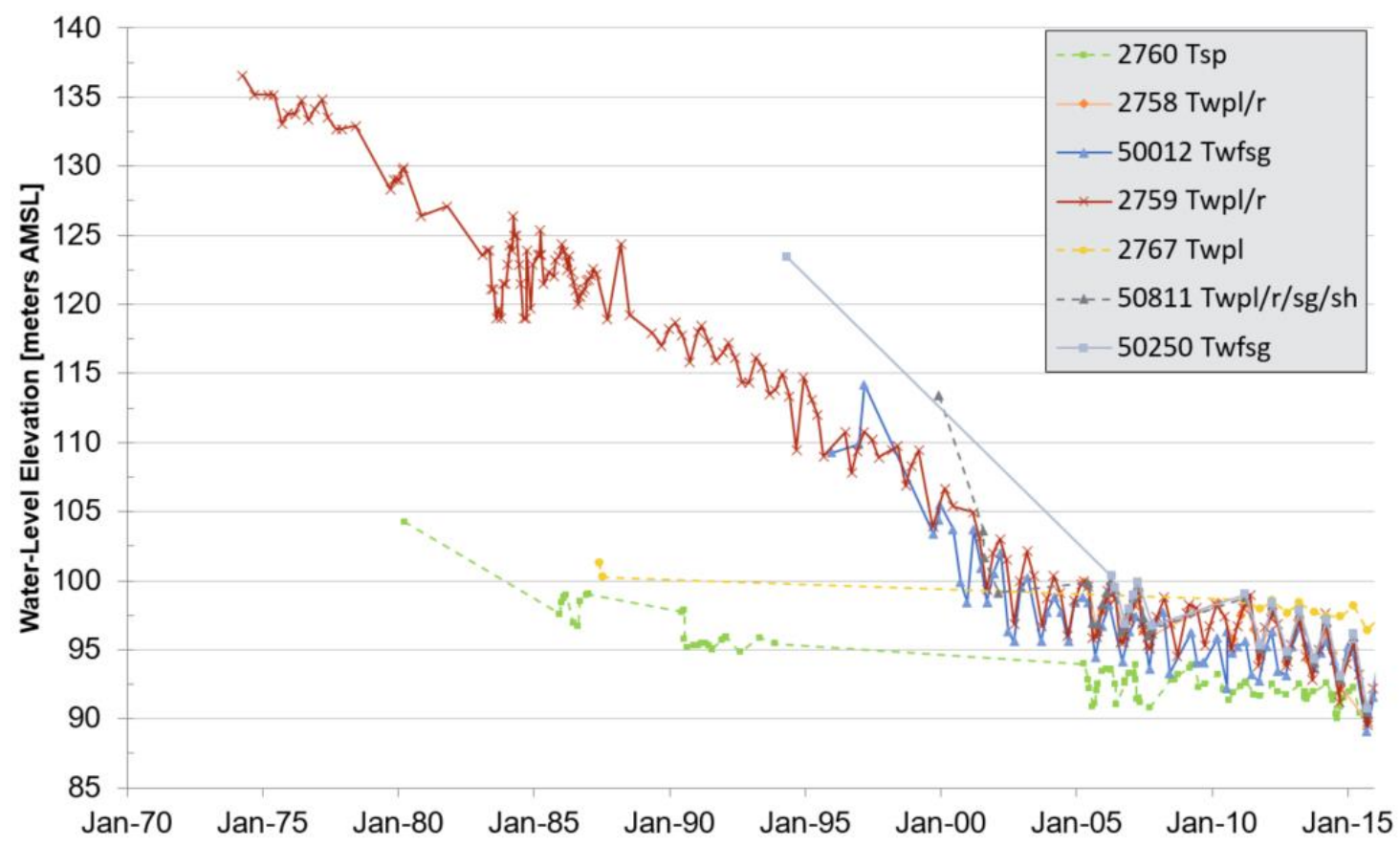

Figure 47: Hydrographs for seven wells within the OWRD Administrative Area, displaying the substantial groundwater-level decline over the period of record, as well as an apparent common equilibrium elevation for area wells occurring in 2004 (Lite, 2013). Domestic wells are displayed with dashed lines and irrigation wells have solid lines. The interflow zone(s) of each well are displayed in the legend. Refer to Table 3 for well construction details. Tsp: Pomona, Twpl: Lolo, Twpr: Rosalia, Twfsg: Sentinel Gap, Twfsh: Sand Hollow.

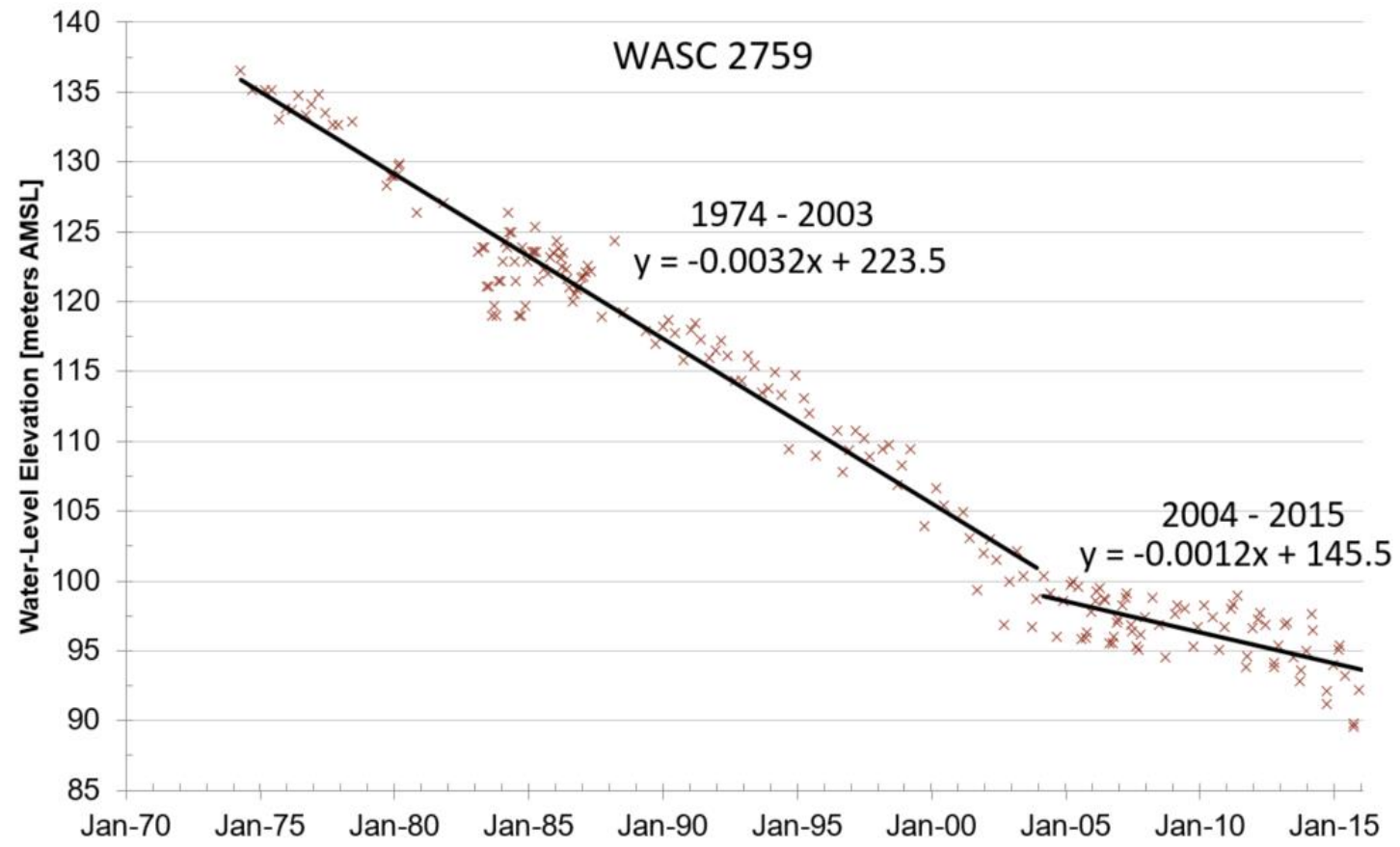

Figure 48: Groundwater level decline trends for WASC 2759 split between 1974 - 2003 and $2004-2015$. 


\section{Stream Discharge Data}

Continuous stream discharge data are available for both upper and lower stream gages via the OWRD and USGS surface water database websites. Location of each gaging site is provided in Figure 46. Mosier Creek stream discharge increases in winter with increased precipitation and decreases in the summer. Data are displayed for each year since lower gage installation in April 2012. If the discharge increases from the upper to lower gage then the stream is deemed to have gained flow from the groundwater system; if it decreases, then it is assumed that surface water is lost to the groundwater system.

Figure 49 displays the gains/losses for 2012. Mosier Creek was a losing stream at the time of installation when stream discharge was over $0.20 \mathrm{~m}^{3} / \mathrm{s}$. By mid-May the stream discharge decreases to below $0.20 \mathrm{~m}^{3} / \mathrm{s}$ and the stream remains predominantly a slightly gaining stream until mid-July. The stream becomes a slightly losing stream in mid-July and remains losing until October 7, 2012. The stream briefly transitions to a losing stream again but primarily is a gaining stream from mid-October through the rest of the year. At most, Mosier Creek was losing $0.013 \mathrm{~m}^{3} / \mathrm{s}$ of water to the groundwater system from August 2124,2012 , amounting to approximately $35-40 \%$ of base flow.

During 2013, Mosier Creek transitions from a gaining to a losing stream on June $8^{\text {th }}$ and remains a losing stream until late September. At most the stream was losing $0.019 \mathrm{~m}^{3} / \mathrm{s}$ to the groundwater system from July 10 - 15, 2013 (Figure 50). This amounted to approximately $40-43 \%$ of base flow. 
During base flow conditions in 2014, Mosier Creek had a brief period in late June where it was a losing stream only to transition back to gaining stream in early July. The stream did not transition to a predominantly losing stream across this reach until July 23 and continued to lose water to the groundwater system until mid-October (Figure 51). During this time the maximum loss was $0.011 \mathrm{~m}^{3} / \mathrm{s}$, approximately $16-26 \%$ of base flow.

The data for 2015 indicates less streamflow in Mosier Creek when compared to previously discussed years. With the exception of a period between mid-January through mid-February, when stream discharge is very high, the creek is losing beginning in March and continuing through the summer. There also appears to be less base flow in summer 2015. The stream discharge is consistently below 0.028 $\mathrm{m}^{3} / \mathrm{s}$ from July through September 2015 .

\section{Uncertainty}

Stream discharge data was downloaded from either the OWRD or USGS streamflow data websites. Additional streamflow measurements in the field were not carried out for this study. For this reason, a full discussion regarding errors and uncertainty is beyond the scope of this project. However, an estimate of uncertainty is provided for the data from the upper USGS gage. The water data reports for 2013 and 2014 indicate an uncertainty of "poor," meaning the data are not estimated to meet the requirement that $95 \%$ of daily discharge values are within $15 \%$ of the true value. Despite the poor rating of uncertainty for the upper gage, the findings are likely significant because they are consistent with those of Lite and LaMarche 
(2014) and because there is a consistency in the cyclic nature to the data where losses are observed each year during the low flow period. 


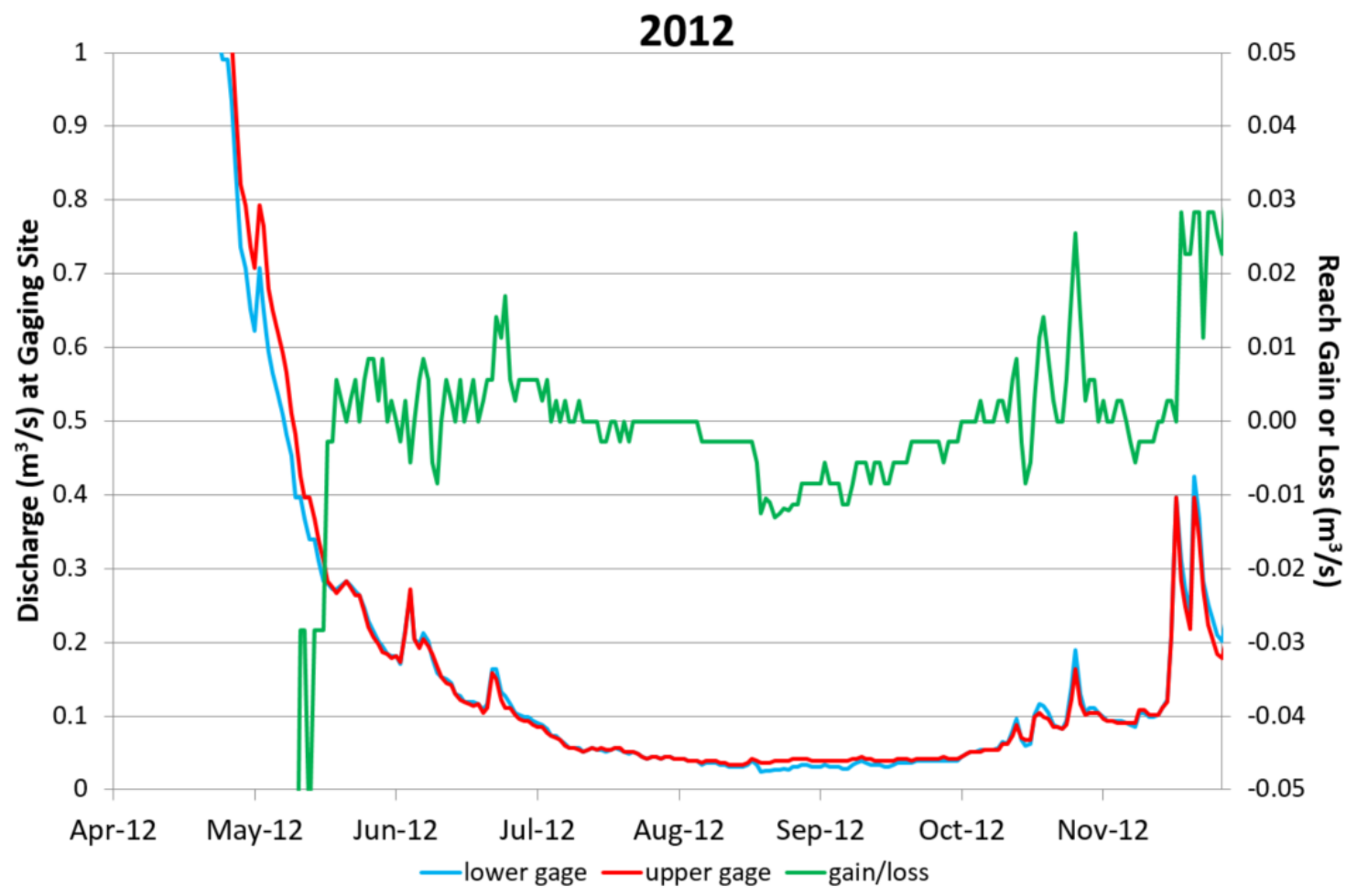

Figure 49: Steam discharge data and gains/losses across the Lolo/Pomona aquifers in Mosier Creek from April 2012 through December 2012.

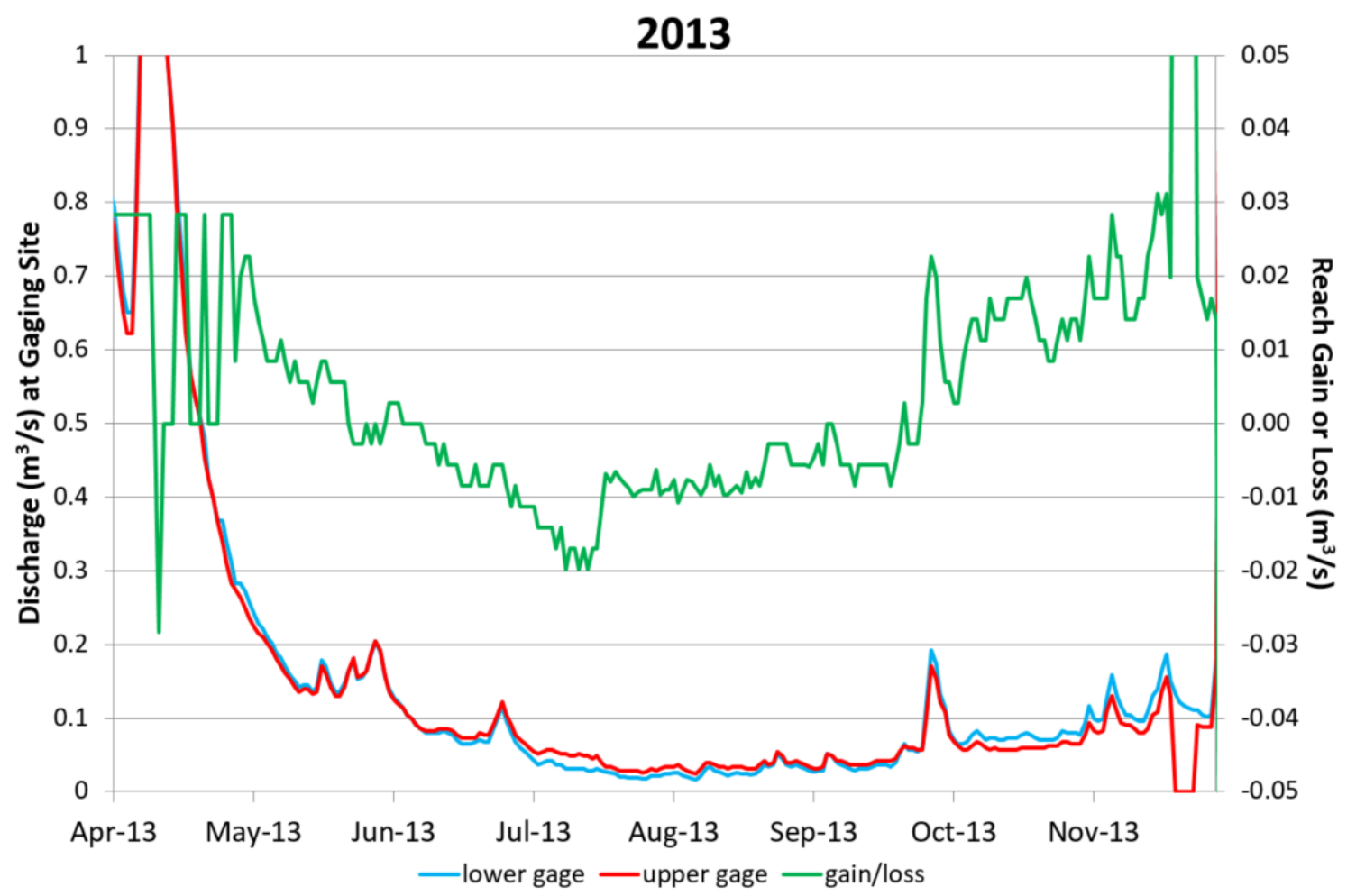

Figure 50: Steam discharge data and gains/losses across the Lolo/Pomona aquifers in Mosier Creek from March 2013 through December 2013. 


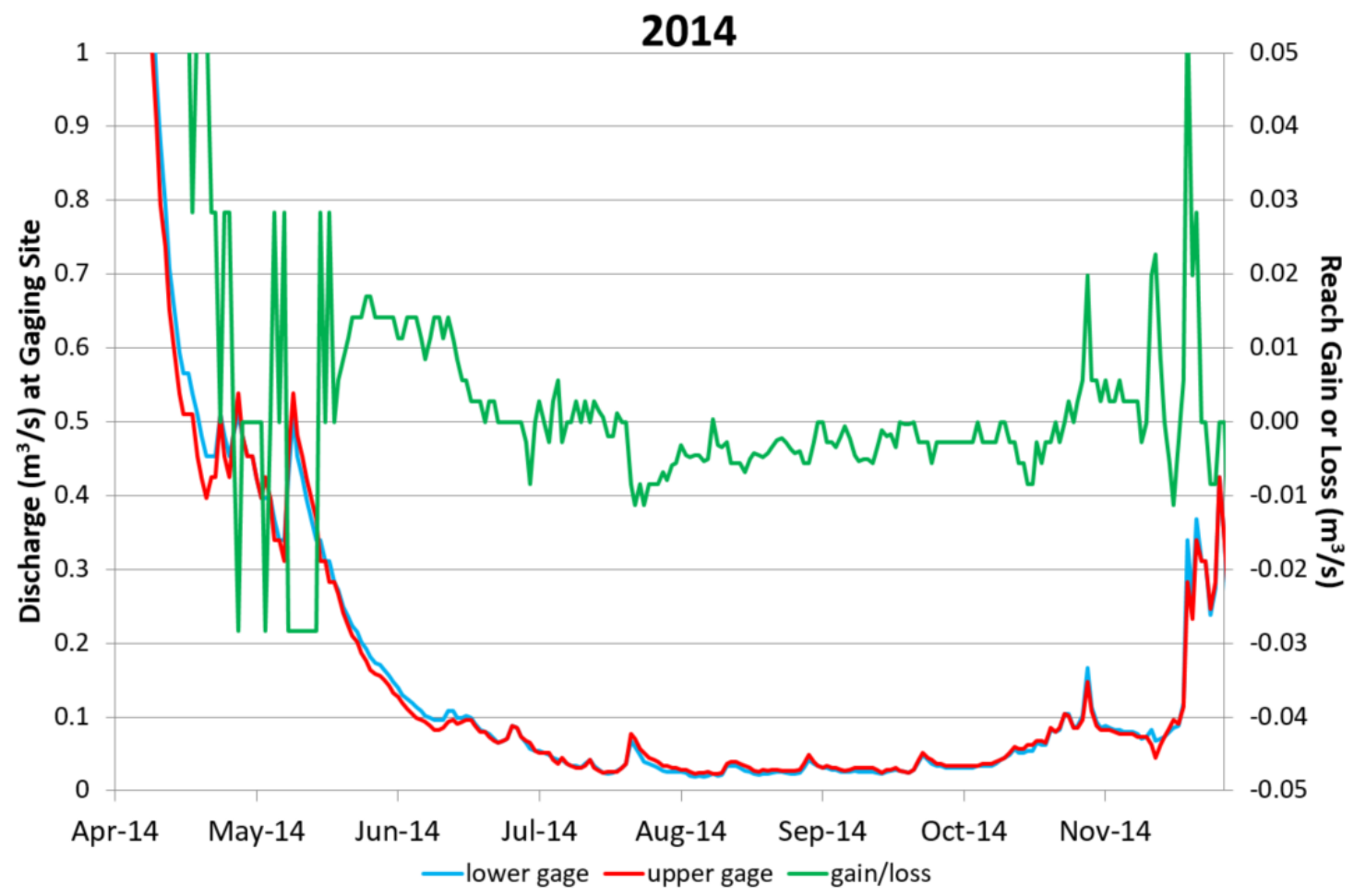

Figure 51: Steam discharge data and gains/losses across the Lolo/Pomona aquifers in Mosier Creek from March 2014 through December 2014.

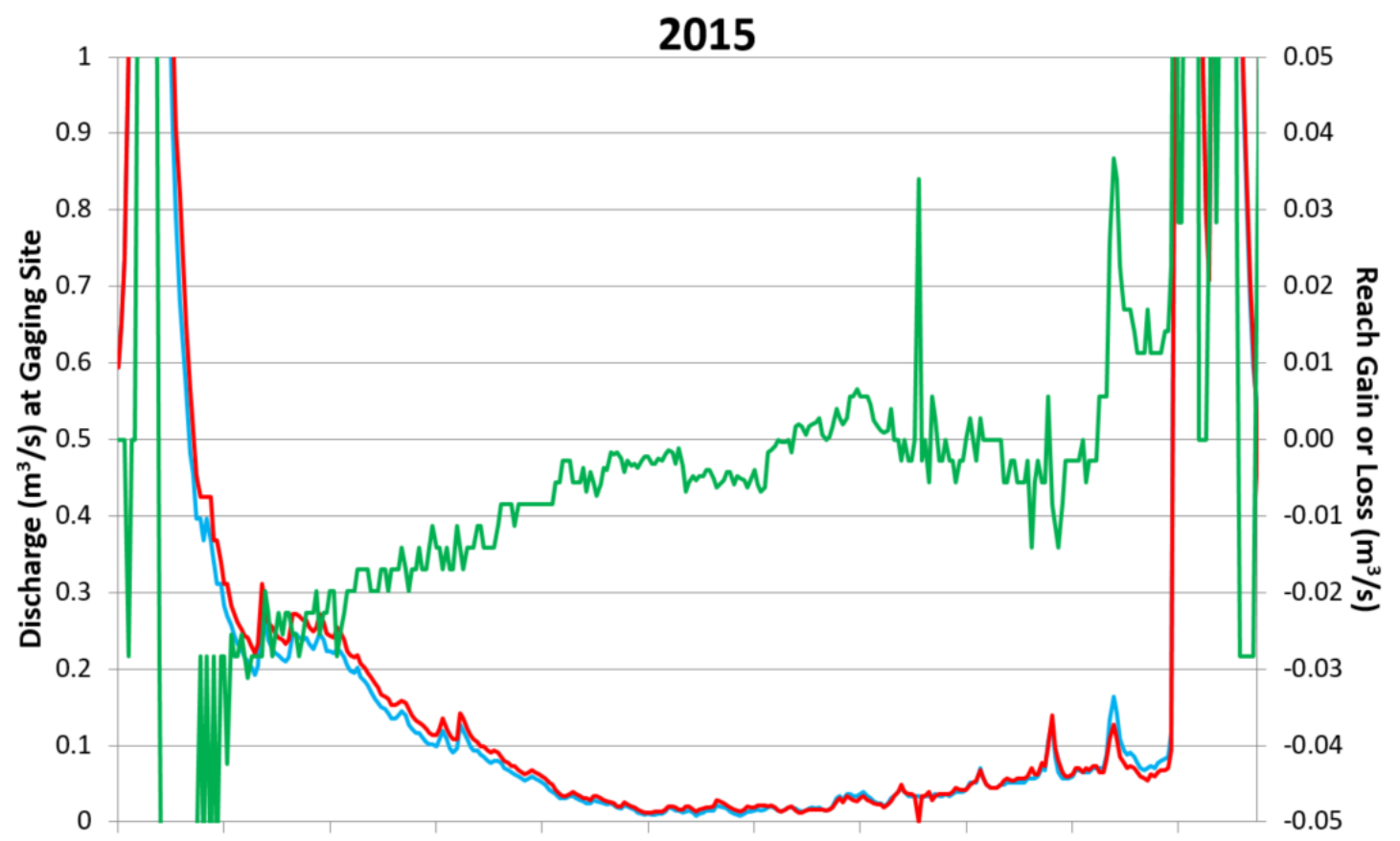

Feb-15 Mar-15 Apr-15 May-15 Jun-15 Jul-15 Aug-15 Sep-15 Oct-15 Nov-15 Dec-15

—lower gage —upper gage — gain/loss

Figure 52: Steam discharge data and gains/losses across the Lolo/Pomona aquifers in Mosier Creek from March 2015 through December 2015. 


\section{Chemical Hydrogeology}

A total of thirty-one water samples were collected from Mosier area wells, streams, and springs. Five samples were from springs at three different locations. Three samples were collected along Mosier Creek and one from West Fork Mosier Creek. Twenty-two samples were collected representing thirteen water wells with all but two wells containing multiple sample dates. Site location information and field parameters of $\mathrm{pH}$, temperature, and specific conductivity are presented in Table 4 and Figure 46.

\section{Major Element Chemistry}

Major-element chemistry is provided in Table 5 and Table 7, which includes the charge balance errors (CBEs). CBEs were calculated using PHREEQC except where alkalinity measurements were not recorded. All samples had CBEs less than $8 \%$ except for one with a CBE of $11.3 \%$; the average of CBEs for all samples is $0.73 \%$.

Specific conductance values were highest in wells samples, varying from 215 to $399 \mu \mathrm{S} / \mathrm{cm}$. Specific conductances for spring and stream samples varied from 178 to 235 and from 162 to $190 \mu \mathrm{S} / \mathrm{cm}$, respectively. Similarly, pH was highest in wells samples with a range of 6.77 to 8.25 . Values for $\mathrm{pH}$ were lowest in springs, 6.60 to 7.55, and relatively high in streams, 7.69 to 8.04 .

Creek temperatures were lowest, ranging from 7.9 to $9.9^{\circ} \mathrm{C}$, which is likely due to surface water sampling only taking place during October but not during the 
middle of summer. Temperature measurements for springs were similar, from 10.8 to $12.2^{\circ} \mathrm{C}$. The one outlier had a temperature of $17.6^{\circ} \mathrm{C}$, but this value is thought to either be due to measurement error or the result of stagnant water at the hottest time of year. The spring HarSpr was collected in late August and appeared to be stagnant as it is a very small spring. Well temperatures ranged from 13.0 to $18.2^{\circ} \mathrm{C}$ in the deepest well.

Several differentiation plots and figures were developed to further characterize the data. Most figures are split between sampling campaigns 1 (May to August 2012) and 2 (October 2012). Trilinear plots are used to classify waters on the basis of cationic and anionic species. As shown in Figure 53 and Figure 54, all samples are classified as mixed cation-bicarbonate waters. There appears to be a near-linear trend within the major cation plot, particularly for the October 2012 data, reflecting varying $\mathrm{Na}^{+}+\mathrm{K}^{+}$concentrations. Bicarbonate equivalent fractions are at or above $90 \%$ for each sample with two exceptions in each sampling campaign, Well 50811 and RowSpr.

The general major element chemistry is very similar according to the trilinear plots, especially for stream samples. To investigate the linear trend mentioned above and further investigate stream hydrochemistry, Schoeller and cation ratio plots were created (Figure 55 - Figure 63). Figure 55 and Figure 56 reveal the greatest range of variations in the concentrations of sulfate, potassium, sodium, and to a lesser extent magnesium. There are no discernable differences in concentrations between sampling campaigns. Figure 57 displays the ionic 
concentrations of stream samples, all of which were collected in October 2013. All Mosier Creek samples have very little variation between ionic concentrations. The West Fork Mosier Creek sample (WFRK) is differentiated from the Mosier Creek samples in that it generally has higher ionic concentrations.

Five variation diagrams (Figures 58 - 62) are provided to further investigate trends amongst the hydrochemical data. All plots have been split by sampling campaign with cation ratio $((\mathrm{Na}+\mathrm{K}) /(\mathrm{Na}+\mathrm{K}+\mathrm{Ca}+\mathrm{Mg}))$ plotted on the $\mathrm{x}$-axis, versus the elements of fluoride, sodium, potassium, magnesium, and chloride. The final diagram plots $\mathrm{pH}$ versus specific conductance.

Fluoride versus cation ratio plots (Figure 58) reveal the same defined linear trend within the data for both sampling campaigns. Additionally, when referenced against the sample location map (Figure 46), there appear to be groupings of wells based off of geographical location. All of the spring and surface water samples and well samples located higher in the watershed $(3016,3019,51025$, and 51831) plot in a grouping with low fluoride and cation ratio values; whereas, wells lower in the watershed, closer to the thrust fault $(2759,2765,50012,51497$, and 51778), all have higher fluoride and cation ratio values. Two wells located in the middle of the watershed, 2767 and 50250, have the highest cation ratios, with 50250 having the highest values by a large margin. It is worthy to note that in terms of elevation at the well, due to their location along Mosier Creek, WASC 2767 and 50250 are more similar to the elevation of lower watershed wells as opposed to the higher 
elevations of upper watershed wells. There is also a shift toward increasing cation ratio values for all samples from the first sampling campaign to the second.

One exception to the above groupings is WASC 50811, which shifts considerably between sampling campaigns and often does not fall within a particular grouping. In the fluoride plot, 50811 plots closer to the upper watershed wells in the first sampling campaign and closer to the lower watershed wells in the second sampling campaign.

The same linear trend and groupings revealed in the fluoride plot is also seen in the sodium and potassium versus cation ratio plots, although less pronounced. Well 2767 has the highest sodium and potassium concentrations in both sampling campaigns (Figure 59 and Figure 60).

The magnesium plot reveals the opposite linear trend from fluoride, where lower magnesium concentrations plot with higher cation ratio values (Figure 61). Additionally, there appears to be a linear trend with endmembers of WASC 50250 and 50811 in the first sampling campaign, and 51831 in the second sampling campaign. WASC 50250 has the lowest magnesium concentrations, while WASC 51831 has the highest magnesium concentration. Other than WASC 51831, all upper watershed wells and spring and stream samples plot off of the linear trend. There is considerably more scatter, especially in wells higher in the watershed, associated with the chloride plot (Figure 62). Again, WASC 50250 is distinguished as it has the lowest chloride concentration of all well samples. 
The last variation diagram consists of $\mathrm{pH}$ versus specific conductance (Figure 63). The wells located in the upper watershed display a wide range of values for $\mathrm{pH}$ and specific conductance, while lower watershed wells plot within a tight range. Specifically, the wells in the lower watershed completed in the Lolo and Rosalia aquifers are closely plotted with values near a $\mathrm{pH}$ of 8.2 and specific conductance of $325(\mu \mathrm{S} / \mathrm{cm})$. 
Table 4: Location information and summary of field parameters for well, stream, and spring samples.

\begin{tabular}{|c|c|c|c|c|c|c|c|}
\hline Name & $\begin{array}{c}\text { UTM } \\
\text { Northing } \\
\text { (m) } \\
\end{array}$ & $\begin{array}{c}\text { UTM } \\
\text { Easting } \\
(\mathrm{m})\end{array}$ & $\begin{array}{l}\text { Elevation } \\
\text { (m) }\end{array}$ & $\begin{array}{c}\text { Date } \\
(\mathrm{mo} / \mathrm{dd} / \mathrm{yr})\end{array}$ & $\begin{array}{c}\text { Temp } \\
\left({ }^{\circ} \mathrm{C}\right)\end{array}$ & pH & $\begin{array}{c}\text { Specific } \\
\text { Conductivity } \\
(\mu S / \mathrm{cm}) \\
\end{array}$ \\
\hline \multicolumn{8}{|l|}{ Wells } \\
\hline \multirow[t]{2}{*}{ WASC 2759} & 5059239 & 626229 & 118.2 & $06 / 11 / 12$ & 15.9 & 8.09 & 323.7 \\
\hline & & & & $10 / 10 / 12$ & 15.1 & 8.23 & 325.7 \\
\hline WASC 2765 & 5058883 & 625846 & 83.2 & $06 / 11 / 12$ & 16.6 & 8.06 & 325.2 \\
\hline \multirow[t]{2}{*}{ WASC 2767} & 5057672 & 626153 & 101.4 & $05 / 18 / 12$ & 14.0 & 8.11 & 385.0 \\
\hline & & & & $10 / 09 / 12$ & 14.0 & 8.18 & 399.1 \\
\hline \multirow[t]{2}{*}{ WASC 3016} & 5056914 & 627051 & 246.3 & $06 / 04 / 12$ & 16.4 & 7.78 & 299.0 \\
\hline & & & & $10 / 12 / 12$ & 17.0 & 7.70 & 293.9 \\
\hline \multirow[t]{2}{*}{ WASC 3019} & 5056547 & 628021 & 252.1 & $08 / 31 / 12$ & 14.8 & 6.77 & 224.0 \\
\hline & & & & $10 / 10 / 12$ & 13.4 & 6.89 & 218.4 \\
\hline \multirow[t]{2}{*}{ WASC 50012} & 5058970 & 626098 & 94.5 & $05 / 18 / 12$ & 15.7 & 8.04 & 325.0 \\
\hline & & & & $10 / 08 / 12$ & 15.7 & 8.09 & 324.6 \\
\hline \multirow[t]{2}{*}{ WASC 50250} & 5057694 & 626133 & 100.9 & $05 / 18 / 12$ & 17.7 & 8.16 & 278.5 \\
\hline & & & & $10 / 09 / 12$ & 17.2 & 8.22 & 279.9 \\
\hline \multirow[t]{2}{*}{ WASC 50811} & 5056523 & 626553 & 128.0 & $06 / 04 / 12$ & 12.9 & 7.84 & 358.6 \\
\hline & & & & $10 / 09 / 12$ & 13.0 & 8.08 & 355.1 \\
\hline \multirow[t]{2}{*}{ WASC 51025} & 5056578 & 628208 & 283.1 & $06 / 11 / 12$ & 16.8 & 7.44 & 275.7 \\
\hline & & & & $10 / 10 / 12$ & 17.5 & 7.53 & 215.3 \\
\hline \multirow[t]{2}{*}{ WASC 51497} & 5059270 & 625758 & 81.4 & $06 / 11 / 12$ & 16.0 & 8.10 & 324.7 \\
\hline & & & & $10 / 10 / 12$ & 15.1 & 8.25 & 325.0 \\
\hline \multirow[t]{2}{*}{ WASC 51778} & 5058947 & 625921 & 80.8 & $06 / 04 / 12$ & 13.8 & 7.96 & 376.6 \\
\hline & & & & $10 / 08 / 12$ & 14.2 & 8.12 & 377.9 \\
\hline WASC 51831 & 5057578 & 629853 & 389.5 & $10 / 12 / 12$ & 18.2 & 7.96 & 397.7 \\
\hline \multicolumn{8}{|l|}{ Creeks } \\
\hline MRCR1 & 5054235 & 626852 & 185.9 & $10 / 11 / 12$ & 9.4 & 7.94 & 163.5 \\
\hline MRCR2 & 5055817 & 626556 & 142.0 & $10 / 11 / 12$ & 9.9 & 8.04 & 162.0 \\
\hline MRCR3 & 5057859 & 626111 & 103.9 & $10 / 12 / 12$ & 7.9 & 7.69 & 167.1 \\
\hline WFRK & 5056223 & 626299 & 130.1 & $10 / 12 / 12$ & 7.9 & 7.84 & 189.2 \\
\hline \multicolumn{8}{|l|}{ Springs } \\
\hline \multirow[t]{2}{*}{ HarSpr } & 5056279 & 627984 & 206.9 & $08 / 31 / 12$ & 17.6 & 7.55 & 234.8 \\
\hline & & & & $10 / 09 / 12$ & 12.2 & 6.60 & 232.6 \\
\hline HudsonSpr & 5058900 & 625656 & 120.0 & $10 / 08 / 12$ & 11.7 & 6.73 & 230.8 \\
\hline \multirow[t]{2}{*}{ RowSpr } & 5060988 & 631574 & 85.0 & $08 / 31 / 12$ & 11.7 & 6.83 & 178.6 \\
\hline & & & & $10 / 10 / 12$ & 10.8 & 6.93 & 192.3 \\
\hline
\end{tabular}


Table 5: Major ion concentrations (mg/L) in water samples from wells in Mosier, 0R, 2012.

\begin{tabular}{|c|c|c|c|c|c|c|c|c|c|c|c|}
\hline Well Name & $\begin{array}{c}\text { Date } \\
\text { (mo/dd/yr) }\end{array}$ & Alkalinity & $\begin{array}{c}\text { Bicarbonate } \\
\left(\mathrm{HCO}_{3}^{-}\right)\end{array}$ & $\begin{array}{c}\begin{array}{c}\text { Calcium } \\
\left(\mathrm{Ca}^{2+}\right)\end{array} \\
\end{array}$ & $\begin{array}{c}\text { Magnesium } \\
\left(\mathrm{Mg}^{2+}\right)\end{array}$ & $\begin{array}{c}\begin{array}{c}\text { Sodium } \\
\left(\mathrm{Na}^{+}\right)\end{array} \\
\end{array}$ & $\begin{array}{c}\text { Potassium } \\
\left(\mathrm{K}^{+}\right)\end{array}$ & $\begin{array}{c}\begin{array}{c}\text { Fluoride } \\
\left(\mathrm{F}^{-}\right)\end{array} \\
\end{array}$ & $\begin{array}{c}\text { Chloride } \\
\left(\mathrm{Cl}^{-}\right)\end{array}$ & $\begin{array}{l}\text { Sulfate } \\
\left(\mathrm{SO}_{4}{ }^{2-}\right)\end{array}$ & $\begin{array}{c}\text { Silica } \\
\left(\mathrm{SiO}_{2}\right)_{\mathrm{aq}}\end{array}$ \\
\hline \multirow[t]{2}{*}{ "WASC 2759} & $06 / 11 / 12$ & 123.2 & 150.3 & 21.26 & 12.09 & 15.71 & 4.38 & 0.37 & 2.38 & 8.06 & 58 \\
\hline & $10 / 10 / 12$ & 138.0 & 168.4 & 20.46 & 13.66 & 18.35 & 4.02 & 0.45 & 2.38 & 8.74 & 64 \\
\hline WASC 2765 & $06 / 11 / 12$ & 146.0 & 178.1 & 22.50 & 10.61 & 17.44 & 5.18 & 0.42 & 2.39 & 7.88 & 58 \\
\hline \multirow[t]{2}{*}{ WASC 2767} & $05 / 18 / 12$ & 164.0 & 200.1 & 27.19 & 10.43 & 21.94 & 7.02 & 0.46 & 4.54 & 8.15 & 58 \\
\hline & $10 / 09 / 12$ & 166.0 & 202.5 & 26.07 & 12.52 & 25.69 & 6.57 & 0.49 & 4.25 & 9.50 & 65 \\
\hline \multirow[t]{2}{*}{ WASC 3016} & $06 / 04 / 12$ & 116.0 & 141.5 & 23.52 & 11.09 & 10.33 & 3.58 & 0.14 & 5.42 & 6.58 & 53 \\
\hline & $10 / 12 / 12$ & 106.0 & 129.3 & 22.22 & 12.73 & 11.90 & 2.96 & 0.19 & 4.69 & 6.78 & 65 \\
\hline \multirow[t]{2}{*}{ WASC 3019} & $08 / 31 / 12$ & 90.0 & 109.8 & 16.50 & 11.28 & 8.83 & 2.47 & 0.21 & 3.02 & 2.23 & 77 \\
\hline & $10 / 10 / 12$ & 90.0 & 109.8 & 15.39 & 10.53 & 8.56 & 2.30 & 0.20 & 2.75 & 2.16 & 79 \\
\hline \multirow[t]{2}{*}{ WASC 50012} & $05 / 18 / 12$ & 125.4 & 153.0 & 20.78 & 11.92 & 16.18 & 4.49 & 0.39 & 2.50 & 8.52 & 58 \\
\hline & $10 / 08 / 12$ & 138.0 & 168.4 & 20.03 & 13.66 & 18.85 & 4.02 & 0.43 & 2.35 & 8.72 & 63 \\
\hline \multirow[t]{2}{*}{ WASC 50250} & $05 / 18 / 12$ & 143.2 & 174.7 & 17.53 & 6.95 & 19.06 & 5.36 & 0.62 & 2.23 & 3.23 & 57 \\
\hline & $10 / 09 / 12$ & 134.0 & 163.5 & 17.21 & 7.88 & 22.47 & 4.82 & 0.62 & 2.20 & 3.40 & 64 \\
\hline \multirow[t]{2}{*}{ WASC 50811} & $06 / 04 / 12$ & 127.0 & 154.9 & 25.69 & 14.92 & 13.71 & 4.69 & 0.23 & 3.32 & 27.94 & 47 \\
\hline & $10 / 09 / 12$ & 127.0 & 154.9 & 23.24 & 15.49 & 17.78 & 4.43 & 0.34 & 2.83 & 29.10 & 54 \\
\hline \multirow[t]{2}{*}{ WASC 51025} & $06 / 11 / 12$ & 98.0 & 119.6 & 18.56 & 12.49 & 9.70 & 3.38 & 0.15 & 4.17 & 1.82 & 70 \\
\hline & $10 / 10 / 12$ & 95.2 & 116.1 & 13.38 & 10.65 & 9.40 & 2.48 & 0.22 & 3.64 & 1.27 & 77 \\
\hline \multirow[t]{2}{*}{ WASC 51497} & $06 / 11 / 12$ & 118.0 & 144.0 & 22.05 & 10.95 & 16.91 & 4.82 & 0.47 & 2.42 & 8.02 & 57 \\
\hline & $10 / 10 / 12$ & 128.0 & 156.2 & 21.20 & 12.37 & 19.83 & 4.46 & 0.44 & 2.31 & 8.05 & 64 \\
\hline \multirow[t]{2}{*}{ WASC 51778} & $06 / 04 / 12$ & 134.0 & 163.5 & 27.19 & 12.1 & 18.30 & 5.8 & 0.4 & 3.91 & 9.51 & 56 \\
\hline & $10 / 08 / 12$ & 139.2 & 169.8 & 26.08 & 13.87 & 21.78 & 5.28 & 0.39 & 3.66 & 9.76 & 64 \\
\hline WASC 51831 & $10 / 12 / 12$ & 150.0 & 183.0 & 26.56 & 19.57 & 16.80 & 3.62 & 0.28 & 3.05 & 18.20 & 70 \\
\hline
\end{tabular}


Table 6: Minor and trace element total ion concentrations (ug/L; except $\mathrm{HPO}_{4}$ and $\mathrm{NO}_{3}$, which are in mg/L) in water samples from wells in Mosier, OR, 2012. Blank cells indicate that the concentration is below detection limit. Also shown are speciated charge balance errors (C.B.E. \%) for each sample calculated with PhreeqC.

\begin{tabular}{|c|c|c|c|c|c|c|c|c|c|c|}
\hline Well Name & $\begin{array}{c}\text { Date } \\
\text { (mo/dd/yr) } \\
\end{array}$ & $\begin{array}{l}\text { Phosphate } \\
\left(\mathrm{HPO}_{4}{ }^{2-}\right) \\
\end{array}$ & $\begin{array}{l}\text { Nitrate } \\
\left(\mathrm{NO}_{3}^{-}\right) \\
\end{array}$ & $\begin{array}{c}\text { Aluminum } \\
\left(\mathrm{Al}^{3+}\right) \\
\end{array}$ & $\begin{array}{c}\text { Barium } \\
\left(\mathrm{Ba}^{2+}\right) \\
\end{array}$ & $\begin{array}{c}\text { Iron } \\
\left(\mathrm{Fe}^{2+}\right) \\
\end{array}$ & $\begin{array}{c}\text { Manganese } \\
\left(\mathrm{Mn}^{2+}\right)\end{array}$ & $\begin{array}{c}\text { Strontium } \\
\left(\mathrm{Sr}^{2+}\right) \\
\end{array}$ & $\begin{array}{c}\text { Zinc } \\
\left(\mathrm{Zn}^{2+}\right) \\
\end{array}$ & C.B.E. (\%) \\
\hline \multirow{2}{*}{ WASC 2759} & $06 / 11 / 12$ & 0.27 & & 2.7 & 41 & 158 & 38 & 67 & 151 & 2.73 \\
\hline & $10 / 10 / 12$ & 0.18 & 0.72 & 3.4 & 130.3 & 156.4 & 45 & 73 & 103 & -0.37 \\
\hline WASC 2765 & $06 / 11 / 12$ & 0.25 & & 3.6 & 37 & 52 & 47 & 71 & 137 & -4.63 \\
\hline \multirow[t]{2}{*}{ WASC 2767} & $05 / 18 / 12$ & & & 2.4 & 43 & 95 & 57 & 86 & 216 & -3.47 \\
\hline & $10 / 09 / 12$ & & 0.70 & 11.1 & 55.0 & 8.4 & 2.0 & 93 & 6 & -1.26 \\
\hline \multirow[t]{2}{*}{ WASC 3016} & $06 / 04 / 12$ & 0.32 & 0.27 & 3.1 & 18 & & 3.3 & 77 & 168 & 0.00 \\
\hline & $10 / 12 / 12$ & 0.19 & 0.75 & 3.3 & 23.5 & & 0.6 & 82 & 77 & 5.85 \\
\hline \multirow[t]{2}{*}{ WASC 3019} & $08 / 31 / 12$ & 0.61 & 1.30 & 3.3 & 14.5 & & 1.6 & 93 & 553 & balanced on Alkalinity \\
\hline & $10 / 10 / 12$ & 0.82 & 1.40 & & 27.5 & & 0.9 & 88 & 662 & 1.39 \\
\hline \multirow[t]{2}{*}{ WASC 50012} & $05 / 18 / 12$ & 0.28 & & 2.9 & 29 & 125 & 62 & 65 & 99 & 1.34 \\
\hline & $10 / 08 / 12$ & 0.08 & 0.70 & 2.1 & 29.1 & 172.2 & 61 & 67 & 131 & -0.29 \\
\hline \multirow[t]{2}{*}{ WASC 50250} & $05 / 18 / 12$ & & & 3.5 & 23 & & 25 & 57 & 146 & -11.32 \\
\hline & $10 / 09 / 12$ & 0.07 & 0.71 & 8.7 & 45.9 & 83.2 & 27 & 60 & 94 & -5.12 \\
\hline \multirow[t]{2}{*}{ WASC 50811} & $06 / 04 / 12$ & 0.23 & & 2.1 & 26 & 53 & 17 & 75 & 234 & balanced on Alkalinity \\
\hline & $10 / 09 / 12$ & 0.06 & 0.81 & 2.1 & 29.2 & 48.3 & 42 & 78 & 67 & balanced on Alkalinity \\
\hline \multirow[t]{2}{*}{ WASC 51025} & $06 / 11 / 12$ & 0.49 & 0.25 & 2.5 & 19 & & 1.5 & 74 & 460 & 7.45 \\
\hline & $10 / 10 / 12$ & 0.43 & 1.72 & 4.0 & 15.9 & 4.5 & 1.6 & 65 & 232 & -3.39 \\
\hline \multirow[t]{2}{*}{ WASC 51497} & $06 / 11 / 12$ & 0.22 & & 2.1 & 36 & 136 & 50 & 72 & 475 & 4.95 \\
\hline & $10 / 10 / 12$ & 0.12 & & 2.4 & 51.4 & 244.8 & 50 & 79 & 97 & 4.45 \\
\hline \multirow[t]{2}{*}{ WASC 51778} & $06 / 04 / 12$ & 0.25 & & 2.1 & 61 & 117 & 74 & 97 & 44 & 4.82 \\
\hline & $10 / 08 / 12$ & 0.05 & 0.77 & 3.7 & 57.5 & 125.0 & 73 & 100 & 79 & 5.74 \\
\hline WASC 51831 & $10 / 12 / 12$ & 0.07 & & 3.0 & 20.4 & 59.4 & 64 & 78 & & 4.11 \\
\hline
\end{tabular}


Table 7: Major ion concentrations (mg/L) in spring and stream samples in Mosier, $\mathrm{OR}, 2012$. Blank cells indicate that the concentration is below detection limit.

\begin{tabular}{|c|c|c|c|c|c|c|c|c|c|c|c|}
\hline Sample Name & $\begin{array}{c}\text { Date } \\
(\mathrm{mo} / \mathrm{dd} / \mathrm{yr}) \\
\end{array}$ & Alkalinity & $\begin{array}{c}\text { Bicarbonate } \\
\left(\mathrm{HCO}_{3}^{-}\right) \\
\end{array}$ & $\begin{array}{c}\text { Calcium } \\
\left(\mathrm{Ca}^{2+}\right) \\
\end{array}$ & $\begin{array}{c}\text { Magnesium } \\
\left(\mathrm{Mg}^{2+}\right) \\
\end{array}$ & $\begin{array}{c}\text { Sodium } \\
\left(\mathrm{Na}^{+}\right)\end{array}$ & $\begin{array}{c}\text { Potassium } \\
\left(\mathrm{K}^{+}\right) \\
\end{array}$ & $\begin{array}{c}\text { Fluoride } \\
\left(\mathrm{F}^{-}\right)\end{array}$ & $\begin{array}{c}\text { Chloride } \\
\left(\mathrm{Cl}^{-}\right)\end{array}$ & $\begin{array}{l}\text { Sulfate } \\
\left(\mathrm{SO}_{4}^{2-}\right) \\
\end{array}$ & $\begin{array}{c}\text { Silica } \\
\left(\mathrm{SiO}_{2}\right)_{\mathrm{aq}} \\
\end{array}$ \\
\hline \multirow[t]{2}{*}{ HarSpr } & "08/31/12 & 105.0 & 128.1 & 14.92 & 11.74 & 9.70 & 3.81 & 0.23 & 3.71 & 1.03 & 78 \\
\hline & $10 / 09 / 12$ & 100.0 & 122.0 & 16.79 & 10.09 & 9.91 & 2.79 & 0.15 & 4.65 & 1.28 & 59 \\
\hline HudSpr & $10 / 08 / 12$ & 102.0 & 124.4 & 15.82 & 12.00 & 9.50 & 2.66 & 0.16 & 3.02 & 1.65 & 83 \\
\hline \multirow[t]{2}{*}{ RowSpr } & $08 / 31 / 12$ & 52.0 & 63.4 & 13.44 & 6.83 & 7.27 & 2.03 & 0.15 & 4.64 & 6.79 & 45 \\
\hline & $10 / 10 / 12$ & 62.0 & 75.6 & 14.40 & 7.32 & 7.45 & 2.06 & 0.15 & 5.31 & 7.79 & 46 \\
\hline MRCR1 & $10 / 11 / 12$ & 72.0 & 87.8 & 12.03 & 7.55 & 7.21 & 1.62 & 0.13 & 1.64 & 0.31 & 50 \\
\hline MRCR2 & $10 / 11 / 12$ & 64.0 & 78.1 & 11.98 & 7.45 & 7.42 & 1.80 & 0.13 & 1.83 & 0.36 & 51 \\
\hline MRCR3 & $10 / 12 / 12$ & 72.0 & 87.8 & 12.36 & 7.58 & 7.45 & 1.71 & 0.13 & 1.78 & 0.49 & 50 \\
\hline WFrk & $10 / 12 / 12$ & 82.0 & 100.0 & 13.90 & 8.37 & 8.75 & 2.37 & 0.14 & 2.31 & 0.37 & 59 \\
\hline
\end{tabular}

Table 8: Minor and trace element ion concentrations (ug/L; except $\mathrm{HPO}_{4}$ and $\mathrm{NO}_{3}$, which are in $\mathrm{mg} / \mathrm{L}$ ) in spring and stream samples in Mosier, OR, 2012. Blank cells indicate that the concentration is below detection limit. Also shown are speciated charge balance errors (C.B.E. \%) for each sample calculated with PhreeqC.

\begin{tabular}{|c|c|c|c|c|c|c|c|c|c|c|}
\hline Sample Name & $\begin{array}{c}\text { Date } \\
\text { (mo/dd/yr) }\end{array}$ & $\begin{array}{c}\text { Phosphate } \\
\left(\mathrm{HPO}_{4}^{2-}\right)\end{array}$ & $\begin{array}{c}\text { Nitrate } \\
\left(\mathrm{NO}_{3}^{-}\right) \\
\end{array}$ & $\begin{array}{c}\text { Aluminum } \\
\left(\mathrm{Al}^{3+}\right)\end{array}$ & $\begin{array}{c}\text { Barium } \\
\left(\mathrm{Ba}^{2+}\right) \\
\end{array}$ & $\begin{array}{c}\text { Iron } \\
\left(\mathrm{Fe}^{2+}\right) \\
\end{array}$ & $\begin{array}{c}\text { Manganese } \\
\left(\mathrm{Mn}^{2+}\right)\end{array}$ & $\begin{array}{c}\text { Strontium } \\
\left(\mathrm{Sr}^{2+}\right)\end{array}$ & $\begin{array}{c}\text { Zinc } \\
\left(\mathrm{Zn}^{2+}\right) \\
\end{array}$ & C.B.E. (\%) \\
\hline \multirow[t]{2}{*}{ HarSpr } & $08 / 31 / 12$ & 0.52 & & 15.7 & 14.5 & 46.5 & 19 & 79 & 86 & balanced on Alkalinity \\
\hline & $10 / 09 / 12$ & 0.48 & & 28.4 & 34.5 & 36.4 & 30 & 120 & 78 & balanced on Alkalinity \\
\hline HudSpr & $10 / 08 / 12$ & 0.28 & 1.88 & & 13.6 & & & 124 & 111 & -0.80 \\
\hline \multirow{2}{*}{ RowSpr } & 08/31/12 & 0.07 & 4.54 & 6.6 & 18.2 & 5.8 & 2.6 & 83 & 92 & -1.14 \\
\hline & $10 / 10 / 12$ & 0.06 & 5.97 & 3.6 & 20.2 & 9.5 & 9.3 & 89 & 69 & -7.73 \\
\hline MRCR1 & $10 / 11 / 12$ & & & 3.8 & 10.6 & 16.6 & 1.2 & 128 & 74 & 2.77 \\
\hline MRCR2 & $10 / 11 / 12$ & & 0.73 & 4.5 & 11.2 & 15.6 & 2.0 & 126 & 5 & 6.33 \\
\hline MRCR3 & $10 / 12 / 12$ & 0.04 & & 4.9 & 12.7 & 53.2 & 2.1 & 124 & 76 & 3.55 \\
\hline WFrk & $10 / 12 / 12$ & 0.12 & & 7.5 & 18.9 & 44.5 & 6.1 & 128 & 80 & 3.21 \\
\hline
\end{tabular}


Sampling Campaign 1

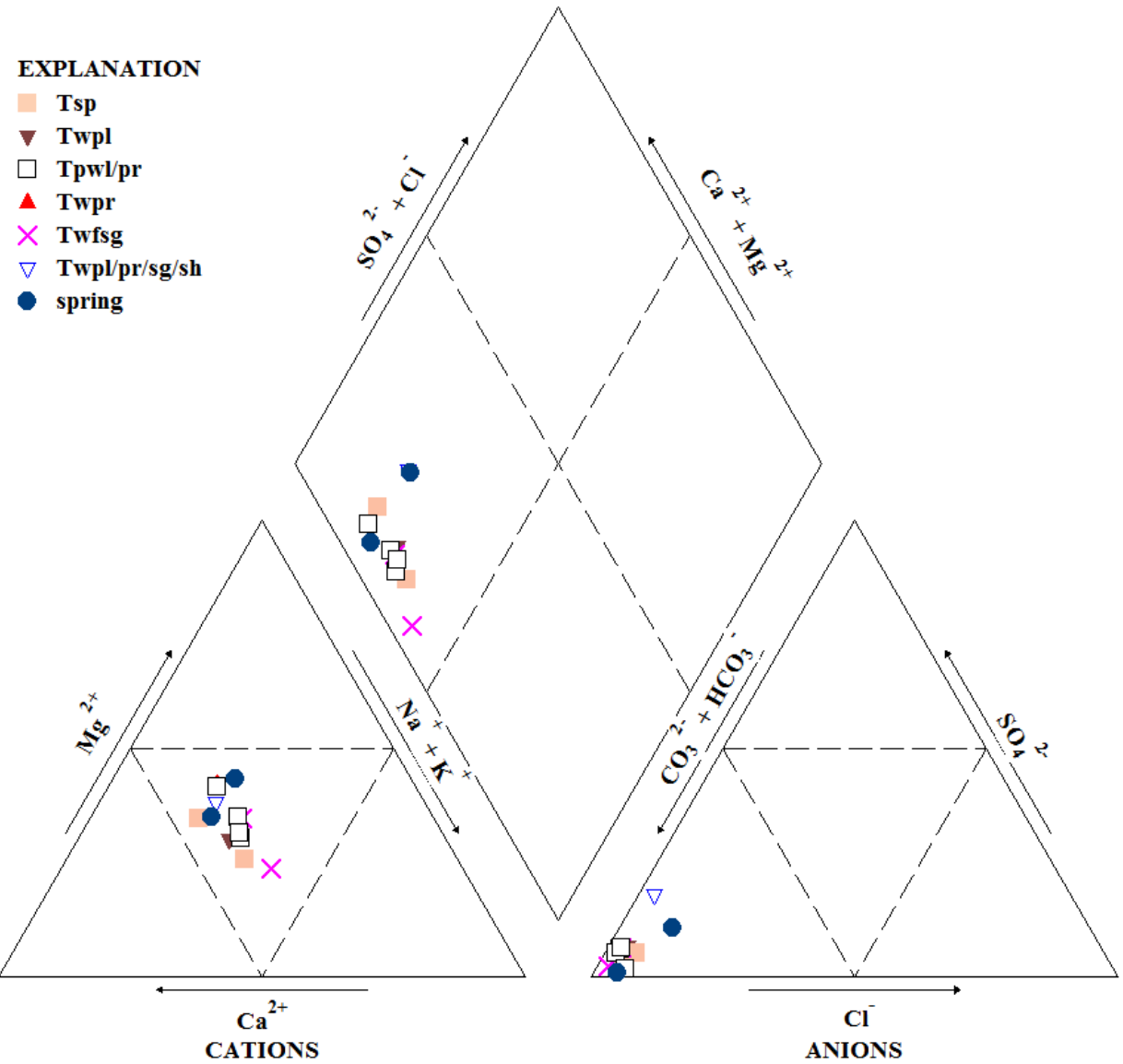

Figure 53: Piper diagram for all wells and springs sampled during sampling campaign 1 (May-August 2012). All samples plot as mixed cation - bicarbonate waters. See Figure 46 for sample locations. 
Sampling Campaign 2

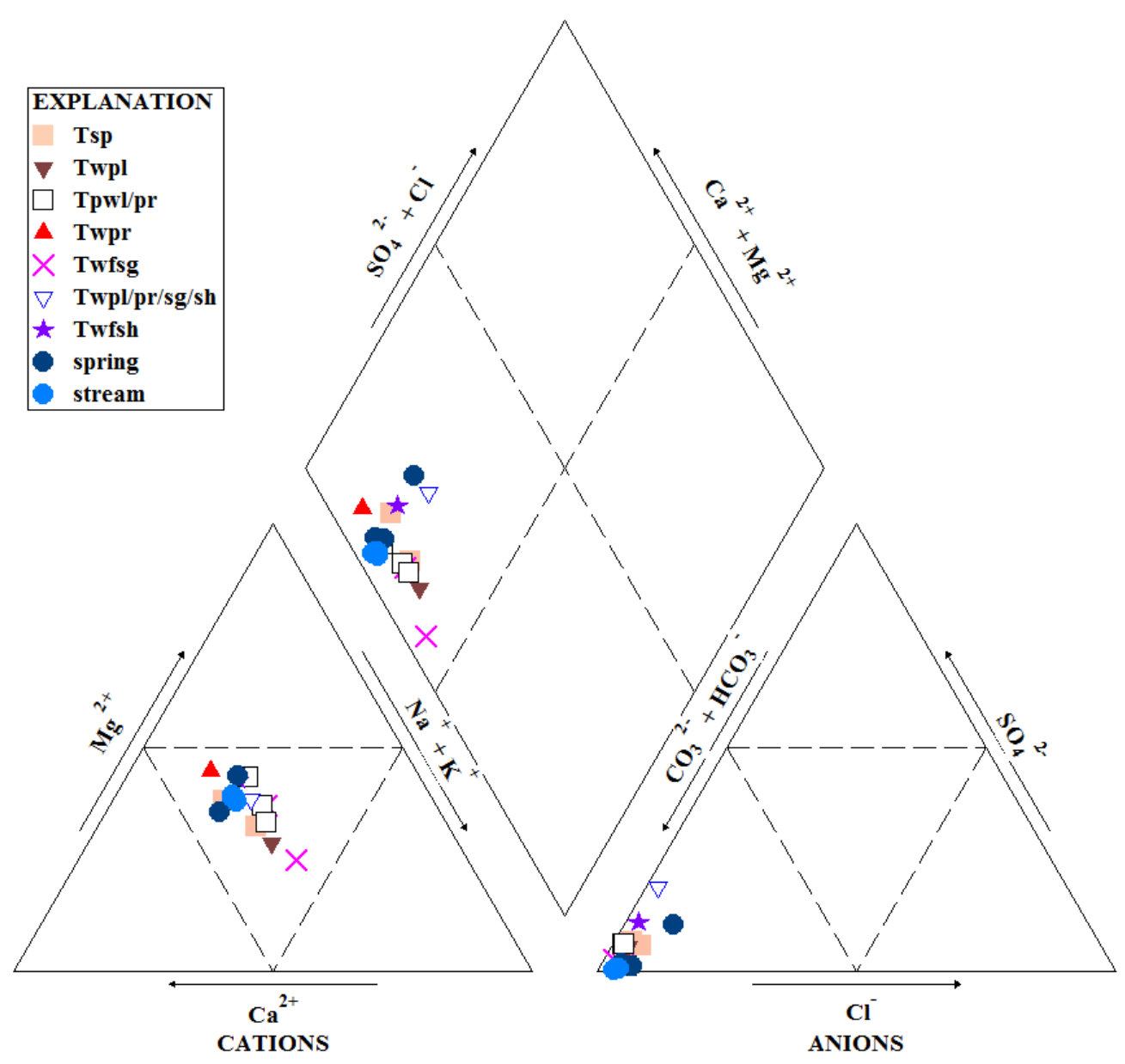

Figure 54: Piper diagram for all wells, springs, and streams sampled in sampling campaign 2 (October 2012). All samples plot as mixed cation - bicarbonate waters. See Figure 46 for sample locations. 


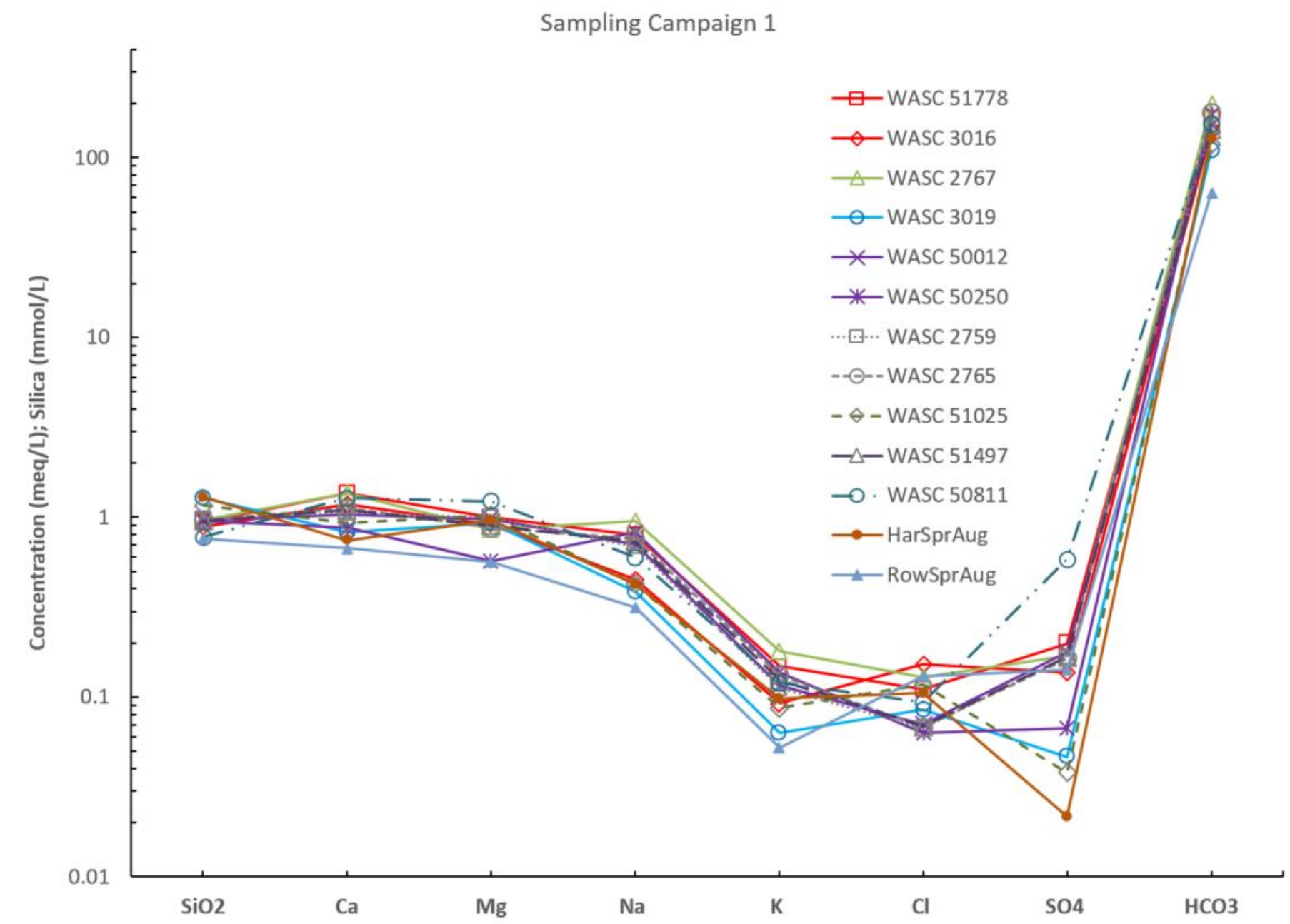

Figure 55: Ionic concentrations for all wells and springs sampled during Campaign 1 (May - August 2012). See Figure 46 for sample locations. 
Sampling Campaign 2

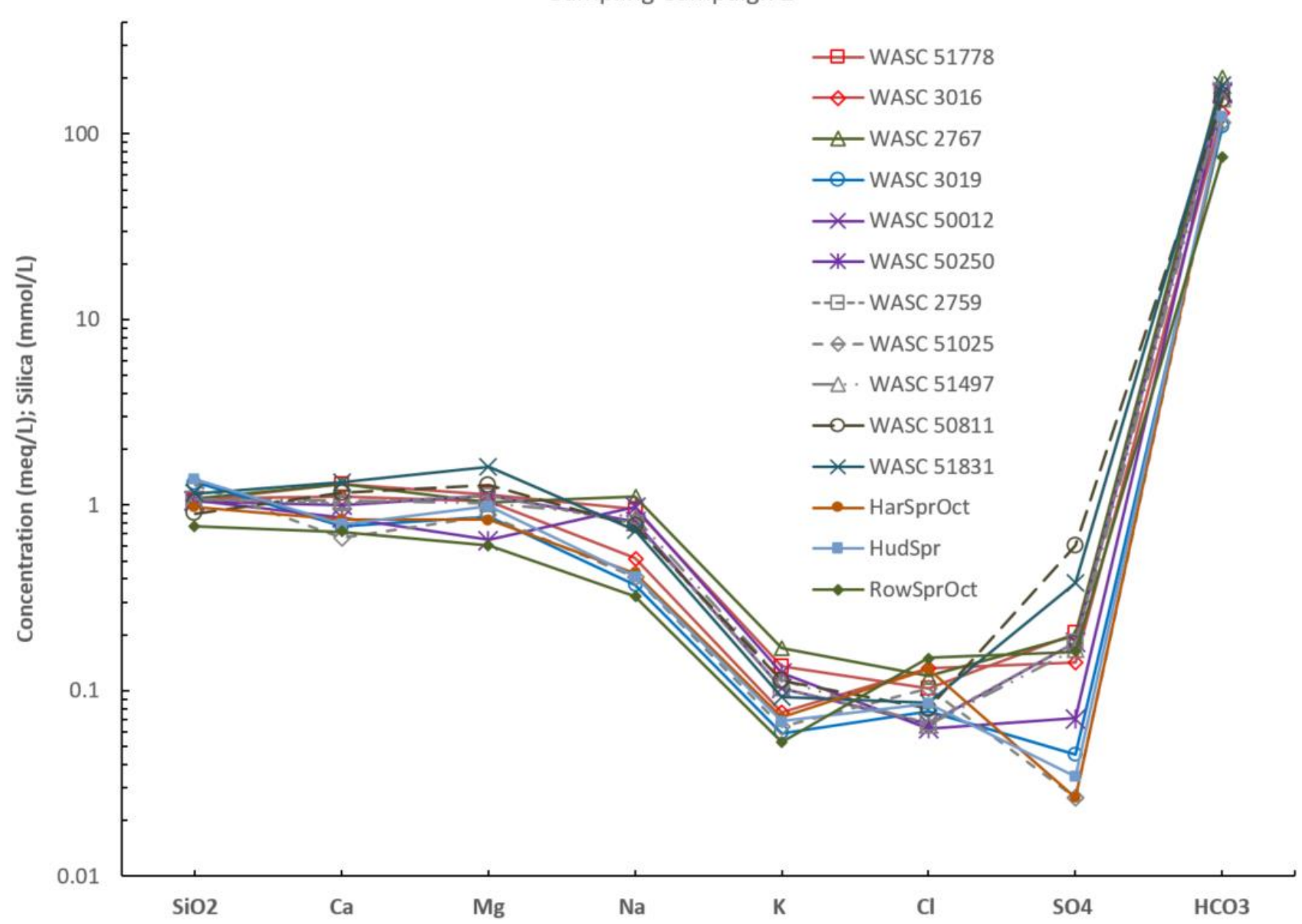

Figure 56: Ionic concentrations for all samples collected during sampling campaign 2 (October 2012). See Figure 46 for sample locations. 


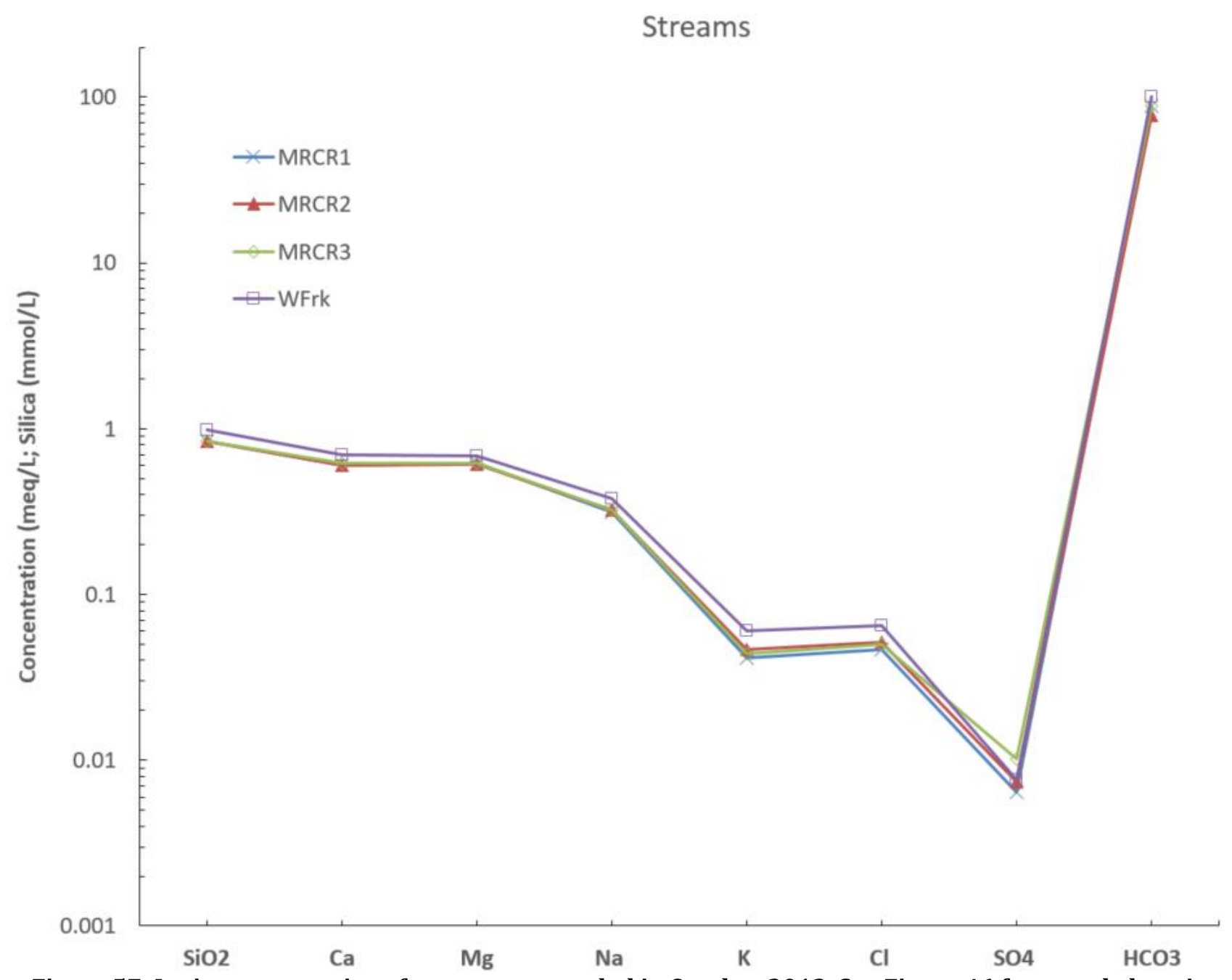

Figure 57: Ionic concentrations for streams sampled in October 2012. See Figure 46 for sample locations. 


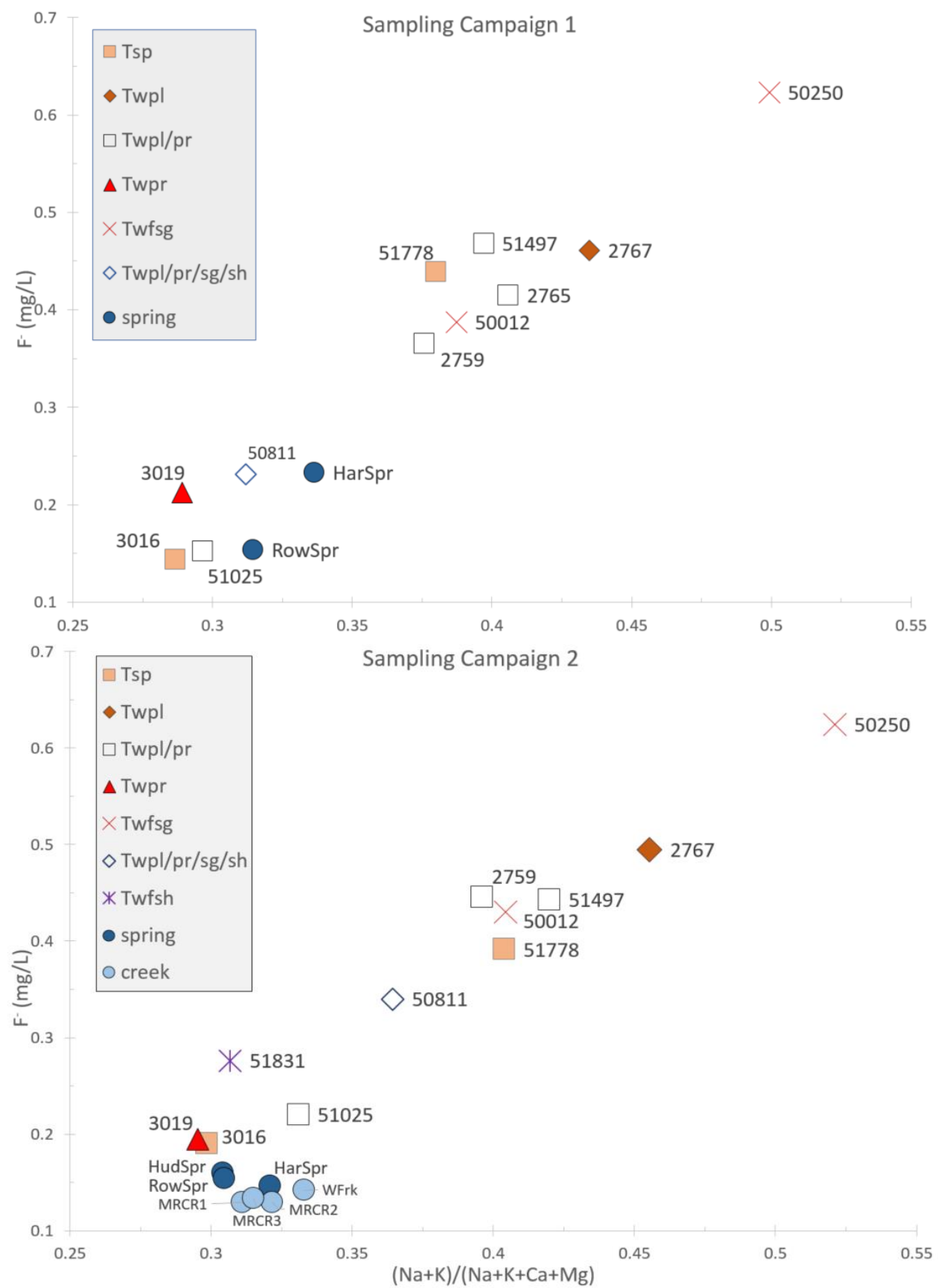

Figure 58: Cation Ratio vs F- for Sampling Campaigns 1 and 2. 


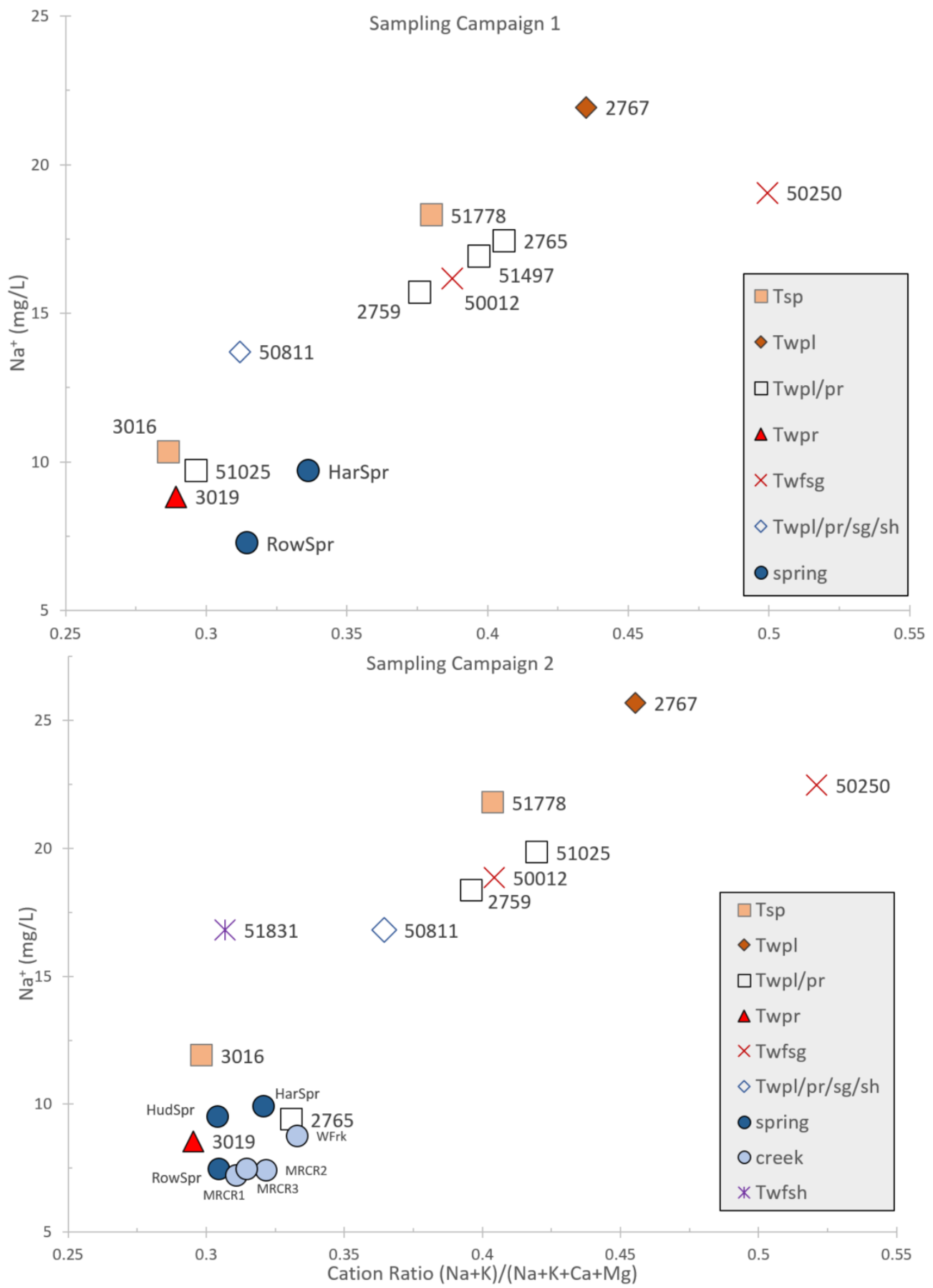

Figure 59: Cation Ratio vs $\mathrm{Na}^{+}$plots divided by sampling campaign. 


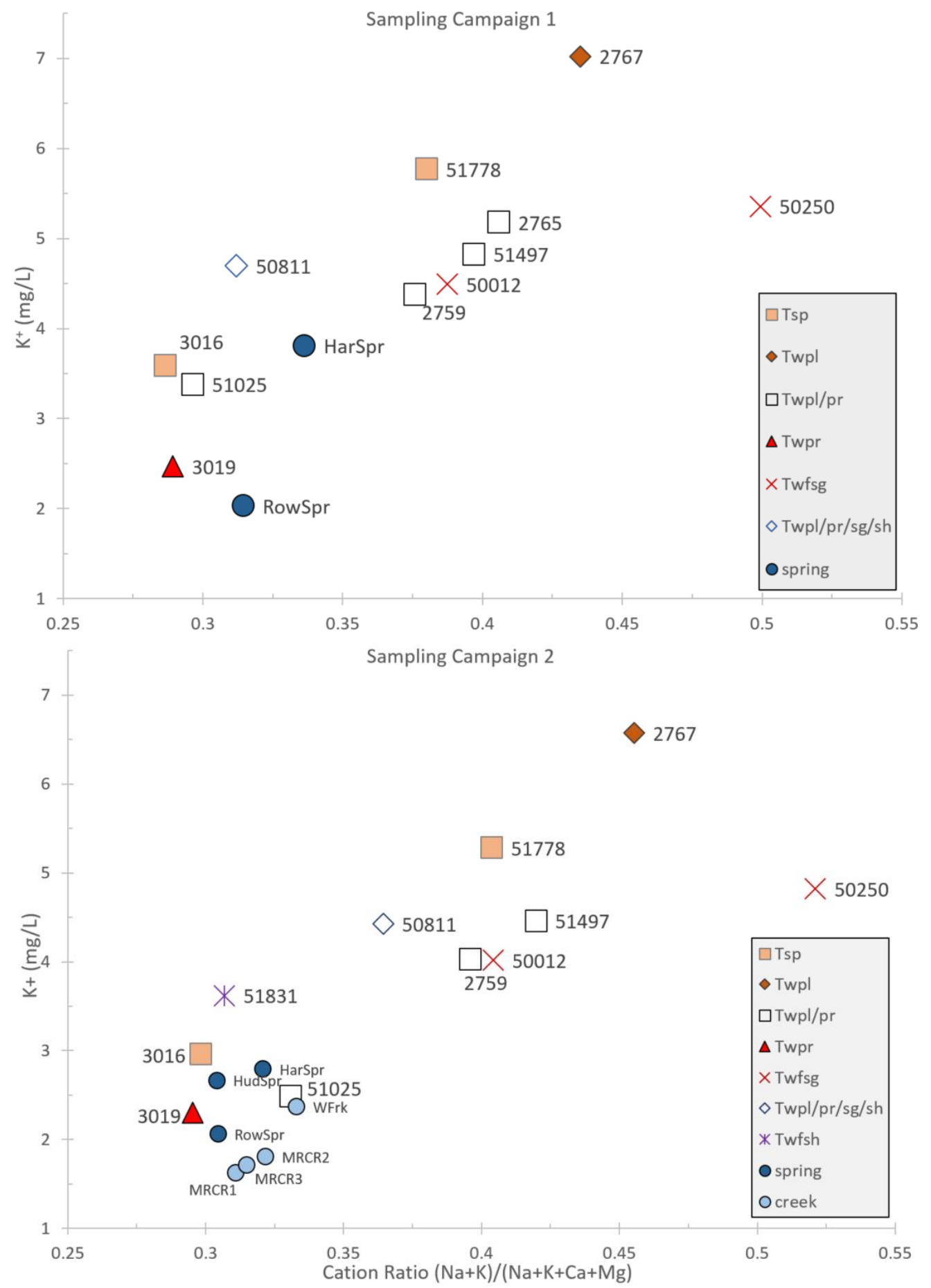

Figure 60: Cation Ratio vs $\mathrm{K}^{+}$for each sampling campaign. 

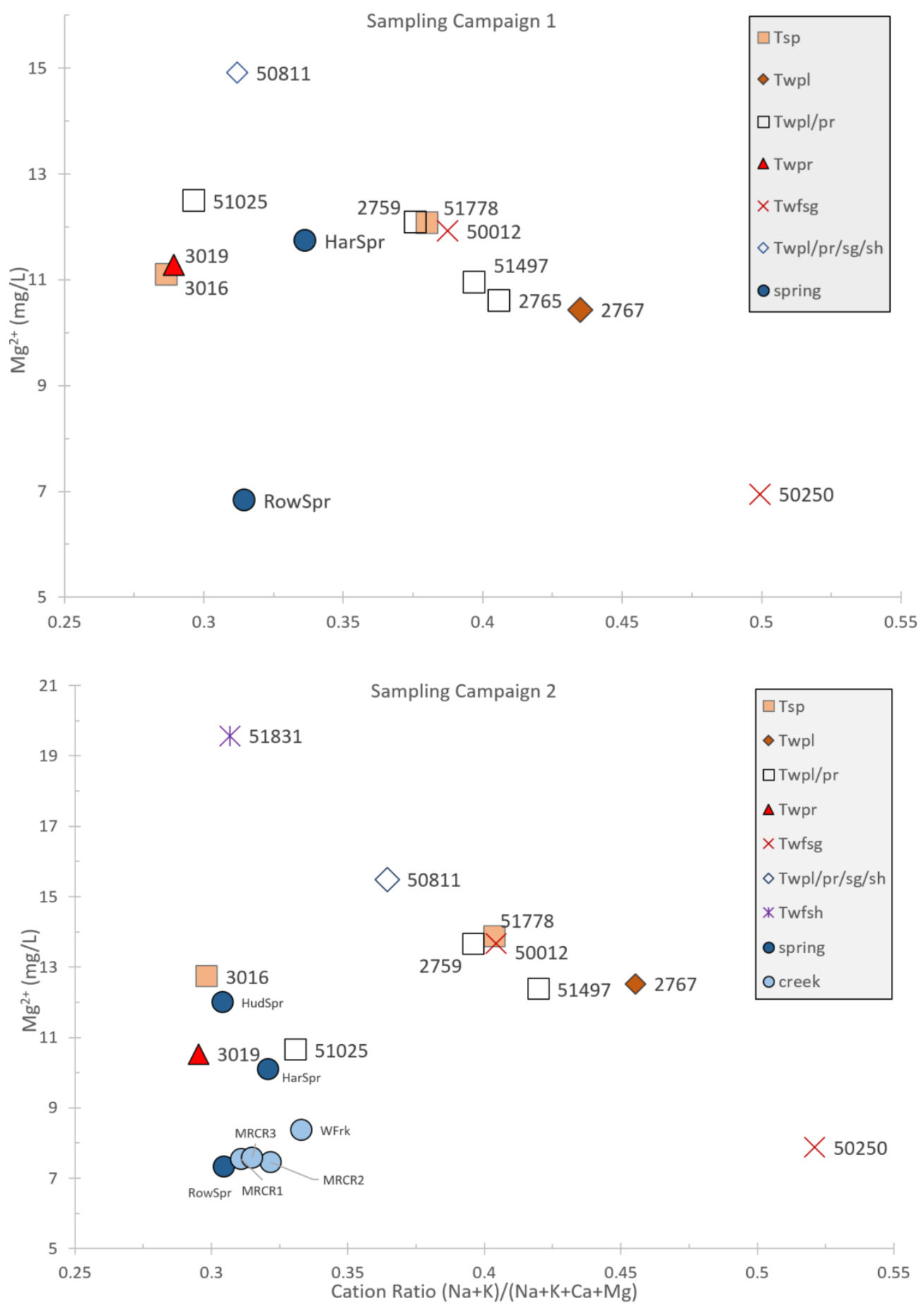

Figure 61: Cation Ratio vs $\mathrm{Mg}^{2+}$ for each sampling campaign. 


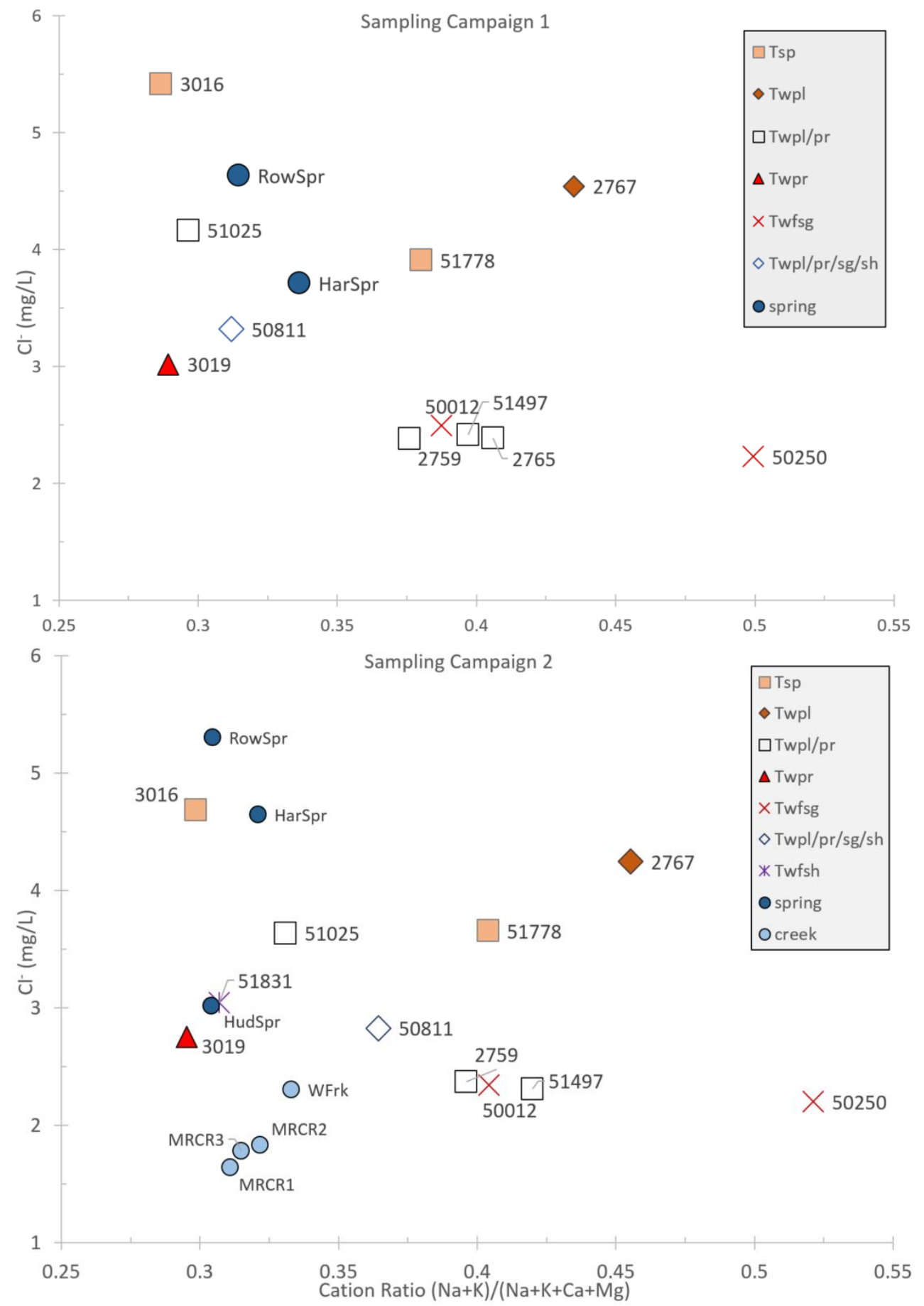

Figure 62: Cation Ratio vs $\mathrm{Cl}^{-}$for each sampling campaign. 


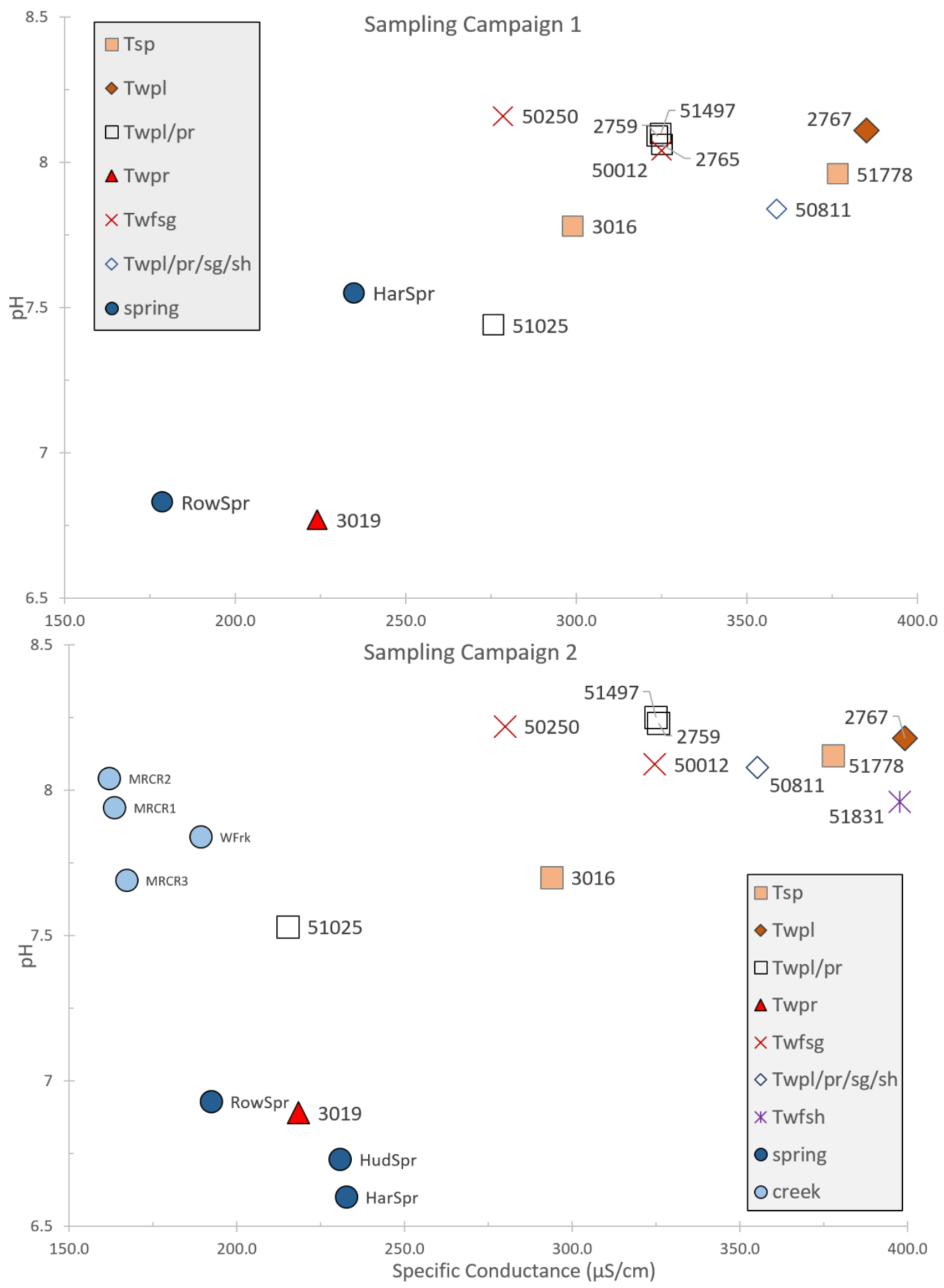

Figure 63: Specific Conductance vs pH plot for each sampling campaign. 


\section{Stable Isotopes}

Ten samples were analyzed for stable hydrogen and oxygen isotopes, including five wells, two streams, and three springs, all collected in October 2013. Isotope data are reported in delta values (\%o) relative to Vienna Standard Mean Ocean Water (VSMOW) (Table 9). Well samples were the most depleted in the heavy isotopes with $\delta \mathrm{D}$ and $\delta^{18} 0$ values ranging from -100.45 to $-108.90 \%$ and -13.44 to -14.38 , respectively. Spring and stream ratios ranged from -93.27 to $-95.01 \%$ for $\delta D$ and -12.14 to $-12.92 \%$ for $\delta^{18} 0$.

Table 9: Stable Isotope concentrations of $\delta^{18} 0$ and $\delta D$ in standard \%o notation.

\begin{tabular}{llll}
\hline \hline Sample/Site & Sample Type/Aquifer & $\delta^{2} \mathrm{H}(\% \mathrm{o})$ & $\delta^{18} \mathrm{O}(\% \mathrm{0})$ \\
\hline \hline HAR Spr & Spring: Lolo & -93.27 & -12.14 \\
HUD Spr & Spring: Dalles Fm. & -93.28 & -12.52 \\
ROW Spr & Spring: Sentinel Gap & -93.60 & -12.46 \\
MRCR3 & Stream Sample & -94.92 & -12.94 \\
WFRK & Stream Sample & -95.01 & -12.62 \\
WASC 50012 & Sentinel Gap & -106.39 & -14.18 \\
WASC 51497 & Lolo and Rosalia & -102.22 & -13.62 \\
WASC 51778 & Pomona & -100.45 & -13.44 \\
WASC 51831 & Sand Hollow & -102.01 & -13.79 \\
WASC 50250 & Sentinel Gap & -108.90 & -14.38 \\
\hline
\end{tabular}

Isotopic compositions of the samples are plotted relative to the Global Meteoric Water Line (GMWL) in Figure 64. Samples for this study plot on a line $\left(R^{2}=0.95\right)$ given by $\delta^{2} H=7.2 \delta^{18} \mathrm{O}-3.2$, which has a slightly lower slope than the GMWL. The most isotopically depleted wells are 50012 and 50250, both completed in the Sentinel Gap aquifer. Three other wells, 51497, 51778, and 51831, plot in a separate grouping, being more isotopically enriched than WASCO 50012 and 50250 but more depleted than the stream and spring samples. 
For reference, isotopic ratios from Ingebritsen et al. (1988), James (1999), and Nathenson (2004), were included in the plot. The plotted data from James contains only samples from east of the Cascades. The associated LMWL has a lower slope than the GMWL. Ingebritsen et al.'s (1988) data includes samples from east and west of the Cascades; however, only the data from the eastern Cascades was included in the drawing of the LMWL for Figure 64. Ingebritsen et al.'s LMWL is not labeled in the figure as it is coincident with James' (1999) LMWL, differing only slightly with a higher slope. Nathenson's (2004) data are from Mt. Hood and have the same slope as the GMWL. This is due to the means by which the LMWL was developed for the study. Nathenson (2004) did not have precipitation data to develop a LMWL. Instead, it was inferred that the most enriched spring sample represents local, modern recharge, so the LMWL was fixed at a slope of 8 and adjusted to the location of the most enriched spring sample. 


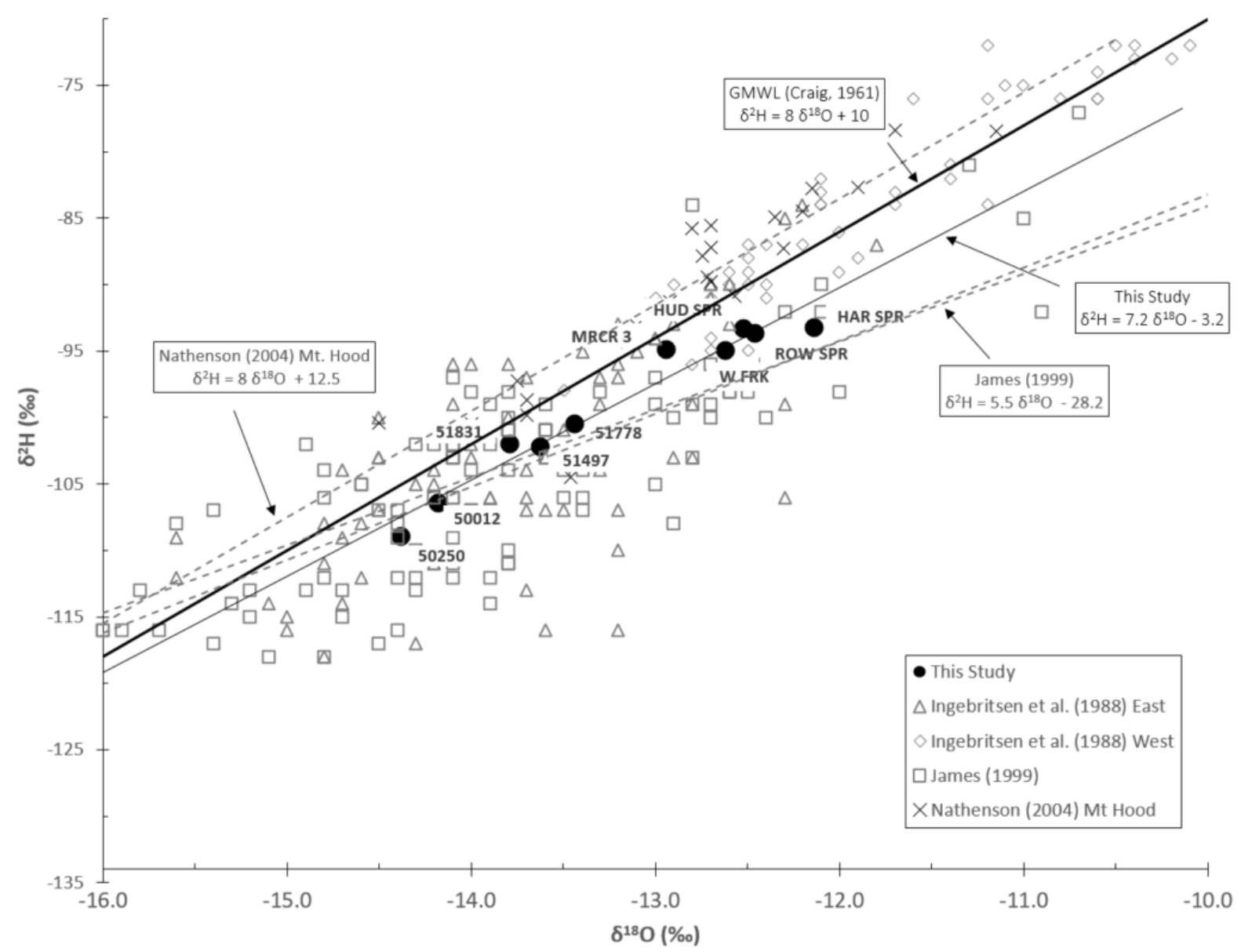

Figure 64: $\delta^{2} \mathrm{H}$ vs $\delta^{18} \mathrm{O}$ plot for samples from this study along with other study results from the Oregon Cascades for comparison. Sample locations for this study were provided in Figure 46. The Global Meteoric Water Line and Local Meteoric Water Lines are displayed for each study (Craig, 1961, Ingebritsen et al., 1988, James, 1999, and Nathenson (2004). 


\section{Discussion}

The discussion below begins with the determinations made from groundwater level data and stream discharge data as they relate to the geologic mapping presented in Chapter 2. Subsequently, the results and implications of the chemical hydrogeologic data are discussed, which includes the data analysis of elemental chemistry and isotope chemistry.

\section{Physical Hydrogeology}

The groundwater elevation data reveals an approximate elevation of 98 to $100 \mathrm{~m}$ at the inflection point, or flattening of the decline trend, seen in lower aquifer wells in 2004. The 100 m elevation is coincident with the geologic mapping results for the general elevation of the Pomona interflow zone. This zone, at the base of the Pomona flow, is exposed in the creek bed from approximately 100 to $106 \mathrm{~m}$. As discussed previously, the Selah interbed thins out away from the Mosier syncline, and the relatively thin interbed is not present in this location as it has been scoured out by Mosier Creek. The Lolo interflow zone was exposed within the creek at an elevation of 106 to $108 \mathrm{~m}$. This indicates that the Pomona interflow zone is the likely candidate for controlling the base groundwater level in nearby wells. Additionally, the groundwater level in the nearby Lolo well, WASC 2767, is below the elevation of the interflow zone exposure even at the height of annual recovery, which reinforces the determination that the Pomona aquifer is controlling the base groundwater level. Note, this inflection point on hydrographs at $100 \mathrm{~m}$ is seen in lower watershed wells, and in stratigraphically lower aquifers (Rosalia, Sentinel Gap 
and Sand Hollow), indicating that the Pomona interflow zone exposure in Mosier Creek is controlling the head distribution in all of these units through wells interconnecting the lower aquifers with the Pomona aquifer, as Lite (2013) predicted.

Additional data were obtained through the OWRD for Well 2760. This well, completed in the Pomona aquifer, is equipped with a pressure transducer and datalogger that provides continuous groundwater elevation monitoring. A closer look at the groundwater level trend for well 2760, juxtaposed with the percent difference in streamflow from the upper gage to the lower gage across the interflow zones of the Pomona and Lolo flows, reveals a similar trend and timing between drawdown in the well and a transition between gaining to losing water to the groundwater system in the beginning of June 2013 (Figure 65). The stream then transitions back to a gaining stream when the Pomona groundwater level begins to recover. The drawdown and transition from a gaining to a losing stream can be seen each year since the lower streamflow gage was installed. This same relationship is shown for summer 2014 in Figure 66. This is the same conclusion derived by Lite and LaMarche (2014).

In addition to the larger scale transition from a gaining to a losing stream with drawdown in the Pomona interflow zone, there are also smaller scale similarities. For example, the slight recovery of groundwater in late June and early July coincides with less water from Mosier Creek being lost to the groundwater system at that time. Lite and LaMarche (2014) indicate this is likely due to 
decreased pumping for irrigation during cherry harvest. Although precipitation data was not examined in-depth for this study, the slight differences in the relationship described above, seen in Figure 66 during June and the streamflow difference spikes in October, are likely due to precipitation events.

As indicated by this data and Lite and LaMarche (2014), the close relationship between drawdown and transition in stream interaction indicates that the Pomona exposure in Mosier Creek is closely connecting the groundwater and surface water. So much so that drawdown of groundwater level likely causes Mosier Creek to transition from a stream that is gaining water from the groundwater system, to one that is losing water to the groundwater system. Given this close relationship, it is also likely that the Lolo/Pomona interflow zone exposed in Mosier Creek is defining the lower extent of groundwater levels in the Mosier area through interconnected wells when the groundwater system in in equilibrium. During overdraft conditions, the system would be expected to show increased groundwater declines with less annual recovery; this is likely what is shown in Figure 47 during 2015. Additionally, the apparent overdraft condition likely indicates there is dewatering and depressurization of the groundwater system. 


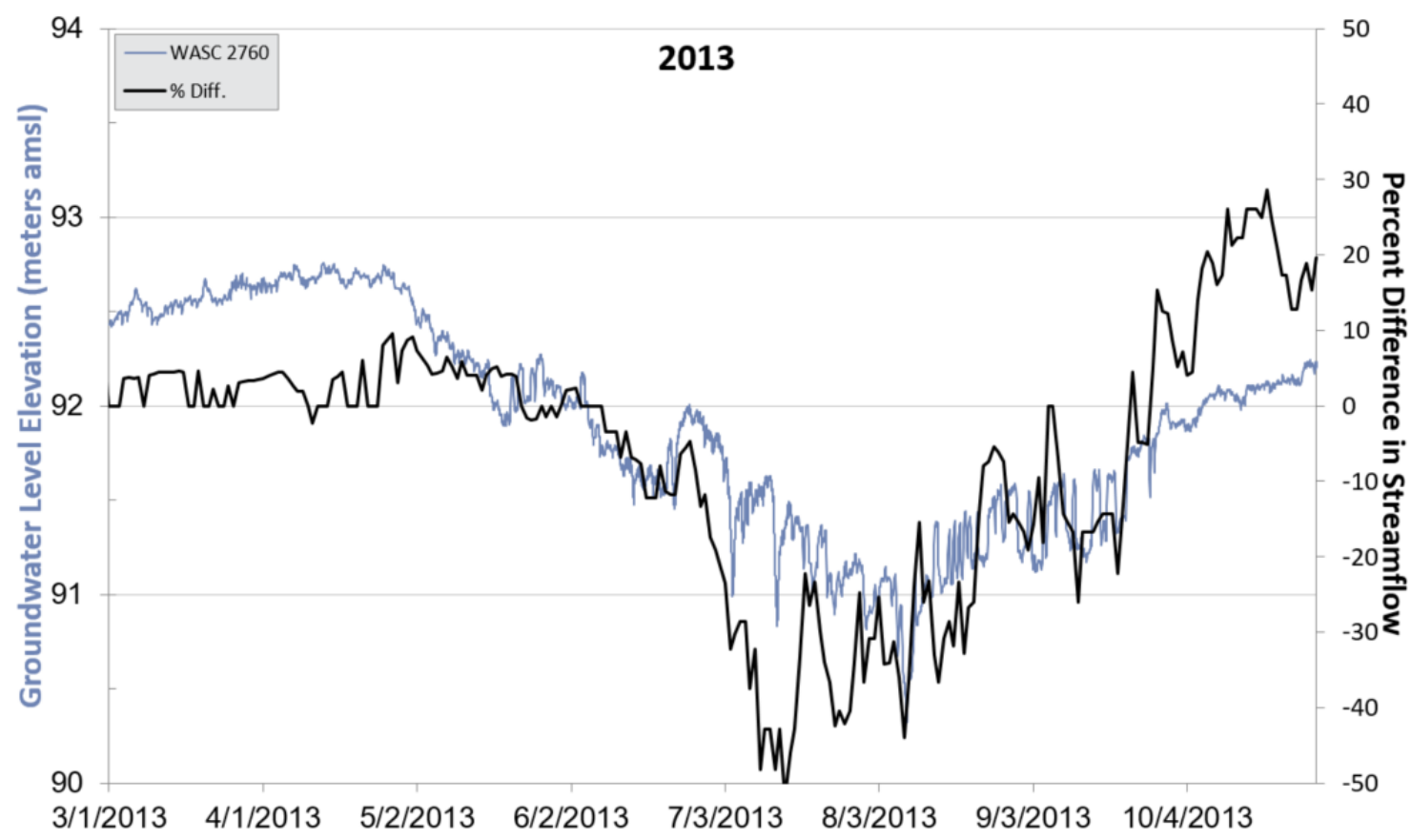

Figure 65: 2013 Water level trend for WASC 2760 (Pomona aquifer) plotted with the percent difference between upper streamflow gage and lower stream gage. The figure indicates the stream transitions from slightly gaining water from the groundwater system, to losing water to the groundwater system, which is coincident with drawdown in the well. These findings are consistent with those of Lite and LaMarche (2014).

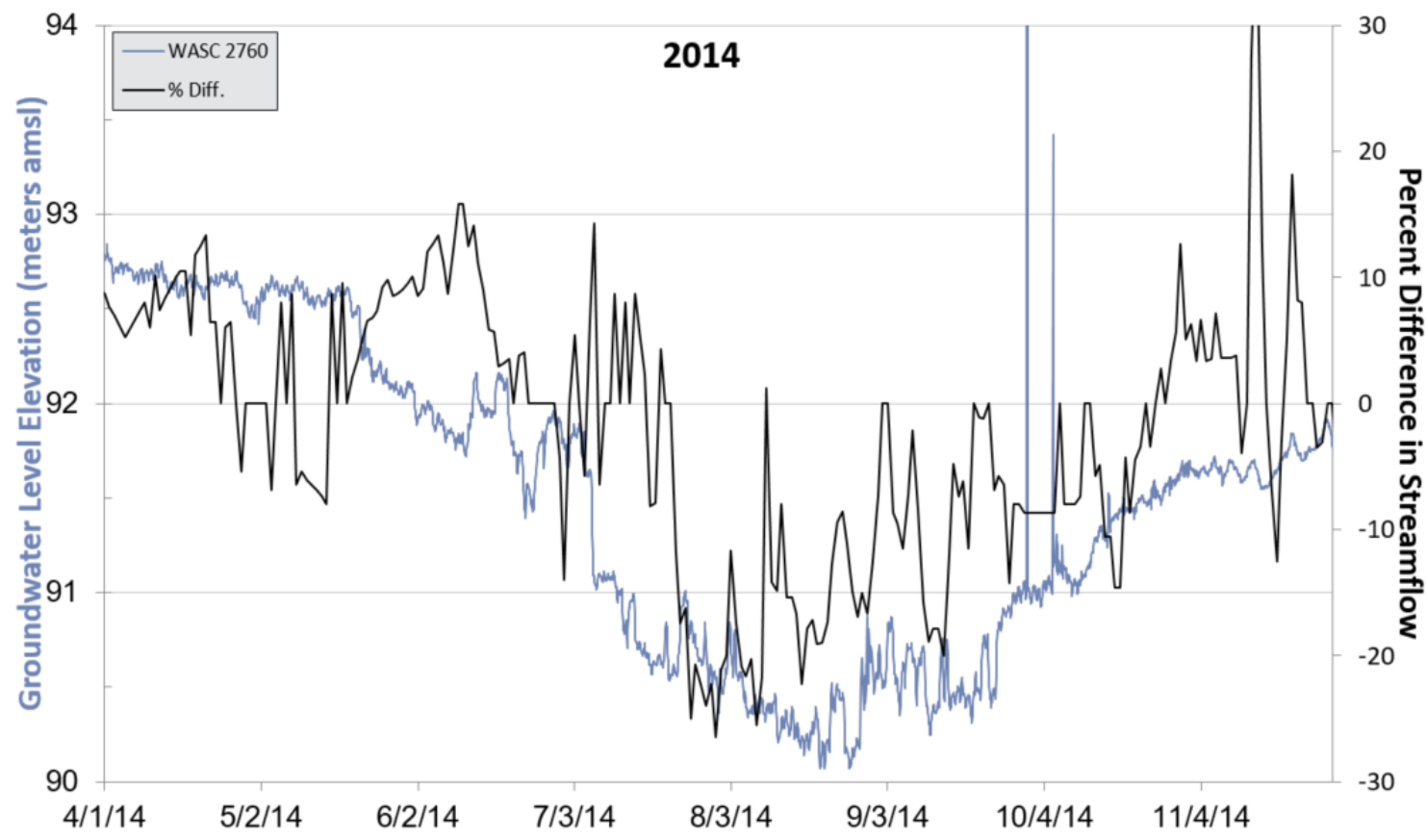

Figure 66: 2014 Water level trend for WASC 2760 (Pomona aquifer) plotted with the percent difference between upper streamflow gage and lower stream gage. The figure indicates the stream transitions from slightly gaining water from the groundwater system, to losing water to the groundwater system, which is coincident with drawdown in the well. These findings are consistent with those of Lite and LaMarche (2014). 


\section{Chemical Hydrogeology}

The physical hydrogeology indicates a highly connected groundwater surface water system with stream water being lost to the groundwater system during peak drawdown in summer time. It should be noted that stream samples were only collected in the second sampling campaign so any changes in stream composition between early to late summer/fall cannot be determined from this study. Furthermore, any surface water delivered to the groundwater system via exposures in Mosier Creek will be dispersed in the groundwater and a lag time would be expected before a signal could be seen in well waters. The infiltration of molecules of water through the streambed and into the groundwater system is suspected to take place at a much slower rate that the gains/losses that occur in the streambed as a pressure response.

The attempt to differentiate geochemical facies associated between aquifers revealed interesting trends in the hydrochemical data. Although clear and definitive facies were not seen in the cation ratio plots to differentiate individual aquifers, a pronounced linear trend and specific groupings were identified differentiating waters from upper and lower watershed wells. As described previously in the results section, the linear trend and groupings are most readily apparent in the plots of fluoride, sodium, potassium, and magnesium, vs cation ratio in Figure 58 through Figure 61. The groupings are also apparent in the $\mathrm{pH}$ versus specific conductance plots (Figure 63). 
There are two explanations for the linear trends and groupings of higher versus lower watershed wells. The first is that with increased distance of travel and, hence, residence times, a more evolved chemical signature is imparted on the waters. This explanation likely plays a role in the observed differences between upper and lower watershed wells but is not suspected to explain the trends entirely because the distance from the uppermost wells to the lower wells is at most $3.8 \mathrm{~km}$. The second interpretation is that the location of each well relative to major structural features, primarily the Mosier syncline and the Columbia Hills anticline, controls the amount of local versus regional recharge. The wells located higher up on the flank of the Columbia Hills anticline likely receive more locally recharged waters with a less evolved chemical signature, whereas the lower watershed wells receive deeper, regional flow, resulting in a more chemically evolved signature. This idea will be discussed further in the following paragraphs, as well as the pronounced commingled signature apparent within the data.

It stands to reason that wells located higher up the northwest flank of the Columbia Hills anticline would receive waters recharged predominantly from local precipitation where interflow zones are exposed. In contrast, lower watershed wells located closer to the axis of the Mosier syncline and the Rocky Prairie thrust, could conceivably receive regional, more chemically evolved waters as groundwater flow is funneled down the synclinal axis until intercepting the low flow boundary of the Rocky Prairie thrust fault. In the simplest terms, the lower watershed wells have 
lower aquifer elevations, thus a more likely flow path of waters infiltrating through Cascadian deposits upslope of the local watershed, via gravity.

Other structural features which could possibly contribute regional recharge to the Mosier area, although not yet studied in depth with regard to permeability and head gradient, are the Maupin Wrench fault and the Chenoweth Thrust fault. The Maupin Wrench fault possibly provides a pathway for regional flow, as it juxtaposes Rosalia with Grand Ronde basalts less than $1.5 \mathrm{~km}$ south of the sample location of MRCR1 (personal communication with Jason McClaughry, Eastern Oregon Regional Geologist, Oregon Dept. of Geology and Mineral Industries, May 18, 2016). The Chenoweth Thrust fault could possibly provide a pathway for regional flow to the Mosier area as it was suspected by Burns et al. (2012) to act as a flow boundary, which could cause upward flow from lower to upper aquifers, and contributions to Mosier Creek. Although further investigation of these structural features was not part of this project, their influences possibly provide alternate or additional explanations for the chemical hydrogeology results of this study. The major structural features were shown in Figure 7.

The effects of increased regional recharge, and hence, more evolved aquifer waters seen in lower watershed wells, is best shown in the fluoride vs cation ratio plot in Figure 58. The groupings of lower watershed and upper watershed wells is clearly evident, as shown in Figure 67. Within the grouping of upper watershed wells, are the stream and spring samples, which reinforces the determination that these wells are more closely tied to local recharge. The most chemically evolved 
waters were from WASC 50250 and WASC 2767. This is thought to be the direct result of a more regional recharge signal, but up gradient from the commingling that occurs lower in the watershed. Commingling is thought to be the likely cause of the grouping of WASC 2759, 2765 (only sampled in sampling campaign 1), 50012, 51497, and 51778.

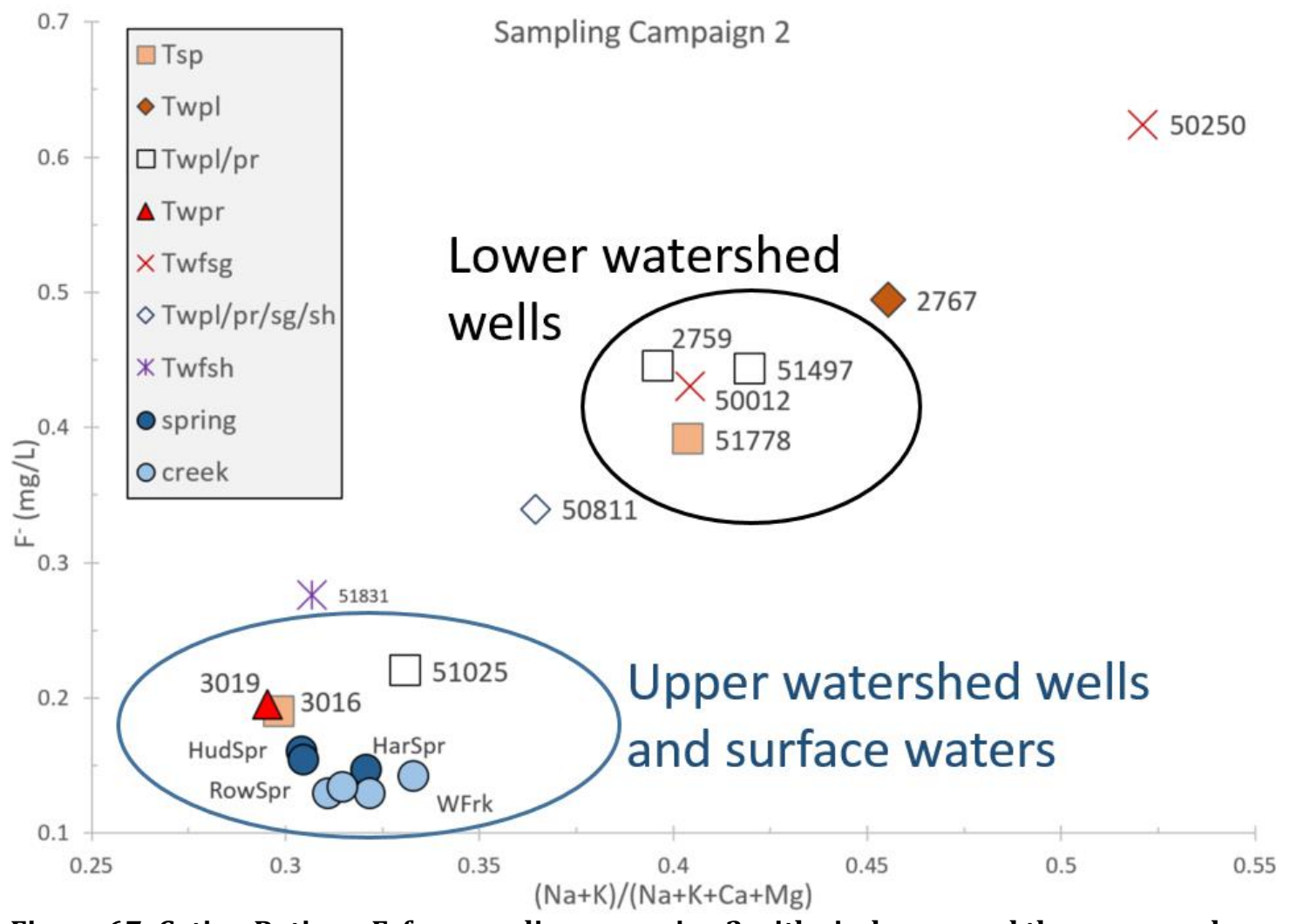

Figure 67: Cation Ratio vs $F^{-}$for sampling campaign 2 with circles around the upper and lower watershed well groupings. The lower watershed wells consist of the suspected highly commingled well grouping, while the higher cation ratio of WASC 2767 and 50250 is thought to be the result of the wells being located up-gradient from the commingling.

The magnesium plot also clearly displays a linear trend with groupings based on location (Figure 61). Lower magnesium concentrations and increased cation ratio is thought to be the signature of more evolved waters. Vlassopoulos et al. (2009) explained that initially there is an increase in calcium and magnesium 
through the dissolution of basaltic glass, pyroxene, and plagioclase, in less evolved waters, but with increased residence times supersaturation leads to the precipitation of clays, zeolites, and calcites, which subsequently removes calcium and magnesium resulting in the lower values of these elements in evolved CRBG groundwaters. The upper watershed wells, those with less evolved signatures, plot off of the linear trend, along with surface water and spring samples. One exception in the second sampling campaign is WASC 51831. This is a Sand Hollow well that exhibits the highest magnesium concentrations. In contrast to this being the stratigraphically lowest aquifer, these waters are the least evolved endmember in the linear trend. Bulk chemistry data for the Sand Hollow flow from this same well reveals that the magnesium oxide concentrations are not significantly higher than other flows, and considerably lower than the Pomona flow (Appendix A, WASC 51831, sample depths 208, 227, and $269 \mathrm{~m}$ ). Thus, the high magnesium concentration is not thought to be the result of the bulk chemistry of the Sand Hollow flow, but an indication of less evolved waters and a more local flow path. As mentioned previously, a pronounced commingled signature is also seen in the data. One indication of this is the different cation ratios for the wells sampled from the Sentinel Gap aquifer (WASC 50250 and 50012). Well 50250 has the highest cation ratio value while 50012 has a lesser cation ratio value, which falls in the middle of the lower watershed grouping (Figure 67). That grouping contains three wells interconnecting Lolo/Rosalia aquifers, one Pomona well, and one Lolo well. A likely explanation for this phenomenon is the high degree of commingling that 
occurs in the lower Mosier watershed. Burns et al. (2012) estimated that 15 to 30 $\mathrm{m}^{3} / \mathrm{hr}$ (70 and $\left.135 \mathrm{gpm}\right)$, equivalent to $11-22$ percent of total annual pumping in 2006, was commingled from lower to upper aquifers in WASCO 2765 (City Well \#3). Burns et al. (2012) only documented upward flow and not downward flow in the well; thus, this may not provide the best explanation for how commingling could have occurred from downward flow (Priest Rapids to stratigraphically lower Sentinel Gap). A closer inspection of the well hydrographs (Figure 68) reveals that the hydraulic head in the Sentinel Gap well, 50012, was consistently lower than the hydraulic head in the Priest Rapids Lolo/Rosalia wells (2758 and 2795) by 1 to 2 meters from 2004 to 2014. Although WASC 50012 is not likely commingling, the lower hydraulic head could cause downward flow in nearby wells connecting Priest Rapids and Sentinel Gap aquifers, especially during drawdown from this irrigation well. Indeed, in all cation ratio plots, and especially Figure 63, WASC 50012 plots in tight grouping with the lower watershed Lolo/Rosalia wells (WASC 2759, 2765, and 51497). Another possible explanation for the tight grouping of these wells is that there is a leaky seal in WASC 50012 interconnecting these aquifers, which isn't unlikely owing to the inherent difficulty of placing a seal when the well is under pressure (personal communication with Ken Lite, Oregon Water Resources Department, July 6, 2016). 


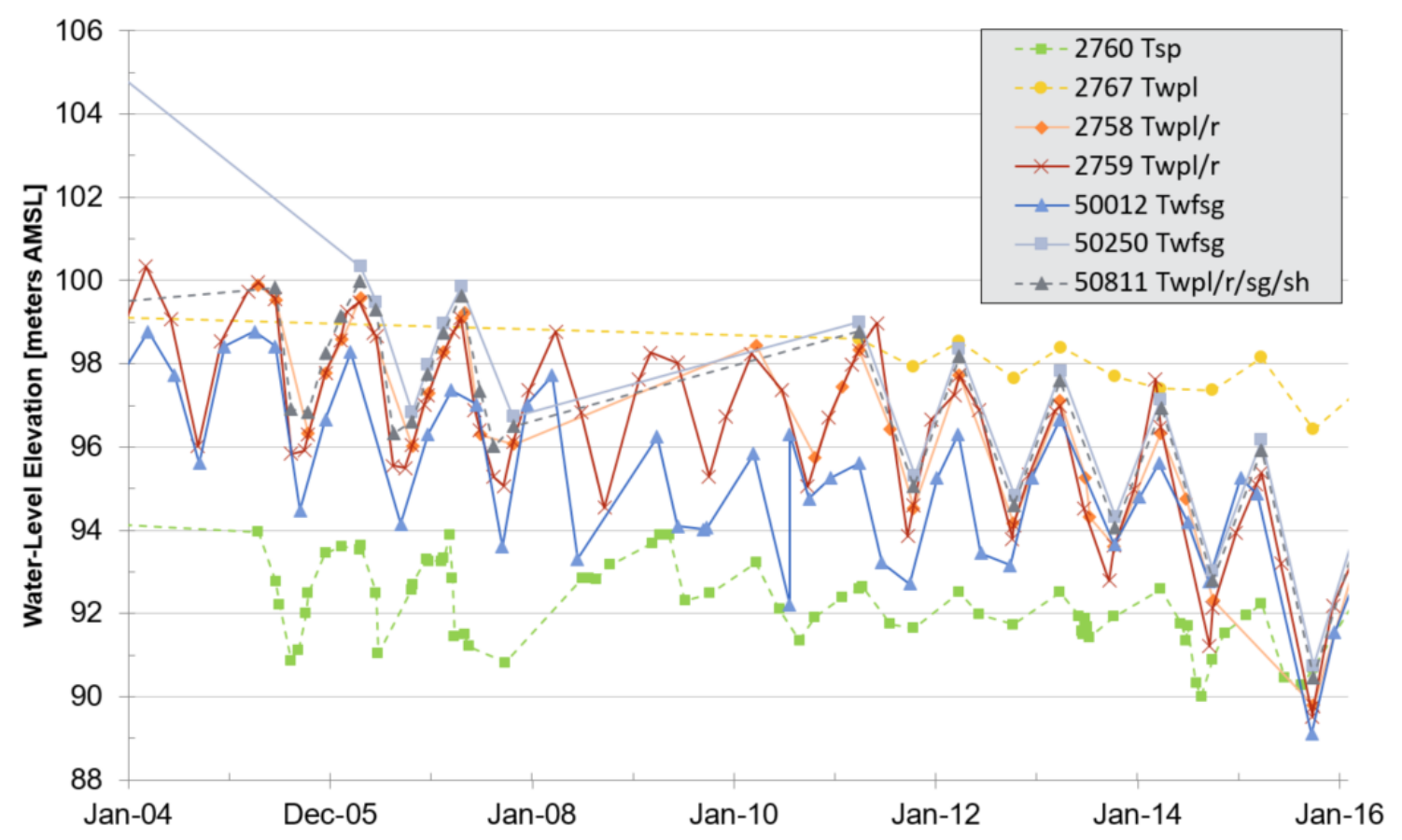

Figure 68: Hydrographs for seven wells within the OWRD Administrative Area, displaying the groundwater levels from 2004 through 2016. WASC 50012 has a lower head than Lolo/Rosalia commingled wells from 2004 through late 2012. Domestic wells are displayed with dashed lines and irrigation wells have solid lines. The interflow zone(s) of each well are displayed in the legend. Refer to Table 3 for well construction details. Tsp: Pomona, Twpl: Lolo, Twpr: Rosalia, Twfsg: Sentinel Gap, Twfsh: Sand Hollow.

Another indication that lower watershed wells display a mixed signature between shallow and deep aquifers is the fact that WASC 2767 plots with a more evolved cation ratio than all the lower watershed wells. WASC 2767 is completed into the Lolo aquifer and is located in the middle of the study area, up-gradient from the lower watershed wells. The commingled signature for lower watershed wells is likely the reason why these lower watershed wells, completed in stratigraphically lower aquifers, do not display a more evolved cation signature than the Lolo aquifer in 2767.

Another possible effect of commingling is seen in the cation ratio contrast between the two Pomona wells, WASC 3016 and 51778. WASC 3016 is higher in the 
watershed and 51778 is in the lower watershed. The large degree of commingling that takes place lower in the watershed has likely given the Pomona waters in 51778 a more evolved signature, when compared to 3016 . An alternate explanation would simply be that the lower watershed Pomona well (51778), closer to the Mosier syncline and with a lower aquifer elevation, has a more regional flow path where the origin of recharge is waters infiltrating through Cascadian deposits upslope of the local watershed, resulting in the more evolved chemical signature.

\section{Cluster Analysis and Principal Components Analysis}

To further investigate the determinations made from the hydrochemical data and plots presented in the results section, cluster analysis and principal component analysis was utilized for the data set. Hierarchical cluster analysis (HCA) is a statistical tool to classify objects into categories based on their degree of similarity. Principal component analysis (PCA) is a technique to reveal the internal structure of a multivariate data set where as much variability within the data is accounted for in the first few principle components (Vlassopoulos et al., 2009). Together, these methods provided a statistical means to group the hydrochemical data into distinct populations.

The results of HCA and PCA are provided in Figure 69. These statistical analyses largely serve to strengthen the determinations made previously. Cluster analysis revealed three groupings, consisting of upper watershed wells (blue outline), surface waters and springs (green outline), and the lower watershed wells (red outline). The only exceptions were the August spring sample of HarSpr being 
grouped with the upper watershed wells, and WASC 51831 and 50811 being clustered primarily with lower watershed wells.

The first two principal components account for $59.82 \%$ of the variance. Figure 69 reveals that upper watershed wells plot close to surface waters and springs. The Sentinel Gap aquifer waters of WASC 50250 were distinguished as it plots away from the other wells, and WASC 50012 plots in a grouping with lower watershed wells commingling Lolo and Rosalia. Note that to simplify the data, WASC 50811 has a symbol the same as Lolo/Rosalia commingled wells, but this well is open to Lolo, Rosalia, Sentinel Gap, and Sand Hollow units.

Observations (axes D1 and D2: $59.82 \%$ ) after Varimax rotation

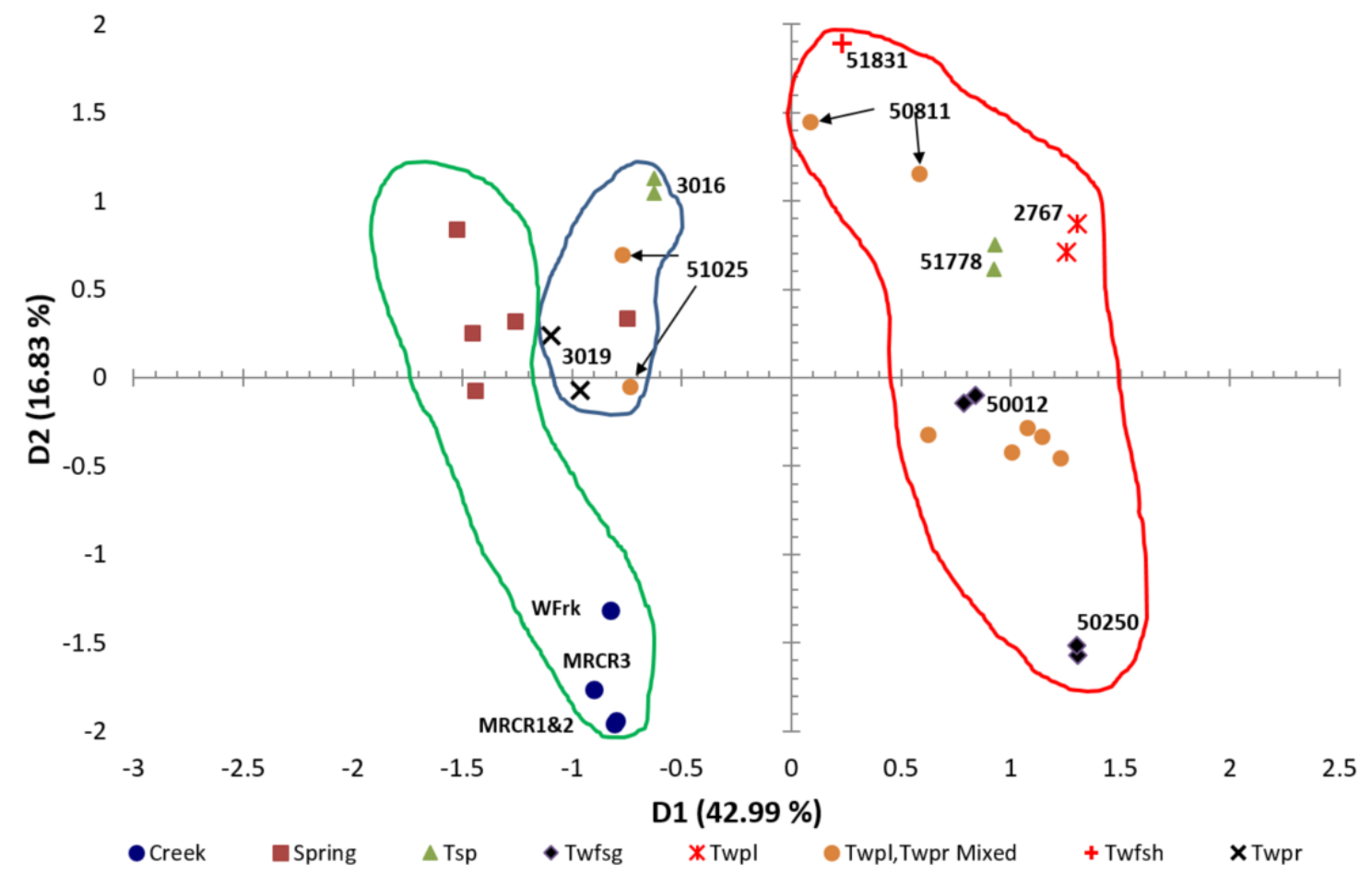

Figure 69: Biplot of principal components 1 and 2 with symbols representing each well's representative aquifer(s). The red, blue, and green groupings are the groupings from cluster analyses. 


\section{Stable Isotopes}

Aside from the delineation of aquifer waters discussed below, there was a possible clue from isotopic data with regard specifically to groundwater - surface water interactions. Of the two stream samples, MRCR3 is lighter, or more negative, with regard to $\delta^{18} 0$ than $W F R K$, indicating that the lighter signature of MRCR3 could be a result of groundwater contributions to the stream. The samples were collected on October 12, 2012, which was a few days after the stream began to gain water from the groundwater system. The location of $M R C R 3$ is downstream of the Pomona/Lolo interflow zones; thus, the more negative signature would be expected from the addition of groundwater. Uncertainty exists in this interpretation because WFRK was collected from West Fork Mosier Creek before its confluence with Mosier Creek. A clearer determination could be drawn from isotopic data from Mosier Creek upstream of the Pomona/Lolo interflow zone.

One consistency throughout the hydrochemical plots was the differentiation of WASCO 50250 as the sample with the most evolved chemical signature. The stable isotope data presented in Figure 64 reinforces this determination. WASCO 50250 is the most depleted well sample, followed by 50012. Both wells are completed in the Sentinel Gap aquifer. The only well sampled that is completed in a stratigraphically lower aquifer is WASCO 51831, which is completed in the Sand Hollow. Interestingly, WASCO 51831 is not as depleted as the two Sentinel Gap wells. These findings seem to support the interpretation discussed above, that wells/aquifers located higher up the Columbia Hills anticline receive a larger 
proportion of local recharge. It is worth mentioning again that WASC 51831 was sampled from a cistern so there are additional uncertainties regarding whether the results are truly representative of unaltered aquifer waters.

Wells 51497 and 51778 are the next most enriched samples, followed by the spring and surface water samples. The isotopic signatures of 51497 and 51778 could also be interpreted to strengthen the inferences made toward the commingling signature seen in lower Mosier watershed wells. Both of these wells are located in lower Mosier watershed, one is interconnecting Lolo and Rosalia aquifers and the other is a Pomona well, yet they plot in close proximity to one another on the stable isotope plot. This is most likely due to the high degree of commingling.

Larson (2000) explains that a depleted signature in groundwater is the result of one of three things: (1) seasonality of recharge, (2) precipitation originating from a higher altitude, and/or (3) precipitation recharged under a different climate or time period. In central Columbia Plateau CRBG aquifer studies, where it has been determined lower Grande Ronde aquifers likely contain waters dating back to the Pleistocene, the depletion values for $\delta^{18} 0$ range from - 15.4 to $-17.5 \%$ (Carey, 2011; Larson, 2000; Newcomb, 1972; and Crosby and Chatters, 1965). The Frenchman Springs aquifer waters are not nearly as depleted as the Grand Ronde samples so it is not likely that these depletion values represent a long residence time. Carey (2011) revealed a relationship between $\delta^{18} 0$ and ${ }^{14} \mathrm{C}$ apparent age (Figure 70). This data indicates that even the most negative $\delta^{18} 0$ values from the Mosier area are at 
most tens to hundreds of years in apparent age, as opposed to thousands of years in apparent age as seen in lower aquifers of the central Columbia Plateau.

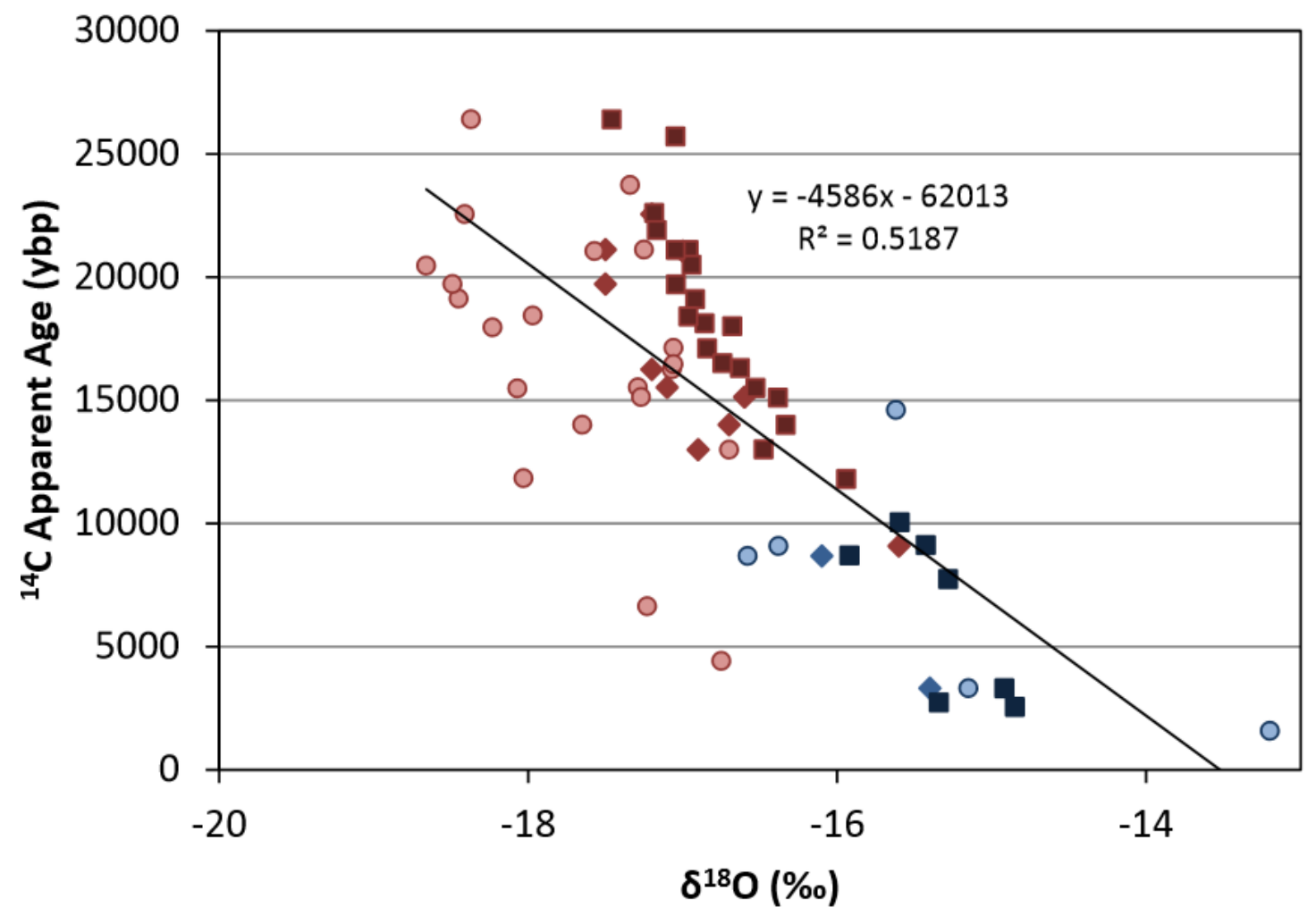

Figure 70: $\delta^{18} \mathrm{O}$ as a function of ${ }^{14} \mathrm{C}$ apparent age from Carey (2011). Lower aquifer waters are red and upper aquifers are blue, showing recharge from the Pleistocene in lower aquifers. Referencing my $\delta^{18} \mathbf{O}$ values with this data indicates all the Mosier area wells likely contain modern recharge on the order of tens to hundreds of years at most, as opposed to thousands of years.

This leaves either seasonality of recharge or higher altitude precipitation as the cause of the depleted signatures. However, the seasonality of the isotopic signature is generally thought to be "smoothed out" as it infiltrates into the subsurface (Clark, 2015) and the local topographic relief is quite substantial, so variation in recharge elevations is then the most likely explanation.

In the absence of stable isotope sampling of precipitation in winter and summer for the Mosier area, it is not possible to develop a local meteoric water line 
(LMWL). However, a LMWL has been derived for the central Cascades and northward to Mt. Hood. These studies, completed by Ingebritsen et al. (1988), James (1999), and Nathenson (2004), were included in Figure 64 as a way to explore the possibility that some of the precipitation which recharges the Mosier area Frenchman Springs aquifers originated from a higher elevation.

The LMWL from James (1999) and Ingebritsen et al.'s (1988) data east of the Cascades plots very near the well samples from the Moser area. Given this and the equivalent longitudes $\left(\sim 121^{\circ} 35^{\prime} \mathrm{W} \pm 15^{\prime}\right)$ of Mosier and the east flank of the Cascades where their samples were obtained, it is reasonable to at least qualitatively utilize James' (1999) linear relationship between elevation and $\delta^{18} 0$ in precipitation samples from the central Oregon Cascades. Although the specific elevations attained are not likely accurate because James' (1999) model is based off of data from the central Cascades, the general relationship is applicable. The relationship is given by the equation: $\delta^{18} \mathrm{O}=-0.0018$ (elevation in $\mathrm{m}$ ) -10.9 . To investigate this relationship as it relates to the stable isotope data collected in this study, we apply this relationship in Figure 71. The elevation of each sample was plotted along with its $\delta^{18} \mathrm{O}$ value. Tracing a line horizontally to the linear regression, then down to the x-axis gives the inferred recharge elevation of James' (1999) data. The data are also presented in Table 10. 


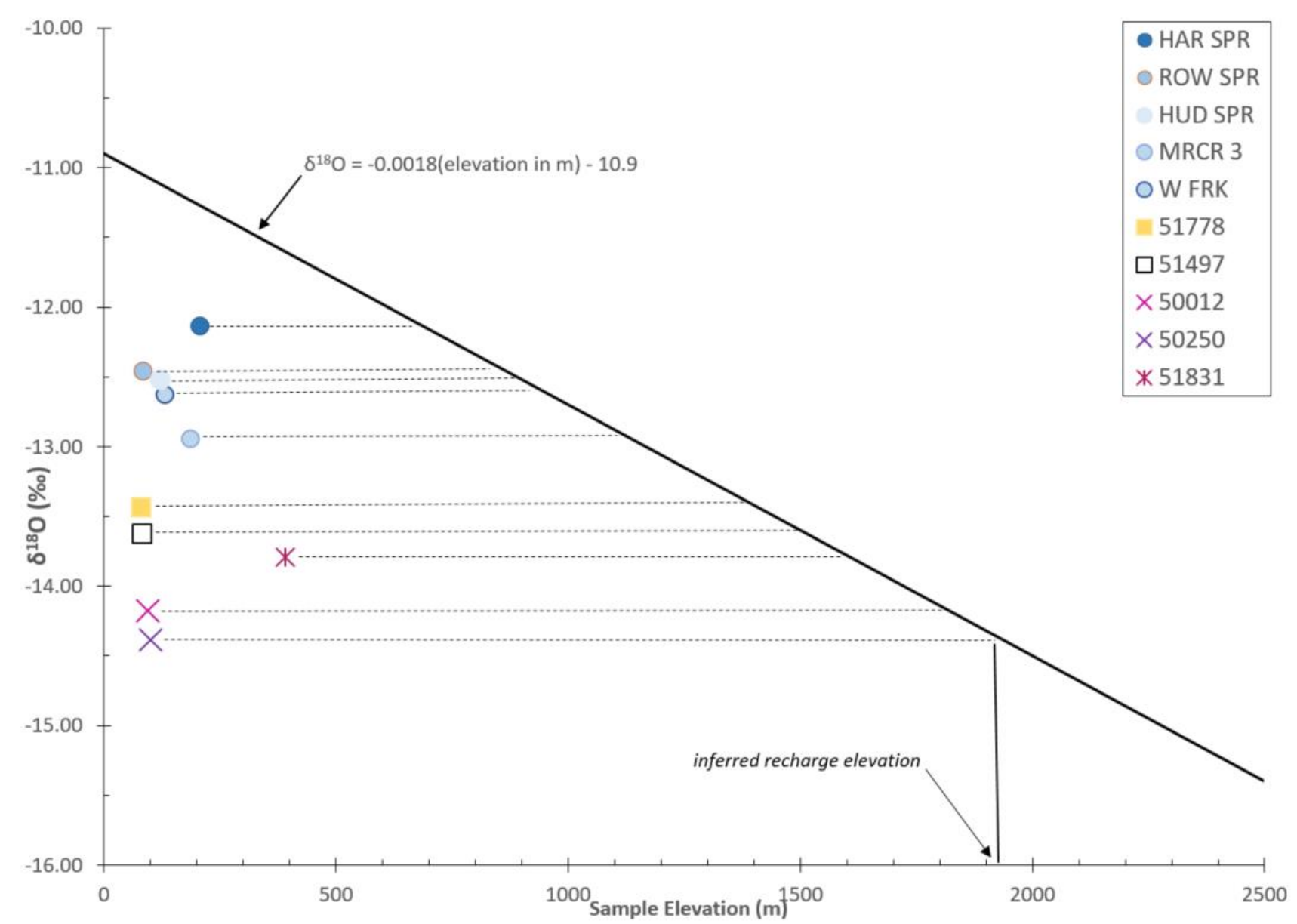

Figure 71: Inferred recharge elevation for samples from this study. The relationship between sample elevation of recharge as determined by James (1999) from snow core samples in the Central Cascades. The approximate recharge elevation is estimated by tracing a line to the linear regression, and then another line down to the elevation, inferred to be the elevation where precipitation is comparable. 
Table 10: Inferred recharge elevation from James' (1999) linear regression relationship between $\delta^{18} \mathbf{0}$ values from precipitation in the central Cascades.

\begin{tabular}{cccc}
\hline \hline Sample/Site & $\delta^{18} \mathrm{O}(\%)$ & Elevation $(\mathrm{m})$ & $\begin{array}{c}\text { Inferred } \\
\text { Recharge } \\
\text { Elevation }(\mathrm{m})\end{array}$ \\
\hline \hline HAR SPR & -12.14 & 206 & 687 \\
HUD SPR & -12.52 & 120 & 898 \\
ROW SPR & -12.46 & 85 & 867 \\
MRCR 3 & -12.94 & 185 & 1135 \\
W FRK & -12.62 & 130 & 958 \\
WASC 50012 & -14.18 & 94 & 1822 \\
WASC 51497 & -13.62 & 81 & 1513 \\
WASC 51778 & -13.44 & 80 & 1409 \\
WASC 51831 & -13.79 & 389 & 1608 \\
WASC 50250 & -14.38 & 100 & 1936 \\
\hline
\end{tabular}

Much of the recharge in the upper aquifers of Mosier Creek is thought to originate on the flanks of Wasco Butte and the Columbia Hills anticline, approximately $714 \mathrm{~m}$ (Lite and Grondin, 1988). The highest overall elevation within the entire watershed is approximately 1,220 $\mathrm{m}$ in the headwaters of Mosier Creek to the south. All stream and spring samples shown in Figure 71 and Table 10 have inferred recharge elevations of under 1,000 meters. This suggests (assuming James' (1999) regression is applicable to the Mosier area) that all springs and streams are likely recharged from within the watershed. However, all well samples have inferred recharge elevations of over $1,220 \mathrm{~m}$, suggesting all well waters have at least some component of recharge which originated at elevations above those of the immediate Mosier Creek watershed.

It is worth repeating that although the specific elevations given by James' (1999) regression are likely not correct, because the model is derived from data in the central Cascades, the general relationship of relatively more negative $\delta^{18} 0$ 
values with increased elevation of recharge holds true. For example, WASCO 51778, a Pomona well, has an inferred recharge elevation above the local watershed. Initially, this recharge elevation seems unlikely as the Pomona flow pinches out on the flanks of the Columbia Hills anticline. Therefore, one would suspect that the majority of recharge for the Pomona aquifer is along the flanks of the Columbia Hills anticline and where the interflow zone is exposed along streams. However, the isotope data suggests that at least some component of recharge originates from higher elevations. The possible explanations for this are commingled wells delivering deeper aquifer waters to the Pomona aquifer, or water infiltrating through younger Cascadian units upslope from the local watershed. The second interpretation would indicate a regional flow path of recharge to the Pomona aquifer.

WASC 51831, a Sand Hollow well, also has an inferred recharge elevation upslope of the local watershed indicating a more regional recharge mechanism. This does not seem to correlate well with the cation ratio plots provided earlier, because 51831 plots closer to Mosier area streams, as opposed to the more evolved signature of the Sentinel Gap wells (for example: Figure 58). A possible explanation for this occurrence, and the fact that the stratigraphically deeper Sand Hollow aquifer displays a less evolved and less depleted hydrochemical signature when compared to the Sentinel Gap aquifer, is that the Sand Hollow aquifer in the Mosier area may receive more local recharge along the flanks of the Columbia Hills anticline than the Sentinel Gap aquifer. Additionally, WASC 51831 (a Sand Hollow well 
located higher up on the Columbia Hills anticline) has a greater aquifer elevation (over $120 \mathrm{~m}$ higher elevation) when compared to the lower aquifer elevations of WASC 50250 and 50012 (middle and lower watershed Sentinel Gap wells). Therefore, it stands to reason that the lower watershed wells receive more regional recharge via infiltration through Cascadian deposits upslope from the local watershed.

One possible clue regarding the phenomenon of Sentinel Gap waters being more evolved than Sand Hollow, was the discovery from subsurface geologic mapping (Chapter 2), that WASCO 51831 did not contain the Sentinel Gap flow as determined by XRF analysis of well cuttings. Considering the well's relatively high elevation and location further east and higher up on the flanks of the Columbia Hills anticline, perhaps this indicates the Sentinel Gap flow pinches out before any substantial outcrops occur, reducing the opportunity for recharge from local precipitation.

An investigation into the recharge elevation of the most isotopically depleted samples of the Sentinel Gap aquifer, WASC 50250 and 50012, reveals the greatest inferred recharge elevation located well outside of the local watershed. Frenchman Springs units do outcrop south of the Mosier watershed and along the Hood River Fault zone to the east so there are conceivable opportunities for recharge of these units at these higher elevations. Again, this data supports the interpretation that recharge occurs through younger Cascadian deposits upslope from the local 
watershed through a relatively more regional flowpath than was seen in upper watershed wells.

Uncertainties exist with the above interpretations due to the absence of isotope data from local precipitation. Temporal sampling of local precipitation would serve to further differentiate local vs regional recharge for this study area. Additional uncertainty exists due to the less depleted signature from the Sand Hollow waters. However, the idea that wells tapping into aquifers further east and higher on the Columbia Hills anticline likely receive more local recharge, and vice versa, have limited flow path opportunities for regional recharge, seems to be a plausible and a likely explanation. Detailed mapping of the Frenchman Springs Member flows up the flanks of the Columbia Hills anticline would serve to resolve these uncertainties. Uncertainties notwithstanding, the isotopic data supports the interpretation that at least a portion of recharge originates as precipitation from high elevations outside of the local Mosier watershed along a more regional flowpath, especially for the lower aquifers in the Mosier area. 


\section{Chapter 4- Summary and Conclusions}

This study set out to investigate the interaction between groundwater and surface water near Mosier, OR. Despite many previous investigations concerning the significant groundwater declines since the mid-1970s, an aspect of the groundwater system yet to be studied in depth is how CRBG interflow zone exposures in Mosier Creek may be controlling groundwater elevations in the area. Methods used to investigate the interaction included: (1) detailed geologic mapping along area streams to identify interflow zones of individual CRBG flows, (2) analysis of stream discharge data and groundwater elevation data to characterize exchange of groundwater and surface waters, and (3) collection and analyses of 31 water samples from area wells, streams, and springs, to determine if waters from individual CRBG aquifers can be hydrochemically identified and to further constrain understanding of surface and groundwater interactions.

The location of the Pomona and Lolo interflow zones were identified in Mosier Creek and confirmed through XRF analysis. The general elevation of approximately $100 \mathrm{~m}$ for the Pomona interflow zone exposure was found to be coincident with an inflection point, or flattening of the decline trend beginning in 2004 , observed in well hydrographs. The inflection point was seen in lower aquifer wells, which indicates the groundwater decline in these wells is likely controlled by the interaction of the Pomona interflow zone in Mosier Creek, through wells that interconnect lower aquifers with the Pomona. 
Furthermore, the results of stream discharge data indicated a close connection between drawdown from irrigation and the transition seen in Mosier Creek from a gaining to a losing stream. During peak drawdown from 2012 to 2015, Mosier Creek lost anywhere from $20-40 \%$ of streamflow from the upper to lower gage. These findings, both the groundwater elevation as it relates to the Pomona interflow zone, and the transition of stream interaction with drawdown from irrigation, both serve to support Lite's (2013) and Lite and LaMarche's (2014) proposed mechanism of groundwater - surface water interaction and groundwater pumping impacts on Mosier Creek.

A limitation of the physical hydrogeology data stems from the stream discharge uncertainty involved with the upper USGS gage. However, the cyclic nature of stream gains/losses and transition that occurs at peak drawdown is deemed significant nonetheless.

Stable isotope and elemental chemistry data both revealed interesting findings toward the relative residence times of CRB aquifers, their sources of recharge, and a possible structural control on groundwater hydrochemistry. Both datasets revealed the Frenchmen Springs Sentinel Gap aquifer to contain the most depleted and most evolved waters in the study. Sentinel Gap samples were more depleted than other aquifer samples by 4.38 to $6.89 \%$ for $\delta \mathrm{D}$ and 0.39 to $0.59 \%$ for $\delta^{18} 0$. The most depleted sample was from WASC 50250, which is located in the middle reaches of Mosier Creek and up gradient from the primary location of 
commingling wells in the Mosier area. The samples from the lower watershed wells plot in a tight grouping, interpreted as the result of commingling.

The less evolved signature for waters from upper watershed wells exhibits the control of the Mosier syncline and the Columbia Hills anticline on recharge sources. The wells located higher up on the flank of the Columbia Hills anticline likely receive more local recharge, imparting a less evolved chemical signature, whereas the lower watershed wells receive more regional recharge, resulting in a more chemically evolved signature.

The isotope data and the qualitative application of James' (1999) inferred elevation of recharge regression indicates that precipitation from high elevations upslope from the local Mosier watershed is likely a source of at least a portion of recharge in lower aquifers. The data implies water is likely recharged through infiltration of younger Cascadian units along a more regional flowpath. However, these interpretations have limitations in that there is no local data for the development of a LMWL in the Mosier area for reference against the groundwaters of this study.

This research has shown that hydrochemical data can reveal discernable trends and signatures for CRB aquifers within a small watershed, and within individual flow units, as opposed to CRBG formations on a regional scale. The Mosier watershed would benefit from future research involving temporal variation isotopic data collection and analysis for local precipitation, streams, and aquifers. The temporal variation would likely provide a more definitive signature of mixing 
between wells and gains/losses to or from the groundwater system. The findings of this study are especially useful in that the system interaction is likely applicable to other watersheds similarly situated within the Yakima Fold Belt. The study results show that the understanding of local stratigraphy and its interaction with surface waters can have a substantial control on the groundwater system. 


\section{References Cited}

Anderson, J. L., and Vogt, B. F., 1987, Intracanyon flows of the Columbia River Basalt Group in the southwestern part of the Columbia Plateau and adjacent Cascade Range, Oregon and Washington, in Schuster, J. E., ed., Selected papers on the geology of Washington: Washington Division of Geology and Earth Resources Bulletin 77, p. 249-267.

Beeson, M.H. and Tolan, T.L., 1990, The Columbia River Basalt Group in the Cascade Range-A middle Miocene Reference Datum for structural analysis: Journal of Geophysical Research, v. 95, p. 19, p. 547-559, doi: 10.1029/JB095iB12p19547.

Beeson, M.H., and Tolan, T.L., 1996, Field trip guide to Columbia River Basalt intracanyon flows in western Oregon and Washington-Ginkgo, Rosalia, and Pomona flows: Portland, Oregon, Cordilleran Section meeting, Geological Society of America, $35 \mathrm{p}$.

Beeson, M.H., Fecht, K.R., Reidel, S.P., and Tolan, T.L., 1985, Correlations within the Frenchman Springs Member of the Columbia River Basalt Group: New insights into the middle Miocene tectonics of Northwest Oregon: Oregon Geology, v. 47, p. 87-96.

Beeson, M.H., Tolan, T.L. and Anderson, J.L., 1989, The Columbia River Basalt Group in western Oregon: Geologic structures and other factors that controlled flow emplacement and patterns, in Reidel, S.P., and Hooper, P.R., eds., Volcanism and tectonism in the Columbia River Flood Basalt Province: Geological Society of America Special Paper 239, p. 223-246.

Burns, E.R., Morgan, D.S., Lee, K.K., Haynes, J.V., and Conlon, T.D., 2012, Evaluation of Long-Term Water-Level Declines in Basalt Aquifers near Mosier, Oregon: U.S. Geological Survey Scientific Investigations Report 2012-5002, 134 p., GIS files. http://pubs.usgs.gov/sir/2012/5002/.

Carey, L.R., 2011, Evaluation of Oxygen and Hydrogen Isotopes in Groundwater of the Palouse Basin and Moscow Sub-Basin, M.S. Thesis, Washington State University, Pullman, Washington.

Clark, I., 2015, Groundwater Geochemistry and Isotopes, CRC Press, 422 p.

Clark, J.S. and Loop, S., 2002, Mosier Watershed Assessment: Wasco County Soil and Conservation District, p. 1-46.

Craig, H., 1961, Isotopic variations in meteoric waters: Science, v. 133, p. 1702-1703.

Crosby III, J.W., and Chatters, R.M., 1965, Water Dating Techniques as Applied to the Pullman-Moscow Ground-Water Basin, Washington State University, College of Engineering, Bulletin. 
Hooper, P.R., 2000, Chemical discrimination of Columbia River basalt flows, Geochem. Geophys. Geosyst., 1, 1024, doi:10.1029/2000GC000040.

Ingebritsen, S.E., Mariner, R.H., Cassidy, D.E., Shepherd, L.D., Presser, T.S., Pringle, M.K.W., and White, L.D., 1988, Heat-flow and water-chemistry data from the Cascade Range and adjacent areas in North-Central Oregon: U.S. Geological Survey Open-File Report 88-702, 205 p.

James, E.R., 1999. Isotope tracers and regional-scale groundwater flow: application to the Oregon Cascades. MS thesis. University of Oregon, Eugene, $150 \mathrm{p}$.

Jervey, G.M., 1996, Transition lands study area groundwater evaluation, Wasco County, Oregon: Mosier, Oreg., Jervey Geological Consulting.

Johnson, D. M., Hooper, P. R., Conrey, R. M., 1999, XRF analysis of rocks and minerals for major and trace elements on a single low dilution Li-tetraborate fused bead: Advances in XRay Analysis, v. 41, p. 843-867.

Kienle, C.F., 1995, Hydrogeologic investigation transition lands study area: Report prepared for Wasco County Planning and Economic Development Office, Wasco County, Oregon, Northwest Geological Services, Inc., 49 p. plus appendixes.

Larson, K.R., Keller, C.K., Larson, P.B., and Allen-King, R.M., 2000, Water Resource Implications in a Basalt Aquifer System, GROUND WATER, Vol. 38, No. 6, pages 947-953.

Lite, K.E. and Grondin, G.H., 1988, Hydrogeology of the basalt aquifers near Mosier, Oregon-A ground water resources assessment: Oregon Department of Water Resources Ground Water Report, no. 33, 119 p.

Lite, K.E., Jr., 2013, The influence of depositional environment and landscape evolution on groundwater flow in Columbia River Basalt-Examples from Mosier, Oregon, in Reidel, S.P., Camp, V.E., Ross, M.E., Wolff, J.A., Martin, B.S., Tolan, T.L., and Wells, R.E., eds., The Columbia River Flood Basalt Province: Geological Society of America Special Paper 497, p. 429-440, doi:10.1130/2013. 2497(17).

Lite, K.E. and LaMarche, J.L., 2014, Investigating Groundwater/Surface Water Interaction in Columbia River Flood-Basalt near Mosier, Oregon, GSA Annual Meeting Presentation, Paper No. 195-11.

McClaughry, J.D., Wiley, T.J., Conrey, R.M., Jones, C.B., and Lite, K.E., 2012, Detailed Geologic Map of the Hood River Valley, Hood River and Wasco Counties, Oregon: Open File Report 0-12-03, Oregon Department of Geology and Mineral Industries, $142 \mathrm{p}$. 
McKee, E. H., Swanson, D. A., and Wright, T. T., 1977, Duration and volume of Columbia River volcanism, Washington, Oregon, and Idaho [abs.]: Geological Society of America Abstracts with Programs, v. 9, no. 4, p. 463- 464.

Nathenson, M., 2004, Springs on and in the vicinity of Mount Hood volcano, Oregon, U.S. Geological Survey: Open-File Report 2004-1928, 43 p.

Newcomb, R. C., 1972, Quality of the groundwater in basalt of the Columbia River group, Washington, Oregon, and Idaho, U.S. Geological Survey Water-Supply Paper, 1999-N.

Newcomb, R.C., 1969, Effect of Tectonic Structure on the Occurrence of Ground Water in the Basalt of the Columbia River Group of The Dalles Area, Oregon and Washington: U.S. Geological Survey Professional Paper 383-C, 33 p.

Porcello, J., Tolan, T., Lindsey, L., 2009, Groundwater Level Declines in the Columbia River Basalt Group and their Relationship to Mechanisms for Groundwater Recharge: A Conceptual Groundwater System Model, Columbia Basin Ground Water Management Area of Adams, Franklin, Grant, and Lincoln Counties: Consultant report prepared for Columbia Basin GWMA, prepared by GSI Water Solutions, Inc., June 2009.

Reidel S.P., Tolan, T.L., and Beeson, M.H., 1994, Factors that influenced the eruptive and emplacement histories of flood-basalt flows of the Columbia River Basalt Group, in Swanson, D.A. and Haugerud, R.A., eds., Geologic Field Trips in the Pacific Northwest: Geological Society of America Annual Meeting Field Guide, p. 1B-1-1B-18.

Reidel, S.P., Martin, B.S., and Petcovic, H.L., 2003, The Columbia River flood basalts and the Yakima fold belt, in Swanson, T.W., ed., Western Cordillera and adjacent areas: Boulder, Colorado, Geological Society of America Field Guide 4, p. 87-105. For permission to copy, contact editing@geosociety.org. (C) 2003 Geological Society of America.

Reidel, S.P., 1984, The Saddle Mountains: The evolution of an anticline in the Yakima fold belt: American Journal of Science, v. 284, p. 942-978.

Reidel, S.P., 1998, Emplacement of Columbia River flood basalt: Journal of Geophysical Research, v. 103, p. 27,393-27,410, doi: 10.1029/97JB03671.

Reidel, S.P. and Tolan, T.L., 1992, Eruption and emplacement of flood basalt: An example from the large-volume Tepee Butte Member, Columbia River Basalt Group: Geological Society of America Bulletin, v. 104, p. 1650-1671, doi: 10.1130/0016-7606(1992)104<1650:EAEOFB>2.3.CO;2.

Reidel, S.P., Johnson, V.G., and Spane, F.A., 2002, Natural Gas Storage in Basalt Aquifers of the Columbia Basin, Pacific Northwest USA: A Guide to Site 
Characterization: Richland, Washington, Pacific Northwest Laboratory PNNL13962.

Schmincke, H. U., 1967, Fused tuff and pepperites in south-central Washington: Geological Society of America Bulletin, v. 78, p. 319-330.

Swanson, D.A., Anderson, J.L., Camp, V.E., Hooper, P.R., Taubeneck, W.H., and Wright, T.L., 1981, Reconnaissance Geologic Map of The Columbia River Basalt Group, Northern Oregon and Western Idaho: U.S. Geological Survey Open-File Report 81-797, 33 pp.

Swanson, D.A., Wright, T.L., Hooper, P.R., and Bentley, R.D., 1979, Revisions in stratigraphic nomenclature of the Columbia River Basalt Group: U.S. Geological Survey Bulletin 1457-G, 59 p.

Tolan, T.L., Campbell, N.P., and Lindsey, K.A., 2000, Exploring the hydrogeology of the Columbia River Basalt Group-A field guide to selected localities in the Columbia Plateau, Washington: Tacoma, Washington, Third Washington State Hydrogeology Symposium, October 14-15, 2000, 66 p.

Tolan, T.L., Martin, B.S., Reidel, S.P., Anderson, J.L., Lindsey, K.A., and Burt, W., 2009, An introduction to the stratigraphy, structural geology, and hydrogeology of the Columbia River Flood-Basalt Province: A primer for the GSA Columbia River Basalt Group field trips, in O'Connor, J.E., Dorsey, R.J., and Madin, I.P., eds., Volcanoes to Vinyards: Geological Field Trips through the dynamic landscape of the Pacific Northwest: Geological Society of America Field Guide 15, p. 599-643, doi: 10.1130/2009.fld015(28).

Tolan, T.L., Reidel, S.P., Beeson, M.H., Anderson, J.L., Fecht, K.R. and Swanson D.A., 1989, Revisions to the estimates of the areal extent and volume of the Columbia River Basalt Group, in Reidel, S.P., and Hooper, P.R., eds., Volcanism and Tectonism in the Columbia River Flood-Basalt Province: Geological Society of America Special Paper 239, p. 1-20.

Vlassopoulos, D., Goin, J., Zeliff, M, Papadopoulos, S.S., and Associates, Inc., Porcello, J., Tolan, T., Lindsey, K., 2009, Groundwater Geochemistry of the Columbia River Basalt Group Aquifer System: Columbia River Basin Ground Water Management Area of Adams, Franklin, Grant, and Lincoln Counties: Consultant report prepared for Columbia Basin GWMA, prepared by GSI Water Solutions, Inc., June 2009.

Watkins, N.D., and Baksi, A.K., 1974, Magnetostratigraphy and oroclinal folding of the Columbia River, Steens and Owyhee basalts in Oregon, Washington, and Idaho: America: Journal of Science, v. 274, p. 148-189. 


\section{Appendix A}

\section{XRF Analysis Data of Well-Cuttings}

Table A1: Well-cutting XRF bulk chemistry.

\begin{tabular}{|c|c|c|c|c|c|c|c|c|c|c|c|}
\hline $\begin{array}{l}\text { WASC } \\
\text { Well \# }\end{array}$ & 51348 & 51831 & 51831 & 51831 & 51831 & 51831 & 51831 & 51831 & 51831 & 3016 & 3015 \\
\hline $\begin{array}{l}\text { Sample } \\
\text { Depth } \\
(\mathrm{m}) \\
\end{array}$ & 30.5 & 131.1 & 140.2 & 149.4 & 160.0 & 184.4 & 208.8 & 227.1 & 269.7 & 94.5 & 67.1 \\
\hline Flow Unit & Lolo & Pomona & Rosalia & Rosalia & Rosalia & Rosalia & Sand Hollow & Sand Hollow & $\begin{array}{l}\text { Sand } \\
\text { Hollow }\end{array}$ & Pomona & Pomona \\
\hline Map Unit & Twpl & Tsp & Twpr & Twpr & Twpr & Twpr & Twfsh & Twfsh & Twfsh & Tsp & Tsp \\
\hline $\begin{array}{l}\text { UTM N } \\
\text { NAD83 }\end{array}$ & $\begin{array}{l}505697 \\
5\end{array}$ & 5057613 & 5057613 & 5057613 & $\begin{array}{l}505761 \\
3\end{array}$ & 5057613 & 5057613 & 5057613 & 5057613 & 5056913 & 5057380 \\
\hline $\begin{array}{l}\text { UTM E } \\
\text { NAD83 }\end{array}$ & 628184 & 629776 & 629776 & 629776 & 629776 & 629776 & 629776 & 629776 & 629776 & 627051 & 626911 \\
\hline \multicolumn{12}{|c|}{ Oxides, weight $\%$} \\
\hline $\mathrm{SiO}_{2}$ & 51.64 & 52.07 & 50.10 & 50.06 & 49.81 & 50.13 & 51.63 & 51.86 & 51.85 & 52.04 & 52.05 \\
\hline $\mathrm{TiO}_{2}$ & 3.502 & 1.658 & 3.711 & 3.698 & 3.677 & 3.680 & 3.000 & 3.000 & 2.949 & 1.677 & 1.654 \\
\hline $\mathrm{Al}_{2} \mathrm{O}_{3}$ & 14.53 & 14.71 & 12.95 & 12.95 & 12.74 & 12.87 & 13.47 & 13.37 & 13.30 & 14.64 & 14.62 \\
\hline $\mathrm{FeO}^{*}$ & 12.27 & 10.58 & 15.42 & 15.57 & 15.67 & 15.48 & 14.22 & 14.13 & 14.19 & 10.65 & 10.59 \\
\hline $\mathrm{MnO}$ & 0.185 & 0.183 & 0.233 & 0.236 & 0.251 & 0.244 & 0.220 & 0.235 & 0.223 & 0.185 & 0.184 \\
\hline $\mathrm{MgO}$ & 4.65 & 6.87 & 4.30 & 4.27 & 4.56 & 4.38 & 4.40 & 4.31 & 4.47 & 6.88 & 6.96 \\
\hline $\mathrm{CaO}$ & 8.43 & 10.70 & 8.65 & 8.68 & 8.53 & 8.33 & 8.58 & 8.45 & 8.22 & 10.67 & 10.69 \\
\hline $\mathrm{Na}_{2} \mathrm{O}$ & 2.69 & 2.34 & 2.63 & 2.61 & 2.72 & 2.83 & 2.73 & 2.85 & 2.95 & 2.41 & 2.36 \\
\hline $\mathrm{K}_{2} \mathrm{O}$ & 1.26 & 0.66 & 1.20 & 1.13 & 1.25 & 1.25 & 1.16 & 1.20 & 1.28 & 0.62 & 0.67 \\
\hline $\mathrm{P}_{2} \mathrm{O}_{5}$ & 0.842 & 0.227 & 0.796 & 0.793 & 0.798 & 0.810 & 0.581 & 0.590 & 0.570 & 0.231 & 0.225 \\
\hline \multicolumn{12}{|c|}{ Trace Elements, parts per million } \\
\hline $\mathrm{Ni}$ & 47 & 51 & 20 & 20 & 20 & 20 & 20 & 20 & 19 & 50 & 51 \\
\hline $\mathrm{Cr}$ & 96 & 99 & 9 & 8 & 8 & 8 & 42 & 39 & 40 & 93 & 98 \\
\hline Sc & 38 & 37 & 39 & 39 & 40 & 39 & 37 & 37 & 36 & 36 & 35 \\
\hline $\mathrm{V}$ & 366 & 280 & 421 & 423 & 424 & 423 & 416 & 418 & 415 & 283 & 284 \\
\hline $\mathrm{Ba}$ & 546 & 251 & 545 & 540 & 576 & 591 & 531 & 559 & 567 & 265 & 252 \\
\hline $\mathrm{Rb}$ & 33 & 15 & 32 & 30 & 34 & 31 & 29 & 31 & 34 & 14 & 15 \\
\hline $\mathrm{Sr}$ & 293 & 237 & 293 & 295 & 296 & 292 & 323 & 316 & 313 & 235 & 234 \\
\hline $\mathrm{Zr}$ & 200 & 137 & 229 & 227 & 231 & 231 & 190 & 192 & 192 & 139 & 137 \\
\hline
\end{tabular}


Table A1 continued: Well-cutting XRF bulk chemistry.

\begin{tabular}{|c|c|c|c|c|c|c|c|c|c|c|c|}
\hline $\begin{array}{l}\text { Cont'd } \\
\text { WASC } \\
\text { Well \# } \\
\end{array}$ & 51348 & 51831 & 51831 & 51831 & 51831 & 51831 & 51831 & 51831 & 51831 & 3016 & 3015 \\
\hline $\begin{array}{l}\text { Sample } \\
\text { Depth } \\
\text { (m) } \\
\end{array}$ & 30.5 & 131.1 & 140.2 & 149.4 & 160.0 & 184.4 & 208.8 & 227.1 & 269.7 & 94.5 & 67.1 \\
\hline $\mathrm{Y}$ & 47 & 30 & 51 & 50 & 50 & 51 & 41 & 42 & 41 & 30 & 30 \\
\hline $\mathrm{Nb}$ & 15.7 & 11.7 & 18.7 & 18.4 & 18.5 & 18.9 & 14.2 & 14.0 & 13.8 & 12.3 & 11.7 \\
\hline $\mathrm{Ga}$ & 22 & 19 & 22 & 22 & 22 & 22 & 23 & 20 & 22 & 19 & 18 \\
\hline $\mathrm{Cu}$ & 44 & 52 & 23 & 23 & 25 & 25 & 28 & 28 & 29 & 54 & 53 \\
\hline Zn & 152 & 96 & 157 & 159 & 158 & 156 & 141 & 142 & 141 & 97 & 98 \\
\hline $\mathrm{Pb}$ & 5 & 4 & 5 & 6 & 5 & 6 & 6 & 6 & 4 & 6 & 5 \\
\hline $\mathrm{La}$ & 30 & 20 & 32 & 31 & 30 & 29 & 23 & 26 & 23 & 18 & 17 \\
\hline $\mathrm{Ce}$ & 65 & 37 & 68 & 66 & 69 & 71 & 56 & 57 & 54 & 41 & 38 \\
\hline Th & 4 & 3 & 5 & 4 & 4 & 4 & 4 & 5 & 4 & 3 & 4 \\
\hline $\mathrm{Nd}$ & 38 & 20 & 40 & 40 & 43 & 39 & 33 & 34 & 32 & 23 & 22 \\
\hline $\mathrm{U}$ & 1 & 1 & 2 & 3 & 4 & 0 & 1 & 3 & 0 & 1 & 1 \\
\hline
\end{tabular}

Major element determinations have been normalized to a $100 \%$ total

on a volatile-free basis with total iron expressed as $\mathrm{FeO}$. 
Table A2: Well-cutting XRF bulk chemistry

\begin{tabular}{|c|c|c|c|c|c|c|c|c|c|c|c|c|}
\hline $\begin{array}{l}\text { WASC } \\
\text { Well \# }\end{array}$ & 2767 & 2767 & 2767 & 2851 & 2851 & 2219 & 2219 & 2219 & 2219 & 2219 & 2219 & 2219 \\
\hline \multicolumn{13}{|l|}{ Sample } \\
\hline $\begin{array}{l}\text { Depth } \\
\text { (m) }\end{array}$ & 7.0 & 20.7 & 25.3 & 53.3 & 59.4 & 88.4 & 115.8 & 128.0 & 131.1 & 140.2 & 149.4 & 153.9 \\
\hline $\begin{array}{l}\text { Flow } \\
\text { Unit }\end{array}$ & Pomona & $\begin{array}{l}\text { Fused } \\
\text { Tuff }\end{array}$ & Lolo & Pomona & Lolo & Lolo & Rosalia & Rosalia & Rosalia & Rosalia & $\begin{array}{l}\text { Sentinel } \\
\text { Gap }\end{array}$ & $\begin{array}{l}\text { Sentinel } \\
\text { Gap }\end{array}$ \\
\hline $\begin{array}{l}\text { Map } \\
\text { Unit }\end{array}$ & Tsp & $\mathrm{N} / \mathrm{A}$ & Twpl & Tsp & Twpl & Twpl & Twpr & Twpr & Twpr & Twpr & & \\
\hline $\begin{array}{l}\text { UTM N } \\
\text { NAD83 }\end{array}$ & 5057671 & 5057671 & 5057671 & 5058529 & 5058529 & 5055905 & 5055905 & 5055905 & 5055905 & 5055905 & 5055905 & $\begin{array}{l}505590 \\
5\end{array}$ \\
\hline $\begin{array}{l}\text { UTM E } \\
\text { NAD83 } \\
\text { Oxides, }\end{array}$ & $\begin{array}{l}626153 \\
\text { ight \% }\end{array}$ & 626153 & 626153 & 627336 & 627336 & 629949 & 629949 & 629949 & 629949 & 629949 & 629949 & 629949 \\
\hline $\mathrm{SiO}_{2}$ & 53.61 & 73.98 & 51.43 & 52.75 & 49.95 & 51.43 & 50.11 & 50.15 & 50.38 & 50.20 & 52.48 & 52.33 \\
\hline $\mathrm{TiO}_{2}$ & 1.707 & 0.584 & 3.647 & 1.733 & 3.312 & 3.613 & 3.699 & 3.953 & 3.864 & 4.073 & 3.044 & 3.061 \\
\hline $\mathrm{Al}_{2} \mathrm{O}_{3}$ & 15.19 & 12.30 & 15.36 & 15.33 & 13.88 & 15.01 & 12.84 & 13.59 & 13.41 & 13.82 & 13.20 & 13.10 \\
\hline $\mathrm{FeO}^{*}$ & 9.97 & 2.89 & 12.21 & 10.08 & 13.67 & 14.15 & 15.13 & 14.90 & 14.79 & 15.44 & 14.10 & 14.32 \\
\hline $\mathrm{MnO}$ & 0.158 & 0.050 & 0.225 & 0.181 & 0.255 & 0.233 & 0.250 & 0.232 & 0.263 & 0.241 & 0.217 & 0.222 \\
\hline $\mathrm{MgO}$ & 5.42 & 0.45 & 3.68 & 5.43 & 4.86 & 2.78 & 4.45 & 3.52 & 3.53 & 3.28 & 3.88 & 3.87 \\
\hline $\mathrm{CaO}$ & 10.53 & 1.50 & 8.73 & 11.10 & 9.93 & 8.31 & 8.66 & 9.18 & 9.07 & 8.61 & 8.09 & 8.11 \\
\hline $\mathrm{Na}_{2} \mathrm{O}$ & 2.54 & 2.22 & 2.90 & 2.48 & 2.60 & 2.79 & 2.68 & 2.64 & 2.53 & 2.49 & 2.95 & 2.93 \\
\hline $\mathrm{K}_{2} \mathrm{O}$ & 0.65 & 5.94 & 0.95 & 0.68 & 0.77 & 0.82 & 1.37 & 0.93 & 1.15 & 0.82 & 1.38 & 1.38 \\
\hline $\mathrm{P}_{2} \mathrm{O}_{5}$ & 0.235 & 0.094 & 0.868 & 0.242 & 0.781 & 0.867 & 0.812 & 0.894 & 1.014 & 1.022 & 0.666 & 0.672 \\
\hline \multicolumn{13}{|c|}{ Trace Elements, parts per million } \\
\hline $\mathrm{Ni}$ & 40 & 8 & 32 & 48 & 44 & 38 & 20 & 17 & 19 & 16 & 16 & 17 \\
\hline $\mathrm{Cr}$ & 98 & 11 & 101 & 101 & 91 & 95 & 9 & 8 & 9 & 10 & 15 & 17 \\
\hline Sc & 37 & 7 & 39 & 37 & 40 & 38 & 39 & 40 & 40 & 40 & 37 & 36 \\
\hline V & 276 & 44 & 386 & 300 & 367 & 337 & 424 & 440 & 436 & 422 & 403 & 399 \\
\hline $\mathrm{Ba}$ & 316 & 883 & 590 & 281 & 501 & 591 & 578 & 508 & 588 & 503 & 638 & 633 \\
\hline $\mathrm{Rb}$ & 17 & 199 & 16 & 15 & 18 & 18 & 33 & 28 & 35 & 27 & 32 & 31 \\
\hline $\mathrm{Sr}$ & 241 & 67 & 325 & 244 & 301 & 329 & 293 & 309 & 302 & 301 & 318 & 314 \\
\hline $\mathrm{Zr}$ & 139 & 415 & 202 & 142 & 189 & 199 & 230 & 232 & 235 & 235 & 214 & 214 \\
\hline $\mathrm{Y}$ & 31 & 53 & 43 & 33 & 45 & 45 & 51 & 53 & 60 & 61 & 45 & 45 \\
\hline $\mathrm{Nb}$ & 12.0 & 40.1 & 17.0 & 12.0 & 15.1 & 16.3 & 18.6 & 18.2 & 17.6 & 19.1 & 15.7 & 16.2 \\
\hline $\mathrm{Ga}$ & 20 & 19 & 23 & 18 & 23 & 22 & 22 & 22 & 22 & 22 & 21 & 22 \\
\hline $\mathrm{Cu}$ & 48 & 7 & 39 & 54 & 45 & 43 & 23 & 24 & 25 & 23 & 24 & 24 \\
\hline
\end{tabular}


Table A2 continued: Well-cutting XRF bulk chemistry

\begin{tabular}{|c|c|c|c|c|c|c|c|c|c|c|c|c|}
\hline $\begin{array}{l}\text { WASC } \\
\text { Well \# }\end{array}$ & 2767 & 2767 & 2767 & 2851 & 2851 & 2219 & 2219 & 2219 & 2219 & 2219 & 2219 & 2219 \\
\hline $\begin{array}{l}\text { Sample } \\
\text { Depth }\end{array}$ & 7.0 & 20.7 & 25.3 & 53.3 & 59.4 & 88.4 & 115.8 & 128.0 & 131.1 & 140.2 & 149.4 & 153.9 \\
\hline Zn & 97 & 55 & 154 & 102 & 140 & 145 & 160 & 164 & 170 & 176 & 150 & 150 \\
\hline $\mathrm{Pb}$ & 4 & 28 & 6 & 3 & 5 & 4 & 6 & 7 & 6 & 6 & 7 & 7 \\
\hline $\mathrm{La}$ & 19 & 75 & 26 & 20 & 28 & 30 & 29 & 33 & 35 & 34 & 27 & 28 \\
\hline $\mathrm{Ce}$ & 38 & 147 & 66 & 39 & 58 & 61 & 62 & 69 & 78 & 80 & 58 & 63 \\
\hline Th & 3 & 32 & 4 & 3 & 4 & 5 & 4 & 5 & 5 & 5 & 5 & 4 \\
\hline $\mathrm{Nd}$ & 22 & 54 & 38 & 23 & 38 & 37 & 39 & 42 & 44 & 47 & 35 & 37 \\
\hline U & 1 & 7 & 1 & 2 & 3 & 1 & 1 & 1 & 4 & 3 & 2 & 1 \\
\hline
\end{tabular}

*Major element determinations have been normalized to a $100 \%$ total

on a volatile-free basis with total iron expressed as FeO. 


\section{XRF Analysis Data of Hand Samples}

Table A3: XRF bulk chemistry for all hand samples.

\begin{tabular}{|c|c|c|c|c|c|c|c|}
\hline Sample Name & gage1 & gage 2 & gage3 & mol1 & har4 & har9 & for1 \\
\hline Flow Unit & Pomona & Lolo & Lolo & Lolo & Lolo & Rosalia & Pomona \\
\hline Map Unit & Tsp & Twpl & Twpl & Twpl & Twpl & Twpr & Tsp \\
\hline $\begin{array}{l}\text { UTM N (NAD } \\
83 \text { ) }\end{array}$ & 5056562 & 5056475 & 5056444 & 5057252 & 628785 & 5056301 & 5057340.3 \\
\hline $\begin{array}{l}\text { UTM E (NAD } \\
\text { 83) } \\
\text { Oxides, weigh }\end{array}$ & 626503 & 626488 & 626503 & 626530 & 5055484 & 627963 & 627555 \\
\hline $\mathrm{SiO}_{2}$ & 52.15 & 49.59 & 49.76 & 51.97 & 49.71 & 49.93 & 52.00 \\
\hline $\mathrm{TiO}_{2}$ & 1.655 & 3.158 & 3.184 & 3.388 & 3.227 & 3.698 & 1.679 \\
\hline $\mathrm{Al}_{2} \mathrm{O}_{3}$ & 14.58 & 13.54 & 13.56 & 14.37 & 13.52 & 13.17 & 14.73 \\
\hline $\mathrm{FeO}^{*}$ & 10.78 & 14.42 & 14.15 & 11.54 & 14.05 & 15.43 & 10.58 \\
\hline $\mathrm{MnO}$ & 0.185 & 0.229 & 0.237 & 0.499 & 0.237 & 0.216 & 0.182 \\
\hline MgO & 6.49 & 5.48 & 5.31 & 3.62 & 5.28 & 4.24 & 6.76 \\
\hline $\mathrm{CaO}$ & 10.79 & 8.97 & 9.13 & 9.97 & 9.27 & 8.83 & 10.72 \\
\hline $\mathrm{Na}_{2} \mathrm{O}$ & 2.52 & 2.76 & 2.82 & 2.83 & 2.71 & 2.74 & 2.51 \\
\hline $\mathrm{K}_{2} \mathrm{O}$ & 0.61 & 1.07 & 1.08 & 1.00 & 1.21 & 0.94 & 0.61 \\
\hline $\mathrm{P}_{2} \mathrm{O}_{5}$ & 0.231 & 0.766 & 0.775 & 0.821 & 0.788 & 0.818 & 0.236 \\
\hline \multicolumn{8}{|c|}{ Trace Elements, parts per million } \\
\hline $\mathrm{Ni}$ & 48 & 43 & 44 & 29 & 42 & 21 & 49 \\
\hline $\mathrm{Cr}$ & 95 & 90 & 89 & 92 & 88 & 7 & 98 \\
\hline $\mathrm{Sc}$ & 36 & 37 & 38 & 39 & 38 & 39 & 35 \\
\hline V & 273 & 347 & 355 & 369 & 360 & 416 & 280 \\
\hline $\mathrm{Ba}$ & 257 & 510 & 511 & 588 & 550 & 584 & 292 \\
\hline $\mathrm{Rb}$ & 14 & 28 & 26 & 27 & 28 & 26 & 12 \\
\hline $\mathrm{Sr}$ & 228 & 281 & 287 & 308 & 297 & 308 & 236 \\
\hline $\mathrm{Zr}$ & 136 & 184 & 186 & 194 & 193 & 222 & 140 \\
\hline $\mathrm{Y}$ & 29 & 43 & 44 & 48 & 45 & 50 & 29 \\
\hline $\mathrm{Nb}$ & 11.5 & 14.5 & 14.3 & 15.4 & 15.0 & 17.2 & 12.0 \\
\hline $\mathrm{Ga}$ & 17 & 21 & 21 & 22 & 21 & 23 & 18 \\
\hline $\mathrm{Cu}$ & 49 & 42 & 42 & 44 & 43 & 21 & 49 \\
\hline $\mathrm{Zn}$ & 94 & 143 & 141 & 172 & 143 & 157 & 100 \\
\hline $\mathrm{Pb}$ & 3 & 6 & 5 & 5 & 6 & 6 & 4 \\
\hline La & 20 & 25 & 26 & 25 & 27 & 26 & 18 \\
\hline $\mathrm{Ce}$ & 39 & 57 & 63 & 62 & 64 & 68 & 37 \\
\hline Th & 2 & 4 & 4 & 5 & 5 & 4 & 4 \\
\hline $\mathrm{Nd}$ & 20 & 33 & 37 & 37 & 37 & 39 & 19 \\
\hline U & 2 & 2 & 0 & 2 & 2 & 2 & 2 \\
\hline
\end{tabular}

Major element determinations have been normalized to a $100 \%$ total on a volatile-free basis with total iron expressed as $\mathrm{FeO}$. 


\section{Appendix B}

\section{Well Logs}

All well logs utilized for this study are included below.

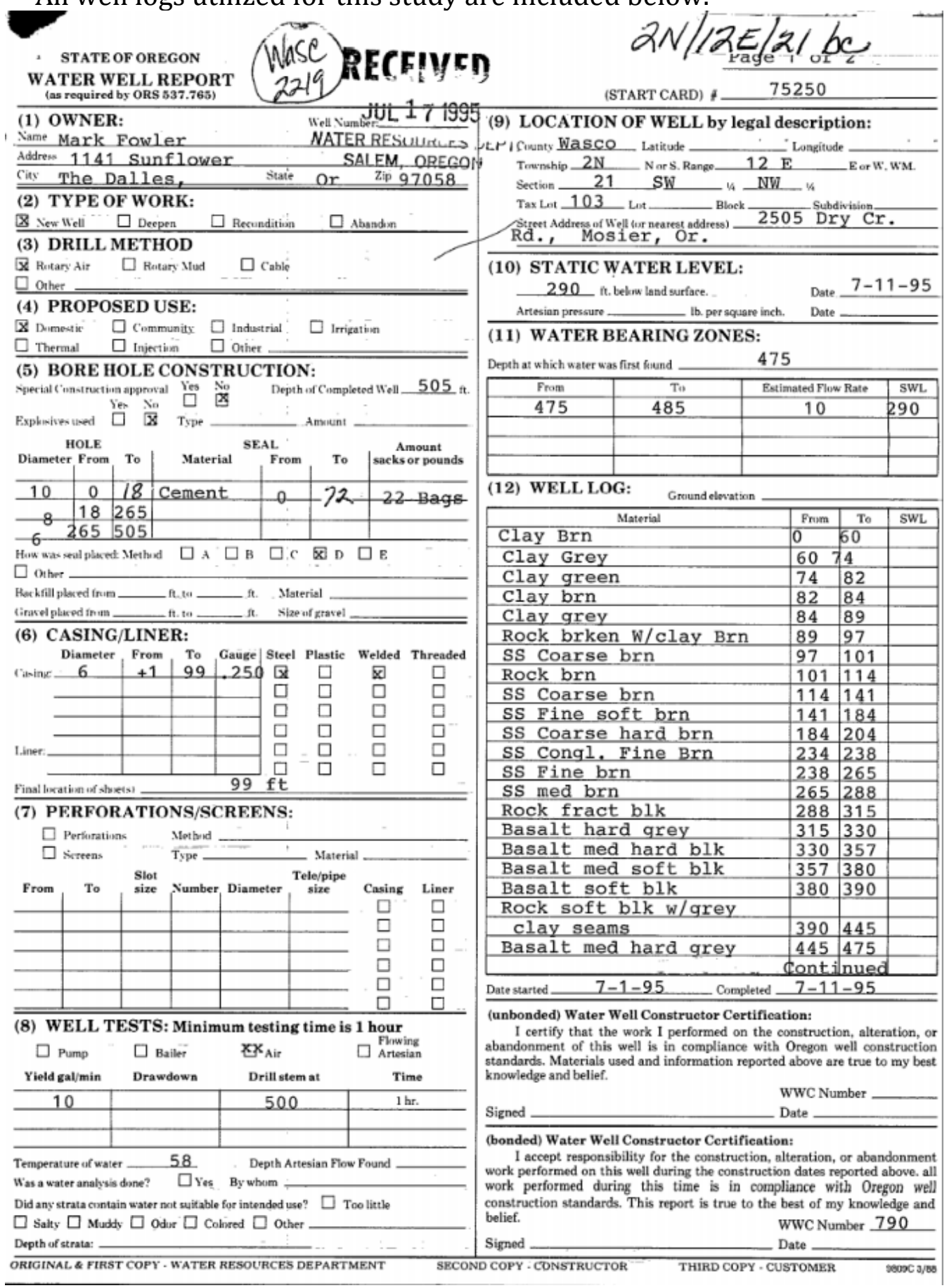

Figure B1: WASC 2219 
, STATEOF OREGON

WATER WELL REPORT

RECEIVEn

(as required by ORS 537.765)

(1) OWNER:

Name Mark Fowler

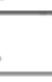

Well Number JUL I

(START CARD) $\# \quad 75250$

\begin{tabular}{|c|c|c|c|}
\hline \multicolumn{4}{|c|}{ Addren $\quad 1141$ Sunf } \\
\hline Ciny The & Dalles, & State & Or. Zip 97058 \\
\hline \multicolumn{4}{|c|}{ (2) TYPE OF WORK: } \\
\hline 므 Vew Well & $\square$ Deepen & $\square$ Recoundition & $\square$ Abandinn \\
\hline \multicolumn{4}{|c|}{ (3) DRILL METHOD } \\
\hline $\begin{array}{l}\square \text { Risary Air } \\
\square \text { Otber }\end{array}$ & $\square$ Rinary Mlod & $\square$ Cable & \\
\hline \multicolumn{4}{|c|}{ (4) PROPOSED USE: } \\
\hline $\begin{array}{l}\square \text { Disnertic } \\
\square \text { Thermal }\end{array}$ & $\begin{array}{l}\square \text { Community } \\
\square \text { Injectian }\end{array}$ & $\begin{array}{l}\square \text { Industrial } \\
\square \text { Other }\end{array}$ & $\square$ Irrization \\
\hline
\end{tabular}

\section{(5) BORE HOLE CONSTRUCTION:}

1 siecial (ienstrustinn approval Yes Nis Depth or Completed Well____ f Yis No $\square \square$

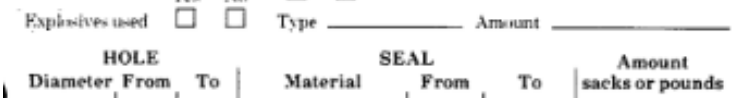
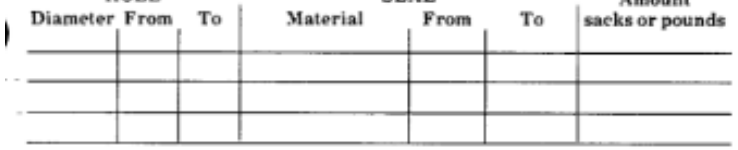

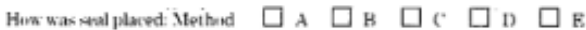

$\square$ Other

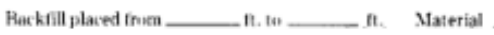

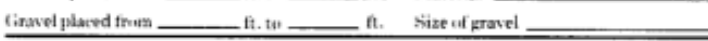

(6) CASING/LINER:

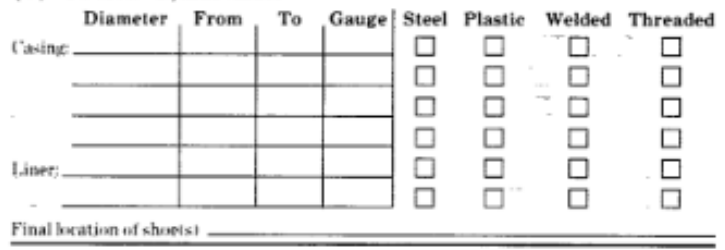

\section{(7) PERFORATIONS/SCREENS:}

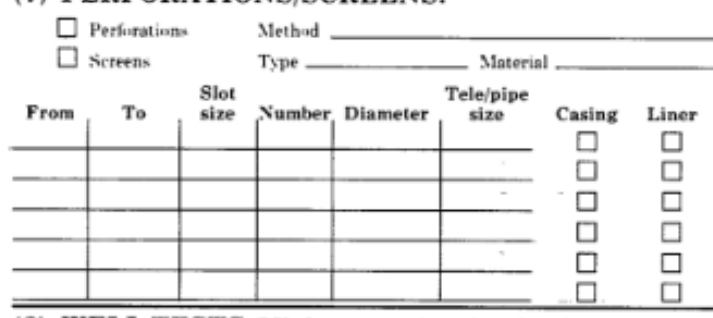

(8) WELL TESTS: Minimum testing time is 1 hour

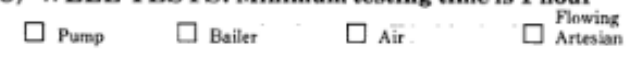

Yield gal/min Drawdown Drill stem at Time

\begin{tabular}{l|c|c|c}
\hline & & & $1 \mathrm{hr}$. \\
\hline & & & \\
\hline & & & \\
\hline
\end{tabular}

Temperature of water

Depth Artesian Flow Found

Was a water analysis done? $\square$ Yes By whom

Did any strats cuntain water not suitsble for intended use? $\square$ Too little

$\square$ Salty $\square$ Muddy $\square$ Odor $\square$ Colored $\square$ Other

Depth of strata:

ORIGINAL \& FIRST COPY - WATER RESOURCES DEPARTMENT

Figure B2: WASC 2219 page 2

Date started $7-1-95-$ Completed

(12) WELL LOG: Ground elevation

\begin{tabular}{|l|c|c|c|}
\hline \multicolumn{1}{|c|}{ Material } & From & To & SWL \\
\hline Basalt fract blk W/B & 475 & 485 & \\
\hline Basalt hard grey & 485 & 505 & 290 \\
\hline
\end{tabular}

(unbonded) Water Well Construetor Certifieation:

I certify that the work I performed on the construction, alteration, or abandonment of this well is in compliance with Oregon well construction standards. Materials used and information reported above are true to my best. knowledge and belief.

Signed

WWC Number

(bonded) Water Well Constructor Certification:

I accept responsibility for the construction, alteration, or abandonment. work performed on this well during the construction dates reported above. all work performed during this tige is in compliance with Oregon well construction standards. This report is true to the best of my knowledge and belief. WwC Number 790 Signedr $-\mathrm{CLC}$ Date $7-13-95$ D COPY - CONSTRUCTOR THIRD COPY - CUSTOMER 


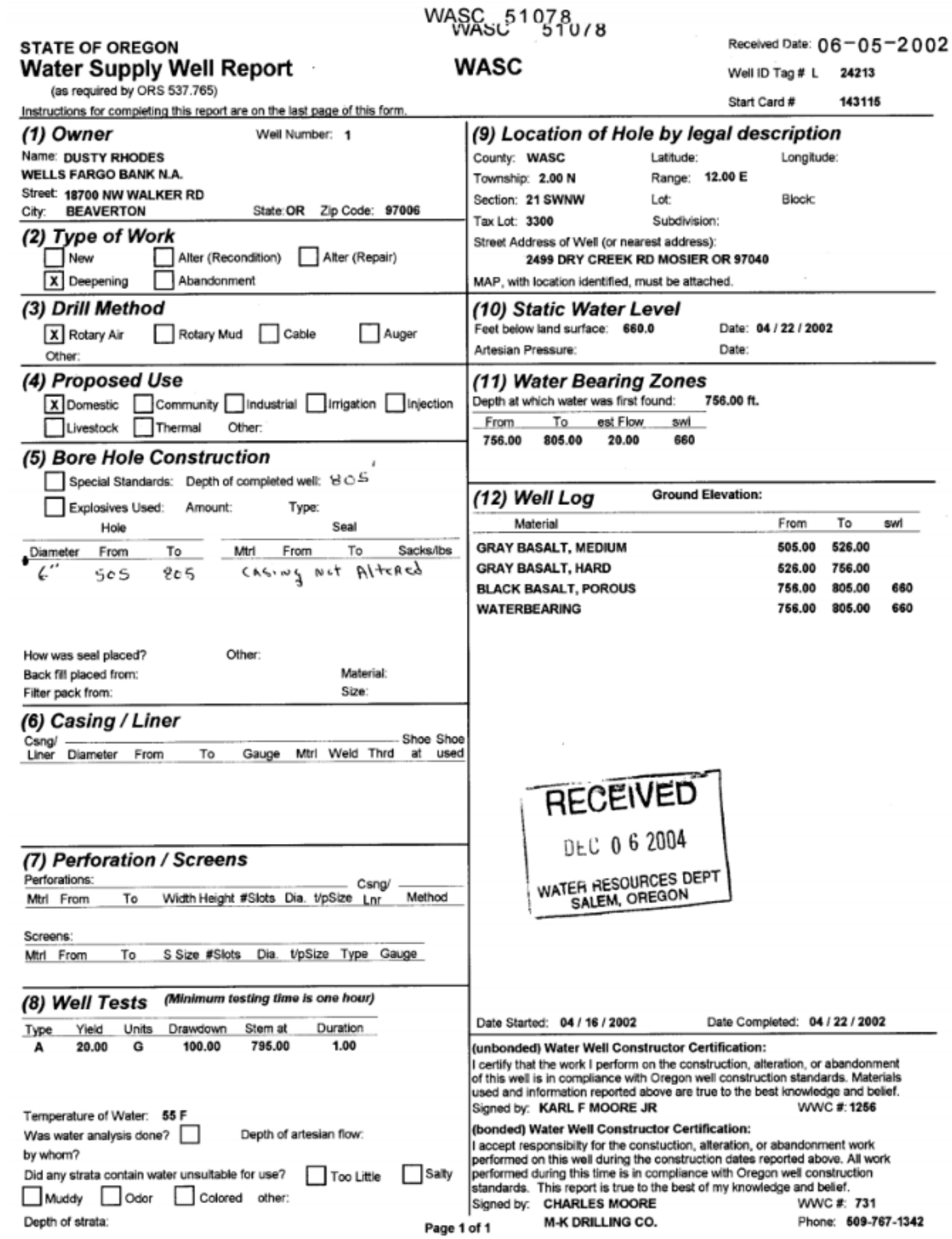

Figure B3: WASC 51078 (Deepening of WASC 2219) 


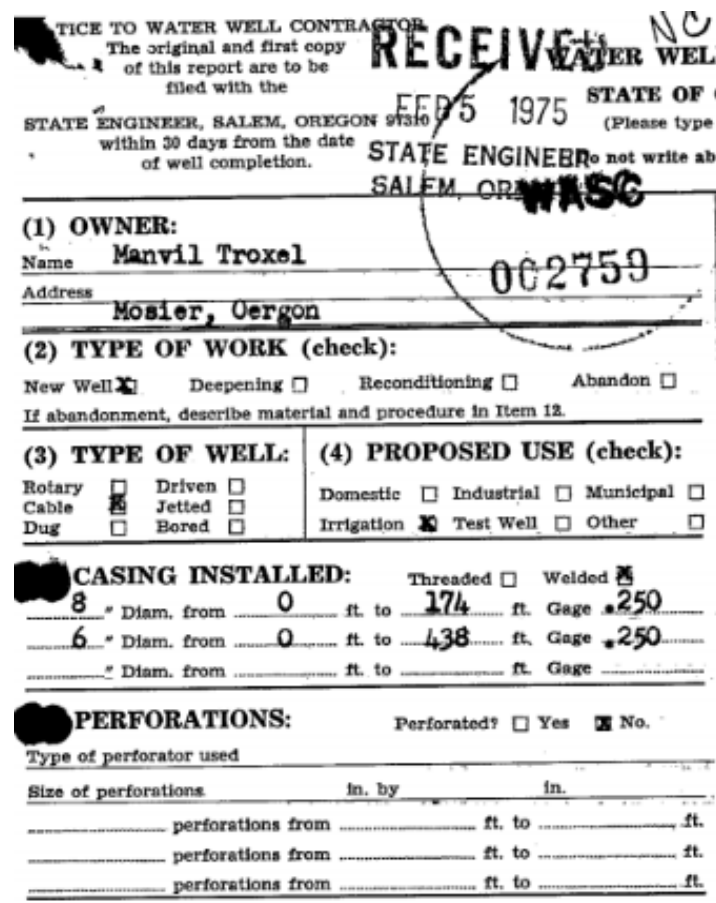

(7) SCREENS: Well sereen installed? $\square$ Yes $\mathbf{x}$ No

Manufaeturer's Name ._- Model No.

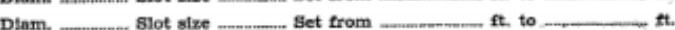

(8) WELL TESTS:
Prawdown is amourt water level to
lowered below atatle level

Was a pump test made? D Yes $\mathbf{X}$ No If yes, by whom? '

gal/min. wlth th, drawdown after hrs.

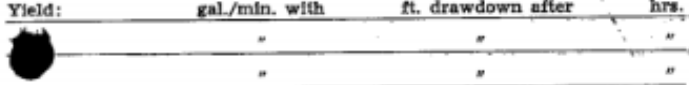

Baller test gal./min. with ft. drawdown after hira

Artestan now 300 B.p.m.

(9) CONSTRUCTION:

Well sent-Material used cement \& bentonite

Well acoted rom land ourace to. 1 .

Diameter of well bore to bottom of seal 12 in.

Dinmeter of well bore below seal 8 in. to $478^{\circ}$

Number of sacks of cement used in well seal ... 12

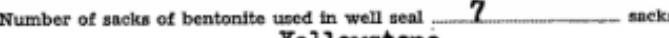

Brand name of bentonite Yelloustone

Number of pounds of bentonite per 100 gallons

of water 200

Was a drive shoe used? $\mathbf{X}$ Yes $\square$ No Plugs ........ Slze: locatton __... ft.

Did any atrata contain unuspble water $\square$ Yes 9 No

Type of water? depth of strata

Method of sealling strata off

Was well zravel paekedt $\square$ Yes $g^{\circ}$ No Slize of gravel: .........

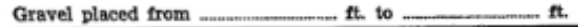

RECEIVED ENe $=12$ ad

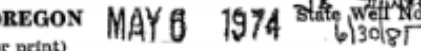

\$TATE ENGINEER ${ }^{\text {tate Permit No. }}$ G6252 SALEM. OREGON

(16) LOCATION OF WELL:

County Wasco Driller's well number

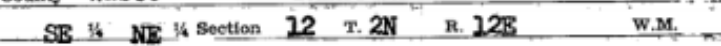

Bearting and distance from sectlon or subdivision corner $30^{\circ} \mathrm{N}$ of SB t corner

(11) WATER LEVEL: Completed well.

Depth at whteh water was first found

106 at.

Static, level it. below land surface. Date

Artectan pressure 26 ibs. per square Inch. Date $4 / 8 / 74$

(12) WELL LOG: Dlameter of well below easing - 6 Depth Arilled 553 ft. Depth of completed well $553 \quad$ ft.

Formation: Describe color, texture, graln slze and atructure of materials; and ahow thickness and nature of each stratum and aquifer penetrated

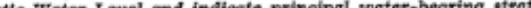
position of Static Water Level and inatcute principal water-bearing sirata.

\section{Soin}

Sand It, brown

Conglamerate med

Ciny Bry

Begalt gray burd

Cley brown

Basalt gray hard

Sand IIne yellow WB

Clay 1t. gray

Basalt blue hard

Basalt gray hard

\begin{tabular}{l|c|c|c} 
Basalt blue hard & 290 & 322 & \\
Basalt gray & 322 & 357 & 12 \\
\hline Pressure grout to $165^{\prime}$ with $97^{\prime 2}$ scks cement \\
\hline
\end{tabular}

\begin{tabular}{l|c|c|c} 
Basalt blue hard & 290 & 322 & \\
Basalt gray & 322 & 357 & 12 \\
\hline Pressure grout to $165^{\prime}$ with $97^{\prime 2}$ scks cement \\
\hline
\end{tabular}

Clays green \& grays

Claystone green WB

Bassit gray soft WB

Claystone green

Work started Peb. 6

74 Completed Apr11

Drilling Machine Operator's Certification:

This well was constructed under my direct supervision. Materials used and information best knowledge and bellef.

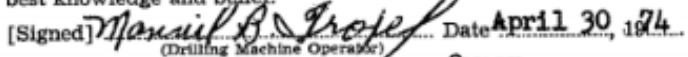

Drilling Machine Operator's License No. Owmer

Water Well Contractor's Certification:

This well was drilled under my jurisdiction and this report in true to the best of my knowledge and belief.

Name (Person, firm or corporation) (Type or print)

Addre

[Signed]

Contractor's License No.

Water well Contractor)

Date

(USB ADDITIONAL BIEETS IF NECESBARY)

Figure B4: WASC 2579 


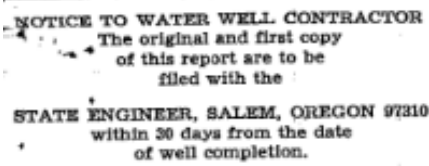

WATER WELL REPORT STATE OF OREGON (Plense type or print) (Do not write above this line)

\section{- Per Ho Righto

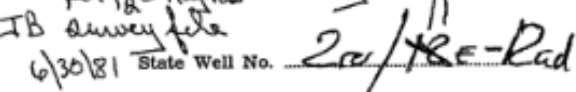

State Permit No

\section{(1) OWNER:}

Name.

Addrese

(2) TYPE OF WORK (check):

New Well $\square$ Deepening $\square$ Reconditioning $\square$ Abandon $\square$ If abandonment, describe material and procedure in Item 12

(3) TYPE OF WELL: (4) PROPOSED USE (check):

Rotary
Cable
Dug

CASING INSTALLED Irigation $\square$ Test Well $\square$ Other

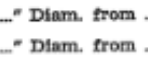

PERFORATIONS:

Perforated? $\square$ Yes $\square$ No

Type of perforator used

Size of perforations

perforations from

perforations from In. by

t. to in

perforations from

Well screen installeds $\square$ Yes $\square$ No

(7) SCREENS:

Model No.

Type.

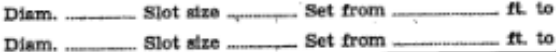

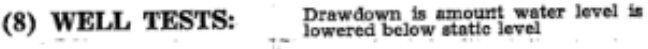

Was a pump test made? $\square$ Yes $\square$ No If yes, by whom?

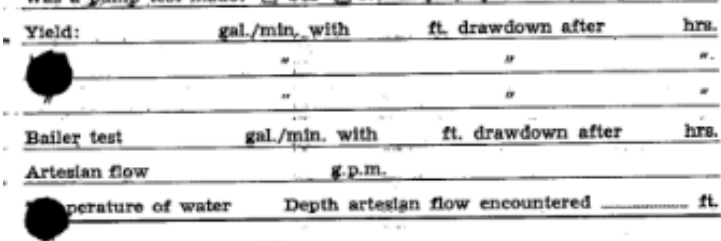

\section{(9) CONSTRUCTION:}

Well seal-Materlal used

Well sealed from land surface to.

Diameter of well bore to bottom of sea

Diameter of well bore below seal

seal -

Number of sacks of cement used in well seel

Number of ascks of bentonite used in well seal

Brand name of bentonite

Number of pounds of bentonite per 100 gallons

of water

1bs. $/ 200$ gals

Was a drive shoe used? $\square$ Yes $\square$ No Plugs ..._._. Sixe: loeation _...... t

Did any strata contain unusable water? $\square$ Yes $\square$ No

Type of water? depth of atrata

Method of sealing strata off

Was well gravel packed? $\square$ Yes $\square$ No Sixe of gravel:

Gravel placed from
(10) LOCATION OF WELL:

County _....... Driller's well number

14 1/ Section - T. R.

Bearing and distance from section or subdiviation corner

(11) WATER LEVEL; Completed well.

Depth at which water was first found -

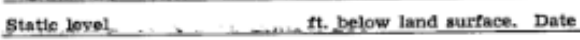

Artesian prensure $\quad$ Ibs. per square inch. Date

(12) WELL LOG: Diameter of well below cestng

Depth drilled ft. Depth of completed well

Formation: Describe color, texture, grain aive and atructure of materinls

and show thiekness and nature of each stratum and squifer penetrated, with at least one entry for each change of formation. Report each change tin position of Stutic Wuler Level and indieate primeipal water-bearing strate.

\begin{tabular}{|c|c|c|c|}
\hline MATERIAL & From & To & swL \\
\hline
\end{tabular}

\section{Claystone gray}

Rock black \& green soft

Basalt gray hard

Besalt gray FZ WB

Basalt gray hard

Claystone dik. green WB

Bagalt gray hard

Scoria black WB

Besalt gray WB

After setting $6^{\text {" }}$ liner pressure greut from

$429^{\prime}$ to land surface

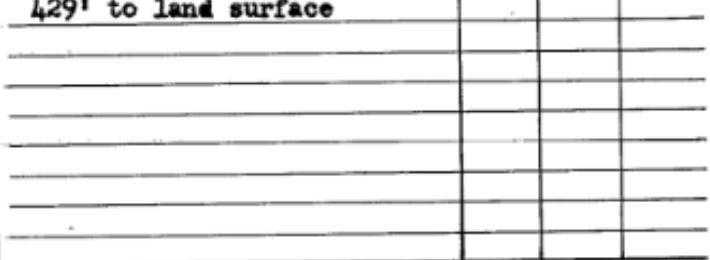

Work started _...... 19 Completed

\begin{tabular}{l|r|r}
\hline 82 & 487 & \\
\hline
\end{tabular}

Date well drilling machine moved off of well

$487 \quad 494$

$494 \quad 513$

513

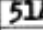

514521

524525

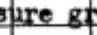

Drilling Machine Operator's Certifleation:

This well was constructed under my direct supervision. Materials used and information reported above are true to my best knowledge and bolig: Drilling Machine Operator's License No.

\section{Water Well Contractor's Certification:}

This well was drilled under my Jurisdiction and this report is true to the best of my knowledge and bellef

Name

Address

(Person, firm or corporstion) (Type or print)

[Signed] Water well Contractor)

Contractor's License No. _.._........ Date $\rightarrow, 19 \ldots$. sp*4sose-11

Figure B5: WASC 2759 page 2 


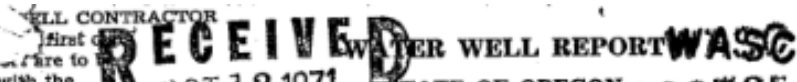 Filded wihn the BUCT 131971 STATE OF OREGON 002765

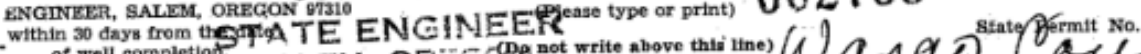 - within 30 days frometis?}

\section{1) OWNER: \\ Name \\ $C$ \\ Addrees \\ MOSIER}

\section{(2) TYPE OF WORK (check):}

Now Well $X$ Deepening $\square \quad$ Recondittoning $\square \quad$ Abandon $\square$ If abandonment, describe material and procedure in Item 12.

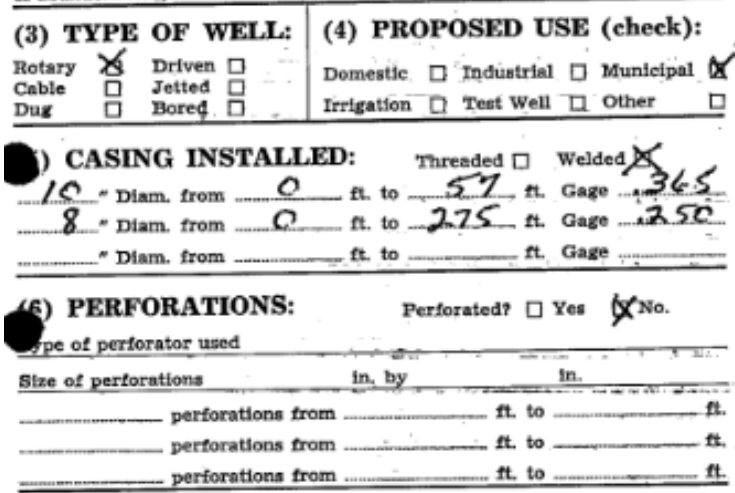

(7) SCREENS: Well screen installedp $\square$ Yes $X_{\text {No }}$

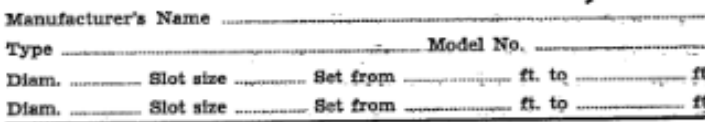

(8) WELL TESTS: $\quad \begin{aligned} & \text { prowdown is amourt water level in } \\ & \text { lowered below atatte level }\end{aligned}$

Was a pump test made? $\square$ Yes $\forall$ No If yes, by whom?

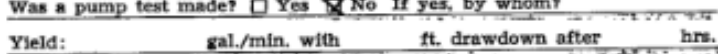

\begin{tabular}{|c|c|c|c|}
\hline & $*$ & . & \\
\hline Bafler test & gal. $/ \mathrm{min}$, with & ft. drawdown atter & hra. \\
\hline Artesten now & 151 8.p.m. & $80 \angle B S 3 H O$ & $E F$ \\
\hline
\end{tabular}
Temperature of water $59^{\circ}$ Depth artestan nlow encountered 280 it

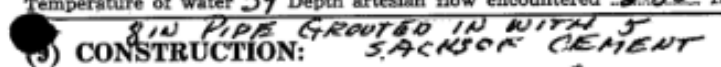
Well sen-Material used CEMENT GROUT well sealed from tand surface to ... 57 it. Dlameter of well bore to bottom of seal ...12\% in. Dlameter of well bore below seal $-10-G$ in.

Number of sacks of cement used in well seal ... 15

Wumber of sackses of bentonito used in well seal

Brand name of bentonite

Number of pounds of bentonite per 100 gallons

of water

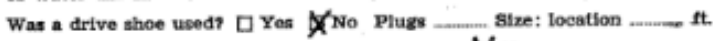
Did any strata contain unusable water? $\square$ Yea $X$ No

Type of water? depth of atrata

Method of sealling strata off

Was well gravel paeked? $\square$ Yes $X_{\text {No }}$ size of gravel:

Gravel placed from (10) LOCATIONOF WELL:
County HCOD R W E Erimer's well number $529 \mathrm{C}$ sw' NE 3 section $/ 2$ т. $2 N_{\text {R }} \| E$ w.M. Bearing and distance trum section or mubdfistion corner Com

(11) WATER LEVEL: Completed well. Depth at which water was first found 2ag 86 th Static level $7 \angle 0 \omega 1 N G-$ te below land surface. Date $9 / 22 / 71$
Artestan pressure 80 fos. per square inch. Date $9 / 22 / 71$ (12) WELL LOG: Dtameter of well below easing 6 Depth drilled 340 t. Depth of completed well $340 \mathrm{Oth}$ Formation: Describe color, texture, grain nitze and structure of materlals; and show thicelcnoss and nature of each stratum and aquifer penetrated, With at least one entry for each change of formation. Roport each change \begin{tabular}{c|c|c|c|}
\hline MATERTAL & mom & To & swi \\
\hline
\end{tabular}

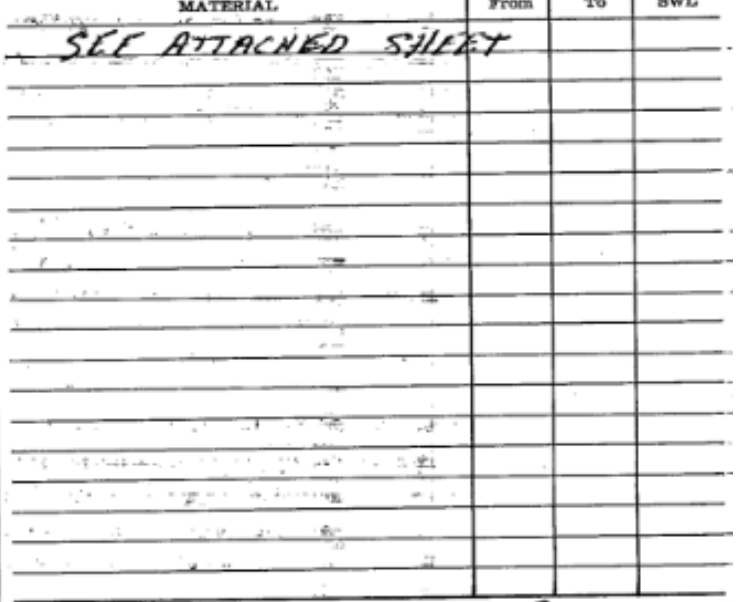

Work atarted VucY $21107 /$ completed SEPT 221971 Date well driling machine moved oft of well OCT $6 \quad 1071$ Drilling Mnehine Operator's Certifieation:

This well was conistructed under my direct supervision. Materials used and information reported above are true to my Materials used and inform

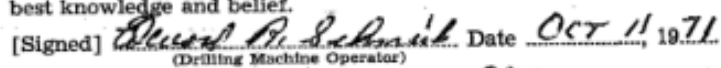
Drilling Machine Operator's License No. 56./

\section{Water Well Contractor's Certifieation:}

This well was drilled under my jurtsdiction and this report is

true to the best of my knowledge and beliet.

Name A (Perbon, tima or corporation) Address R1OSE SUNSET $\angle A N E$ PORT $\angle A N O$, QRE

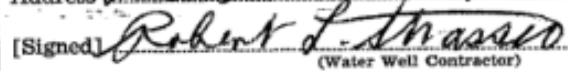

Contractor's License No. To Date . OCT II, 1971 


\section{R. J. Strasser Drilling Co. \\ 8110 S. E. Sunset Lano \\ Portland, Oregon 97206 \\ October 10, 1971}

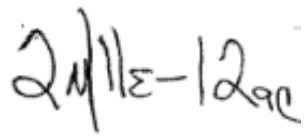

Log of City of Mosier well no. 3

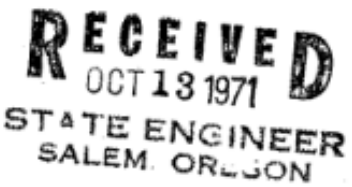

)

top soil

brown clay

sandy clay and boulders

broken brown basalt

meium hard grey basalt

hard grey basalt

broken grey basalt

hard light grey basalt

medium hard brown basalt

medium hard grey basalt

brown cinders

packed grey sand

blue clay

dark grey basalt

broken grey basalt

hard grey basalt

broken grey basalt

hard grey basalt

porous grey basalt

medium hard grey basalt

$0-\quad 1$
$1-5$
$5-10$
$10-24$
$24-30$
$30-86$
$86-87$
$87-176$
$176-188$
$188-193$
$193-224$
$224-255$
$255-266$
$266-285$
$285-286$
$286-304$
$304-315$
$315-320$
$320-338$
$338-340$

ST ATE ENGINEER

1
5
0
24
0
6
7
6
8
3
4
5
6
5
6
4
5
0
8
30

Figure B7: WASC 2765, page 2. 
NOTICE TO WATER WFLLI CONTRACTOR The original and tirst copy ot this report are to
flled with the

BTATE ENGINEER, SALEM, OREGON g7310 date 70296 of well completion.

\section{(1) OWNER:}

Name c

Address CTYY OF MOSIFR

(2) TYPE OF WORK (check):

New Well $\square$ Deepentes' $X$ Reconditioning $\square$ Abandon $\square$ If abandonment, describe material and procedure in Item 12.

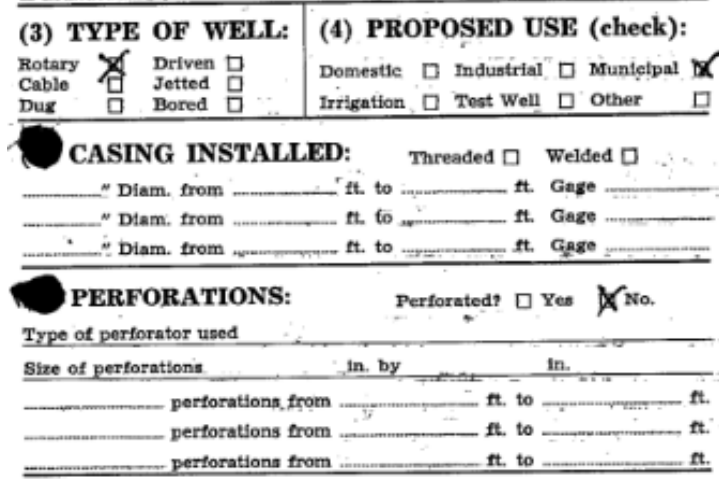

(7) SCREENS; _. Well sereen installedt ㅁ Yes $\$ \subset$ No

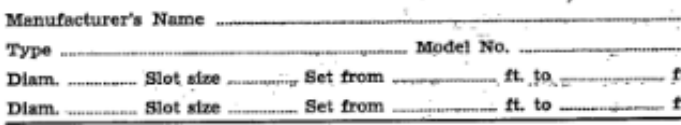

Dlam.

Was a pump test mader $\square$ Yes $X$ No If yes, by whom?

Yleld: $\quad$ gal $/ \mathrm{min}$ with ft. drawdown after

Baller test gal. $/ \mathrm{min}$. with it. drawdown after hrs. Artestan flow 400 g.p.m.

perature of water $54^{\circ}$ epth artestan flow encountered _....... It.

(9) CONSTRUCTION:

Well senl-Material used

Well sealed trom land surface to

Diameter of well bore to bottom of seal

Diameter of wen bare below seal

Number of sacks of cement used in well seal

Number of accke of bentonte wed in well seal .

Number of pounds of bentonite per 100 gallons

of water Ibs./100 sals

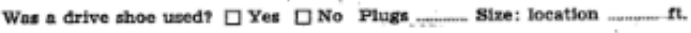
Did any strata contain unusable water? $\square$ Yes $\square$ No

Type of water? depth of strata

Method of sealling strate off Was well gravel paeked? $\square$ Yes $\square$ No Stze of gravel: Gravel placed from

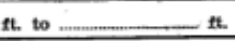

\section{(10) LOCATION OF WELL:} county HoOP RWERDriller's well number 5240 $S W_{4} N E_{4}$ section $/ 2$ T. $2 N_{R} \| E$ w.M. Besiring and distance trom sectlon or mubdivision corner

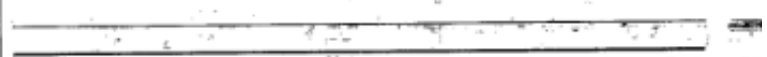
(ii) WATER LEVEL: Completed well.

Depth at which water whs first found กt. 2

Static level tt. below land surface. Date Artesten pressure $\quad 76 \quad \frac{15}{15}$. per square inch. Date $6 / 29 / 73$

(12) WELL LOG: Diameter of well below easing ... 6 Depth drilled $64 \mathrm{tt}$. Depth of completed well $404 \mathrm{st}$ Formation: Déseribe collor, texture, graln sifze and structure of materlals; and show thickneas and nature of ench stratum and aquifer penetrated, with at lesst one entry for each chänge of formation. Report each change in posittion of Static Water Level and indicate prinelpat vater-bearing strata.

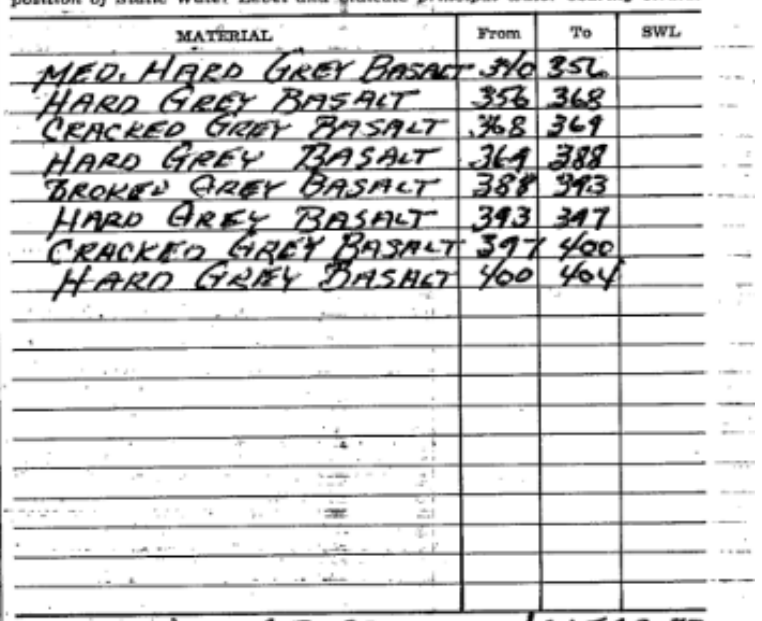

Work started JUNE $2519 / 3$ completed JeNe $99_{19} 73$ Date well driling machine moved otf of well Jvike $2919 \mathrm{Z}$ Drilling Machine Operator's Certification:

This well was constructed under my direct supervision. best knowledge and belief.

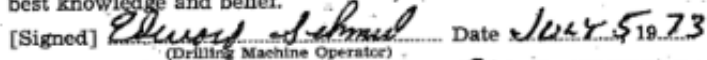
Drilling Machine Operator's License No. S. L.C.

Water Well Contraetor's Certification:

This well was drilled under my jurisdiction and this report is

true to the best of my knowledge and belief Name A P Persoa, firm oc corporation)

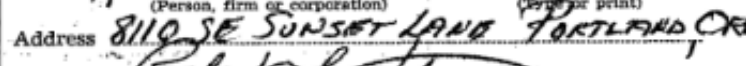

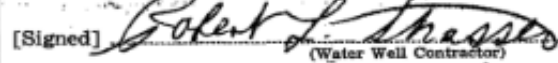

Contractor's License No. 10 Date $1, \ldots 4.5,1973$

Figure B8: WASC 2764 (Deepening of WASC 2765) 
WHS RECEIVED

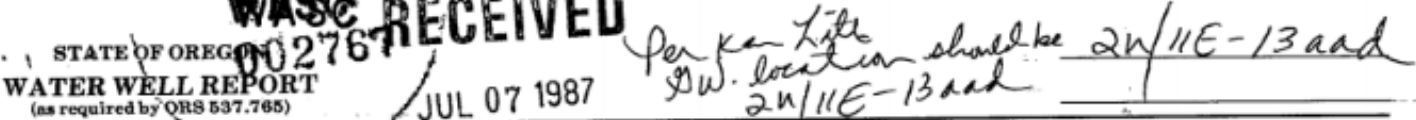

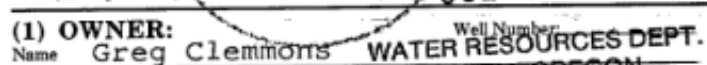
Name Greg Cleminoms WATER RESOUREGON
Address 6936 SW 54 th SALEM, OREGON City Portland, Oregon Slato $\quad$ Zip 97219

(2) TYPE OF WORK:

Q New Well $\square$ Deepen $\quad \square$ Recondition $\quad \square$ Abandon

(3) DRILL METHOD

ए Rotary Air $\square$ Rotary Mud $\square$ Cable

(4) PROPOSED USE:

ए. Domestic $\square$ Community $\square$ Industrial $\square$ Irrigation

$\square$ Thermal $\quad \square$ Injection $\quad \square$ Other

BORE HOLE CONSTRUCTION:

Construction approval Yes No Depèth of Completed Well - Be fit. Yes No $\square$ is

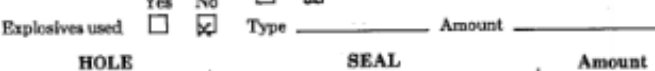

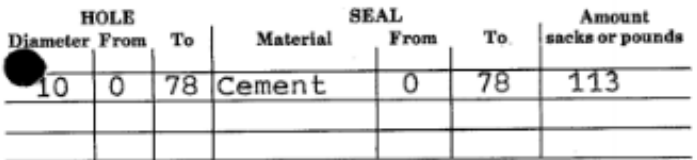

How was seal placed Method $\square$ A $\square$ Bं $\square$ c $\square$ D $\square$ B

$\square$ other Presure grouted

Backfill placed from _ n to to ft. Material

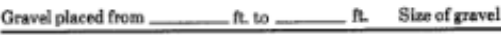

(6) CASING/LINER:

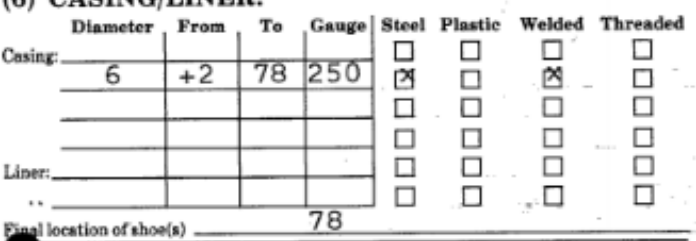

PERFORATIONS/SCREENS:
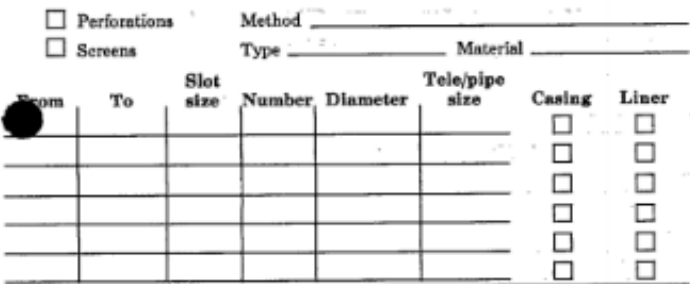

(8) WELL TESTS: Minimum testing time is 1 hour.

$\square$ Pump $\square$ Bailer $\quad$ B Air $\quad \square$ Artesing

Yield gal/min Drawdown Drill stem at Time

\begin{tabular}{l|c|c|c}
\hline & & & $1 \mathrm{hr}$. \\
\hline 100 & 2 & 89 & $1 \mathrm{hr}$. \\
\hline & & & \\
\hline
\end{tabular}

Temperature of water __. _ _..... Depth Artesina Flow Found

Was a water annalyzia done? $\square$ Yes By whom

Did any struta contain water sot suitable for intended use? T. Too litele

$\square$ Salty $\square$ Muddy $\square$ Oder 7 Coloned $\square$ Ocher

Depth of strata:

WHITE COPIES - WATER RESOURCES DEPARTMEN

Figure B9: WASC 2767

(9) LOCATION OF WELL by legal deseription:

County Lasce Latitude Longitude

Townshig N \$V Nor S, Range - $12 \mathrm{E}$

Section $18-$ SW $14-$ SW 14

Tax Lot Lot__ Block___ Subdivision.

Street Address of Well (or nesrest addresa)

(10) STATIC WATER LEVEL:

Date $6 / 4$

(11) WATER BEARING ZONES:

Depth at which water was first found 15 '

\begin{tabular}{|c|r|c|c|}
\hline From & To & Estimated Flow Rate & SWL \\
\hline $\mathbf{2}$ & 15 & $?$ & $?$ \\
\hline 55 & 2 & 8 & $?$ \\
\hline 85 & 89 & 100 & $8^{\prime}$ \\
\hline
\end{tabular}

(12) WELL LOG: Ground elevation 400

\begin{tabular}{|c|c|c|c|}
\hline Material & From & To & SWL \\
\hline
\end{tabular}

Soil

Gravel WB

Basalt gray

Clay tan

Basalt gray breken

Sandstone tan

Basalt gray wi

green \& gray WP

clay gray green

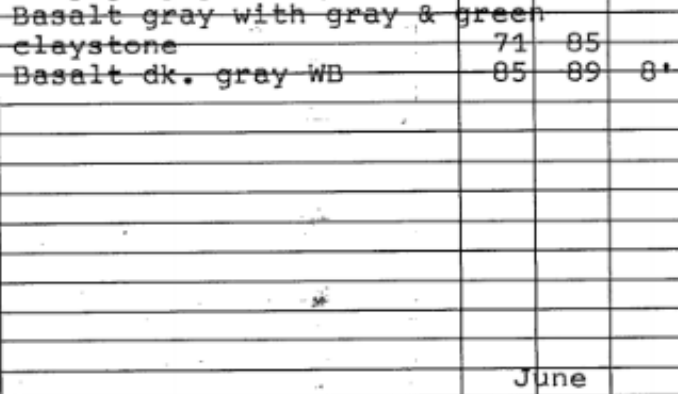

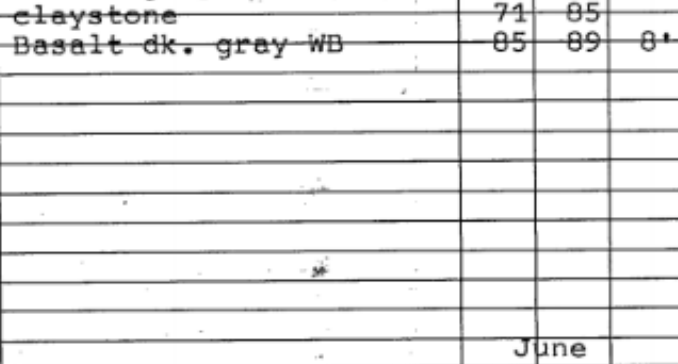

Date started 29 May 1987 Completed 4 foty 1987

(unbonded) Water Well Construetor Certification:

I certify that the work I performed on the construction, alteration, or abandonment of this well is in compliance with Oregon well construction atandards. Materials used and information reported above are true to my best knowledge and belief.

Signed wwC Number $\frac{69687}{19}$

(bonded) Water Well Construetor Certification:

I accept responsibility for the construction, alteration, or abandonment work performed on this well during the construction dates reported above. all work performed during this time is in compliance with Oregon well construction standards. This report is true to the best of my lenowledge and

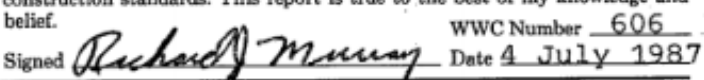




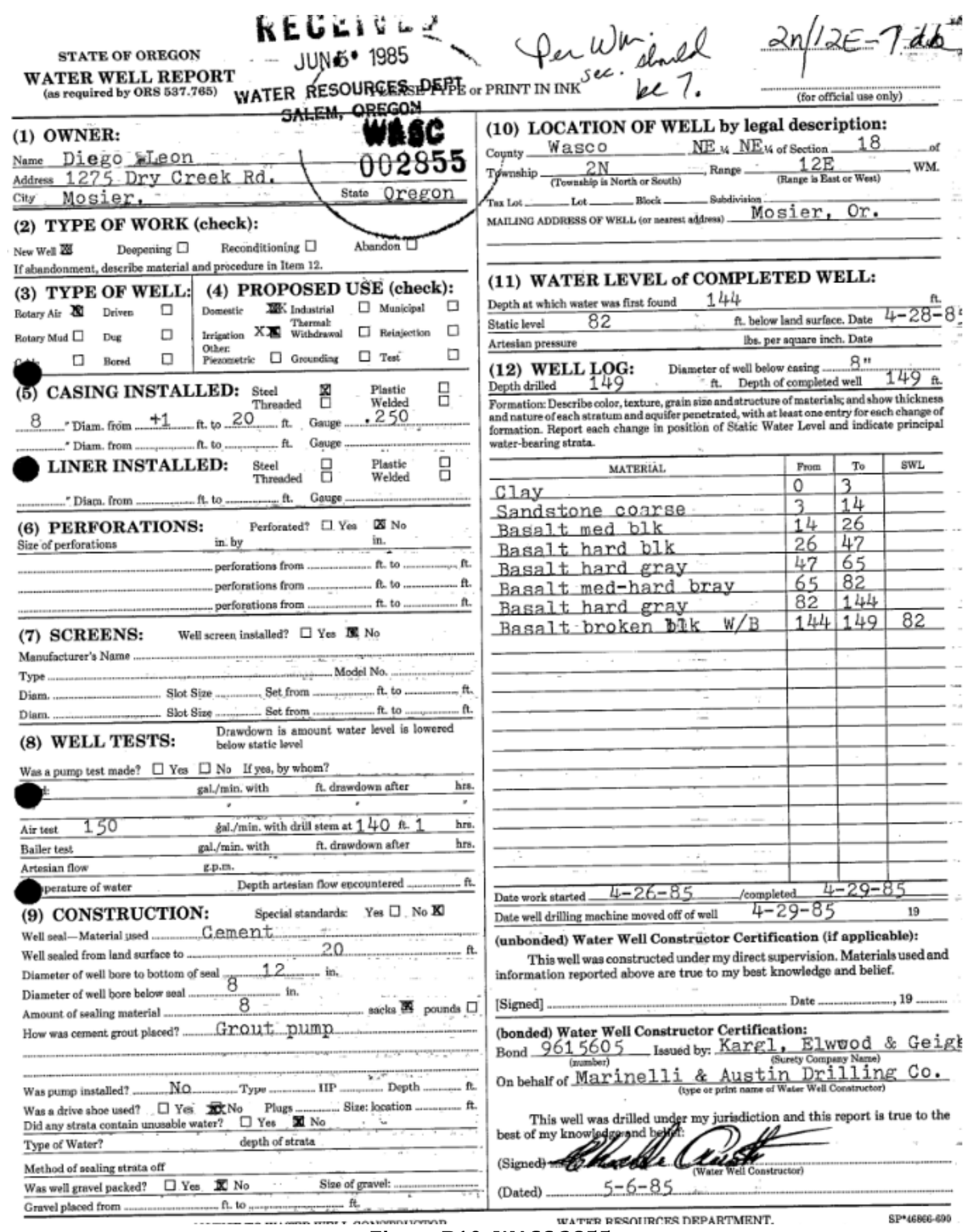

Figure B10: WASC 2855 


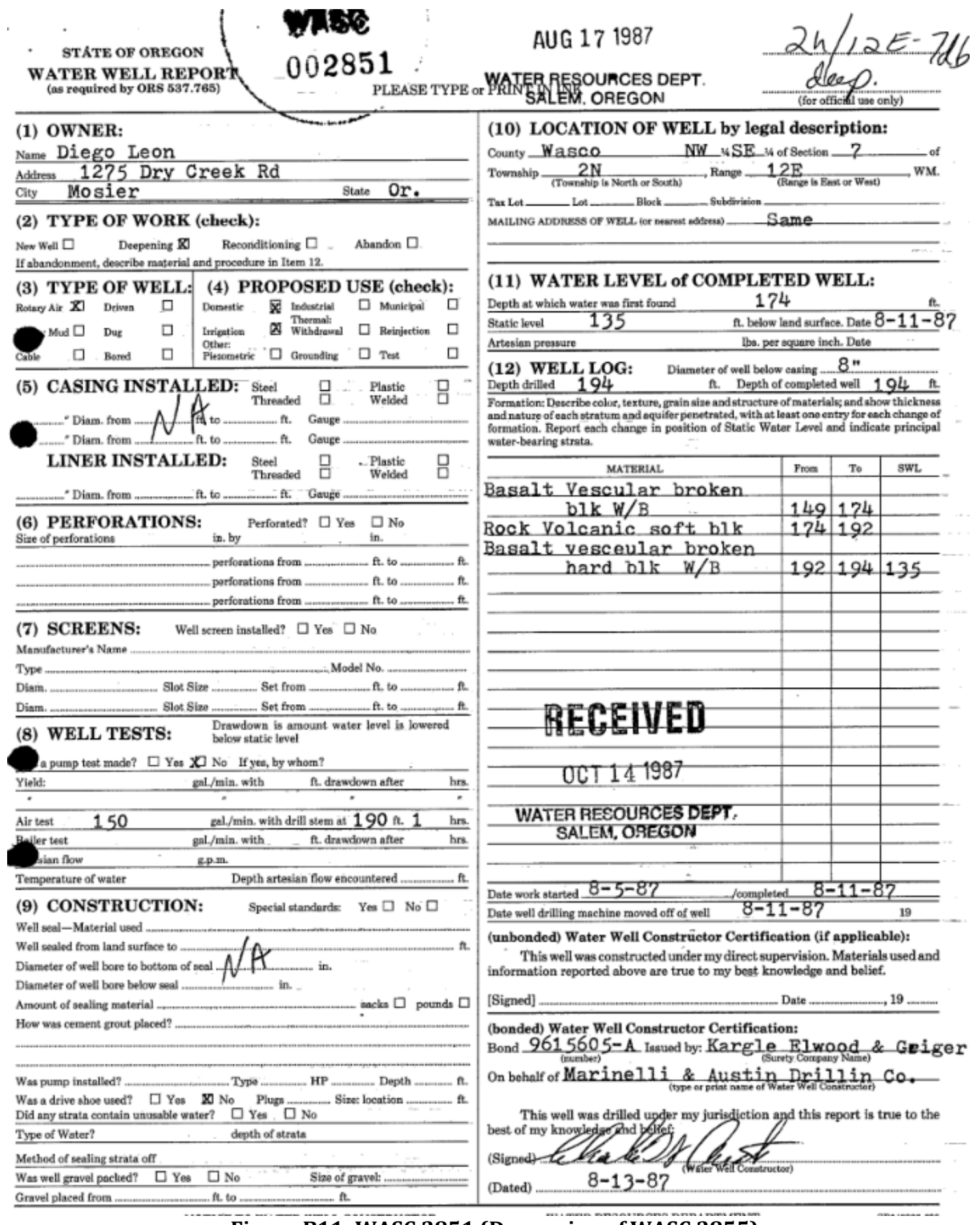

Figure B11: WASC 2851 (Deepening of WASC 2855) 


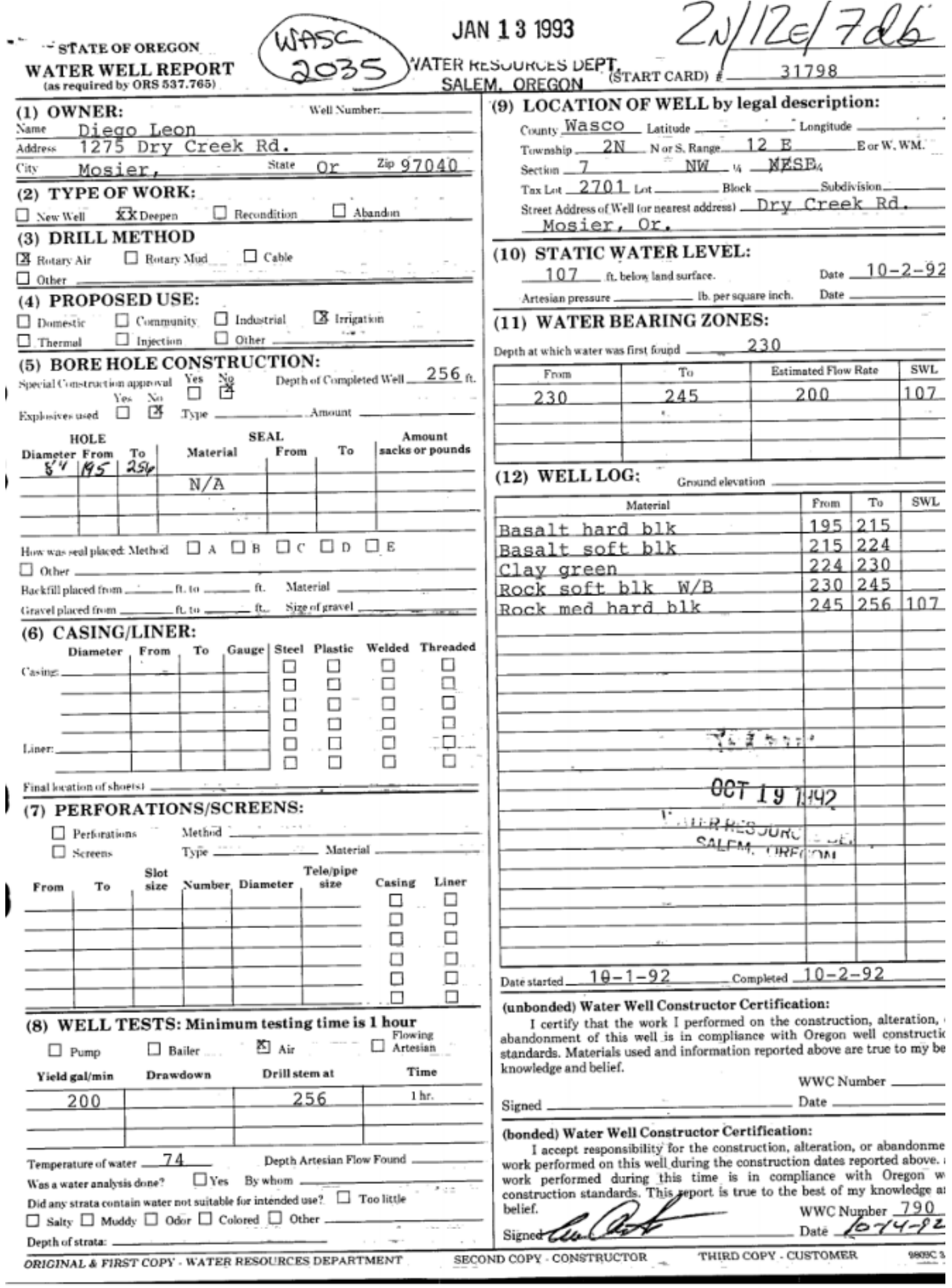

Figure B12: WASC 2035 (Second deepening of WASC 2855) 


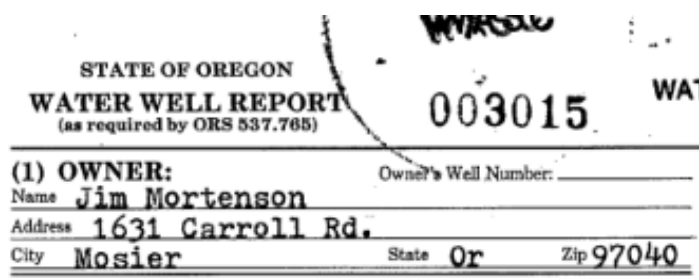
(2) TYPE OF WORK:

खew Well $\square_{\text {Deepen }} \square_{\text {Reconditton }} \square_{\text {Abendon }}$

(3) DRILL METHOD:

[ R Rotary Air $\square$ Rotary Mud $\square$ Cable $\quad \square$ other

(4) PROPOSED USE:

(x) Pomestic $\square$ Community $\square$ Induatrial ' $\square$ Irrieation

(5) BORE HOLE CONSTRUCTION

Depth of Completed Well _ 245

Special Standards date of approval

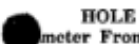
BEAL \begin{tabular}{c|l|l|l|l|l|l} 
& & & \multicolumn{2}{l}{ sacks or pounds } \\
\hline 10 & 0 & 25 & & & & \\
\hline 8 & 25 & 120 & Cement \& & Bent. 23 Bas Cem. \\
\hline
\end{tabular} \begin{tabular}{cc|cccc}
8 & 25 & 120 & Cement \& & Bent. & 23 \\
\hline 6 & 120 & 245 & 41 & 59 & 7 bas Cem. \\
\hline
\end{tabular} How was seal placod? Method $\quad \square_{\mathrm{A}} \quad \square_{\mathrm{B}}$ 冈 $\mathrm{C} \square \mathrm{D} \square_{\mathrm{B}}$ $\square$ other

Backifil placed from —— t. to —_ ft. Material Gravel placed from $\quad$ in. to _ $\quad$ i. Size of gravel.

(6) CASING/LINER:

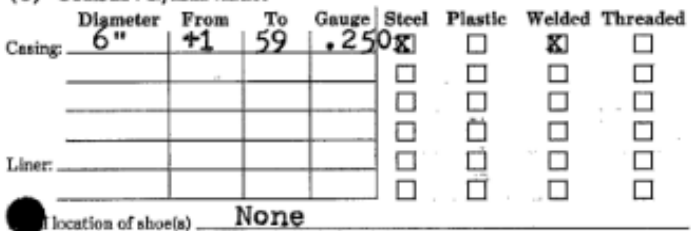

location of shoe(s) None

(7) PERFORATIONS/SCREENS:

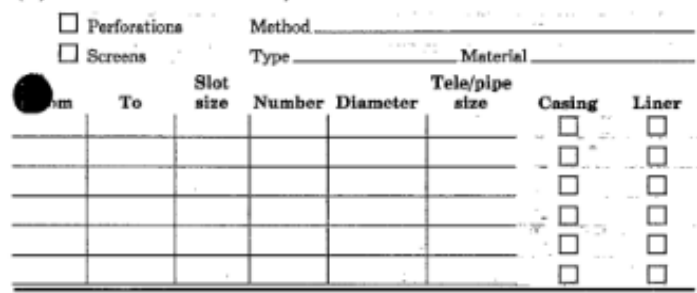

(8) WELL TESTS: Minimum testing time is 1 hour

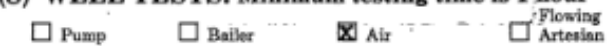
Yleld gal/min Pumping level Drill stem at Time

\begin{tabular}{c|c|c|c} 
Yleid zal/min Pumping level & Drill stem at & \multicolumn{1}{c}{ Time } \\
\hline 20 & & 240 & $1 \mathrm{hr}$ \\
\hline & & & \\
\hline & & & \\
\hline
\end{tabular}

Temperature of water ___ ...... Depth Arteslan Flow Found ___

Wea a water analysis done? $\square$ Yea. By whom

Did any strate contain water not suítable for intended use? $\square$ Too little

$\square$ Salty $\square$ Muddy $\square$ odor $\square$ colored $\square$ other

Depth of strata:
AUG 17 IYøI

WATER RESOURCES DEPT. SALEM, OREGON

(9) LOCATION OF WELL by legal deseription: County Wasco Latitude L Longitude $\frac{1}{12}$ Township $2 \mathrm{~N} \quad \mathrm{~N}$ or S. Range $12 \mathrm{E}$ E or W, WM

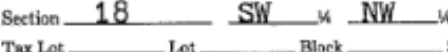
Street Address of Well (or nearest addresa) ___ same

(10) STATIC WATER LEVEL:

133 te. below land surfece.

Date 6-26-87:

Artesian pressure th. per square inch. Date (11) WELL LOG: Ground elevation

\begin{tabular}{|c|c|c|c|c|}
\hline Material & From & To & WB? & SWL \\
\hline Soll BIK & 0 & 3 & & \\
\hline Clay soft brown & 3 & 11 & & \\
\hline Sandstone hard brown & 11 & 20 & & \\
\hline clay brown & 20 & 42 & & \\
\hline Sandstone hard boown & 42 & 88 & & \\
\hline Sandstone with rocks & 88 & 93 & & \\
\hline Basalt hard grey & 93 & 145 & & \\
\hline Basalt hard grey & 145 & 212 & & \\
\hline Basalt hard blk & 212 & 241 & & \\
\hline Sandstone \& Clay br. & 241 & 245 & WB & 133 \\
\hline & 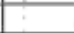 & & & \\
\hline 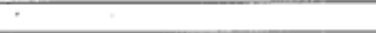 & & & & \\
\hline & 4 & & & \\
\hline & 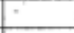 & & & \\
\hline & & & & \\
\hline & & & & \\
\hline & & & & \\
\hline & & & & \\
\hline- & & & & \\
\hline & . & & & . \\
\hline & & & & \\
\hline 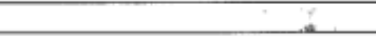 & & & & \\
\hline & 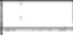 & & & \\
\hline & 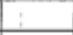 & & & \\
\hline & & & & \\
\hline$-z$ & $\therefore$ & & & \\
\hline+ & + & & & \\
\hline 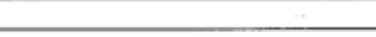 & + & & & \\
\hline 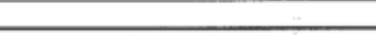 & + & & & \\
\hline
\end{tabular}

Date started 6-19-8? Completed 6-26-8?

(unbonded) Water Well Construetor Certification:

I constructed this well in complience with Oregon well construction standards. Materials used and information reported above are true to my best knowledge and belief.

Signed Date $6-30-87$

(bonded) Water Well Construetor Certification:

I accept responsibility for construction of this well and its compliance with all Oregon water well standards. This report is true to the best of my knowledge and belief.

Signed Marinelli \& Austin Drbluling Co.

Company 1 , hoecla $\mathrm{Co}$ Job No.

Figure B13: WASC 3015 


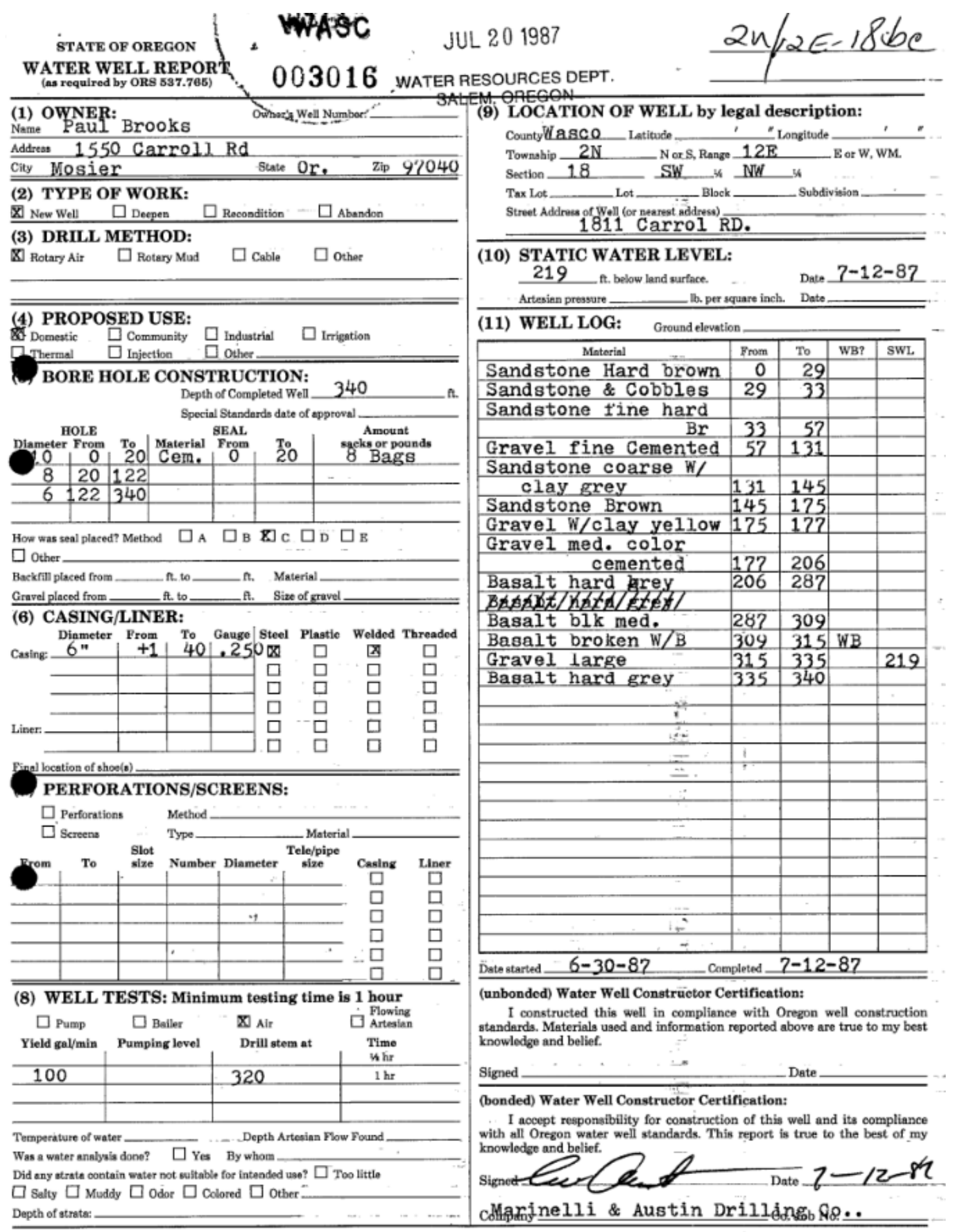

Figure B14: WASC 3016 


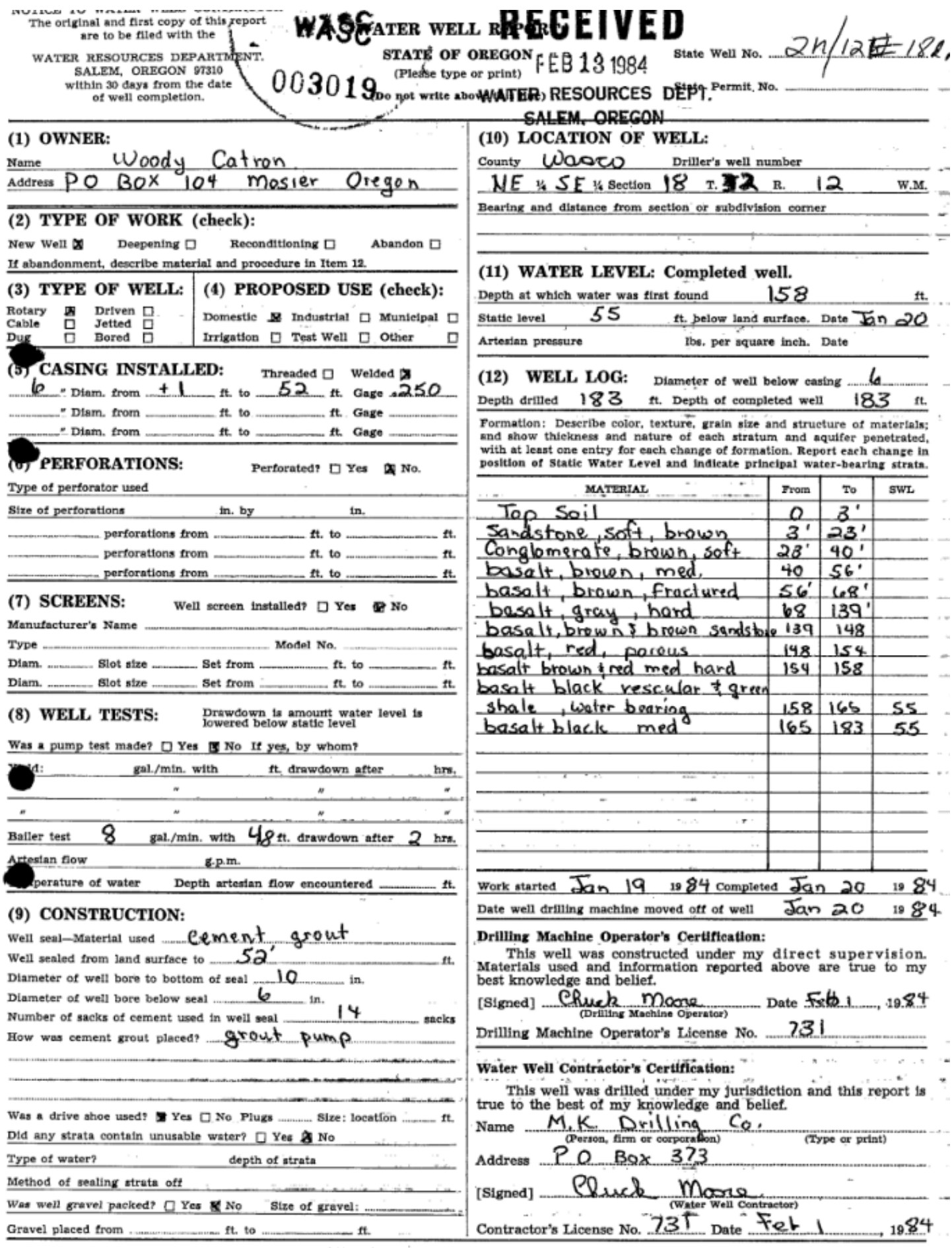

Figure B15: WASC 3019 


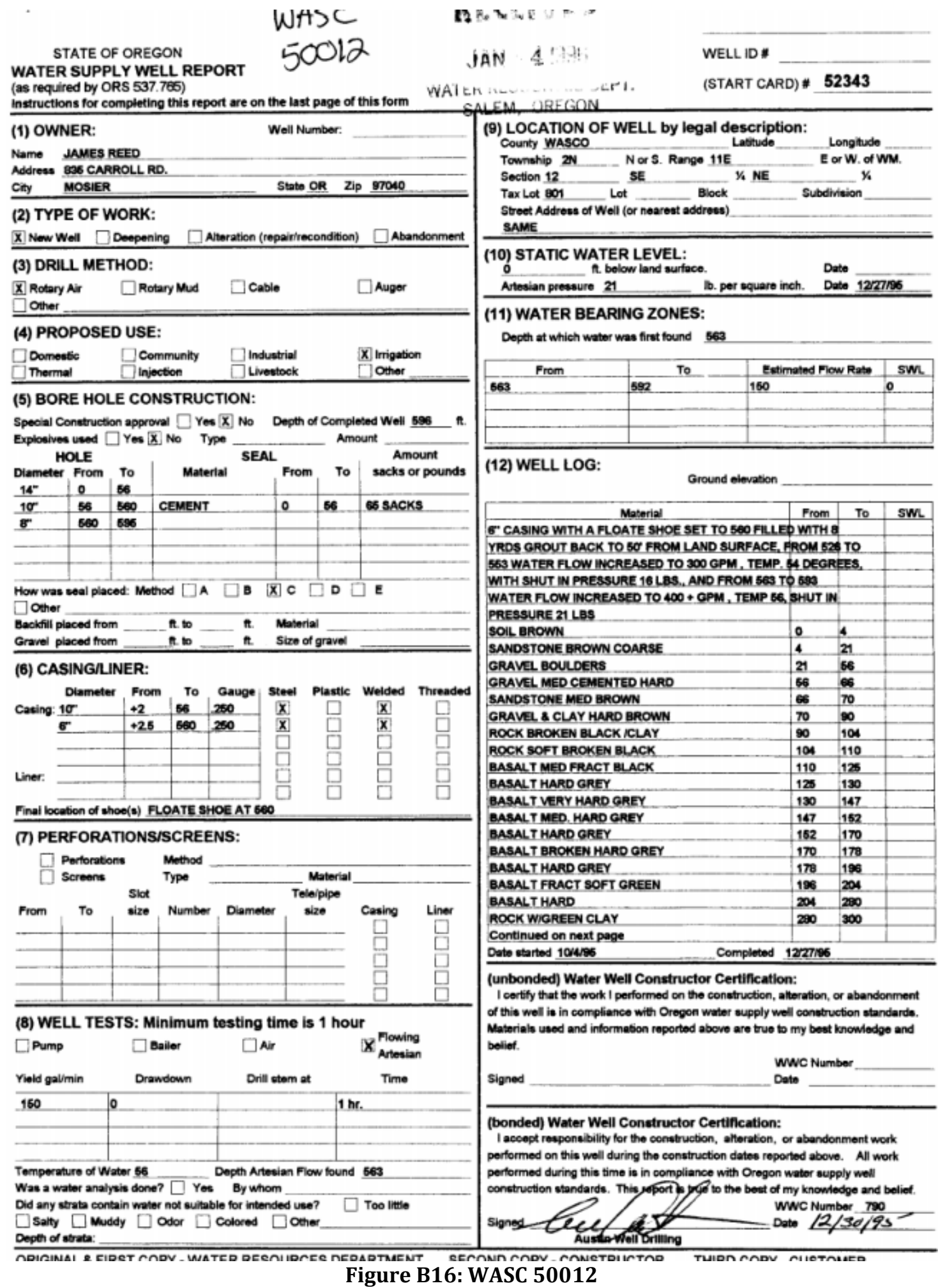


STATE OF OREGON

WATER SUPPLY WELL REPORT

(as required by ORS $537.7 \pm 5$ )

instructions for completing this report are on the last page of this form

(1) OWNER

Well Number

Name JAMES REED

Addrese

State -2

(2) TYPE OF WORK:

$\square$ New Well $\square$ Deepening $\square$ Alteration (repairfrecondition) $\square$ Abandonment

(3) DRILL METHOD:

\begin{tabular}{llll}
$\square$ Rotary Air $\quad \square$ Rotary Mud & $\square$ Cable & $\square$ Auger \\
$\square$ Other & & \\
\hline (4) PROPOSED USE: & & \\
$\square$ Domestic $\quad \square$ Community & $\square$ Industrial & $\square$ irrigation \\
$\square$ Thermal & $\square$ Injection & $\square$ Livestock & $\square$ Other \\
\hline
\end{tabular}

(5) BORE HOLE CONSTRUCTION:

Special Conatruction approval $\square$ Yes $\square$ No Depth of Completed Woil ___ ${ }^{\text {th }}$ Exploeives uned $\square$ Yes $\square$ No Type

$$
\text { HOLE }
$$

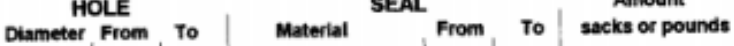
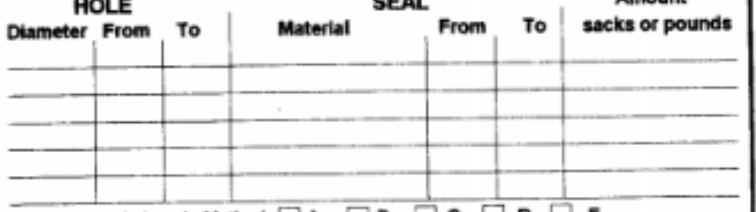

How was seal placed: Method $\square$ A $\square$ B $\square$ C $\square$ D $\square$ E

Beckfill placed from it. to n in. Material

Gravel placed from in to $n$. Size of gravel

(6) CASINGILINER:

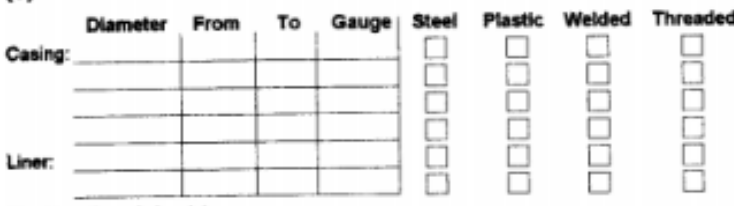

Final location of shoe(s)

(7) PERFORATIONS/SCREENS:

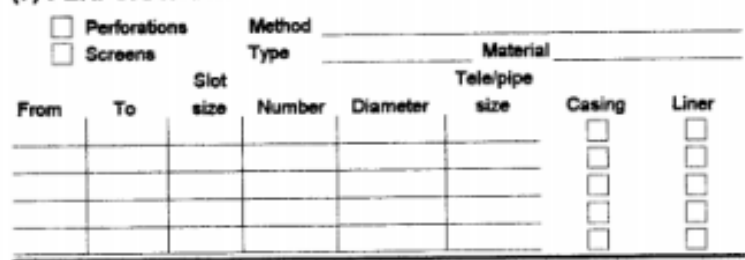

(8) WELL TESTS: Minimum testing time is 1 hour
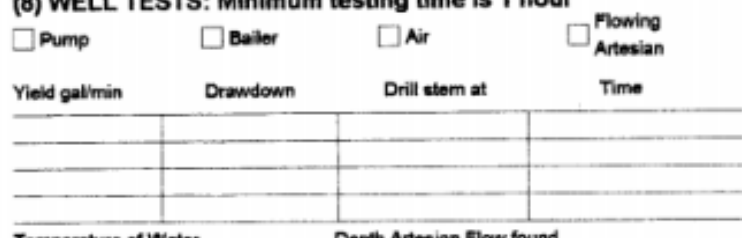

Temperature of Water

Depth Artesian Flow found

Was a water analysis done? $\square$ Yes By whom

Did any strata contain water not wuitable for intended uee? $\square$ Too litte

Depth of etrata:
WELL ID* $\quad \mathbf{5 2 3 4 3}$

(START CARD) \#

Page 2

SALEM, UREGON

Utr.

(9) LOCATION OF WELL by legal description:

County ___ Latitude__Longitude Township ZN Nor S. Range 11E E or W. of WM. Section 12

Tax Lot Lot Block__ Subdivision

Street Address of Well (or nearest address)

\begin{tabular}{|c|c|c|}
\hline (10) STATIC WATER LEVEL: & & Date \\
\hline Nitesian pressure & lb. per square inch. & Date \\
\hline
\end{tabular}

(11) WATER BEARING ZONES:

Depth at which water was first found

\begin{tabular}{|l|l|l|l|}
\hline From & To & Estimated Plow Rate & SWL \\
\hline & & & \\
\hline & & & \\
\hline & & & \\
\hline
\end{tabular}

(12) WELL LOG:

Ground elevation

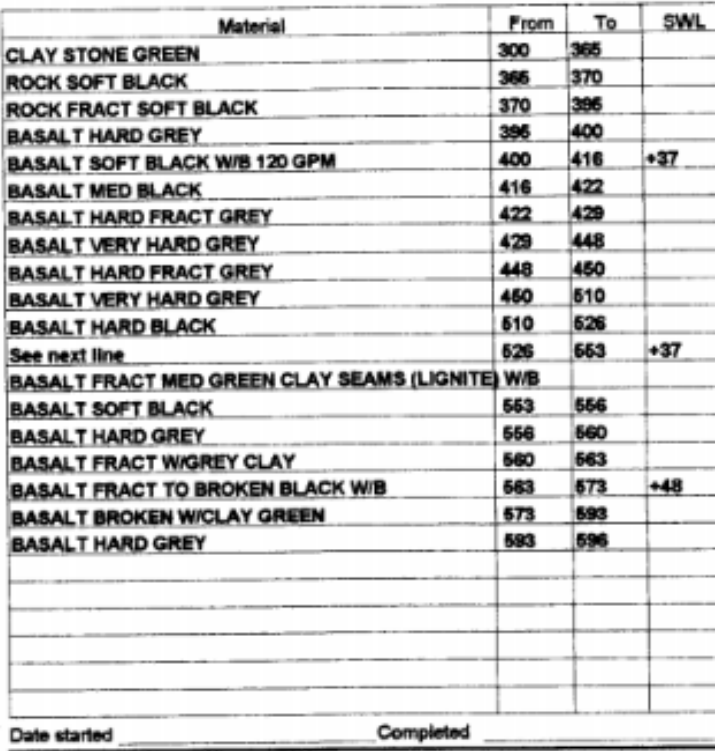

(unbonded) Water Well Constructor Certification:

I oertify that the work I performed on the construction, alteration, or abandonment of this woll is in compliance with Oregon water supply well construction standards Materials used and information reported above are true to my best knowledge and beliet.

Signed

wwc Number Dato

(bonded) Water Well Constructor Certiflcation:

I accept responsibility for the construction, alteration, $\propto$ abandonment work performed on this well during the conetruction dates reported above. All work performed during this time is in compliance with Oregon water supply well construction standards. This report is true to the best of $m y$ knowledge and beliet.

Signed WWC Number 790 Dato Austin Well Drilling

Figure B17: WASC 50012 page 2 


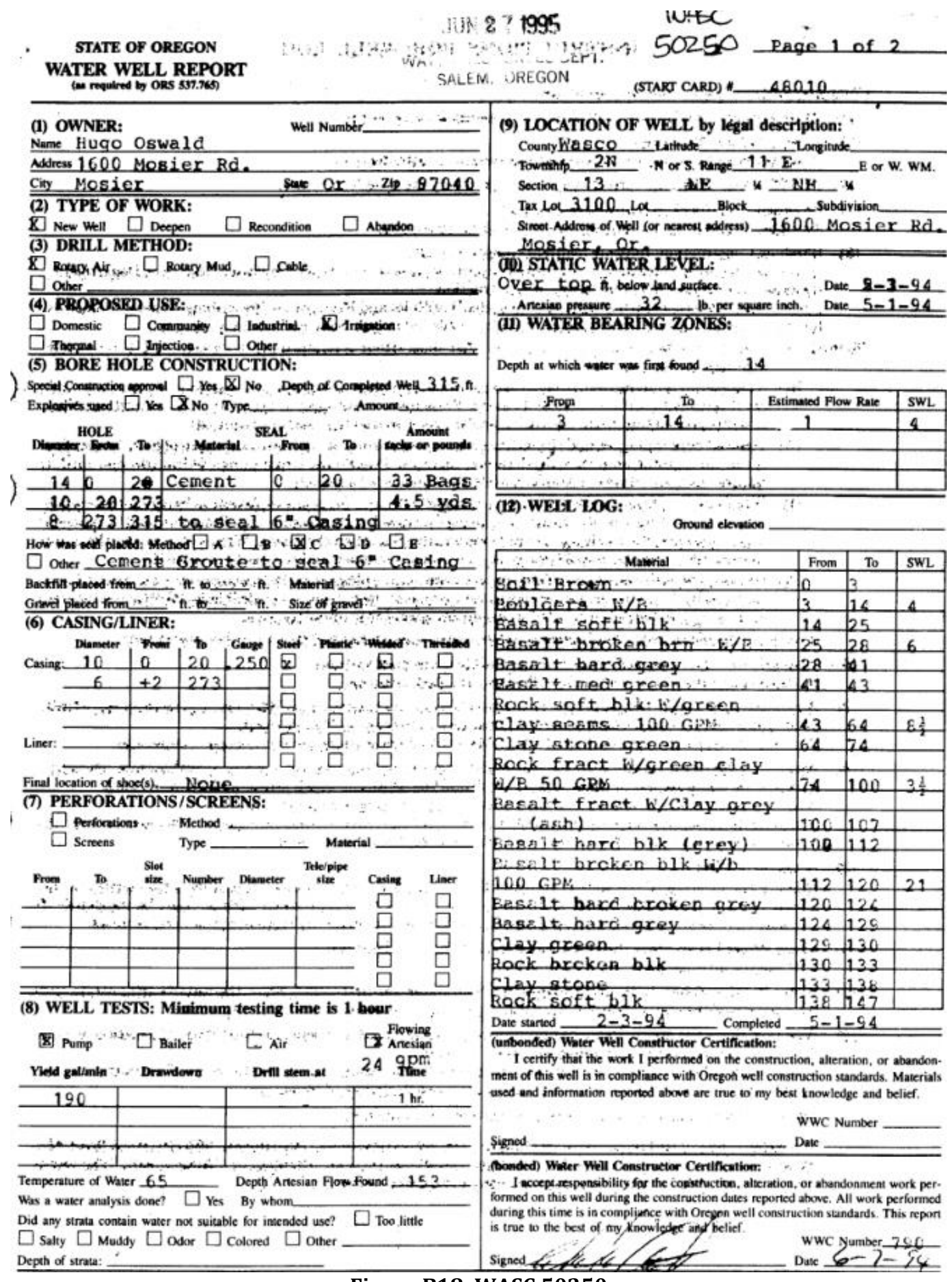

Figure B18: WASC 50250 


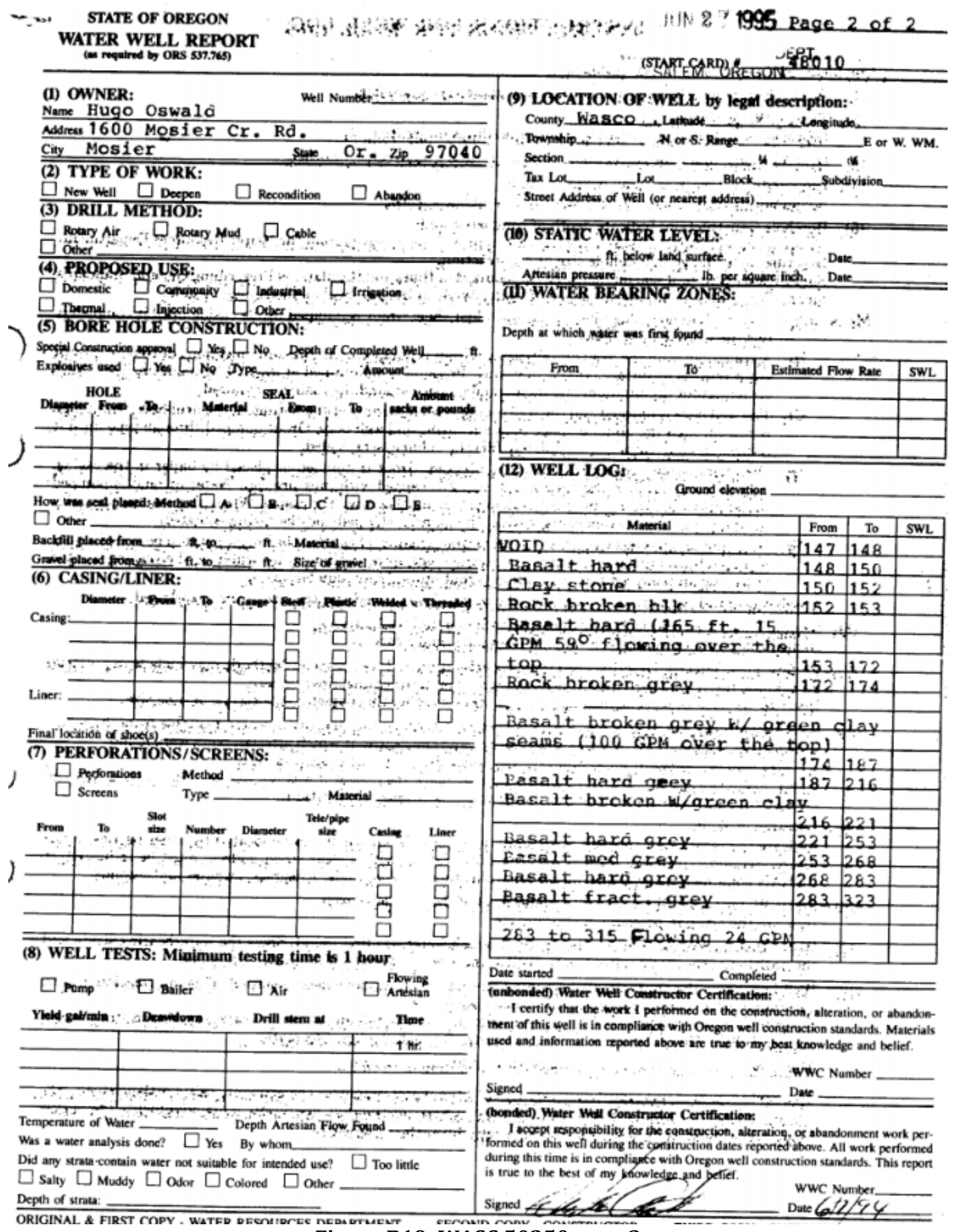

Figure B19: WASC 50250 page 2 


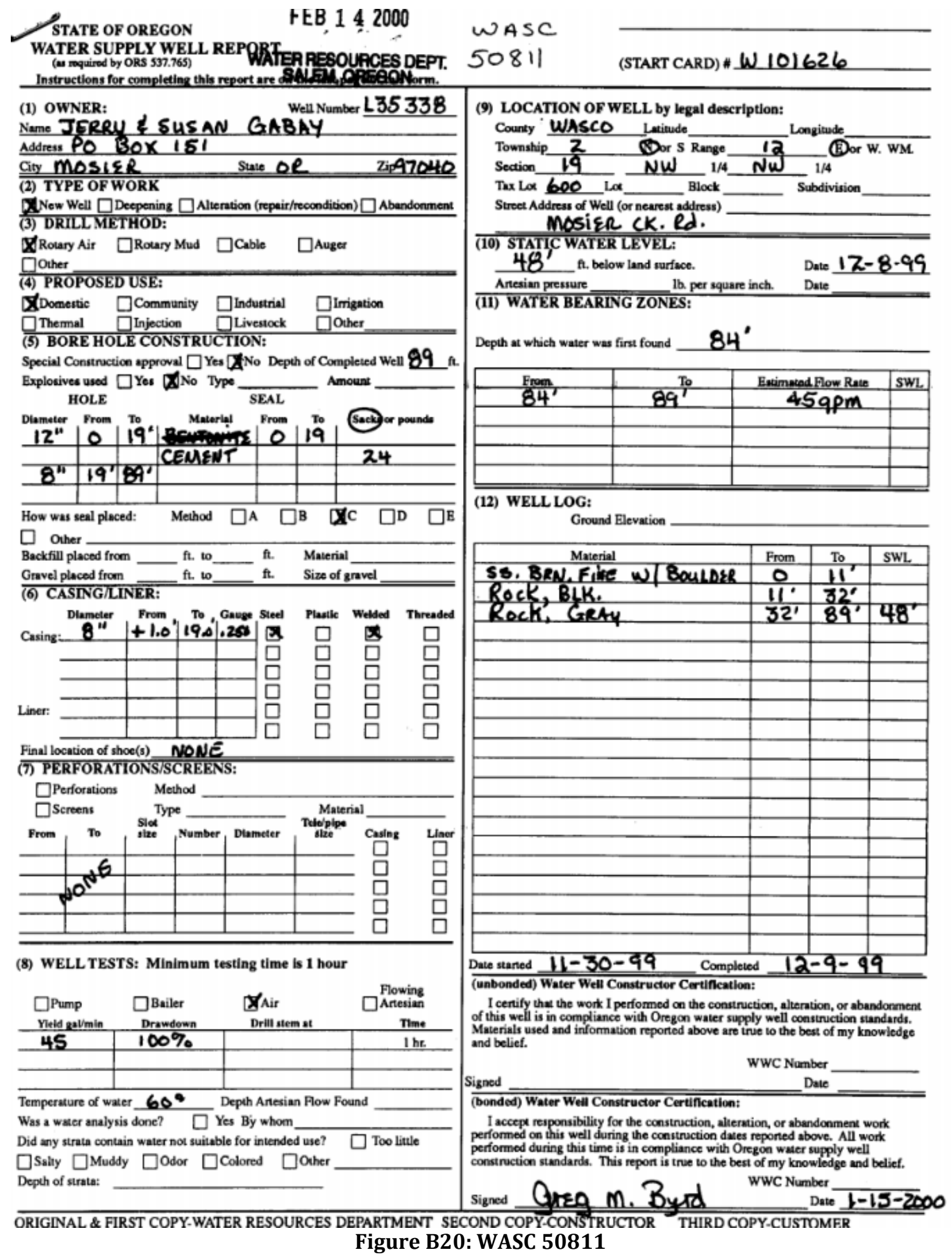




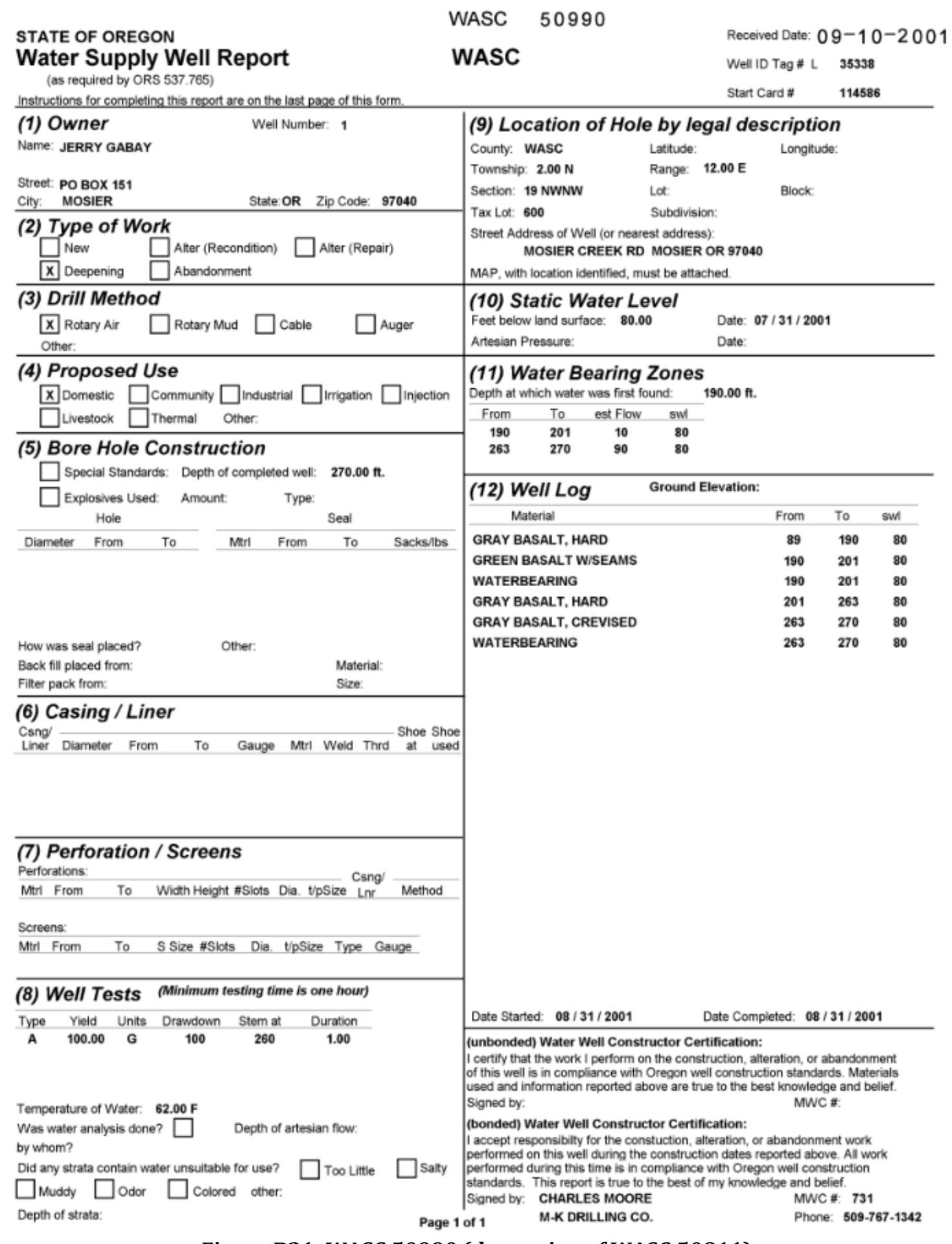

Figure B21: WASC 50990 (deepening of WASC 50811) 


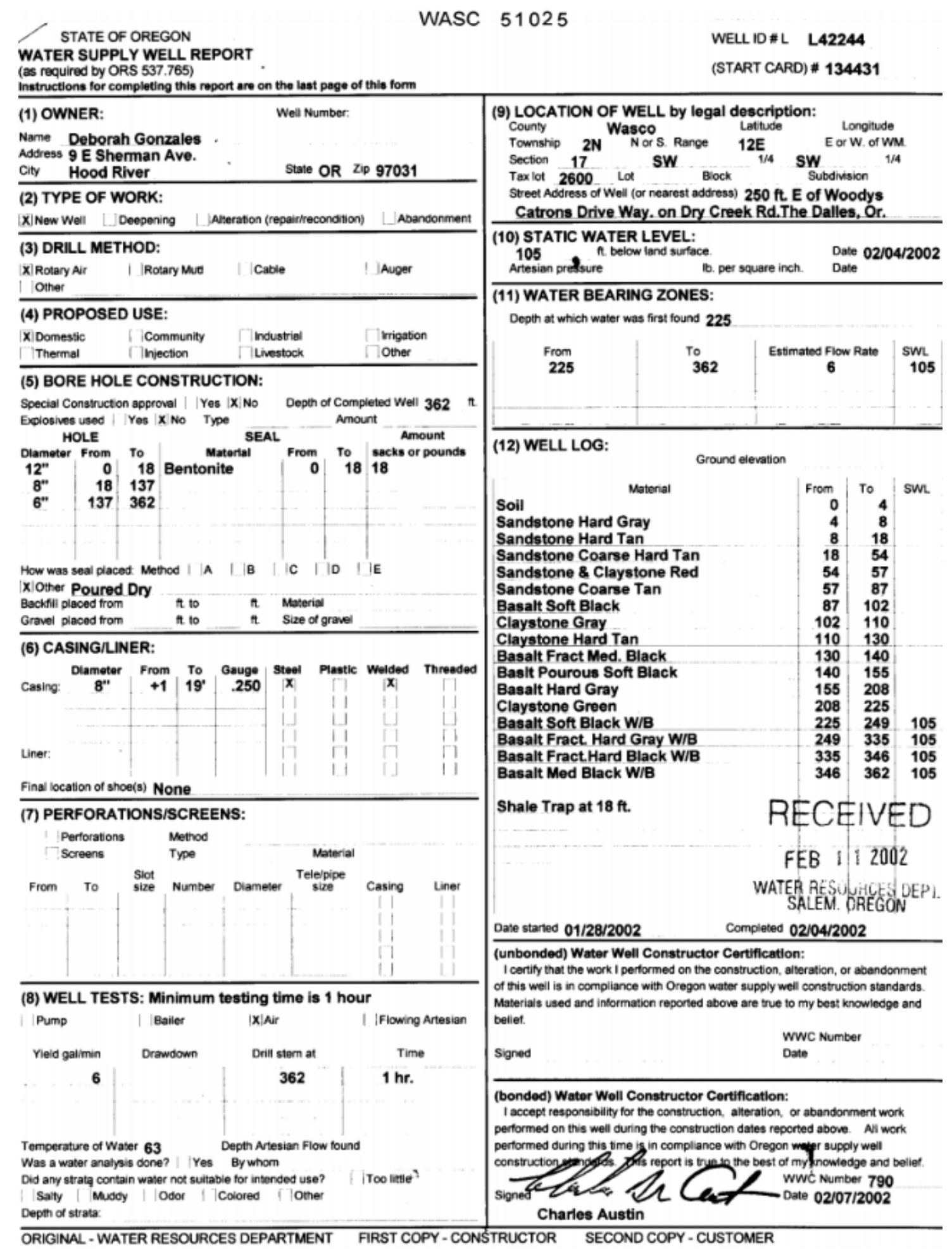

Figure B22: WASC 51025 
STATE OF OREGON

WATER SUPPLY WELL REPORT

(as required by ORS 537.765)

Instructions for completing this repart are en the last page of this form.

\begin{tabular}{|c|c|c|}
\hline $\begin{array}{l}\text { (1) L.AND OWNER } \\
\text { Name PAUL J CITOU }\end{array}$ & \multicolumn{2}{|c|}{ Well Number 1} \\
\hline \multicolumn{3}{|l|}{ Addrons: 12438 68TH AVE NE } \\
\hline City KIRKLAND & State WA & Zo 98034 \\
\hline $\begin{array}{l}\text { (2) TYPE OF WORK } \\
\square \text { Doepening } \square \text { Alteration (rep }\end{array}$ & $\begin{array}{l}\text { New Well } \\
\text { rirecondition) }\end{array}$ & Abandonment $\square$ Coeversion \\
\hline \multicolumn{3}{|c|}{$\begin{array}{l}\text { (3) DRILL METHOD } \\
\text { Rotary Air } \square \text { Rotary Mud } \square \text { Cable } \square \text { Aager } \square \text { Cable Mad } \\
\square \text { Other }\end{array}$} \\
\hline $\begin{array}{l}\text { (4) PROPOSED USE } \\
\square \text { Demestic } \square \text { Conmunity } \\
\square \text { Thermal } \quad \square \text { Injoction }\end{array}$ & $\begin{array}{l}\square \text { Industrial } \\
\square \text { Livestock }\end{array}$ & $\begin{array}{l}\square \text { Imigation } \\
\square \text { other }\end{array}$ \\
\hline
\end{tabular}

(5) BORE HOLE CONSTRUCTION Special Constractioe: $\square$ Yen $\square$ No Depth of Completad Well 520

Explosives ued: $\square$ Yes $\bar{\square}$ No Typo___ Amount BORE HOLE

\begin{tabular}{|c|c|c|c|c|c|c|}
\hline \multicolumn{3}{|c|}{ BOKE HOL } & \\
\hline $\begin{array}{l}\text { Dinmeter } \\
10^{*}\end{array}$ & $0^{\text {From }}$ & ${ }_{139}^{T o}$ & $\begin{array}{l}\text { Material } \\
\text { CE }\end{array}$ & $\begin{array}{l}\text { Fraen } \\
10\end{array}$ & $\begin{array}{r}\text { To } \\
139\end{array}$ & $\begin{array}{l}\text { Sacks or Pounds } \\
\text { |32 SACKS }\end{array}$ \\
\hline $10^{\circ}$ & 0 & 139 & BE & 0 & 10 & 5 SACKS \\
\hline $6^{\prime \prime}$ & 139 & 520 & & & & \\
\hline
\end{tabular}

How was seal placed: Method $\square$ A $\square$ B $\square$ C $\square D \quad \square E$

Dother

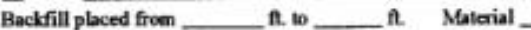

Grovel placed from _

(6) CASING/LINER

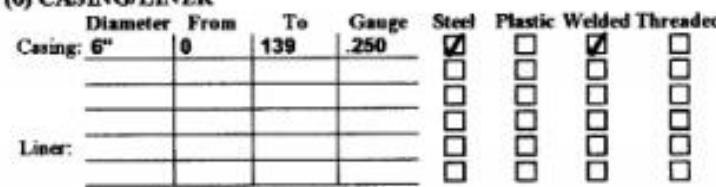

Drive Shee used $\square$ Ianide $\square$ Outside $\square$ None

Final location of stoo(s)

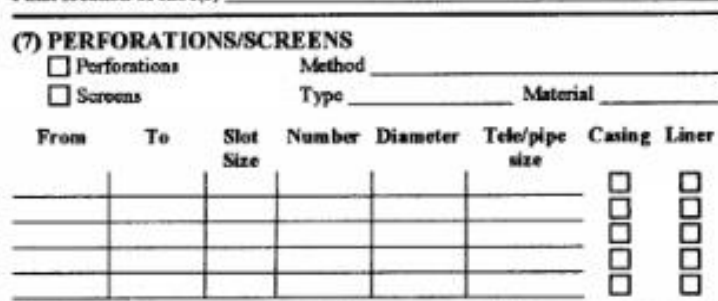

(8) WELL TESTS: Minimum testing time is 1 hour

$\square$ Puap $\square$ Bailer $\square$ Air $\square$ Flowing Artesisa

\begin{tabular}{|c|c|c|c|}
\hline $10^{\text {Yield gal/min }}$ & $\begin{array}{l}\text { Drawdewn } \\
100\end{array}$ & $\mathrm{~s}_{500}^{\text {Driti stem at }}$ & 1 HR \\
\hline & & & \\
\hline
\end{tabular}

Temperature of water 60 Depth Artesian Flow Foun

Was a water analysis done? $\square$ Yos By whom

Did any strata contain water not suitable for imended uec?

$\square$ Salty $\square$ Muddy $\square$ Odor $\square$ Colored $\square$ Other

Depeth of strata
WELL. L.D. \# L, 74090

START CARD * W169797

9) LOCATION OF WEL.L. (legal description)

County WASCO

Tax Let 2501 Lot

Townahip 2 R $N$ Range $12 \quad$ E

Section 17 SW $1 / 4$ SW

Lat _- or _______ (degrees or docimal)

long (degrees or decimal)

Stred Address of Well (or nearat addreas) DRY CREEK RD MOSIER OR 97040

\begin{tabular}{|c|c|}
\hline $\begin{array}{l}\text { (10) STATIC WATER LEVEL } \\
410\end{array}$ & Date $06-08-05$ \\
\hline f. bolow land surface. & Date \\
\hline Artesian prossure ___ ib. per square inch & Date_ \\
\hline
\end{tabular}

(11) WATER BEARING ZONES

Depth at which water was fint found 488

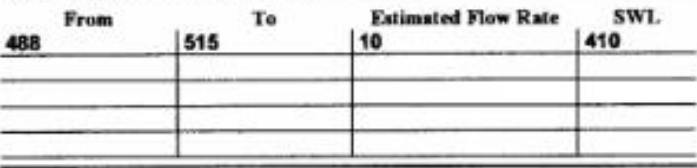

(12) WELL LOG Ground Flevation

Topsol Material 10 From $0^{\text {To }}$ SwL.

BOULDERS \& CLAY

GRAY 8 BROWN BASALT, MILO

FRACTURES

GRAY BASALT, MED HARD

BROWN BASALT, WEATHERED

GRAY BASALT WIBLUE SEAMS

BLACK \& BLUE CLAY

BLACK BASALT, MEDIUM

GRAY BASALT, MED HARD

GRAY, BROWN \& BLUE BASALT

MEDIUM

GRAY BASALT MED HARD

GRAY BASALT, HARD

GRAYBBROWN BASALT,PORUS

BLUE CLAYSTONE

Date Started 06-02-05

\begin{tabular}{|c|c|c|}
\hline From & To & SWL. \\
\hline 0 & 1 & \\
\hline 1 & 4 & \\
\hline 4 & 14 & \\
\hline 4 & 14 & \\
\hline 14 & 87 & \\
\hline 87 & 97 & \\
\hline 97 & 108 & \\
\hline 108 & 119 & \\
\hline 119 & 146 & \\
\hline 146 & 169 & \\
\hline 169 & 176 & \\
\hline 169 & 176 & \\
\hline 176 & 210 & \\
\hline 210 & 282 & \\
\hline 282 & 303 & \\
\hline 303 & 315 & \\
\hline
\end{tabular}

(unboeded) Water Well Constructor Certification

I certify that the work 1 performed on the constraction, dexpening, alteration of abandonment of this well is in compliance with Oregon water supply well constructicn standards. Materials uecd and information reportod above are tree to the beat of my kaowledge and belief

wwe Number 1833

Date 06-09-05

\section{signed Crise $42 \mathrm{Cr}$}

(bonded) Water Wel Constructor Certification

I accept responsibility for the construction, decpening alieration, of absadonment work performed on this well during the conatruction dates reporked above. All work performed during this time is in compliance with Oregon water supply well construction stasdards. This report is true to the best of any knowledg and belief

WwC Number 73

Date 06-09-05

signad Charles of N120 12 
STATE OF OREGON

WATER SUPPLY WELL REPORT

(at required by ORS 537.765)

Instructions for completing this repert are on the last page of this form.

\begin{tabular}{|c|c|c|}
\hline $\begin{array}{l}\text { (1) LAND OWNER } \\
\text { Name PAUL J CITOU }\end{array}$ & Well $\mathrm{Nu}$ & lumber 1 \\
\hline \multicolumn{3}{|l|}{ Addras $1243868 T H$ AVE NE } \\
\hline City KRKLAND & Sutc WA & $Z_{0} 98034$ \\
\hline $\begin{array}{l}\text { (2) TYPE OF WORK } \\
\square \text { Deepening } \square \text { Alteration (nep }\end{array}$ & $\begin{array}{l}\text { Z New Well } \\
\text { irfireconditioa) }\end{array}$ & Abandenment $\square$ Convenion \\
\hline $\begin{array}{l}\text { (3) DRILL METHOD } \\
\text { Rotary Air } \square \text { Rotary Mod } \\
\square \text { other }\end{array}$ & Cable $\square$ Aager & a Cable Mad \\
\hline $\begin{array}{l}\text { (4) PROPOSED USE } \\
\text { OD Domeatic } \\
\square \text { Thamal } \\
\square \text { Injoction }\end{array}$ & $\begin{array}{l}\square \text { Industrial } \\
\square \text { Livestock }\end{array}$ & $\begin{array}{l}\text { DIrrigation } \\
\square \text { other. }\end{array}$ \\
\hline
\end{tabular}

(5) BORE HOLE CONSTRUCTION Spocial Construction: $\square$ Ya $\square$ No Depth of Completod Well 520

Explosives uned: $\square$ Yes $\bar{\nabla}$ No Type ___ Amount BORE HOLE

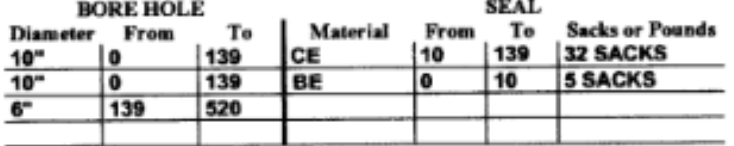

How was seal placed: Mechod $\square$ A $\square$ B ØC $\square \mathrm{D} \quad \square \mathrm{E}$

$\square$ Other

Backffill plecod from ft. to ft. Material Gravel placed from __

(6) CASING/LINER

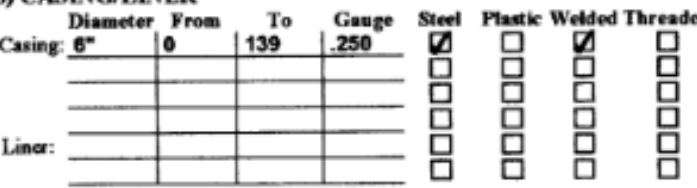

Drive Shoe unod $\square$ Inside $\square$ Outside $\square$ None

Final location of thoo(s)

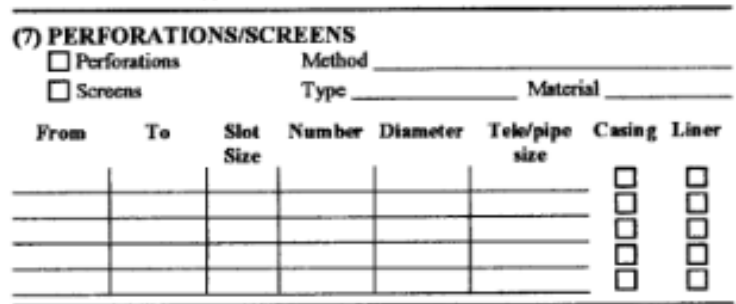

(b) WELL TESTS: Minimum testing time is 1 hour

$\square$ Pamp $\square$ Bailer $\square$ Nir $\square$ Flowing Artesias

\begin{tabular}{|c|c|c|c|}
\hline${ }_{10}^{\text {Yield gal/min }}$ & $\begin{array}{l}\text { Drawdown } \\
100 \\
\end{array}$ & $\mathrm{so0}^{\text {Drill stem at }}$ & 1 HR ${ }^{\text {Time }}$ \\
\hline & & & \\
\hline
\end{tabular}

Temperature of water $60 \quad$ Deph Artesian Flow Found

Was a water analyaia done? $\square$ Ye By whom

Did any strata contain water not suitable for intended use?

$\square$ Salty $\square$ Muddy $\square$ odor $\square$ Colored $\square$ other

Depth of strata:
WELI. LD. \# L 74090

START CARD \# W169797

(9) LOCATION OF WELL (legal description)
County WASCO
Tax Lot 2501
Township 2
Soction 17
tat
Long

Strect Address of Well (or nearest addresa) DRY CREEK RD MOSIER OR 97040

(10) STATIC WATER LEVEI

410 ft. below land surface. Date 06-08-05

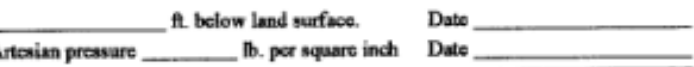

(11) WATER BEARING ZONES

Dopth at which water was finst found 488

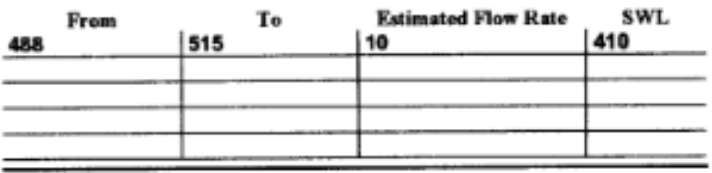

\begin{tabular}{cccc}
\hline $\begin{array}{c}\text { (12) WELL LOG } \\
\text { Material }\end{array}$ & Ground Elevation & & \\
\cline { 2 - 4 } & From & To & sWL
\end{tabular}

\begin{tabular}{l|l|l|l}
\multicolumn{1}{c|}{ Material } & & & \\
\hline GRAY BASALT WWWOOD & 315 & 326 & \\
\hline GRAY BASALT, MED HARD & 326 & 370 & \\
\hline GRAY BASALT, HARD & 370 & 425 & 410 \\
\hline GRAY \& BLACK BASALT,PORUS & 425 & 449 & 410 \\
\hline GRAY BASALT, MED HARD & 449 & 488 & 410 \\
\hline GRAY BASALT, CREVICED, WB & 488 & 515 & 410 \\
\hline GRAY BASALT, HARD & 515 & 520 & 410 \\
\hline & & & \\
\hline & & & \\
\hline & & & \\
\hline & & & \\
\hline & & & \\
\hline & & &
\end{tabular}

Date Started 06-02-05 Comploted 06-08-05

(unbonded) Water Well Coastructor Certificatio

I certify that the work I performod on the construction, deepening, alteration, on abandonment of this well is in compliance with Oregon water supply well

cosstruction standards. Materials used and information reported above are true to the beat of ay knuwledge and beliof.

wwC Number 1833 Date 06-09-05

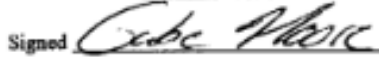

(bended) Water Well Constructer Certification

I accept reeponsibility for the oonstruction, deepening alteration, or abandosmeat work performed on this well during the construction dates reported above. All work performed during this time is in compliance with Oregon water supply well coastruction standarda. This report is true to the best of my knowlodgr and belief.

WwC Number 731 Date 06-09-05

Signedharleo of 14402 
STSTE OF OREGON

WATER SUPPLY WELL REPORT (as required by ORS 537.765 \& OAR 690-205-0210)

WELLLABEL L L 66330
START CARD $=175038$

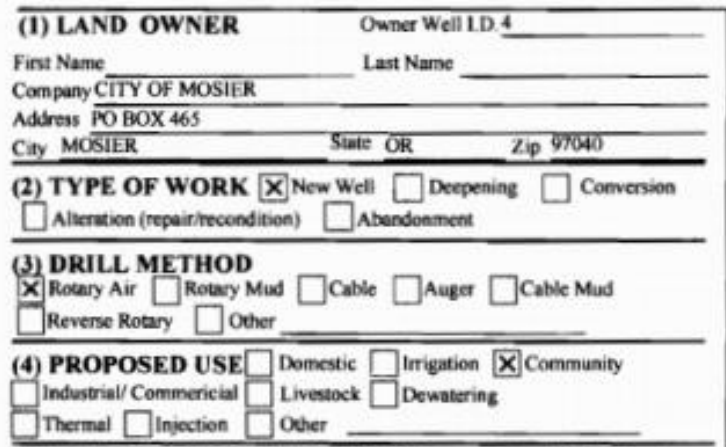

(5) BORE HOLE CONSTRUCTION Special Standerd DArtach cops

Depth of Completed Well 498

BORE HOLE
\begin{tabular}{|c|c|c|}
\hline Din & From & To \\
\hline 17.5 & 0 & 103 \\
\hline 12 & 105 & 285 \\
\hline 8 & 285 & 495 \\
\hline 5.25 & 495 & 498 \\
\hline
\end{tabular}

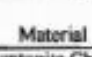
i. SEAL. Matcrial From To Amt liss \begin{tabular}{|l|c|c|c|c|}
\hline Cennent & 0 & 55 & 15 & 5 \\
\hline
\end{tabular} How was seal placed. Method cent

Tother

Backnil placed from

Filter pack from Method

\begin{tabular}{l|l|l|l}
\hline 785 & 285 & 256 & 5 \\
\hline
\end{tabular}

Explosives usad

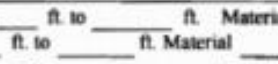
c $\square \mathrm{D} \square$ (6) CASING/LINER

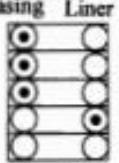

Type

-
Amount

\begin{tabular}{|c|c|c|c|}
\hline+ & From & To & Gauge \\
\hline & 0 & 9.5 & 375 \\
\hline & 0 & 105 & 375 \\
\hline 8 & 15 & 285 & 250 \\
\hline & 274 & 495 & 250 \\
\hline
\end{tabular}

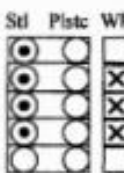

Shee $\square$ Inside $\square$ Outside $\square$ Other Location of shoc(s)

Temp casing $\square$ Yes Dia From

(7) PERFORATIONS/SCREENS

Perforations Method factory cut Screens Type

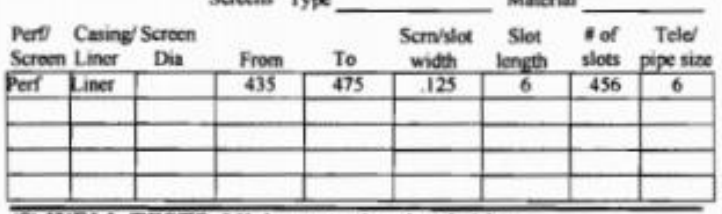

(8) WELL TESTS: Minimum teating time is 1 hour
Pump
Baile
- Air
Flowing Artesiar

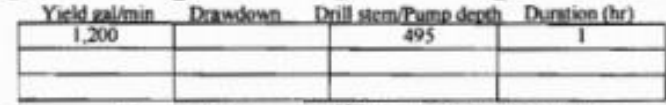

Temperature 59 "F Lab analysis X Yes By Mark Yinger \& Asso Water quality concerns? $\square$ Yes (describe below)

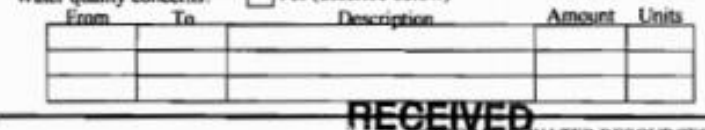

AEGEAREP

Figure B25: WASC 51497 Size

sise
- Te

\section{(9) LOCATION OF WEL.L (legal deseription)}

County WASCO Twp $2 \quad \mathrm{~N}$ N/S Rangell E EWWM $\mathrm{Sec} 12$ NE $1 / 4$ of the $\mathrm{NE}$ Tax Map Number

$1 / 4$ Tax Let 400

Lot

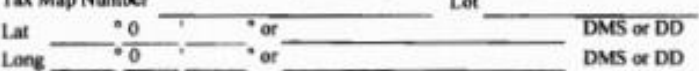

C. Street address of well $C$ Nearest address

951 MOSIER CREEK RD

(10) STATIC WATER LEVEL

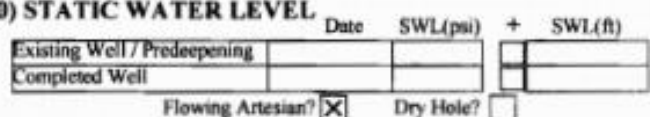

Flowing Artesian? $X \quad$ Dry Hole?

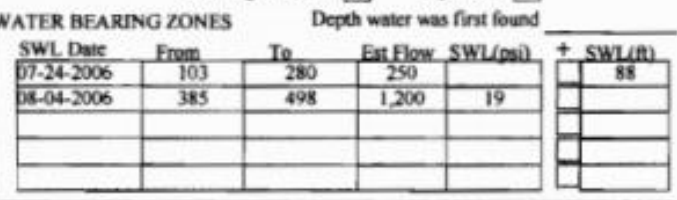

(11) WELL LOG Ground Elevation

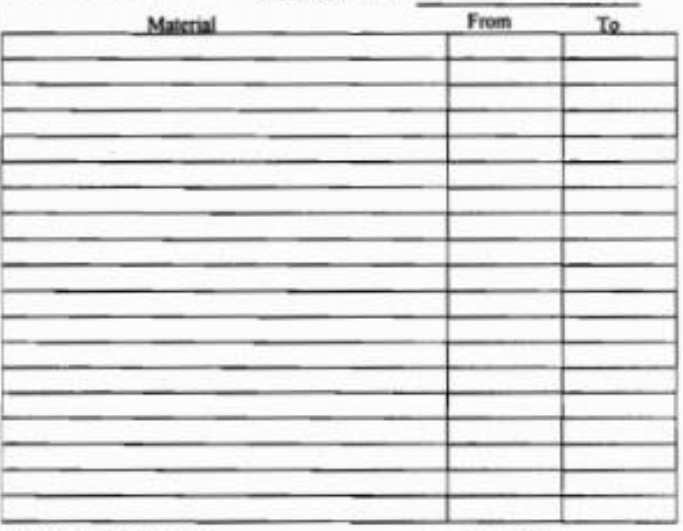

Date Staned 07-10-2006

Completed 08-04-2006

(unbeaded) Water Well Constructor Certiffeation

I certify that the work I performed on the construction, deepening alteration, of abandonment of this well is in complianse with Oregon water supply well construction standards. Materials used and information reported above are true to the best of my knowledge and belief.

License Number Date

Pasword: (if filing electronically)

Signed

(bonded) Water Well Constructor Certification

I accept responsibility for the construction, deepening, alieration, of abandonmer work performed on this well during the construction dates reported above. All work performod during this time is in compliance with Oregon water supply well construction standards. This report is true to the best of my knowledge and belief.

Lictnse Number 1293 Date 08-21-2006

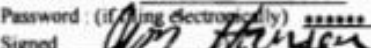

Signed 1 in

PavTMENT 
$\because$

WATER SUPPLY WELL RE.PORT -

continuation page
WASC 51497

WELL L.D. "L 699066380

START CARD \# 175030

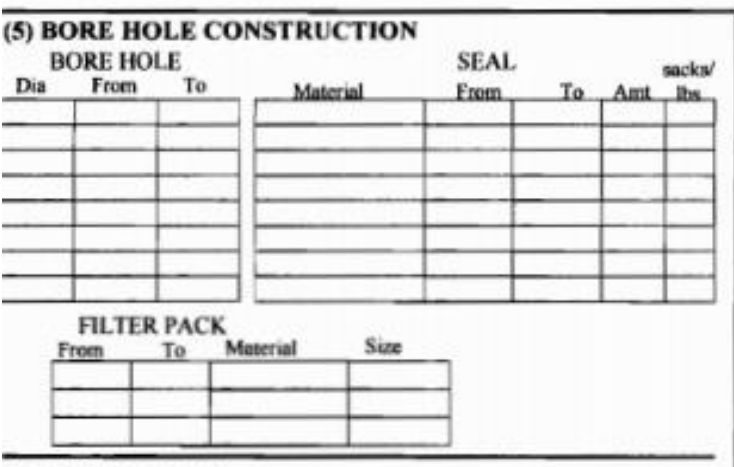

(6) CASING/LINER

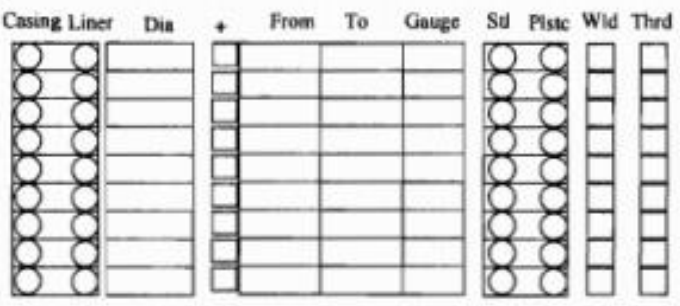

\section{(7) PERFORATIONS/SCREENS}

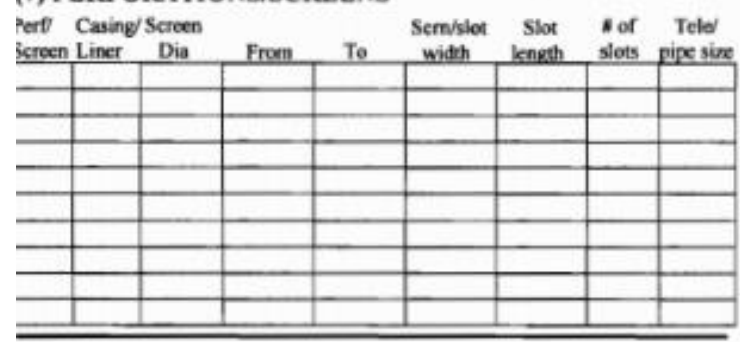

(8) WELL TESTS: Minimum testing time is 1 hour

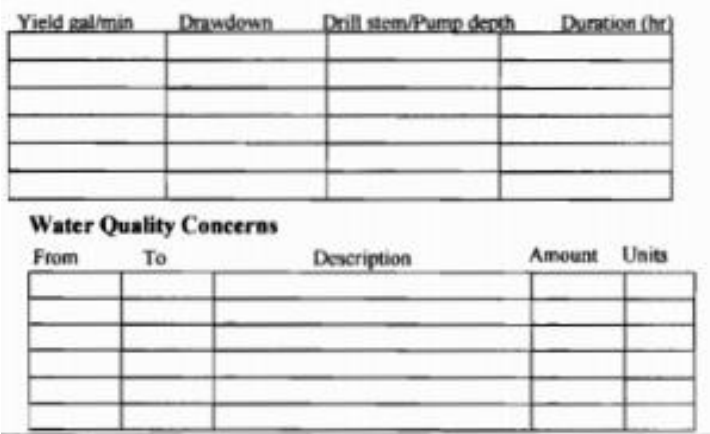

Figure B26: WASC 51497 page 2
(10) STATIC WATER LEVEL

Water Beariag Zones

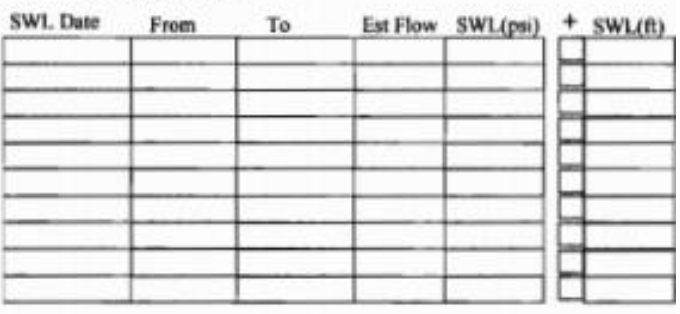

(11) WELL LOG

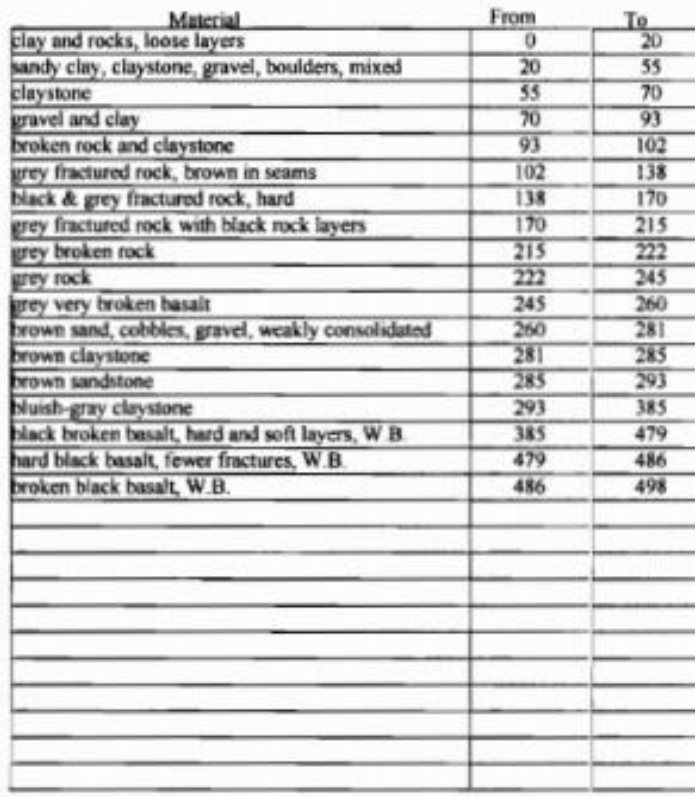

Comments/Remarks

9.5 of $20^{*}$ pipe was left in hole, it was inadveneatly cemented in

Well Test. Well was tested (a) 300gpm for 24 hours. 9psi after 24 hours.

To prevent water from flowing up the $6^{*}$ liner during installation, a $6^{*}$ drillabk

plug was installed at the top of the perforations. $A \mathrm{~W}^{\prime}$ diameter ring was

weided in place to prevent the plug from puahing up the pipe as the liner was

put in place. This plug was pushed to the botlom and drilled up while drilling

hole from $495^{\prime}$ to $498^{\prime}$ using a $5-1 / 4^{\prime \prime}$ bit.

\section{REGEMER}




$$
\text { *. }
$$

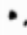

WATER SUPPLY WELL REPORT -

continuation page

Map of well

\section{WASC 51497}

WELL I.D. \#L6690 66330 START CARD \# 175038

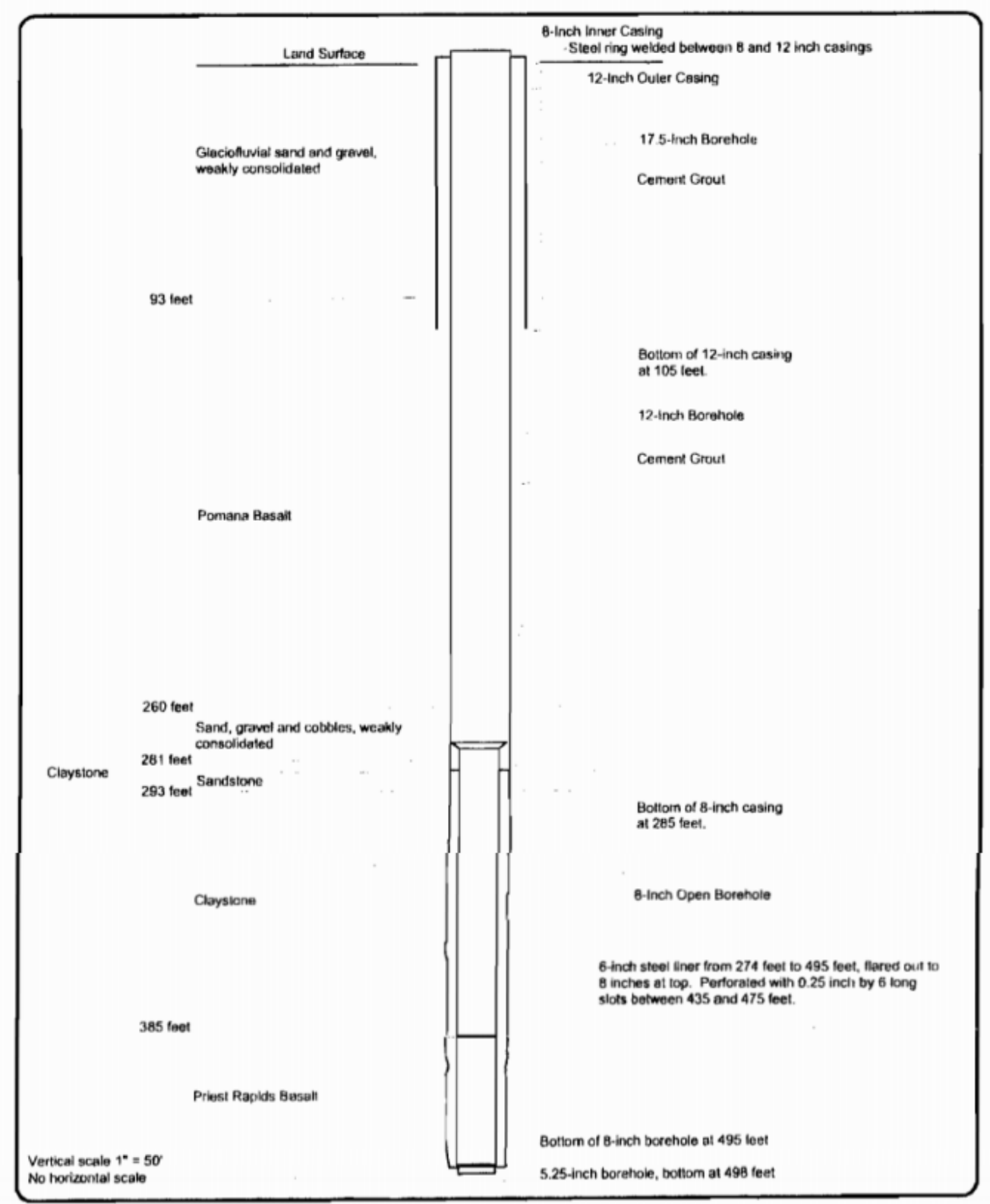

Figure B27: WASC 51497 page 3 
STATE OF OREGON

WATER SUPPLY WELL REPORT

(as required by ORS $\$ 37.765$ \& ONR 690-205-0210)
WASC $\mathbf{5 1 7 7 8}$

Page 1 of 1

05-13-2010
WELL LABEL \# L 77324

START CARD \# 198497

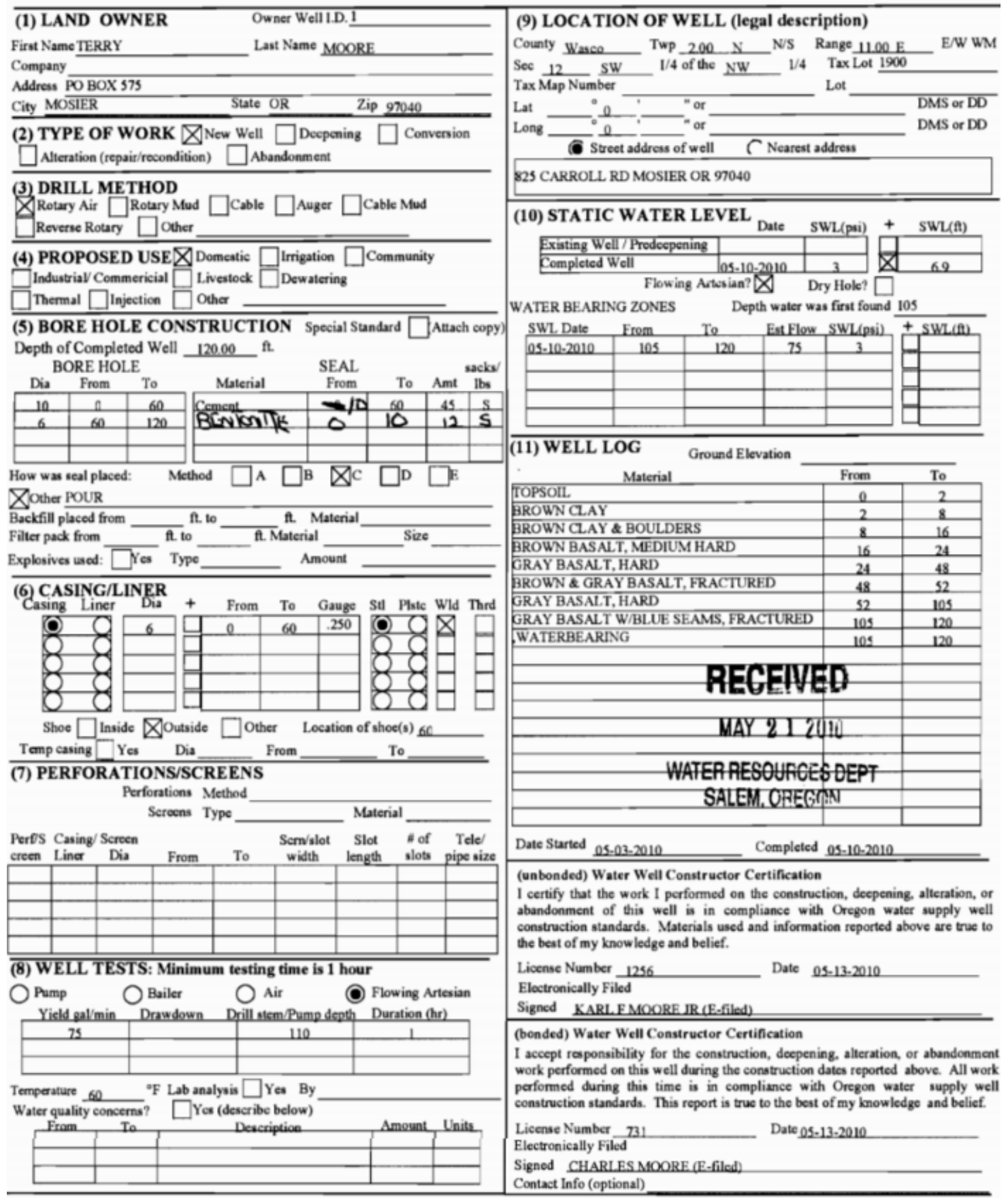

Figure B28: WASC 51778 
STATE OF OREGON

WATER SUPPLY WELL REPORT

(as required by ORS 537.765 \& OAR 690-205.0210)
$12-12-2010$
WELL LABEL $\#$ L 98283

START CARD H 1010920

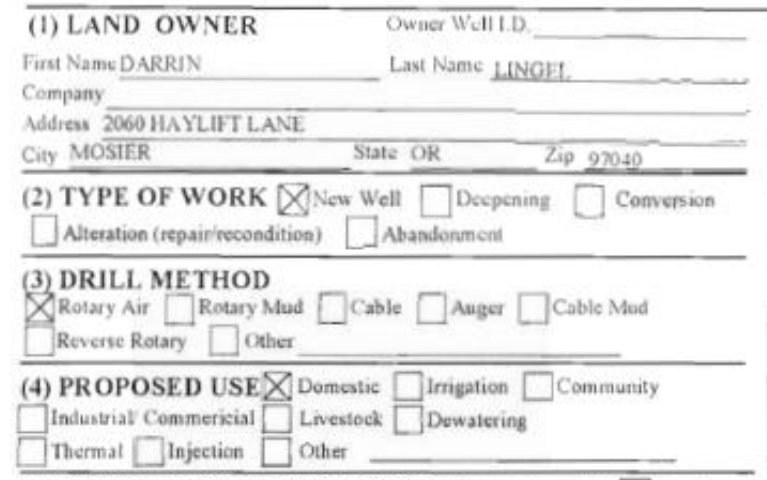

(5) BORE HOLE CONSTRUCTION Spceial Standard $\square$ Anach copy Depth of Completed Well 885.00 it

\begin{tabular}{l} 
BORE HOLE \\
\begin{tabular}{|c|c|c|}
\hline Dia & From & To \\
\hline 10 & 0 & 660 \\
\hline 8 & 660 & 885 \\
\hline & & \\
\hline
\end{tabular} \\
\hline
\end{tabular}

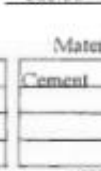

Hew was scal placed

Dother

Backfill placed from

Filter pack from Method

Material

SEAL

Explosives used:

fi. to A. Material

n. Material

Amount
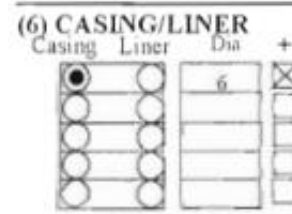

+ rrom To

To Gaspe s

sacker

Shoe $\square$ Inside \اoutside

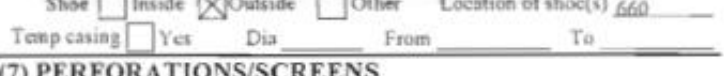

(7) PERFORATIONS/SCREENS

Perforations Method

Screens Type

Perfis Casing/Screen Scrnslot Slot Hof Tele

crces Liner Dia from To width leagdh slots pipesize

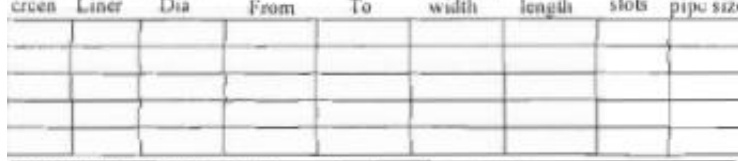

(8) WEL.L TESTS: Minimum testing time is 1 hour

Pump $\bigcirc$ Banler Air $\bigcirc$ flowing Antevian

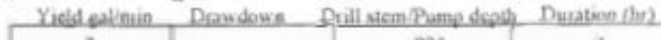

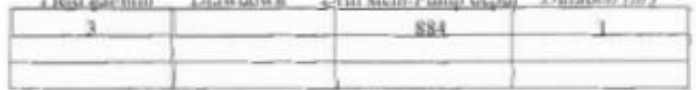

Temperatur $61 \quad$ "F Labanalysis $\square$ Yes By

Water qualify concerns? Yes (describe below)

\section{(9) LOCATION OF WELL (legal description)}

Conaty J Jasce Twp 200 iV N/S Range $1200 \mathrm{E}$ EW Wh See $16 \quad$ SW 1/4 of ths NW 1/4 Tax Lot 1900

Tax Mtap Number Lot

Lat

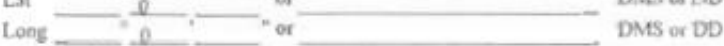

Strout address of wull C Nearest addron

po60 HA NLFT LANE

(10) STATIC WATER LEVEI

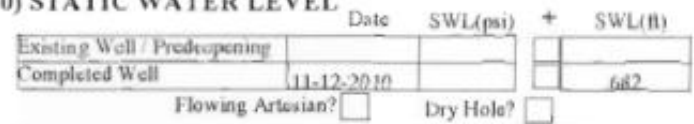

Flowing Artesian? $\square$ Dry Hole? Depth water was first found 622

\begin{tabular}{|c|c|c|c|c|}
\hline \multicolumn{2}{|c|}{ VATER BEARUNG ZONES } & \multicolumn{3}{|c|}{ Depth water was first found 622} \\
\hline & Frem. & $T_{0}$ & EstFlons SW/(psi) & + SWL(a) \\
\hline $09.26-2010$ & 622 & 636 & \begin{tabular}{l|l}
1 & -1
\end{tabular} & \begin{tabular}{|l|l|} 
& 410 \\
\end{tabular} \\
\hline $10-04 \cdot 2010$ & 822 & nas & & $6 \times 2$ \\
\hline & & & & \\
\hline & & & & \\
\hline
\end{tabular}

\section{(11) WELL LOG Ground Elevation}

\begin{tabular}{|c|c|c|}
\hline \\
\hline Matcrial & Froen & To \\
\hline CLAY TAN & 0 & 21 \\
\hline SANDSTONE HURD TAN & 21 & 65 \\
\hline CIAYTAN & 65 & 71 \\
\hline SANDSTONECLAY TAN & 22 & 182 \\
\hline SANDSTONE FWE HARDCLAY JAX & 182 & 107 \\
\hline BASALT HARD GKAY & 102 & 622 \\
\hline BASALI FKAC SOFT GRAY W:B & 622 & 634 \\
\hline BASALT HARD GRNY & 636 & 823 \\
\hline BASAIT TRAC W/B & $\$ 223$ & 883 \\
\hline & & \\
\hline & & \\
\hline & & \\
\hline & & \\
\hline & & \\
\hline & & \\
\hline & & \\
\hline & & \\
\hline
\end{tabular}

Date Started 08-07-2019___ Completed 11-12-2010

(unbended) Water Well Coastructor Certification

I certify that the work I performed on tie construction, decpening a teration, wi abandonment of this well is in compliance with Oregos water supply well construction standards. Materials used and information reported alsove are true to the best of my knowhidge and belief.

Liecase Numbur Datc

Electronically Filed

Signed

(bonded) Water Well Constructer Centilication

I aceept roponsibiliny for the construction. derpening, alteration, or abundonmen work performed on this wcll during the construction dates reportud above. All woek performed during this time is ia compliance with Oregon water sapply wol construction standards. This report is truc to the best of my linowiedge and belief.

Figure B29: WASC 51831 